\title{
Development of Methods to Predict Agglomeration and Deposition in Fluidized-Bed Combustion Systems (FBCS)
}

Topical Report

Michael D. Mann Ann K. Henderson Michael L. Swanson

Sean E. Allan

February 1996

Work Performed Under Contract No:: DE-FC21-93MC30098

For

U.S. Department of Energy

Office of Fossil Energy

Morgantown Energy Technology Center

Morgantown, West Virginia

By

University of North Dakota

Energy \& Environmental Research Center

Grand Forks, North Dakota 


\section{DISCLAIMER}

This report was prepared as an account of work sponsored by an agency of the United States Government. Neither the United States Government nor any agency thereof, nor any of their employees, makes any warranty, express or implied, or assumes any legal liability or responsibility for the accuracy, completeness, or usefulness of any information, apparatus, product, or process disclosed, or represents that its use would not infringe privately owned rights. Reference herein to any specific commercial product, process, or service by trade name, trademark, manufacturer, or otherwise does not necessarily constitute or imply its endorsement, recommendation, or favoring by the United States Government or any agency thereof. The views and opinions of authors expressed herein do not necessarily state or reflect those of the United States Government or any agency thereof.

Available to the public from the National Technical Information Service, U.S. Department of Commerce, 5285 Port Royal Road, Springfield, VA 22161; phone orders accepted at (703) 487-4650. 


\section{DISCLAIMER}

Portions of this document may be illegible in electronic image products. Images are produced from the best available original document. 


\title{
Development of Methods to Predict Agglomeration and Deposition in Fluidized-Bed Combustion Systems (FBCS)
}

\section{Topical Report}

Michael D. Mann

Ann K. Henderson

Michael L. Swanson

Sean E. Allan

Work Performed Under Contract No.: DE-FC21-93MC30098

\author{
For \\ U.S. Department of Energy \\ Office of Fossil Energy \\ Morgantown Energy Technology Center \\ P.O. Box 880 \\ Morgantown, West Virginia 26507-0880
}

By

University of North Dakota

Energy \& Environmental Research Center

P.O. Box 9018

Grand Forks, North Dakota 58202-9018

February 1996 


\section{DEVELOPMENT OF METHODS TO PREDICT AGGLOMERATION AND DEPOSITION IN FBCS}

\section{EXECUTIVE SUMMARY}

The successful design and operation of a fluidized-bed combustor (FBC) requires the ability to control and mitigate ash-related problems. The major ash-related problems in fluidized-bed combustion are agglomeration of bed material, ash deposition on heat-transfer surfaces, ash deposition on refractory and uncooled surfaces, corrosion, and erosion. The focus of this program was on the agglomeration and deposition problems in atmospheric bubbling and circulating beds. This three-year, multiclient program was designed to determine the behavior of inorganic components in FBC units using advanced analytical methods coupled with bench-scale combustion experience.

To diagnose and reduce ash-related problems in FBC systems, a comprehensive understanding of the fuel, ash, and system materials properties must be achieved. This understanding requires that the materials be analyzed in detail to assess their chemical and physical characteristics. Effective materials analysis requires appropriate and effective materials-sampling techniques. Because materials sampling must often be undertaken by operations personnel, it is important that a standard sampling method be available. Therefore, a sampling and analysis protocol was developed to aid the operations engineer in providing effective samples for analysis and testing. This protocol is organized to provide a handy reference for those involved with FBC operations. Section 2.0 of this report will specifically address strategies intended to reduce ash-related operational problems.

Full-scale sampling yielded many interesting and useful results. An intensive sampling effort was undertaken at the Montana-Dakota Utilities 80 -MWe bubbling bed facility located at the Heskett Station. Agglomerating tendencies at this unit force a bed turnover approximately every 50 hours. Deposition on the superheater surfaces results in a loss in superheat of over $40^{\circ} \mathrm{F}$ during the course of 4 months. The analysis of the data from the Heskett Station shows conclusively that certain coal ashes tend to form deposits in the FBC. The mechanisms of adherence and growth appear to be via a molten sulfate matrix, through the fluxing action of sodium with the calcium sulfate matrix. The bed material plays no significant role in the deposition matrix. The agglomeration, on the other hand, shows a definite interaction between bed material and ash, with certain minerals in the bed contributing more to agglomeration than others. Details of the proposed mechanisms are provided in this report.

Ten different fuels have been tested in the Energy \& Environmental Research Center (EERC) 1-MWth circulating fluidized-bed combustor (CFBC) under separate programs. The tendency for each of the fuels to form deposits and agglomerates in the CFBC pilot plant was evaluated as a part of this program. Agglomeration was less prevalent than deposition and was noted only for the Center lignite and petroleum cokes. The agglomeration for the Center lignite was undoubtedly related to the sodium content in the lignite. It is less clear what initiated the agglomeration in the petroleum coke cases; however, it is speculated that local reducing conditions provide the opportunity for low-temperature eutectics of either $\mathrm{CaS}$ and $\mathrm{CaSO}_{4}$ or possibly $\mathrm{CaSO}_{4}$ and $\mathrm{V}_{2} \mathrm{O}_{5}$ to form. 
Some deposits were formed during firing of most of the test fuels. Deposition occurred on the refractory surfaces of the primary cyclone and downcomer and on the ash-fouling probes that were designed to simulate the leading edge of the convective pass. Generally speaking, the deposits consisted of fine-grained (1- to 10-micron) calcium sulfate. In many cases, the deposits were soft and would slough off of the surfaces because of their own weight. A notable difference was the degree of sulfation of the deposited material. In all cases, the deposit was more sulfated than the ash collected in the secondary cyclone. Deposits formed when firing high-sulfur fuels were more sulfated than those from low-sulfur fuels. It was also observed that the more sulfated deposits tended to show higher strength than the less sulfated deposits.

The following hypothesis, along with some observations and comments, is provided on the deposit formation. The mechanisms of formation for the thick back side deposits are likely eddy impaction and thermophoresis. Mostly small particles of less than 10 microns follow the stream lines around the tubes and impact as a result of eddy currents. It appears that the primary component of the deposit is partially sulfated limestone. The cementing agent loosely holding the deposit particles together appears to be partially sulfated limestone that continues to become more fully sulfated over time, resulting in continued particle growth. The deposit probably reaches an equilibrium size, at which time it falls off under its own weight. It does not seem that the large deposits on the back side of the probes would represent a serious fouling problem. They are relatively soft, although they could become a hard deposit if permitted to stay on the boiler tubes for an extended period of time. It would seem prudent to at least leave room in the higher-temperature regions of the convective pass for the installation of sootblowing capabilities. The hard deposits on the front side of the probes would be more difficult to remove.

Parametric testing on a bench-scale reactor was performed. A high-sodium lignite was used to generate significant changes in bed chemistry, ranging from coated bed material and particle sticking to a sintered mass causing defluidization, in a relatively short period of time. The effects and interactions of temperature and excess air have been studied. The bench-scale reaction provides a useful tool to study bed chemistry in FBC and can be used to predict agglomerating tendencies.

A laboratory sintering apparatus was used to help understand the chemical and physical characteristics of the coal ash and bed material that lead to agglomeration. Ash generated from the $\mathrm{FBC}$ of various coals was tested, with shrinkage (sintering) apparent at $1600^{\circ} \mathrm{F}$ for a highly agglomerating Buelah lignite. Other tests demonstrated the importance of the form of the sodium, by showing an independence of bed sodium concentration and sintering temperature. Fundamental evaluations also showed the existence of a temperature window $\left(1450^{\circ}\right.$ to $\left.1550^{\circ} \mathrm{F}\right)$ where agglomeration did not readily occur. The influence of $\mathrm{SO}_{2}$ on agglomeration was also demonstrated, with the formation of sulfates being a critical step in the agglomeration process.

Factors which enhance the formation of agglomerates include local reducing conditions in the bed; high temperature, particularly at the surface of coal particles, which approaches the melting temperature of various mineral phases; increased pressure, which speeds reaction rates as a result of increased partial pressure of oxygen; and the presence of a fluxing agent, such as sodium or calcium, which lowers the melting point of certain silicate-based clays. The lignites burned at the Heskett Station and in the bench-scale reactor showed plastic characteristics, 
which are the probable cause of egg-type agglomerates. Detailed mechanisms of this complete process are provided in the report.

Methods to predict the effect of coal properties and operating conditions on deposition have been developed for conventional coal-fired systems. Existing models and indices were adapted to predict deposition potential in fluidized-bed systems. The emphasis is on the prediction of methods of ash formation, partitioning of ash out of the bed, and deposition and deposit strength in the convective pass. The propensity for agglomeration can be predicted based on ash properties using a code developed during the project or by firing the fuel in the bench-scale reactor. 


\section{TABLE OF CONTENTS}

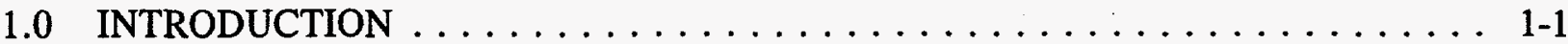

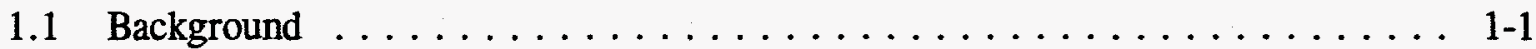

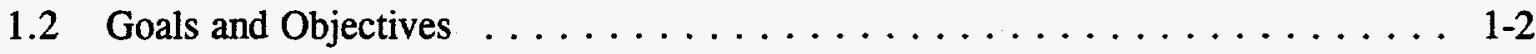

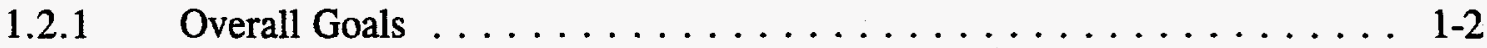

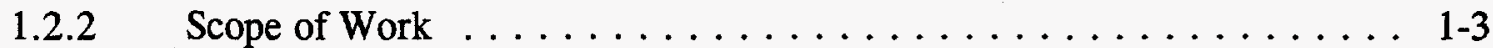

1.3 Definition of Agglomeration . . . . . . . . . . . . . . . . 1-4

1.4 Definition of Low-Temperature Deposition $\ldots \ldots \ldots \ldots \ldots \ldots \ldots \ldots$. $\ldots \ldots$

2.0 DEVELOPMENT OF SAMPLING AND ANALYTICAL TECHNIQUES $\ldots \ldots \ldots$ 2-1

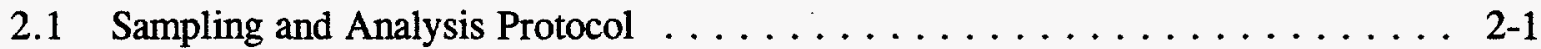

2.2 Development of Methods for Investigating Bed Particle Coating and

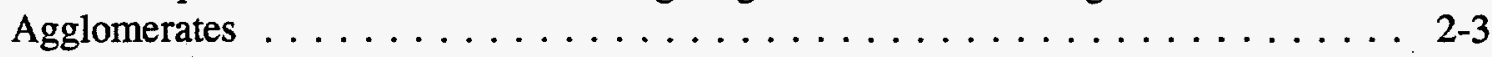

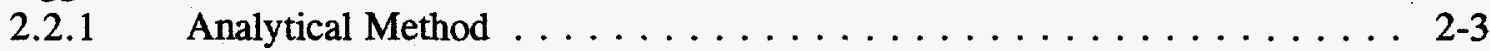

2.2.2 Methods Demonstration $\ldots \ldots \ldots \ldots \ldots \ldots \ldots \ldots \ldots .2-4$

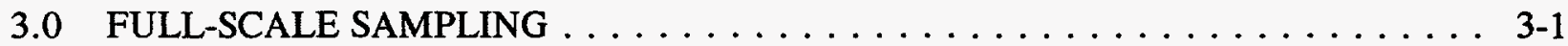

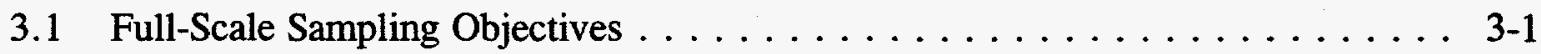

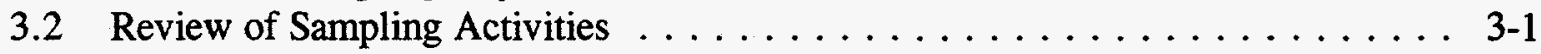

3.2.1 Montana-Dakota Utilities $\ldots \ldots \ldots \ldots \ldots \ldots \ldots \ldots \ldots \ldots$ 3-1

3.2.2 Northern States Power Company . . . . . . . . . . . . 3-4

3.3 Results of Bulk Chemistry Analyses . . . . . . . . . . . . . . . . 3-4

3.3.1 Montana-Dakota Utilities . . . . . . . . . . . . . . . . . 3-4

3.3.2 Northern States Power Company . . . . . . . . . . . . . . 3-13

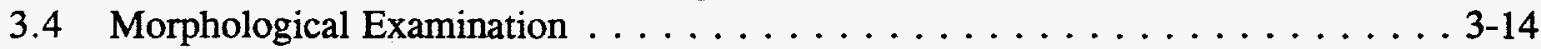

3.4.1 Montana-Dakota Utilities $\ldots \ldots \ldots \ldots \ldots \ldots \ldots \ldots \ldots \ldots .14$

3.4.2 Northern States Power Company . . . . . . . . . . . . . 3-16

4.0 PILOT-SCALE TESTING AT THE EERC $\ldots \ldots \ldots \ldots \ldots \ldots \ldots \ldots \ldots$ 4-1

4.1 Equipment Used and Test Conditions $\ldots \ldots \ldots \ldots \ldots \ldots \ldots \ldots \ldots$ 4-1

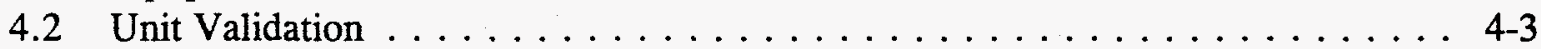

4.3 Powder River Testing $\ldots \ldots \ldots \ldots \ldots \ldots \ldots \ldots \ldots \ldots \ldots \ldots .4 .4$

4.4 Center North Dakota Lignite $\ldots \ldots \ldots \ldots \ldots \ldots \ldots \ldots \ldots \ldots .4 .6 \ldots$

4.5 Mae Moh Thailand Lignite $\ldots \ldots \ldots \ldots \ldots \ldots \ldots \ldots \ldots \ldots .7$

4.6 Delayed Coke $\ldots \ldots \ldots \ldots \ldots \ldots \ldots \ldots \ldots \ldots \ldots \ldots \ldots .4 .10$

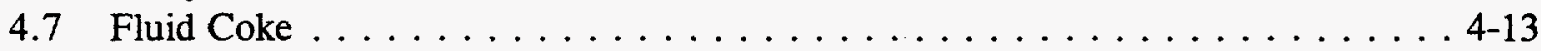

4.8 Dried Municipal Sewage Sludge $\ldots \ldots \ldots \ldots \ldots \ldots \ldots \ldots \ldots \ldots$. $\ldots \ldots \ldots$

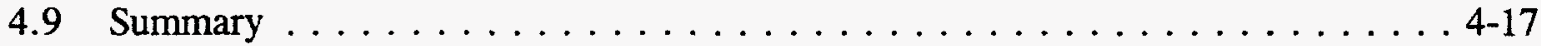

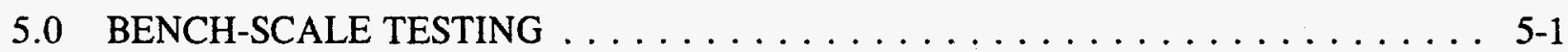

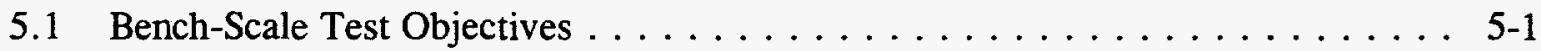

5.2 Description of Pressurized Fluidized-Bed Reactor . . . . . . . . . . . 5-1

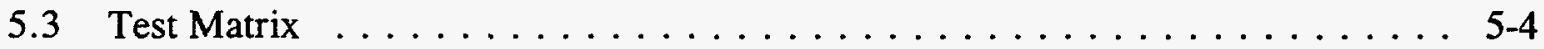

Continued ... 


\section{TABLE OF CONTENTS (continued)}

5.4 Results from Bench-Scale Tests . . . . . . . . . . . . . . . . . 5-5

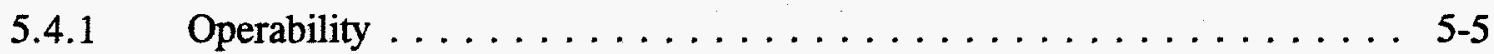

$5.4 .2 \quad$ Agglomeration and Deposition Tendencies $\ldots \ldots \ldots \ldots \ldots$

$5.4 .3 \quad$ Bulk Chemistry . . . . . . . . . . . . . . . . . 5-13

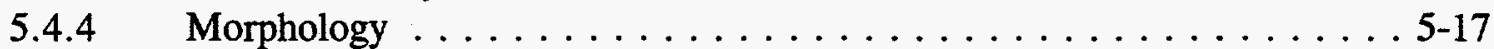

$5.4 .5 \quad$ Validation With Full-Scale Data $\ldots \ldots \ldots \ldots \ldots \ldots \ldots$

6.0 FUNDAMENTAL STUDIES $\ldots \ldots \ldots \ldots \ldots \ldots \ldots \ldots \ldots \ldots \ldots \ldots$

7.0 FLUIDIZED-BED AGGLOMERATION AND DEPOSITION MECHANISMS $\ldots \ldots$. $7-1$

7.1 Agglomeration Mechanisms . . . . . . . . . . . . . . . . $7-1$

7.1.1 Stage 1 - Coating of Bed Particles with Ash $\ldots \ldots \ldots \ldots \ldots$. . . . . .

7.1.2 Stage $2 \mathrm{~A}-$ Particle-to-Particle Bonding $\ldots \ldots \ldots \ldots \ldots \ldots$. . . . . . . . . . . .

7.1.3 Stage 2B - Deposition of Bed Particles on Coal ........... . 7-4

7.1.4 Stage 3 - Interaction of Ash and Limestone on Coal Surface . . . . . . 7-5

7.1.5 Stage 4 - Formation of a Melt on the Coal Surface .......... 7-6

7.1.6 Stage 5 - Coal Burnout Leaving Sintered Egg $\ldots \ldots \ldots \ldots \ldots \ldots$

7.1.7 Alternative Mechanism - High-Temperature Agglomeration . . . . . . 7-7

7.1.8 Factors Enhancing Agglomerate Formation . . . . . . . . . . 7-7

7.2 Ash Formation and Boiler Tube Fouling in Fluidized-Bed Combustion . . . . . 7-8

8.0 PREDICTING AGGLOMERATION IN FBCS $\ldots \ldots \ldots \ldots \ldots \ldots \ldots \ldots \ldots \ldots \ldots . \ldots$.

8.1 Quantifying Melting Temperatures on a Microscale $\ldots \ldots \ldots \ldots \ldots \ldots \ldots \ldots$ 8-1

8.2 FBCSUL Model Assumptions $\ldots \ldots \ldots \ldots \ldots \ldots \ldots \ldots \ldots \ldots \ldots \ldots \ldots \ldots$

8.3 FBCSUL Applications $\ldots \ldots \ldots \ldots \ldots \ldots \ldots \ldots \ldots \ldots \ldots \ldots \ldots \ldots \ldots \ldots$

8.4 Selection of Ash for FBCSUL Analysis $\ldots \ldots \ldots \ldots \ldots \ldots \ldots \ldots \ldots \ldots \ldots$. $\ldots \ldots \ldots$

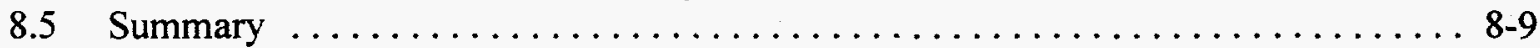

VARIABLE DEFINITION LIST $\ldots \ldots \ldots \ldots \ldots \ldots \ldots \ldots \ldots \ldots \ldots \ldots \ldots$

9.0 PREDICTING DEPOSITION IN FBCS . . . . . . . . . . . . . . . 9-1

9.1 Fluidized-Bed Combustion Deposition Model . . . . . . . . . . . . . . . . 9-1

9.2 Ash Formation Algorithms . . . . . . . . . . . . . . . . . . 9-1

9.3 Ash Formation Results $\ldots \ldots \ldots \ldots \ldots \ldots \ldots \ldots \ldots \ldots \ldots . \ldots \ldots \ldots$

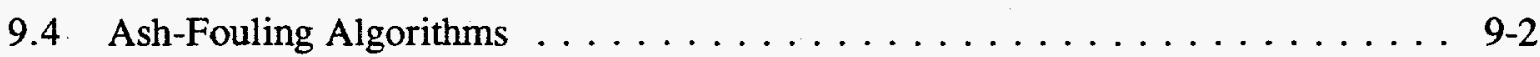

9.4.1 Deposit Growth . . . . . . . . . . . . . . . . . $9-3$

$9.4 .2 \quad$ Strength Development . . . . . . . . . . . . . . . . 9-5

9.4.3 Thermal Properties . . . . . . . . . . . . . . . . . . 9-7

$9.4 .4 \quad$ Deposit Removal . . . . . . . . . . . . . . . . . . . $9-8$

9.5 Fouling Algorithms Results . . . . . . . . . . . . . . . . 9-9

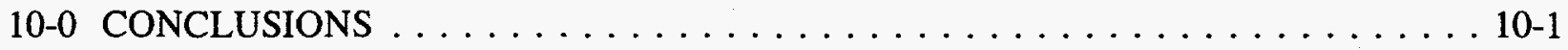

Continued ... 
TABLE OF CONTENTS (continued)

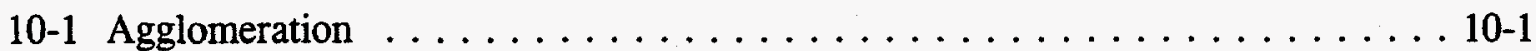

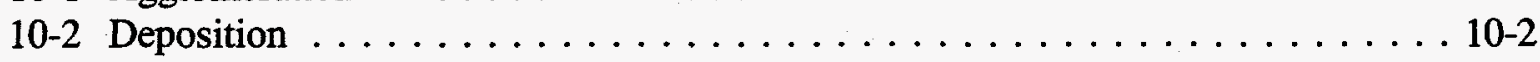

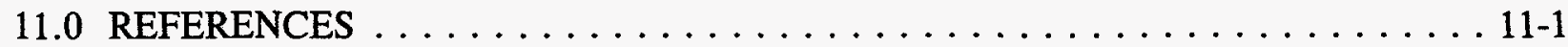




\section{LIST OF FIGURES}

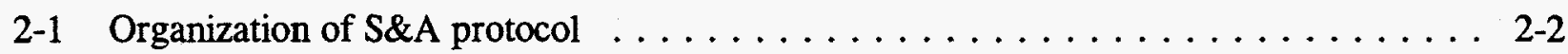

2-2 Backscattered electron image of agglomerates $\ldots \ldots \ldots \ldots \ldots \ldots \ldots$

2-3 Backscattered electron image of an agglomerate $\ldots \ldots \ldots \ldots \ldots \ldots \ldots \ldots \ldots$

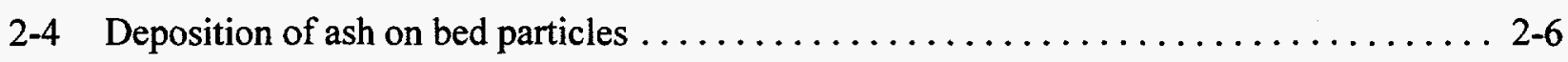

2-5 Size distribution of the sandstone bed materials $\ldots \ldots \ldots \ldots \ldots \ldots \ldots \ldots \ldots \ldots$

2-6 Amount of ash deposited as coating on bed particles $\ldots \ldots \ldots \ldots \ldots \ldots \ldots \ldots \ldots$

2-7 Major elemental chemical composition of ash coatings $\ldots \ldots \ldots \ldots \ldots \ldots \ldots \ldots$

2-8 Ash coatings on quartz and plagioclase $\ldots \ldots \ldots \ldots \ldots \ldots \ldots \ldots \ldots \ldots \ldots \ldots$

3-1 Location of end-of-test deposit samples collected by EERC personnel on

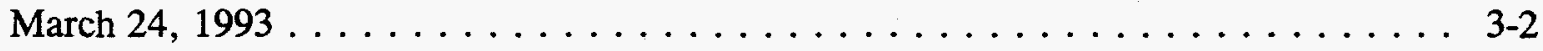

3-2 Location of run-time samples collected by MDU personnel on March 3, $1993 \ldots$. . . . . 3-2

3-3 Comparison of deposits collected from the Heskett Station . . . . . . . . . . 3-8

3-4 Comparison of run-time samples collected from the Heskett Station . . . . . . . . . 3-8

3-5 Comparison of deposit and coal ash chemistry for various locations in the Heskett Station . . . . . . . . . . . . . . . . . . . . 3-9

3-6 Comparison of deposit and fly ash chemistry from the Heskett Station . . . . . . . . 3-9

3-7. Comparison of run-time samples with sampling location for the Heskett Station . . . . . 3-11

3-8 Comparison of bed material and bed deposit chemistry from the Heskett Station . . . 3-11

3-9 Comparison of bed material and bed deposit chemistry from the Black Dog Station . . . 3-14

3-10 Line scan analysis of a coated bed material from the Heskett Station . . . . . . . . 3-15

3-11 Sodium line scan for a Black Dog bed material particle $\ldots \ldots \ldots \ldots \ldots$. . . . . .

4-1 Schematic of EERC $1-M W_{\text {th }}$ CFBC pilot plant $\ldots \ldots \ldots \ldots \ldots \ldots$

Continued ... 


\section{LIST OF FIGURES (continued)}

4-2 Size distribution of baghouse ash from the Nucla Power Station and the Pyropower and EERC pilot plants . . . . . . . . . . . . . . . . . . . 4-3

4-3 Probe deposits remaining in ash-fouling duct at the end of Powder River test . . . . . 4-4

4-4 Photomicrographs of outer portion of probe deposit from Powder River test . . . . . . 4-5

4-5 Photomicrograph of inner portion of probe deposit from Powder River test $\ldots . . .44-5$

4-6 Convective pass ash-fouling probes after test with Thailand lignite $\ldots \ldots \ldots$. . . 4-8

4-7 Deposit formed on top of the shell-and-tube heat exchanger during the second week of testing using Thailand lignite $\ldots \ldots \ldots \ldots \ldots \ldots \ldots$

4-8 SEM micrograph of the deposit from the shell-and-tube heat exchanger:

a) magnified 500 times, b) magnified 5000 times $\ldots \ldots \ldots \ldots \ldots$. . . . . . . . .

4-9 Close-up of the agglomerates from EHX during delayed coke test $\ldots \ldots \ldots$. . . $\ldots$ 11

4-10 Ash coating on downstream side probe formed during delayed coke test . . . . . . 4-11

4-11 Upstream side probe after delayed coke test . . . . . . . . . . . . . 4-12

4-12 Deposits formed on the regenerator distributor plate when

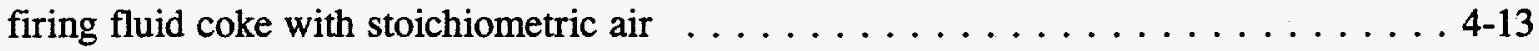

4-13 Deposits formed on the ash-fouling probes during the DMSS test . . . . . . . 4-14

4-14 East ash-fouling probe temperatures during the second day of DMSS testing. . . . . . 4-15

4-15 East ash-fouling probe temperatures during the fourth day of DMSS testing $\ldots \ldots$. . 4-16

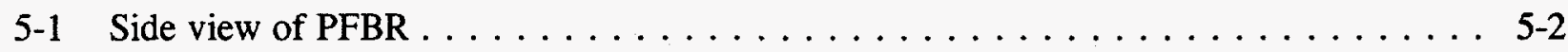

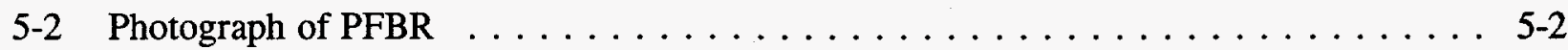

5-3 Photograph of PFBR in external heat jacket with auxiliaries installed . . . . . . . . 5-3

5-4 Temperature distribution over time for Test KR2-1195 . . . . . . . . . . . 5-12

5-5 Temperature distribution over time for Test KR2-1295 . . . . . . . . . . . . 5-12

Continued ... 


\section{LIST OF FIGURES (continued)}

5-6 Temperature distribution for three bench-scale tests $\ldots \ldots \ldots \ldots \ldots \ldots \ldots$ 5-13

5-8 Chemical composition of bed material over time for Test KR1-0295 . . . . . . . 5-14

5-7 Chemical composition of bed material over time for Test KR1-0195 . . . . . . . 5-14

5-9 Chemical composition of bed material over time for Test KR1-0595 . . . . . . 5-15

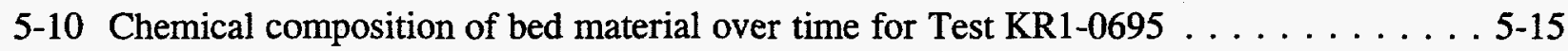

5-11 Chemical composition of bed material over time for Test KR2-2295 . . . . . . . 5-16

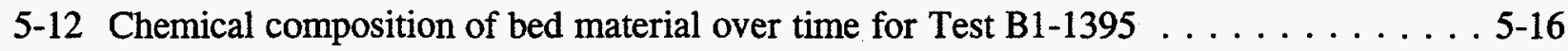

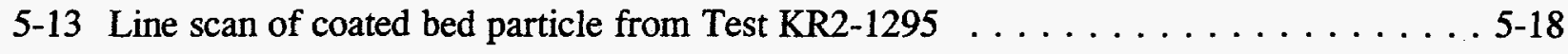

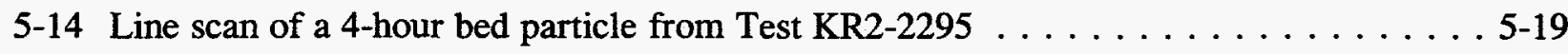

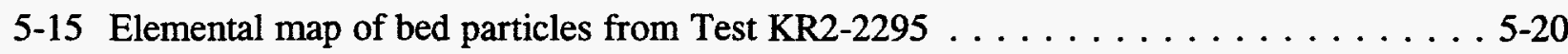

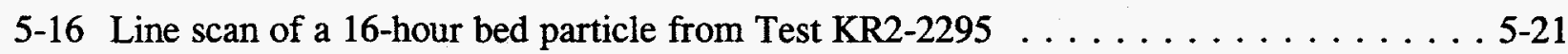

6-1 Schematic of the sintering test apparatus $\ldots \ldots \ldots \ldots \ldots \ldots \ldots \ldots \ldots \ldots \ldots \ldots .6 \ldots$

6-2 Displacement as a function of temperature using sintering apparatus $\ldots \ldots \ldots \ldots$ 6-2

6-3 Sinter temperature of ground bulk bed materials as a function of $\mathrm{Na}_{2} \mathrm{O} \ldots \ldots \ldots \ldots$ 6-3

6-4 Shrinkage sintering characteristics of bed material from an agglomerating run . . . . . 6-5

6-5 Distribution of liquid phases as a function of deposit temperature $\ldots \ldots \ldots \ldots$ 6-6

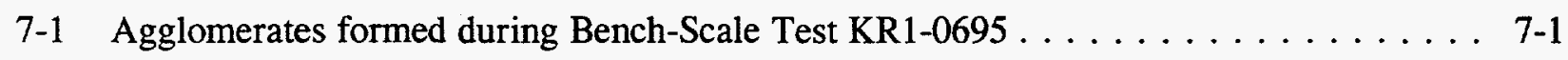

7-2 Egg-type agglomerates collected from NSP's Black Dog Station . . . . . . . 7-2

7-3 Sintered agglomerates formed during Bench-Scale Test KR1-0395 $\ldots \ldots \ldots \ldots$ 7-3

7-4 Pictorial reproduction of the mechanisms of ash formation and bed material agglomeration in fluidized-bed combustion $\ldots \ldots \ldots \ldots \ldots \ldots \ldots \ldots \ldots$

7-5 Bed material stuck to the surface of a particle, formed during bench-scale test KR1-0295 . . . . . . . . . . . . . . . . . . . 7-5

Continued ... 


\section{LIST OF FIGURES (continued)}

7-6 SEM micrograph showing the plasticity of coal particles $\ldots \ldots \ldots \ldots \ldots \ldots$ 7-6

7-7 Ash formation and fouling in fluidized-bed combustion $\ldots \ldots \ldots \ldots \ldots \ldots .7 .19$

8-1 Phase diagram for the alkaline sulfate system, including sodium, calcium, and magnesium . . . . . . . . . . . . . . .

8-2 Distribution of alkali sulfate points from a Center lignite baghouse ash generated in

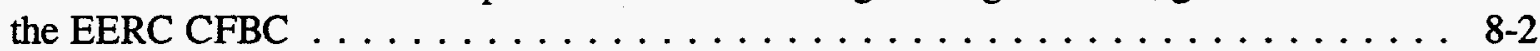

8-3 Distribution of alkali sulfate points from a fluid coke baghouse ash generated in the EERC CFBC

8-4 Comparison of FBCSUL output based on the alkaline components of the baghouse ash for four test coals fired on the EERC CFBC $\ldots \ldots \ldots \ldots \ldots \ldots \ldots \ldots$. 4

8-5 Comparison of FBCSUL output based on all components of the baghouse ash for four test coals fired on the EERC CFBC

8-6 Comparison of FBCSUL output based on the alkaline components of the downcomer ash for the four test coals fired on the EERC CFBC $\ldots \ldots \ldots \ldots \ldots . \ldots .6$

8-7 Comparison of FBCSUL output based on all components of the downcomer ash for four test coals fired on the EERC CFBC

8-9 Impact of the ash origin on the FBCSUL output based on all the components $\ldots \ldots$ 8-9

9-1 Comparison of measured, predicted, sorbent, and original coal components for ash collected in a cyclone

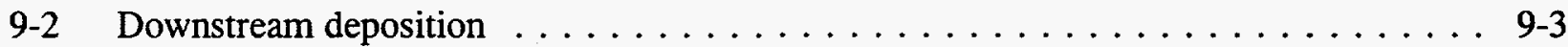

9-3 Components of the deposit growth model $\ldots \ldots \ldots \ldots \ldots \ldots \ldots \ldots$ 9-5

9-4 Strength development curve $\ldots \ldots \ldots \ldots \ldots \ldots \ldots \ldots \ldots \ldots \ldots \ldots$ 9-7

9-5 Heat transfer through deposit $\ldots \ldots \ldots \ldots \ldots \ldots \ldots \ldots \ldots \ldots \ldots$ 9-8

9-6 Comparison of upstream and downstream deposit strengths of a Beulah lignite with limestone sorbent added and a Beulah lignite with no sorbent added

Continued . . . 


\section{LIST OF FIGURES (continued)}

9-7 Comparison of upstream and downstream deposit masses for a Beulah lignite fired with and without a limestone sorbent $\ldots \ldots \ldots \ldots \ldots \ldots \ldots \ldots \ldots$

9-8 Comparison of downstream deposit strength for three coals with a sorbent additive using the Heskett boiler configuration . . . . . . . . . . . . . . . 9-12

9-9. Comparison of sootblower effectiveness for Beulah lignite using the Heskett boiler

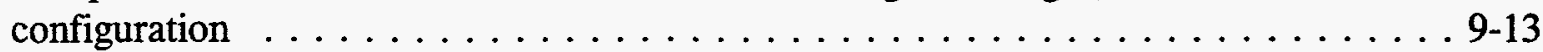




\section{LIST OF TABLES}

2-1 Sodium Contents of the Test Coals $\ldots \ldots \ldots \ldots \ldots \ldots$

2-2 Quantitative Mineralogy of the Sandstone Beds . . . . . . . . . . . . . . 2-6

2-3 Average Enrichment and Depletion Factors for Agglomerate Neck Growths . . . . . . 2-9

3-1 End-of-Test Deposit Samples Collected by EERC Personnel on March 24, 1993 . . . . 3-3

3-2 Run-Time Samples Collected by MDU Personnel on March 3, $1993 \ldots$. . . . . . . . . 3-3

3-3 Proximate and Ultimate Analysis of Beulah Lignite Coal Used at the Heskett Station . . 3-5

3-4 X-Ray Fluorescence Analysis of the Ash from the Beulah Lignite Coal Used at the

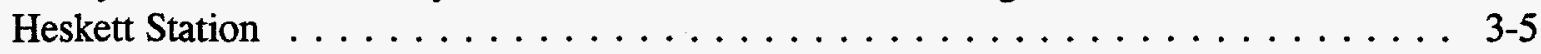

3-5 Summary of CCSEM Results for Heskett Station Beulah Lignite Coal . . . . . . . . . 3-6

3-6 Chemical Fractionation Results of the Beulah Lignite Coal Used at the Heskett Station . 3-6

3-7 XRF/Elemental Analysis of Heskett Station Samples . . . . . . . . . . . . 3-7

3-8 Samples Collected by NSP Personnel . . . . . . . . . . . . . . . 3-13

3-9 Oxide Analysis of Selected Points from Clay-Colored Agglomerate . . . . . . . . 3-18

$4-1$ Fuel Analyses $\ldots \ldots \ldots \ldots \ldots \ldots \ldots \ldots \ldots \ldots \ldots \ldots \ldots \ldots \ldots$

4-2 Results of SEM Analyses Performed on the Ash-Fouling Probe Deposits from the Powder River Test Run . . . . . . . . . . . . . . . . . . . . . 4-6

4-3 Analysis of Deposit from the Shell-and-Tube Heat Exchanger . . . . . . . . . . . 4-10

4-4 Elemental Analysis of Ash and Deposits from DMSS Firing $\ldots \ldots \ldots \ldots$. . . . . 4-16

4-5 Occurrence of Agglomeration When Firing Various Fuels in the EERC CFBC . . . . 4-18

4-6 Occurrence of Deposition When Firing Various Fuels in the EERC CFBC . . . . . . 4-19

5-1 Proposed Screening Matrix for North Dakota Lignite Tests . . . . . . . . . . . . . 5-4

$5-2$ As-Run Test Matrix for North Dakota Lignite $\ldots \ldots \ldots \ldots \ldots \ldots$

5-3 Fuel Analyses for Bench-Scale Tests $\ldots \ldots \ldots \ldots \ldots \ldots \ldots \ldots$

Continued ... 


\section{LIST OF TABLES (continued)}

5-4 Operating Conditions for Bench-Scale Tests . . . . . . . . . . . . . 5-9

5-5 Emissions for Bench-Scale Tests . . . . . . . . . . . . . . . . 5-10

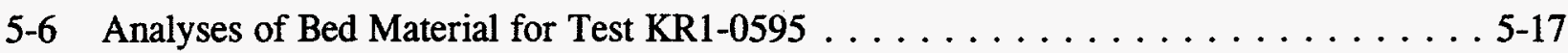

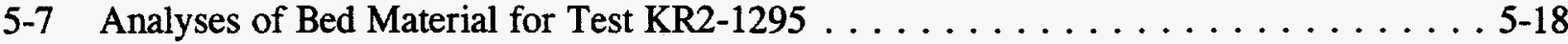

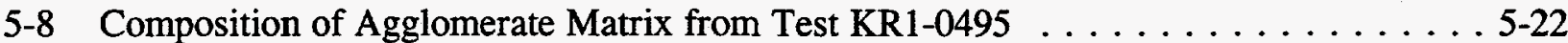

5-9 Chemical Composition of Agglomerate from Test KR1-0695 . . . . . . . . . . 5-22

5-10 Comparison of Chemical Compositions of Bed Material Coating

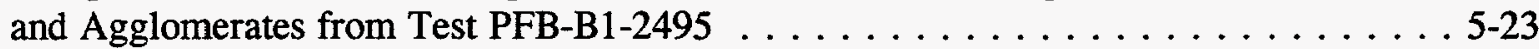

5-11 Comparison of Bulk Analyses at Bench Scale and Full Scale . . . . . . . . . . 5-23

5-12 Comparison of Bed Material Coatings from EERC and Heskett $\ldots \ldots \ldots \ldots$. . . . 5-24

5-13 Analyses of Selected Points from Heskett Agglomerate . . . . . . . . . . . . 5-24

5-14 Analyses of Selected Points from EERC Agglomerate . . . . . . . . . . . . . 5-24

5-15 Comparison of Heskett and EERC Deposits $\ldots \ldots \ldots \ldots \ldots \ldots \ldots \ldots \ldots \ldots$

6-1 Summary of Results Evaluating Agglomeration as a Function of Temperature Using a 2 -in. Bench-Scale FBR . . . . . . . . . . . . . 6-4

8.1 Oxide Composition of Ashes Used for Test Cases $\ldots \ldots \ldots \ldots \ldots \ldots$

8.2 Composition of Ashes Used for Comparison Purposes Converted to a Sulfate System . . 8-8 
1.0

INTRODUCTION 
TABLE OF CONTENTS

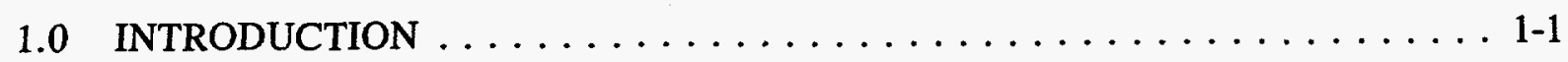

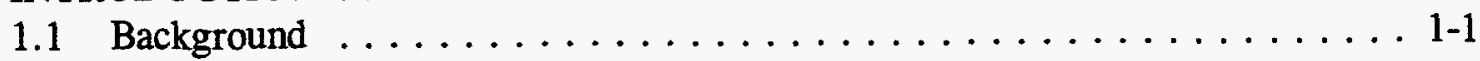

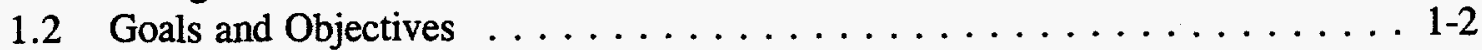

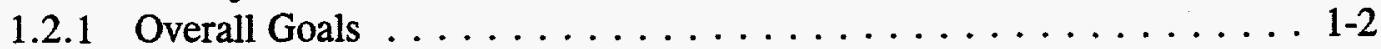

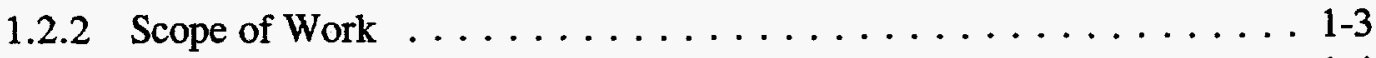

1.3 Definition of Agglomeration . . . . . . . . . . . . . . $1-4$

1.4 Definition of Low-Temperature Deposition . . . . . . . . . . . 1-5 


\section{DEVELOPMENT OF METHODS TO PREDICT AGGLOMERATION AND DEPOSITION IN FBCS}

\subsection{INTRODUCTION}

The successful design and operation of advanced combustion systems require the ability to control and mitigate ash-related problems. The major ash-related problems are slag flow control, slag attack on the refractory, ash deposition on heat-transfer surfaces, corrosion and erosion of equipment materials, and emissions control. These problems are the result of physical and chemical interactions of the fuels, bed materials, and system components. The interactions that take place and ultimately control ash behavior in fluidized-bed combustion (FBC) systems are controlled by the abundance and association of the inorganic components in coal and by the system conditions. Because of the complexity of the materials and processes involved, the design and operations engineer often lacks the information needed to predict ash behavior and reduce ash-related problems.

This document is the final report the Development of Methods to Predict Agglomeration and Deposition in FBCs research project performed by the Energy \& Environmental Research Center (EERC). This three-year, multiclient program has provided information needed to determine the behavior of inorganic components in FBC units using advanced methods of analysis coupled with bench-scale combustion experiments. The major objectives of the program were as follows:

- To develop further our advanced ash and deposit characterization techniques to quantify the effects of the liquid-phase components in terms of agglomerate formation and ash deposits

- To determine the mechanisms of inorganic transformations that lead to bed agglomeration and ash deposition in FBC systems

- To develop a better means to predict the behavior of inorganic components as a function of coal composition, bed material characteristics, and combustion conditions

\subsection{Background}

Even though the FBC operates at a relatively low temperature, a number of potential ashrelated problems exist. For example, deposition on in-bed superheater tubes and supports has been noted for several bubbling FBCs. The amount of deposition is quite variable and dependent upon fuel type. A $40^{\circ} \mathrm{F}$ loss in superheat temperature over a 4-month period at the Montana-Dakota Utilities (MDU) Heskett Station is one example.

In-bed agglomeration, also noted, has been responsible for unscheduled shutdowns. A high bed turnover rate is required by plants such as Heskett. A bed turnover time of approximately 50 hours was originally used at the Heskett plant. Agglomeration of this extent limits the range of fuels that can be burned in the FBC. 
Deposition in the convective pass has also been noted by bubbling-bed FBC users. This deposition results in the loss in steam temperature. Knowing the propensity of certain coal ashes to deposit in the convective section is important for the design of tube spacing and sootblower coverage and schedule.

Similar problems have been identified in circulating fluidized-bed combustion (CFBC) applications. Again, deposition in the convective pass results in a loss in steam temperature. Knowing deposition rates and deposit strengths will be important for designing tube spacing and sootblower coverage and schedule. Another problem inherent to certain fuels in the CFBC is deposition in the cyclone and other cooled surfaces. Some deposits can fall down, plugging drains and loop seals. The deposits can also serve as sites for alkali corrosion.

Agglomeration in the loop seal and bed of the CFBC is responsible for unscheduled shutdowns. As in the bubbling bed, the CFBC requires high bed turnover rates or limitations on bed material selection for control of agglomeration. These problems limit the range of fuels that can be burned in the CFBC.

Other related problems that were not addressed in this program include alkali vapor release in pressurized FBC. This production of alkali vapor results in corrosion and deposition on turbine blades and hot-gas cleanup (alkali removal) requirements.

\subsection{Goals and Objectives}

\subsubsection{Overall Goals}

The overall objective of the program was to advance the knowledge of ash behavior in FBCs so that methods could be generated to predict and, ultimately, mitigate ash-related problems in FBCs. Specific goals are listed below.

- To determine the ash formation mechanisms, including inorganic transformations and vaporization, determining:

- The size distribution of the ash.

- The stickiness of the ash.

- The partitioning that occurs.

- To determine the physical transport mechanisms, focusing on:

- Elutriation from the bed.

- Attrition of sorbent, bed material, and ash.

- Fluidization characteristics.

- Thermophoresis, van der Waals attraction.

- Other applicable mechanisms to be identified. 
- To determine the mechanism and rate of deposition and sintering strength development on:

- In-bed tubes.

- Support surfaces.

- Convective pass tubes.

- Refractory surfaces.

- Other bed particles.

- To determine the mechanism and rate of agglomeration, focusing on:

- Material forming coating/bonding.

- Mineral species contributing to strength development.

- Conditions in the bed.

- To develop a predictive method for deposition and agglomeration.

- To identify measure(s) for mitigating ash-related problems.

\subsubsection{Scope of Work}

To meet the stated goals, the project was structured into six specific tasks. The tasks are listed below, with the goals and expected outcome of each presented.

- Task 1: Enhancement of Analytical Techniques

- Task 2: Analyses of Materials from Full-Scale FBCs

- Task 3: Bench-Scale Reactor Development and Testing

- Task 4: Applied Fundamental Chemistry and Physics

- Task 5: Development and Verification of Predictive Techniques and Mitigating Measures

- Task 6: Reporting

The overall goals of Task 1, Enhancement of Analytical Techniques, were to 1) provide the detailed data needed to elucidate ash behavior mechanisms in FBCs, 2) provide the sponsors with analysis techniques that would support predictive techniques and mitigating measures, and 3) develop a sampling and analysis protocol. The techniques developed provided detailed materials data needed to complete project goals, input into predictive techniques and mitigating measures, and sponsors with methods to better investigate ash behavior in FBCs.

For Task 2, Analyses of Material from Full-Scale FBCs, the goals were to 1) obtain data from operational systems for model development, 2) provide data to ensure validity and relevance of bench-scale tests, and 3) develop sampling guidelines. The information collected allowed detailed analyses of the fuel causing the problem, identified the coating and bonding material causing the agglomeration and deposition, indicated the mineral species contributing to strength development, provided data for developing a model to predict agglomeration and deposition, and ensured validity and relevance of bench-scale tests. 
The goals of Task 3, Bench-Scale Reactor Development, were to 1) simulate the process of agglomeration and deposition and 2) correlate chemical analysis with run operating variables to effectively predict the occurrence of agglomeration. The information collected provided a database of fuel, bed, and sorbent properties and operating conditions for model development. Task 3 resulted in a procedure or device to use to predict agglomeration and provided a device for studying mitigating measures.

For Task 4, Applied Fundamental Chemistry and Physics, the goals were to 1) determine the physical and chemical processes that result in the partitioning of ash components in FBCs and 2) better understand the physical and chemical interactions of ash components upon cooling, sintering, and deposition. The information collected during this task identified specific processes and conditions responsible for operational problems and provided input to the development of predictive techniques and mitigating measures for FBCs.

The goals of Task 5, Development and Verification of Predictive Techniques and Mitigating Measures, were to 1) use the data generated to develop a method of predicting agglomeration and deposition tendencies of any fuel, sorbent, and bed combination and 2) suggest methods of reducing or eliminating the problem. Some of the alternatives for expressing the predictive techniques are rules of thumb, a bench-scale test, advanced indices, a qualitative mechanistic model, and/or computer models.

The ultimate model would be an empirical algorithm to predict the rates of fines generation, sticky particle generation, elutriation, deposition on in-bed tubes and supports, agglomeration and defluidization, deposition on walls, and deposition on convective pass tubes. It is desirable to be able to predict these rates as a function of firing mode, velocity, bed type and size distribution, fuel type and size, sorbent, and oxygen concentration.

The goal of Task 6, Reporting, was to transfer results to sponsors in a timely fashion.

\subsection{Definition of Agglomeration}

Bed material agglomeration is defined as "the generation of particles significantly larger than the initial particles within the bed by deposition of inorganic products (from the fuel, calcined and sulfated sorbent, foreign material in the fuel and sorbent, and initial bed material) onto the surface of the bed particles and the subsequent sticking together of these particles to form larger clusters." In the agglomeration process, the solids do not typically melt, although some liquids may form on particle surfaces because of localized hot spots. Agglomeration in atmospheric fluidized-bed combustion (AFBC) systems generally occurs at temperatures between $1400^{\circ}$ and $1800^{\circ} \mathrm{F}$, which are below the melting point required to melt either the ash or bed material.

Agglomerates are usually observed to be brownish masses of aggregated enlarged grains of bed material and ash. Their structure can range from being very friable to strongly bonded by a glassy material or cementlike coating. Typically, individual bed material grains are embedded in a more or less continuous ashy matrix. Reaction textures are evident, with secondary phases appearing to grow along grain boundaries, in fractures, or in conjunction with layers of thick ash buildup. Limestone bed materials appear to recrystallize extensively to 
coarser-grained sulfate and other phases including iron-rich oxides, sulfur, and glass. Quartz grains may be coated with or partly embedded in glassy matrix materials, which frequently contain needlelike grains of silicate mineral. Mixed bed materials produce complex agglomerates with many or all the above-described features for both the quartz and limestone starting materials.

Agglomeration of the bed material manifests itself in various forms within the combustor and associated system components: 1) as growth of individual particles by adherence of very small fuel ash, sorbent, and attrition products to the larger initial bed grains; 2) as clusters of larger particles that adhere to each other to form raspberry-shaped agglomerates, which may be free-flowing in the bed; 3 ) as hollow "eggs" composed of sintered bed material; 4) as deposits onto surfaces within the combustion zone such as combustor walls, support structures, and heat exchange tubes; and 5) as in an extreme case, massive solidification in which most of the individual particles are bonded into large masses. This completely disrupts the normal operation of the combustor and may force an unscheduled shutdown.

The first indication of the occurrence of agglomeration is usually large differences in temperature at various locations in the bed, as well as fluctuations in measured temperatures with time. In addition, bed material drained from the combustor is usually coated with small nodules composed of small ash particles or fragments of bed material. This results in an increase in average particle size of the bed material which may cause difficulty in draining bed material from the combustor, erratic temperature measurements, and blockage or partial plugging of the recycle lines.

As the combustion process continues, a gradual but continuous decrease in overall heattransfer rate is observed. Other operating conditions, such as excess air, superficial gas velocity, and temperature, have to be altered to compensate. As agglomeration continues, the AFBC system performance deteriorates (fluidization decreases and $\mathrm{SO}_{2}$ and $\mathrm{CO}$ emissions increase). When massive solidification occurs the measured bed temperatures become very erratic and eventually become uncontrollable, and combustion must be terminated. In general, agglomeration affects all aspects of the AFBC combustion process.

\subsection{Definition of Low-Temperature Deposition}

Two main types of fouling problems have been identified in the convective passes of utility boilers. They are grouped as high-temperature, or conventional, fouling and lowtemperature fouling. The principal physical difference between the two types is the ash particle-to-particle bonding mechanism that strengthens the deposit. In high-temperature fouling, the bonding of particles is due to silicate liquid phases that flow and cement the deposit into a hard mass. Conventional high-temperature deposits most often form in the secondary superheater region of the convective pass. Low-temperature deposition has been known to occur often downstream of the secondary superheater, especially in boilers firing high-calcium subbituminous coals. While low-temperature deposits form at a relatively slow rate compared to high-temperature fouling, some types are resistant to sootblowing because they develop strength very rapidly. Moreover, low-temperature fouling occurs in convective pass zones which typically have less sootblower coverage than higher-temperature zones. Utility experience has shown that low-temperature fouling can cause long-term deterioration of 
convective pass heat-transfer surfaces, leading to an inability to reach reheat steam temperatures, boiler derates resulting from high exit gas temperature from the boiler convective pass, and also forced outages from convective pass plugging. It is especially significant in boilers designed for eastern U.S. coals that had switched to burning the lower-sulfur, highcalcium, western coals. For fluid-bed applications, all deposition occurs in the low-temperature regions.

The physical nature of ash-fouling deposits varies dramatically through the convective pass. Four or five distinct deposit morphologies were commonly found in boilers burning highcalcium western U.S. coals. They include conventional, or high-temperature, fouling deposits and four types of low-temperature deposits known as upstream massive, upstream enamel, double-crested upstream, and downstream powder deposits. The conventional fouling deposits formed on the upstream (windward) side of steam tubes in secondary superheater regions are massive and appear much like sandstone, although in certain cases, they have completely fused into molten masses. By the definition given here, they do not contain sulfur, form at temperatures above approximately $1900^{\circ} \mathrm{F}$, and are not typically seen in FBCs.

In the $\mathrm{FBC}$, temperatures are below $1900^{\circ} \mathrm{F}$, allowing $\mathrm{SO}_{2}$ in the gas to react with calcium and other elements in the deposits to form sulfates which are indicative of lowtemperature deposits. The massive deposits that form on the upstream side of the reheater tubes in conventional pulverized coal (pc)-fired systems are less lustrous than conventional fouling deposits, often dull reddish or brownish in color. They can be very massive and hard, almost always occurring as a fin whose base covers the tube, and can extend a foot or more into the gas stream, forming a sharp ridge. Sootblowers need to be more closely spaced vertically in this region to prevent the accumulation of these massive upstream deposits. Such deposits do not normally grow dramatically in width to close off the flow through the region unless the boiler design permits a region of gas turbulence that will make the direction of growth transverse to the rest of the gas stream, or unless a piece of a deposit breaks off and lodges between plenums. If this occurs, the broken piece acts as a seed that initiates rapid growth of blocking deposits. Most FBCs operate at lower temperatures and do not see this type of deposition.

Farther back in the pass of pc-fired systems, gases cool to the point that the ash particles are no longer sticky and massive deposits on the upstream sides of tubes no longer form; these conditions are more typical of the FBC. Instead, a thin, hard, enamel-like coating forms on the upstream sides of the tubes. When formed at higher temperatures, this layer is essentially hard upon deposition; i.e., strength does not need time to develop. At lower temperatures, strength is not immediate, but does develop quickly. Therefore, sootblowing of these deposits is less effective than with most other types of deposits. Effectiveness could possibly be improved if thermal shocking is significant, such as when water is used as the blowing medium. Off-line removal of the deposits is equally difficult. Because these deposits are well-sintered in a short time, and because they tend to be thin and build slowly, they do not dramatically impede heat transfer. However, the layer can act as a capture surface which absorbs the energy of incoming ash particles so that they stick to the steam tubes at lower temperatures than if the layer were not present. In this way, they can initiate the formation of a massive deposit. This is believed to be the method of initiation of the upstream massive low-temperature deposits. In addition, because the enamel layers are rich in sulfur, they can corrode the tubes at higher temperatures, 
although at the lower skin temperatures of the primary superheater and economizer tubes, corrosion is usually not a problem.

The third type of low-temperature deposition occurs on the downstream sides of steam tubes all through the convective pass. Such deposits occur all through the convective pass of a boiler, but usually become much thicker in the horizontal steam- and water-tube banks of the primary superheater and economizer. These deposits do not bond to the tube surface.

Sintering of this type of deposit collected on probes is only evident on the outer edges as they become thicker, although light sintering is evident in deposits formed in utility boilers over periods of months. Instead, the deposits are usually powdery or very friable and often shed from vertical tube banks. However, they can completely fill the interstitial spaces between steam tubes in a plenum, especially in horizontal banks. If sootblower coverage is not available and if there is some turbulence so that the deposits grow between plenums, they can grow to block flow. Also, because these deposits are poorly sintered and can cover over one half of the tube surface in a bank, they significantly reduce heat transfer in banks where they are prevalent. Because the lead tubes in a bank protect them from the sootblower blast, they can form in the immediate vicinity of sootblowers, although in such cases they will not grow between plenums. 


\section{0 \\ DEVELOPMENT OF \\ SAMPLING AND ANALYTICAL TECHNIQUES}




\section{TABLE OF CONTENTS}

2.0 DEVELOPMENT OF SAMPLING AND ANALYTICAL TECHNIQUES $\ldots \ldots \ldots 2-1$

2.1 Sampling and Analysis Protocol $\ldots \ldots \ldots \ldots \ldots \ldots \ldots \ldots \ldots .2-1$

2.2 Development of Methods for Investigating Bed Particle Coating and

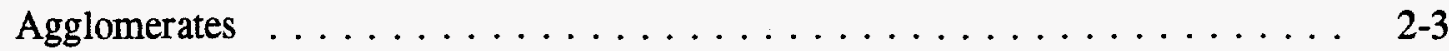

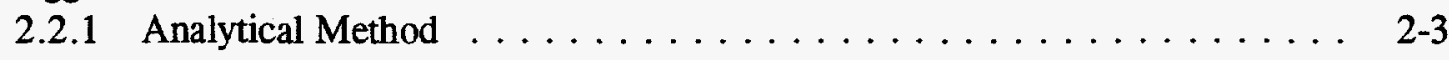

2.2.2 Methods Demonstration .................. $2-4$

\section{LIST OF FIGURES}

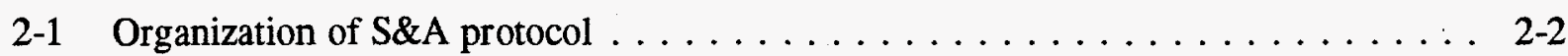

2-2 Backscattered electron image of agglomerates $\ldots \ldots \ldots \ldots \ldots \ldots \ldots \ldots$

2-3 Backscattered electron image of an agglomerate $\ldots \ldots \ldots \ldots \ldots \ldots \ldots$

2-4 Deposition of ash on bed particles $\ldots \ldots \ldots \ldots \ldots \ldots \ldots \ldots \ldots \ldots . \ldots \ldots$

2-5 Size distribution of the sandstone bed materials $\ldots \ldots \ldots \ldots \ldots \ldots \ldots . \ldots \ldots$

2-6 Amount of ash deposited as coating on bed particles $\ldots \ldots \ldots \ldots \ldots \ldots$ 2-7

2-7 Major elemental chemical composition of ash coatings $\ldots \ldots \ldots \ldots \ldots \ldots$ 2-8

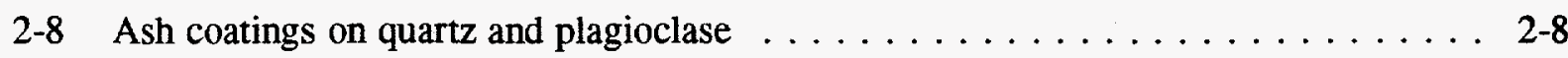

\section{LIST OF TABLES}

2-1 Sodium Contents of the Test Coals $\ldots \ldots \ldots \ldots \ldots \ldots \ldots \ldots \ldots \ldots \ldots \ldots$

2-2 Quantitative Mineralogy of the Sandstone Beds $\ldots \ldots \ldots \ldots \ldots \ldots \ldots$ 2-6

2-3 Average Enrichment and Depletion Factors for Agglomerate Neck Growths . . . . . 2-9 


\subsection{DEVELOPMENT OF SAMPLING AND ANALYTICAL TECHNIQUES}

Several techniques were developed to provide the detailed data needed to complete the project goals. One of the first items developed was a sampling protocol to ensure complete and consistent sampling for this program and to provide users with a guide for future sampling efforts. Analytical techniques, especially those making use of the scanning electron microscope (SEM), were enhanced as a part of this program. This was necessary because of the unique properties of the FBC-generated ash and coated bed materials. The development of these techniques will be reviewed in this section.

\subsection{Sampling and Analysis Protocol}

In order to diagnose and reduce ash-related problems in FBC systems, a detailed understanding of the fuel, ash, and system materials properties must be achieved. This understanding requires that the materials be analyzed in detail to assess their chemical and physical characteristics. Effective materials analysis requires appropriate and effective materials-sampling techniques. Because the materials sampling often must be performed by operations personnel, it is important that a standard method of sampling is available. The sampling and analysis protocol developed as part this project is intended to aid the operations engineer in providing relevant samples for analysis and testing. An appreciation of the appropriate analysis and testing, addressing various issues for different sample types, is necessary for correct sampling. The operations engineers must be aware of the analysis and testing services available to them to select the best analyses to solve various operational issues. A further benefit of consistently applied protocols is the establishment of materials data that are comparable from one run to the next and can be related to operational information. The development of sampling and analysis protocols would result in consistent data that can be used to reduce ash-related problems.

This protocol (outlined in Figure 2-1) is organized to provide a handy reference for those involved with FBC operations. The background section is not intended as a comprehensive overview of operational effects of ash in FBC systems, but rather as a quick, practical guide to the basics of ash behavior, sampling, and analysis. The section on sampling and analysis protocols specifically addresses strategies intended to reduce ash-related operational problems. These sections are designed to provide the information needed for operations personnel to effectively address ash-related operational issues and to efficiently interpret the direct analysis performed. The Appendix provides detailed overviews of the sampling and analytical strategies recommended by the authors of this report. While an outline of the sampling and analysis protocol is shown in Figure 2-1, the actual protocol was issued as a separate topical report during the second year of the project. 


\section{Outline of}

FBC Sampling and Analysis: Protocols to Aid in the Prediction and Control of Ash-Related Operational Problems

1.0 INTRODUCTION

1.1 Program Overview

1.2 The Need for Sampling and Analysis Protocols

2.0 BACKGROUND

2.1 Agglomeration in FBCs

2.2 Deposition in FBCs

3.0 SAMPLING AND ANALYSIS PROTOCOLS INTENDED TO REDUCE ASHRELATED OPERATIONAL PROBLEMS IN FBC SYSTEMS

3.1 Sampling Protocols

3.1.1 Operational Data

3.1.2 Fuel Sampling Procedures

3.1.3 Bed Material Sampling Procedures

3.1.4 Agglomerate Sampling Procedures

3.1.5 Fly Ash Sampling Procedures

3.1.6 Ash Deposit Sampling Procedures

3.2 Analytical Protocols

3.2.1 Analysis Strategy

3.2.2 Fuel Analysis Procedures

3.2.3 Bed Analysis Procedures

3.2.4 Agglomerate Analysis Procedures

3.2.5 Fly Ash Analysis Procedures

3.2.6 Deposit Analysis Procedures

\subsection{CASE STUDIES}

4.1 Incidents in Full-Scale Systems under Normal Operating Conditions

4.2 Agglomeration in Full-Scale Utility Boilers Because of Operational Upsets

5.0 CONCLUSIONS

6.0 LITERATURE CITED

7.0 APPENDIX

Standard and Advanced Analytical Procedures

8.0 ATTACHMENT

Standard Sampling Procedures and Data Sheets

Figure 2-1. Organization of S\&A protocol. 


\subsection{Development of Methods for. Investigating Bed Particle Coating and Agglomerates}

Several analytical methods have been developed and applied to characterize the physical and chemical properties of bed particles that may be important in controlling ash deposition and agglomeration. These properties include the particle-size distribution and quantitative mineralogy of unaltered bed particle cores and the chemical composition and proportion of their corresponding ash coatings. The methods employ an automated SEM integrated with a digital image analysis system and an energy-dispersive $x$-ray spectrometer. This instrumentation is useful for characterizing complex heterogeneous bed materials because it provides the capability to analyze individual particles efficiently for both compositional and morphological information. Detailed descriptions of the analytical methods, along with an example of how they can be applied to FBC-generated samples, were provided in the Sampling and Analysis Protocol.

\subsubsection{Analytical Method}

Bed materials are mounted in epoxy resin, cross-sectioned, and polished using standard petrographic procedures. The sample is then sputter-coated with carbon to minimize electron beam charging artifacts. A Noran Instruments automated digital electron microscope integrated with an image analyzer and an energy-dispersive $\mathrm{x}$-ray spectrometer is used for analyzing bed materials.

A digital backscattered electron (BSE) image of a random area on the sample surface is acquired at a spatial resolution of 512 pixels in both the line scan (x-axis) and frame scan (y-axis) directions. Frame averaging is employed to enhance image quality. Bed particles, with their corresponding ash coatings, are easily delineated based on the atomic number contrast inherent in BSE imaging. The seemingly unaltered mineral cores of bed particles and their corresponding alteration rims (i.e., ash coatings) are segmented from the gray-scale BSE image into separate binary images using the standard histogram analysis method and Boolean logic. The binary transformation process requires operator intervention to create binary images of the entire bed particle and the unaltered bed particle core that accurately represent the original image. The exclusive or (EOR) Boolean operation is then performed on the two binary images to create a binary image of the ash coating. After transforming the gray-scale image into bed particle core and coating binaries, the mean particle projection and area are determined for each binary of a given particle using standard image analysis techniques. Two correlation parameters are also determined: an indication of whether the bed mineral grain is included or attached relative to the ash coating and the amount of mineral perimeter in contact with the ash coating or mounting medium. In addition to these morphological and phase correlation data, compositional information is obtained by rastering the beam over the core and coating of bed particles to acquire an energy-dispersive $x$-ray spectrum. Spectral regions of interest (ROI) are defined to measure the characteristic $x$-ray emission intensities of twelve common, mineralforming, major and minor elements ( $\mathrm{Na}, \mathrm{Mg}, \mathrm{Al}, \mathrm{Si}, \mathrm{P}, \mathrm{S}, \mathrm{Cl}, \mathrm{K}, \mathrm{Ca}, \mathrm{Ti}, \mathrm{Fe}$, and $\mathrm{Ba}$ ). Relative intensities are calculated by dividing the net counts for each element by the total ROI counts for all elements. The acquired data are transferred to a personal computer and stored to disk for subsequent reduction and report generation. The data are reduced and analyzed using a spreadsheet program. 
A digital BSE image of an area on the sample containing one or more agglomerates is acquired. The neck growth and ash coating components of agglomerates are easily delineated based on the atomic number contrast inherent in BSE imaging (Figure 2-2). The electron-beam automation system is programmed to perform quantitative energy-dispersive $\mathrm{x}$-ray microanalysis at locations specified by the operator. In this study, six analyses were performed per bed particle as indicated in Figure 2-3. The x-ray intensity data are corrected for matrix effects, and concentrations are calculated using the ZAF (atomic number, absorption, and fluorescence) correction procedure. Mineral standards were used to calibrate the procedure. Thirteen elements $(\mathrm{O}, \mathrm{Na}, \mathrm{Mg}, \mathrm{Al}, \mathrm{Si}, \mathrm{P}, \mathrm{S}, \mathrm{Cl}, \mathrm{K}, \mathrm{Ca}, \mathrm{Ti}, \mathrm{Fe}$, and $\mathrm{Ba})$ were included in the analysis. The analyses are transferred on-line to a personal computer for reduction and archival purposes. The acquired digital images with documented analysis locations can also be archived. The analysis results are manipulated using a spreadsheet program.

\subsubsection{Methods Demonstration}

Bed materials produced in a bench-scale bubbling FBC were analyzed to demonstrate the utility of these methods. Three samples of Beulah North Dakota lignite were used as fuel with sandstone as the bed. All tests were conducted at a bed temperature of $1550^{\circ} \mathrm{F}$, velocity of 6 $\mathrm{ft} / \mathrm{sec}$, and $20 \%$ excess air. The most variable test parameter was the sodium content of the coal samples, as indicated in Table $2-1$.

The initial stage of agglomeration involves the deposition of ash on bed particle surfaces, as exemplified in Figure 2-4. Most of the bed particles in all three test samples were coated with ash. The analytical method described in the Sampling and Analysis Protocol was used to size and chemically analyze the seemingly unaltered sand grains composing the cores of most bed particles.

As expected, the size distribution (Figure 2-5) and quantitative mineralogy (Table 2-2) of the three sandstone bed materials were similar.

The ash coating component of bed particles was also analyzed using the method described in the Sampling and Analysis Protocol. The amount of ash coating (Figure 2-6) correlates well with the sodium contents of the coal fuels (Table 2-1). This relationship has been noted in previous studies. Figure 2-6 also indicates that ash coated the sandstone quartz and plagioclase grains in a given sample to a similar extent. Apparently, bed mineralogy was not a factor in controlling ash deposition.

The coatings are enriched in $\mathrm{Na}, \mathrm{Mg}, \mathrm{Ca}, \mathrm{Fe}$, and $\mathrm{S}$ (Figure 2-7). The chemical composition of ash deposited on quartz and plagioclase bed particles in a given sample is essentially identical (Figure 2-8). This indicates a lack of chemical reaction between the sandstone grains and coatings. In addition, the very distinct interface between sandstone grains and coatings is consistent with a lack of chemical reaction (Figure 2-4). The evidence presented in Figures 2-4, 2-6, 2-7, and 2-8 clearly indicates that the deposition of ash coating during the FBC test runs was not influenced by the chemical or mineralogical composition of the original sandstone bed. 


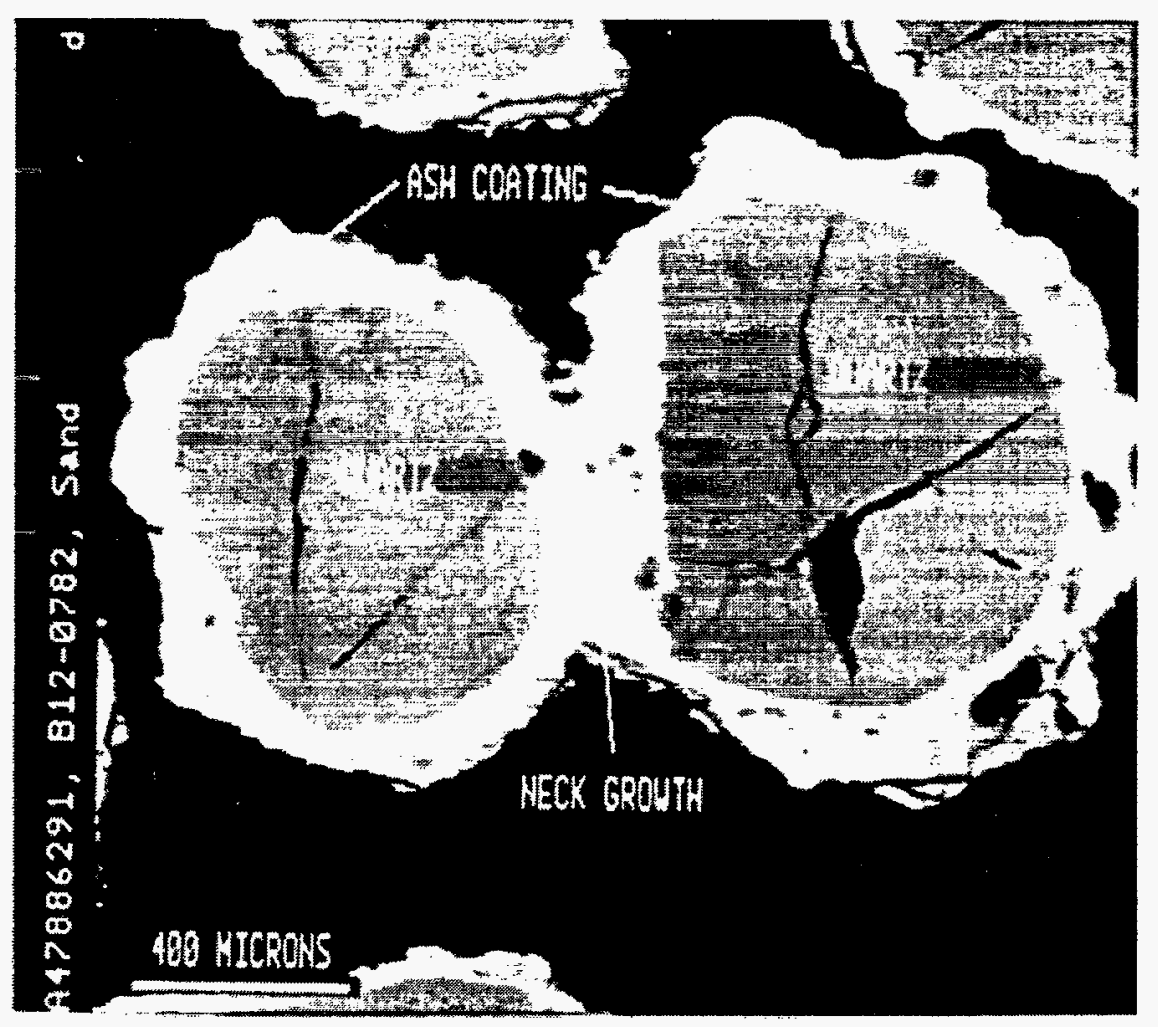

Figure 2-2. Backscattered electron image of agglomerates.

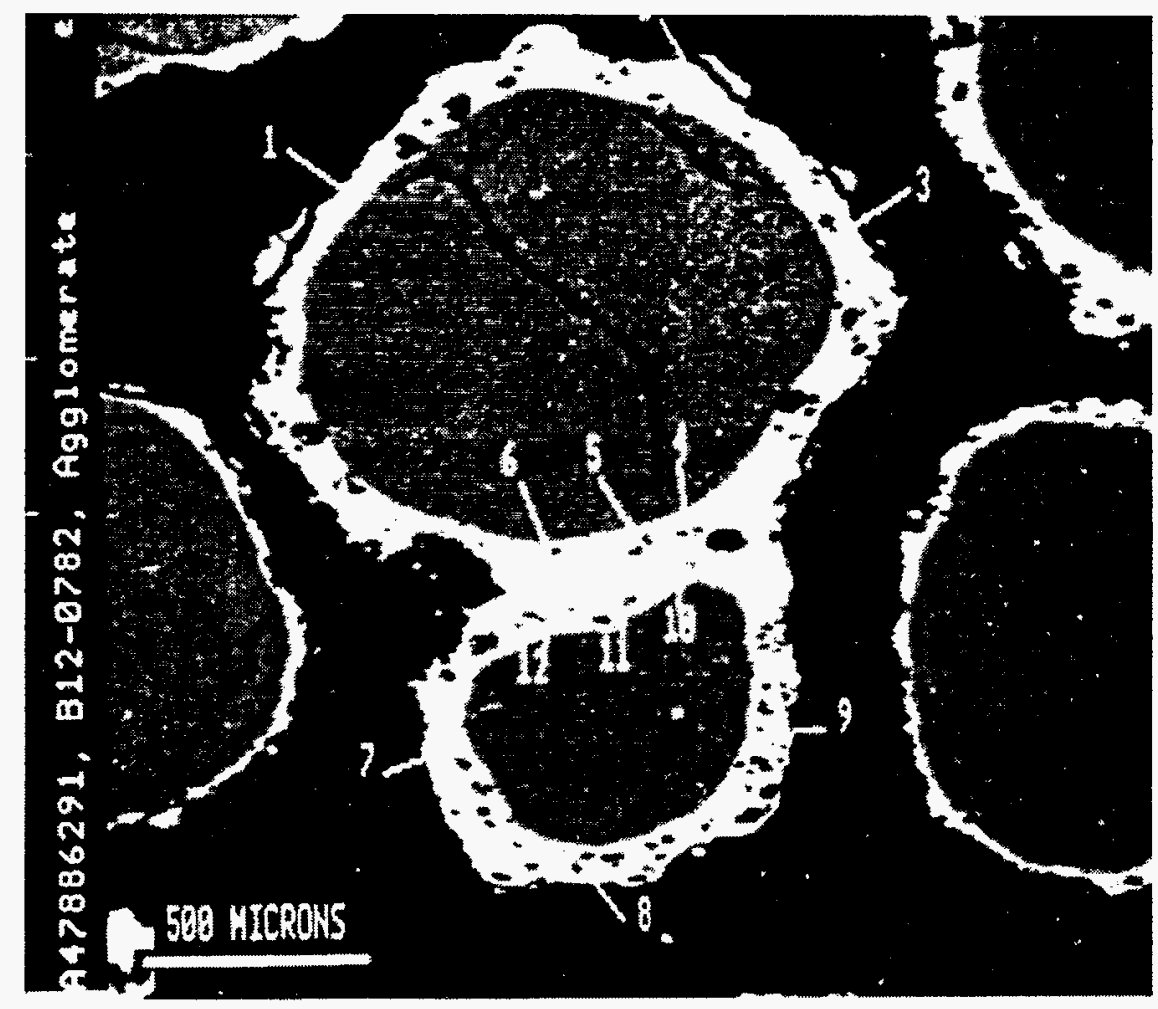

Figure 2-3. Backscattered electron image of an agglomerate. The locations where electron probe microanalysis was performed are indicated. 


\section{TABLE 2-1}

Sodium Contents of the Test Coals

\begin{tabular}{lc}
\hline Sample & $\mathrm{Na}_{2} \mathrm{O}, \mathrm{wt} \%$, ash basis \\
\hline BW7-0382 & 4.1 \\
B12-0782 & 9.6 \\
BI4-0982 & 9.5 \\
\hline
\end{tabular}

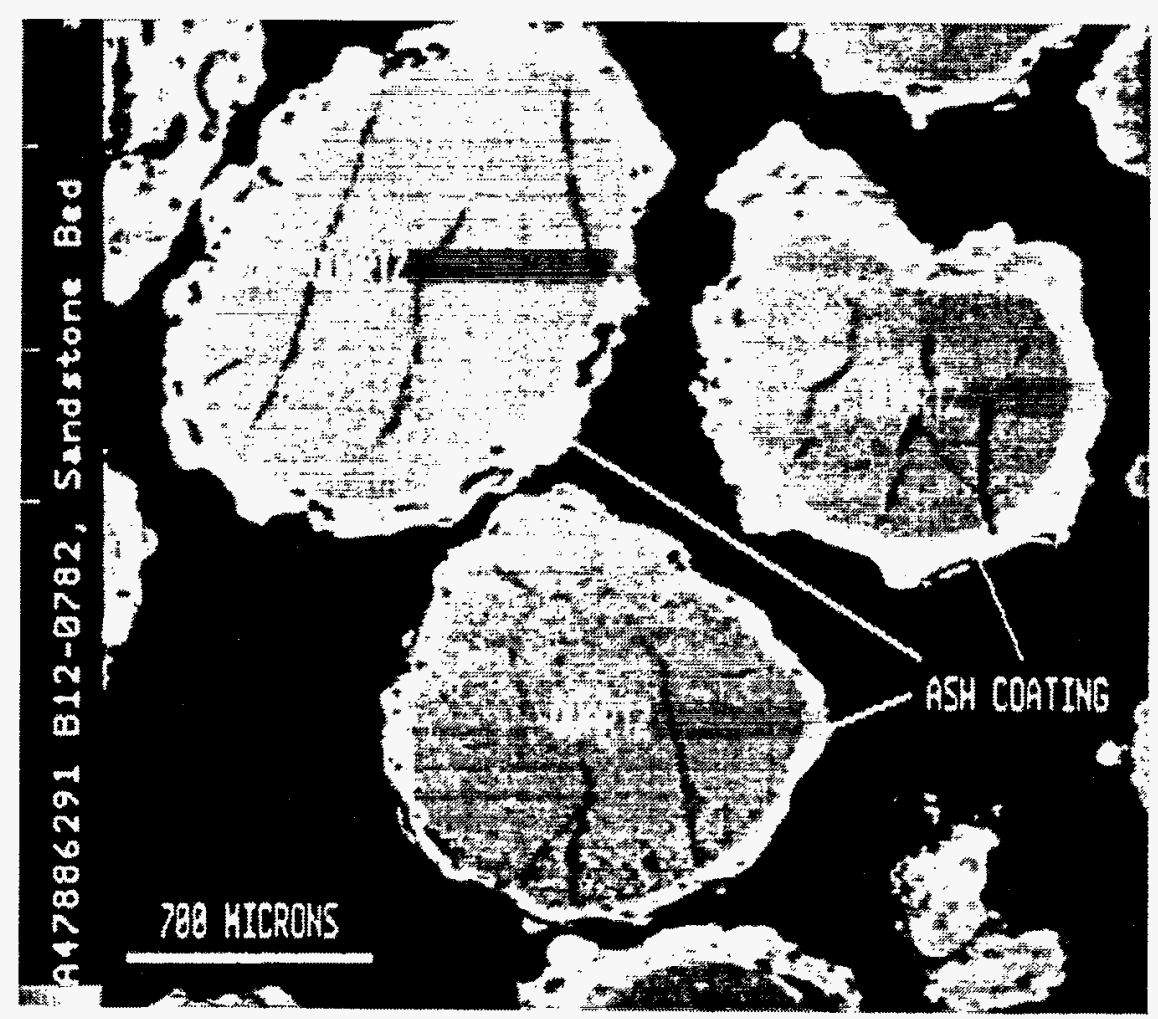

Figure 2-4. Deposition of ash on bed particles. 


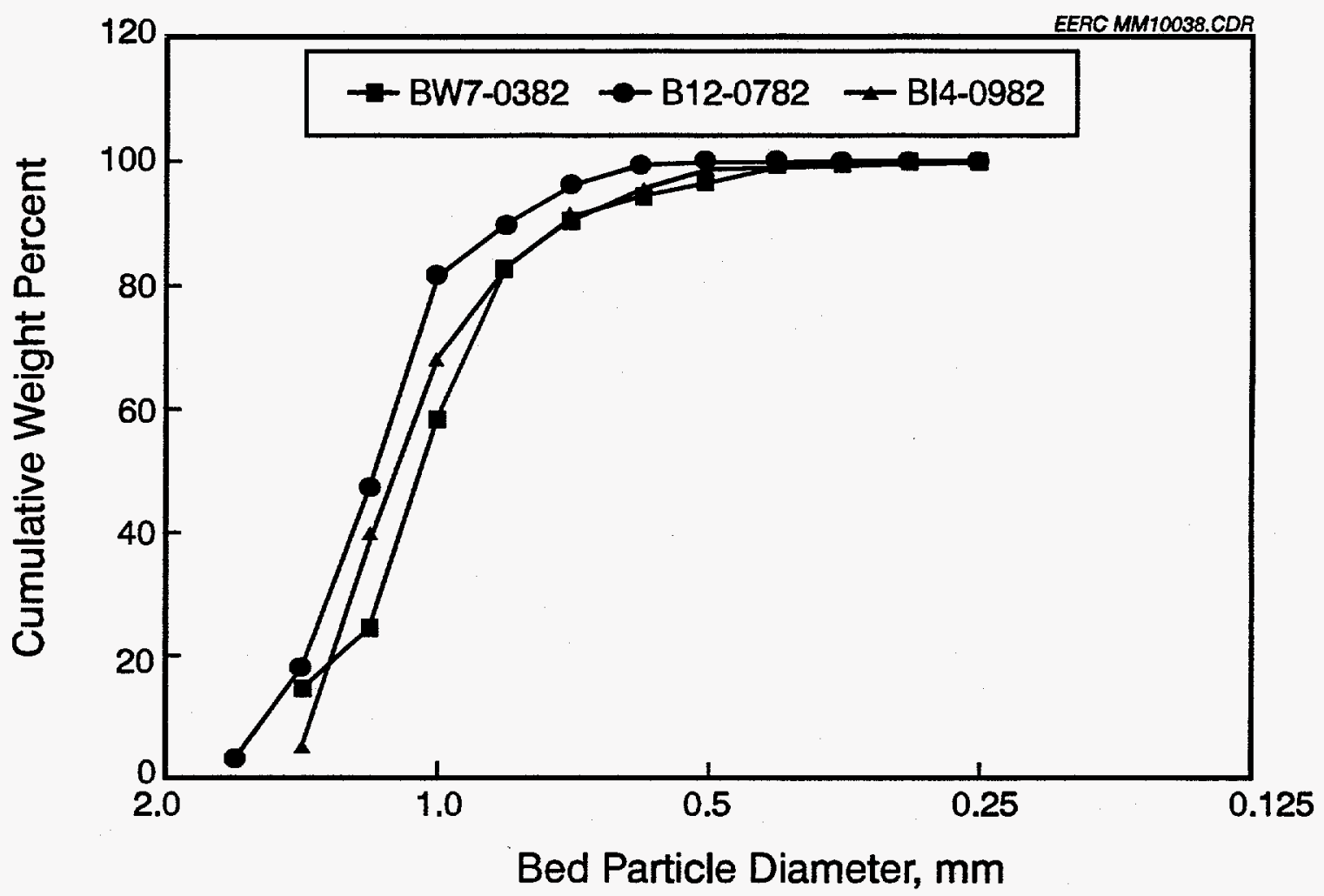

Figure 2-5. Size distribution of the sandstone bed materials.

TABLE 2-2

Quantitative Mineralogy of the Sandstone Beds

\begin{tabular}{lccc}
\hline Sample & BW7-0382 & BI2-0782 & BI4-0982 \\
\hline Quartz, wt\% & 94.7 & 94.0 & 95.0 \\
Plagioclase, wt\% & 5.3 & 6.0 & 4.8 \\
Clay, wt\% & $\mathrm{ND}^{1}$ & $\mathrm{ND}$ & 0.2 \\
$\mathrm{~N}^{2}, \mathrm{wt} \%$ & 64 & 98 & 105 \\
\hline
\end{tabular}

${ }^{1}$ Not detected.

${ }^{2}$ Number of particle cores analyzed. 


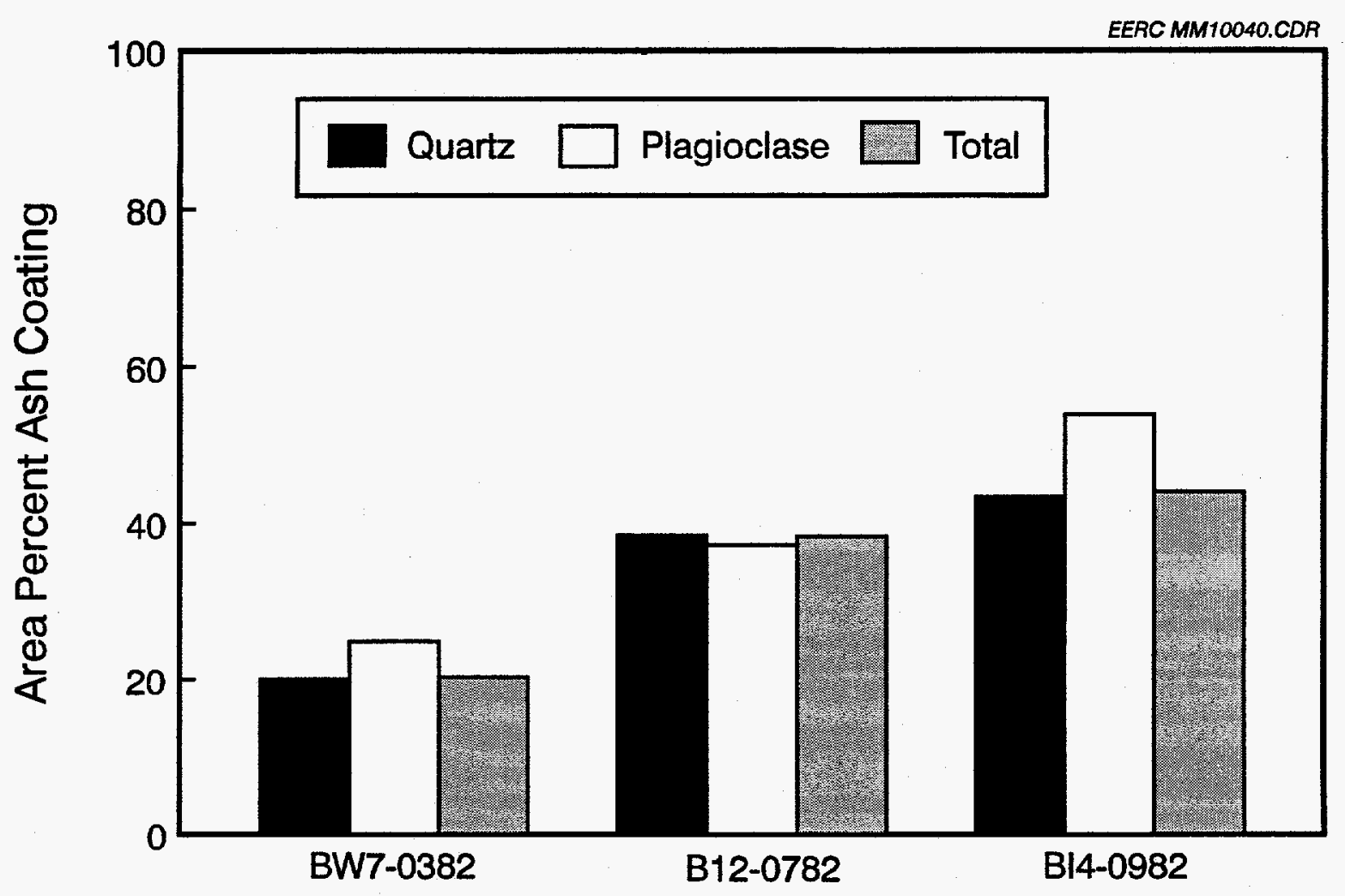

Figure 2-6. Amount of ash deposited as coating on bed particles.

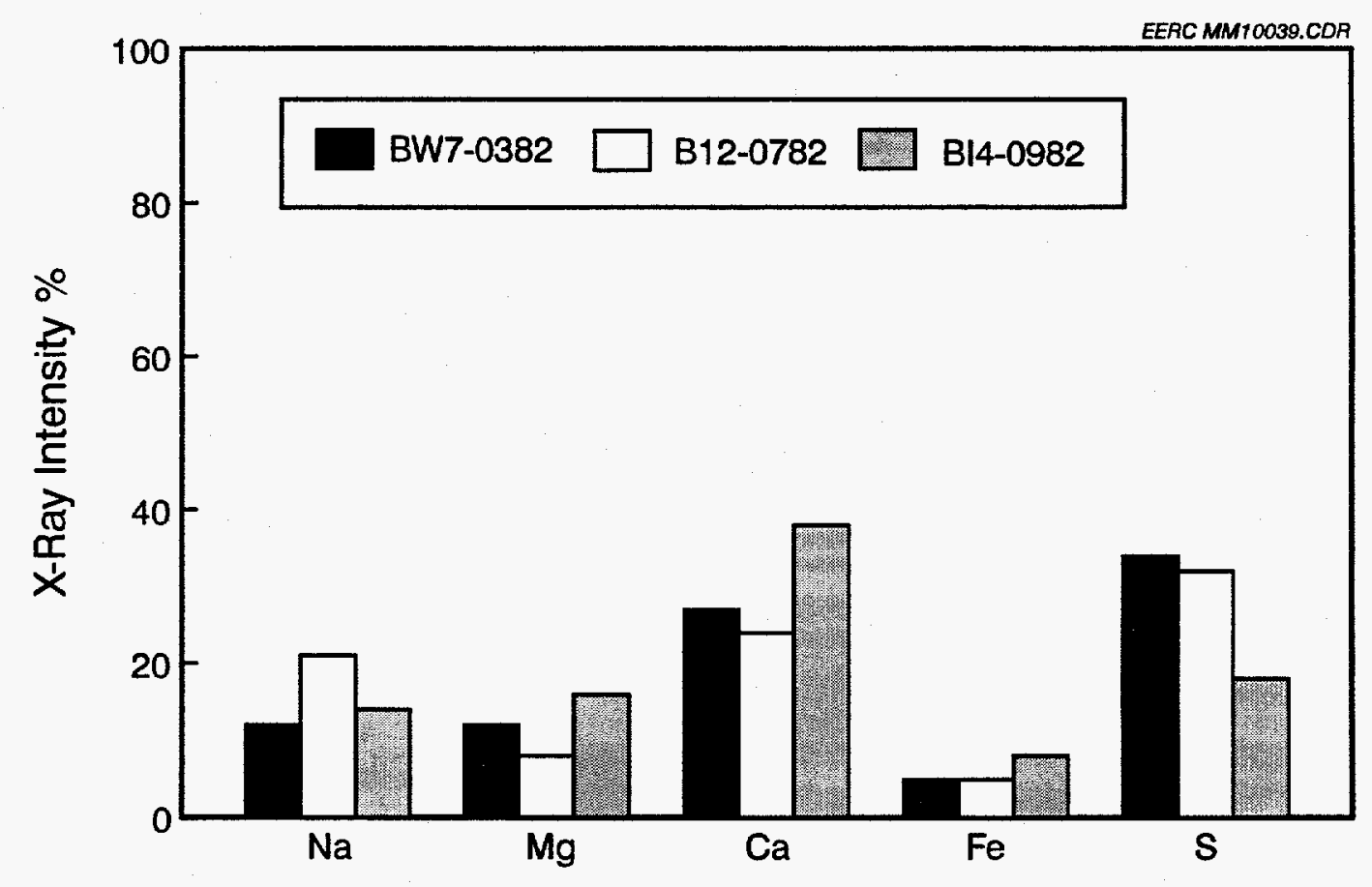

Figure 2-7. Major elemental chemical composition of ash coatings. 


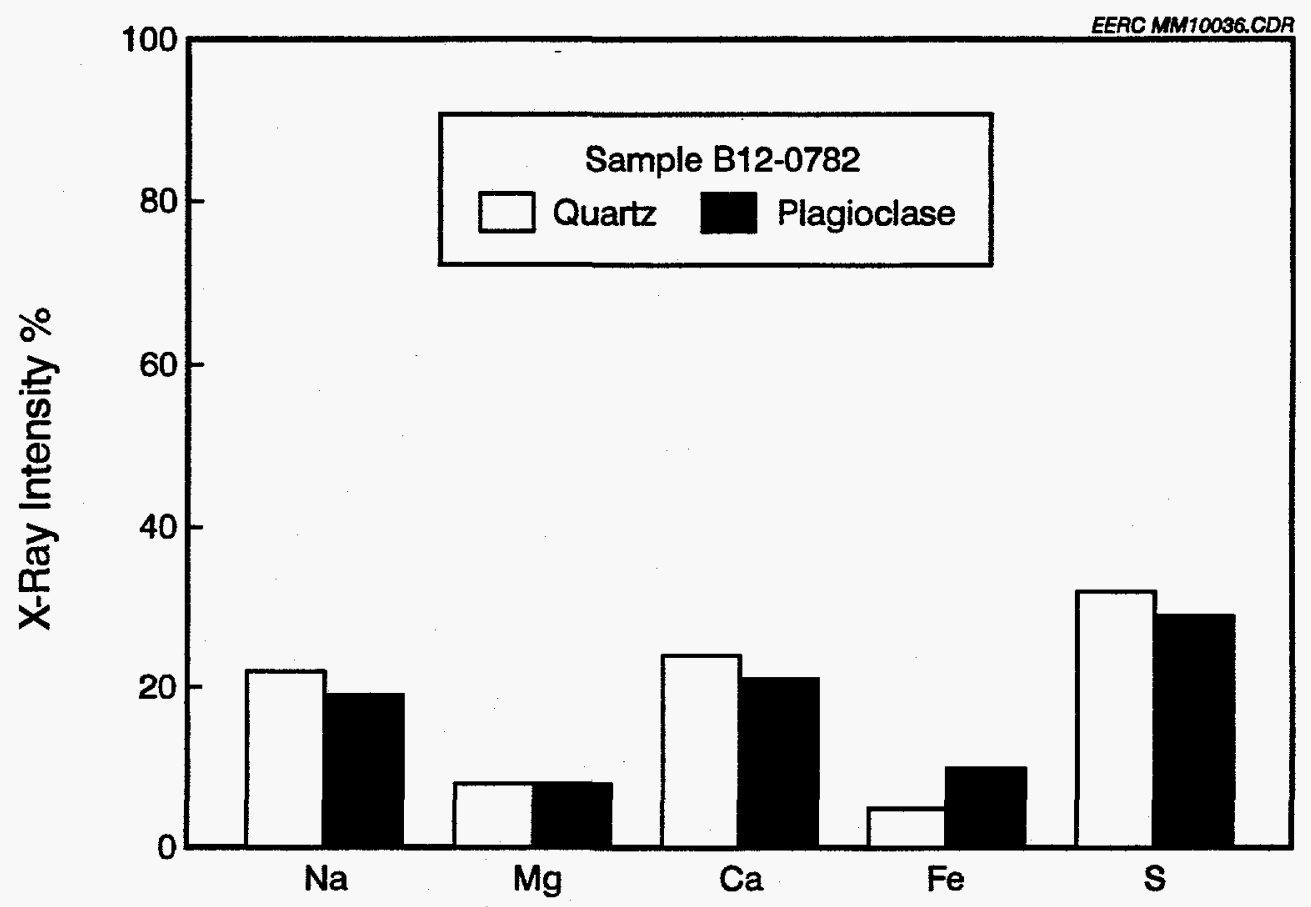

Figure 2-8. Ash coatings on quartz and plagioclase.

During the intermediate stage of agglomeration, two or more ash-coated bed particles cohere via sulfate sintering to form a particle composite. The portion of ash coating in mutual contact with two of the original bed particles is referred to as a neck growth (Figure 2-2). A SEM analysis procedure was devised to investigate whether neck growth development is promoted by differences in the major element composition of the interface between agglomerating particles and the ash coating around the participating bed particles.

Numerous agglomerates were formed in Test B12-0782. The agglomeration may be attributable to the sodium enrichment of the ash coating relative to the other samples (Figure 27). A total of 303 chemical analyses were performed, following the procedure described in the Sampling and Analysis Protocol, on 52 neck growths and their corresponding ash coatings. Multiple analyses were performed and then averaged to adequately characterize each neck growth-ash coating pair. Enrichment and depletion factors (ratios of elemental concentrations in the neck growth region to concentrations in the corresponding ash coatings) are presented in Table 2-3. The large standard deviation in enrichment and depletion factors is indicative of the chemical heterogeneity of the neck growths and ash coatings. The factors are not significantly greater than or less than one, indicating that the neck growth region is not compositionally different from the original ash coating. These results indicate that neck growth development and, hence, agglomeration occur as a result of random collision between ash-coated bed particles. More details will be given in later sections on the occurrence and mechanism for agglomeration. 


\section{TABLE 2-3}

Average Enrichment and Depletion Factors for Agglomerate Neck Growths

\begin{tabular}{lcc}
\hline Element & Enrichment/Depletion Factor & Standard Deviation \\
\hline $\mathrm{Na}$ & 1.05 & 0.65 \\
$\mathrm{Mg}$ & 1.32 & 1.14 \\
$\mathrm{~S}$ & 0.99 & 0.37 \\
$\mathrm{~K}$ & 1.25 & 0.98 \\
$\mathrm{Ca}$ & 1.22 & 0.54 \\
$\mathrm{Fe}$ & 1.50 & 2.36 \\
\hline
\end{tabular}


3.0

FULL-SCALE SAMPLING 


\section{TABLE OF CONTENTS}

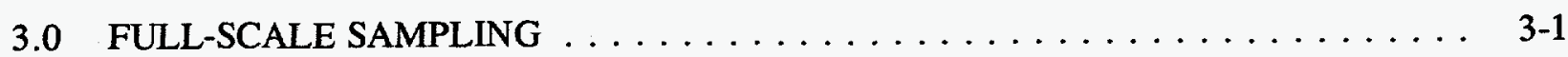

3.1 Full-Scale Sampling Objectives $\ldots \ldots \ldots \ldots \ldots \ldots \ldots \ldots \ldots \ldots \ldots \ldots$. . . . . . . . . .

3.2 Review of Sampling Activities . . . . . . . . . . . . . . . . . $3-1$

3.2.1 Montana-Dakota Utilities . . . . . . . . . . . . . . . . 3-1

3.2.2 Northern States Power Company . . . . . . . . . . . . . . . . 3-4

3.3 Results of Bulk Chemistry Analyses ..... . . . . . . . . . . . 3-4

3.3 .1 Montana-Dakota Utilities . . . . . . . . . . . . . . . . 3-4

3.3.2 Northern States Power Company ... . . . . . . . . . . . . 3-13

3.4 Morphological Examination . . . . . . . . . . . . . . . . 3-14

3.4.1 Montana-Dakota Utilities . . . . . . . . . . . . . . . . 3-14

3.4.2 Northern States Power Company . . . . . . . . . . . . . . 3-16 


\section{LIST OF FIGURES}

3-1 Location of end-of-test deposit samples collected by EERC personnel on

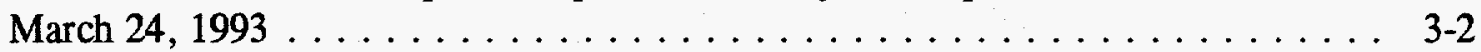

3-2 Location of run-time samples collected by MDU personnel on March 3, $1993 \ldots$. . . . 3-2

3-3 Comparison of deposits collected from the Heskett Station $\ldots \ldots \ldots \ldots \ldots$. . . . .

3-4 Comparison of run-time samples collected from the Heskett Station . . . . . . . 3-8

3-5 Comparison of deposit and coal ash chemistry for various locations in the Heskett Station . . . . . . . . . . . . . . . . . . . 3-9

3-6 Comparison of deposit and fly ash chemistry from the Heskett Station . . . . . . . . 3-9

3-7 Comparison of run-time samples with sampling location for the Heskett Station . . . 3-11

3-8 Comparison of bed material and bed deposit chemistry from the Heskett Station . . 3-11

3-9 Comparison of bed material and bed deposit chemistry from the Black Dog Station . 3-14

3-10 Line scan analysis of a coated bed material from the Heskett Station . . . . . . . 3-15

3-11 Sodium line scan for a Black Dog bed material particle $\ldots \ldots \ldots \ldots \ldots$. . . . . .

\section{LIST OF TABLES}

3-1 End-of-Test Deposit Samples Collected by EERC Personnel on March 24, 1993 . . . 3-3

3-2 Run-Time Samples Collected by MDU Personnel on March 3, $1993 \ldots$. . . . . . . . 3-3

3-3 Proximate and Ultimate Analysis of Beulah Lignite Coal Used at the Heskett Station . 3-5

3-4 X-Ray Fluorescence Analysis of the Ash from the Beulah Lignite Coal Used at the

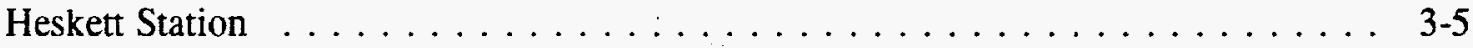

3-5 Summary of CCSEM Results for Heskett Station Beulah Lignite Coal . . . . . . . . 3 3-6

3-6 Chemical Fractionation Results of the Beulah Lignite Coal Used at the Heskett Station 3-6

3-7 XRF/Elemental Analysis of Heskett Station Samples . . . . . . . . . . . . . 3-7

3-8 Samples Collected by NSP Personnel $\ldots \ldots \ldots \ldots \ldots \ldots \ldots \ldots \ldots \ldots$

3-9 Oxide Analysis of Selected Points from Clay-Colored Agglomerate . . . . . . . 3-18 


\subsection{FULL-SCALE SAMPLING}

\subsection{Full-Scale Sampling Objectives}

One of the primary accomplishments of the project was sampling and analyzing deposits and agglomerates from a full-scale, fluidized-bed combustor and interpreting the results. The specific goals of the full-scale sampling included the following:

- To identify chemical and physical characteristics of ash that influence agglomeration and deposition

- To obtain data from operational systems to begin mechanistic model development

- To develop sampling and analytical protocols that a company could use to guide sample collection

- To provide data to ensure the validity and relevance of bench-scale tests

The information that was sought from this effort was a detailed analysis of the fuel causing the problem, an identification of the coating and bonding material causing the deposition and agglomeration, and an indication of mineral species contributing to strength development. It was also envisioned that this effort would provide data for developing a model to predict agglomeration and deposition. The data collected would also be used to ensure the validity and relevance of bench-scale tests.

\subsection{Review of Sampling Activities}

\subsubsection{Montana-Dakota Utilities}

Samples were collected from the MDU R.M. Heskett Station. Unit Number 2 at the Heskett Station is an 80-MWe bubbling FBC. This unit, originally stoker-fired, was retrofitted by Babcock \& Wilcox (B\&W) to its current configuration. The furnace is $40 \mathrm{ft}$ wide by $25 \mathrm{ft}$ deep. The unit typically operates at a bed temperature of $1500^{\circ} \mathrm{F}$ and a bed depth of 51 in.

The sampling trip occurred on March 24, 1993, after a routine shutdown of the unit. Run-time samples (e.g., coal and ash) were collected by MDU during the last week of operation prior to the shutdown. Deposits and agglomerates were collected by EERC personnel with assistance from MDU personnel. Figures 3-1 and 3-2 show sampling locations listed in Tables 3-1 and 3-2. It should be noted that a dual numbering system is used. During the sampling activities, each sample collected was given a number in the chronological order that it was collected. During data interpretation, the samples were given a location number or letter that refers to a specific location in the boiler. The number system used starts with Location 1 at the bottom of the boiler and increases toward the back of the boiler. 


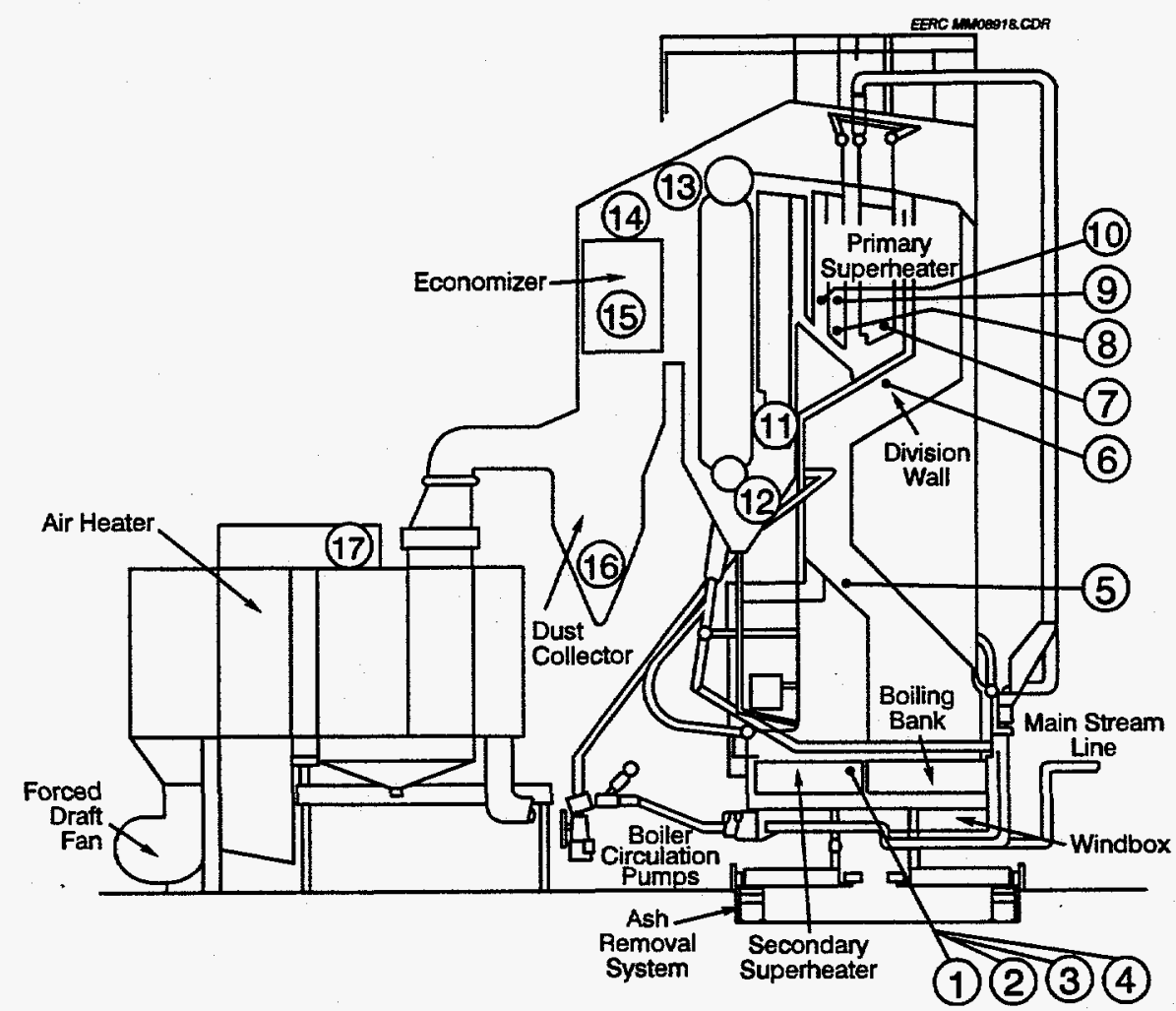

Figure 3-1. Location of end-of-test deposit samples collected by EERC personnel on March 24, 1993.

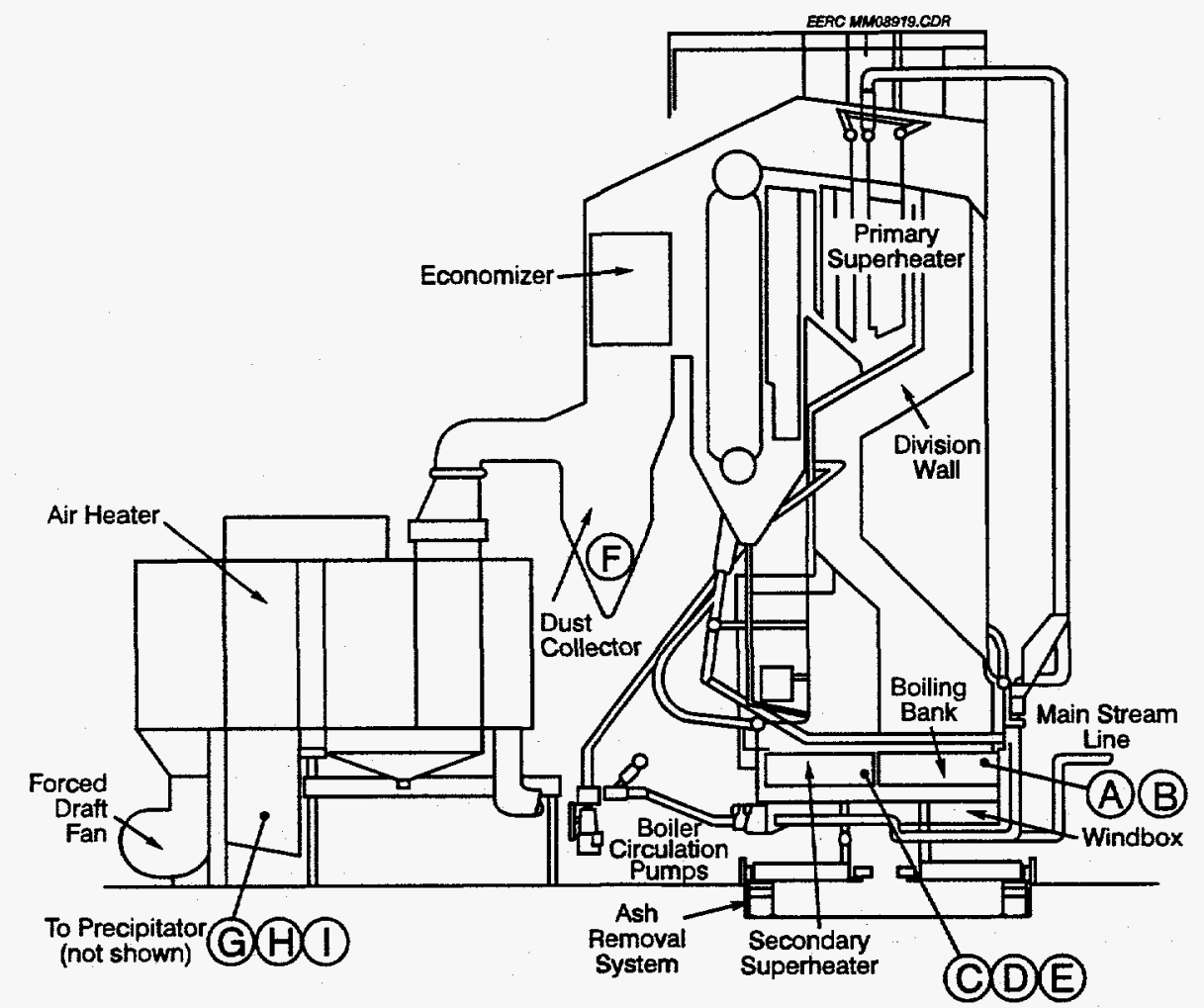

Figure 3-2. Location of run-time samples collected by MDU personnel on March 3, 1993. 
TABLE 3-1

End-of-Test Deposit Samples Collected by EERC Personnel on March 24, 1993

\begin{tabular}{rrl} 
Sample Number & \multicolumn{1}{c}{ Location } \\
\hline 2 & $1^{1}$ & Compartment B tube surface deposit \\
4 & 2 & Compartment B bed tube support deposit \\
1 & 3 & Compartment D tube surface deposit \\
3 & 4 & Compartment D bed tube support deposit \\
26 & 5 & Large agglomerates removed from boiling bank division wall by \\
& & MDU personnel \\
15 & 6 & Division wall deposit below primary superheater \\
12 & 7 & Primary superheater deposits on pendants above nose cone \\
14 & 8 & Primary superheater front side deposit \\
13 & 9 & Primary superheater deposit on second bank anchors \\
16 & 10 & Primary superheater bridging material between tubes \\
9 & 11 & Primary superheater deposit next to mud dru \\
8 & 12 & Boiling bank next to mud drum \\
6 & 13 & Boiling bank near steam drum \\
5 & 14 & Economizer deposit near top \\
7 & 15 & Economizer deposit near middle \\
11 & 16 & Agglomerated cinder from dust collector \\
12 & 17 & Deposit from second section of air heater
\end{tabular}

${ }^{1}$ Numbers refer to sampling locations shown in Figure 3-1.

TABLE 3-2

Run-Time Samples Collected by MDU Personnel on March 3, 1993

\begin{tabular}{lrl} 
Sample Number & & \multicolumn{1}{c}{ Location } \\
\hline 25 & A $^{1}$ & Composite coal ash sample \\
24 & B & Bed material (sand) sample \\
17 & C & Bed drain material, Compartments B and C \\
18 & D & Bed drain material, Compartment A \\
19 & E & Bed agglomerates, Compartment A \\
20 & F & Cyclone dust from hopper \\
21 & G & Electrostatic precipitator (ESP) dust - first row \\
& & precipitator \\
22 & H & ESP dust - second row precipitator \\
23 & I & ESP dust - third row precipitator
\end{tabular}

${ }^{1}$ Letters refer to sampling locations shown in Figure 3-2. 


\subsubsection{Northern States Power Company}

A number of samples have been supplied by Northern States Power Company (NSP) from Black Dog Station. Unit 2 was converted by Foster Wheeler to an atmospheric fluidizedbed combustion boiler, operational in July of 1986 . The boiler operates at $1550^{\circ} \mathrm{F}$ and has a design output of $130 \mathrm{MWe}$.

Samples were collected by plant personnel on January 19,1995, during a scheduled shutdown, including three types of bed agglomerates, bed material, and deposits from the main cell tube brackets, finishing superheater, and multiclone inlet vanes. Another set of samples included two types of bed agglomerates and loose bed material from an unsuccessful start-up attempt in February.

\subsection{Results of Bulk Chemistry Analyses}

\subsubsection{Montana-Dakota Utilities}

The coal fired at the Heskett Station is a Great Plains lignite from the Beulah, North Dakota, mine. The proximate and ultimate analysis data presented in Table 3-3 show that the fuel is a typical North Dakota lignite. Table 3-4 shows the results of the analyses of the fuel ash. Of particular interest is the relatively high (6.4\%) sodium oxide content in this ash. High concentrations of alkaline earth elements in coal have been linked to a number of ash-related problems, including fouling of convective pass tubes in pc-fired boilers, grate clinkering and heat-transfer surface fouling in stokers, and deposition and agglomeration in FBCs.

Table 3-5 shows the composition of the minerals in the test fuel. Of particular interest is the high pyrite concentration. Pyrite can participate in low-temperature reactions. Also of importance is the relatively high quantity of very small particle size mineral species. Over $40 \%$ of the minerals are less than $\mathbf{1 0}$ microns in size, making them available for chemical reactions.

Table 3-6 provides more detail as to the nature of the nonorganic material in the coal. The chemical fractionation procedure shows that $55 \%$ of the calcium, $69 \%$ of the magnesium, $98 \%$ of the sodium, and $69 \%$ of the potassium are associated with the water in the coal or with the carboxylic acid functional groups of the coal. Elements present in the coal in this fashion will produce either very fine particles or vapor during combustion of the coal.

Each of the deposit and agglomerate samples collected was analyzed by $\mathrm{x}$-ray fluorescence analysis (XRFA) for elemental composition. These results are summarized in Table 3-7. There are several trends in these data that become more obvious when the data from Table 3-7 are presented graphically. Figure 3-3 shows elemental data for each of the deposits collected during the sampling trip. From the graph, it can be seen that the in-bed deposits (Samples 1-4) are similar to the other deposits. It also becomes apparent that the deposits that formed on the uncooled surfaces (Samples 2, 4, 5, and 9) and the ash cinder from the dust collector are high in iron. Another trend is an increase in $\mathrm{CaO}, \mathrm{Na}_{2} \mathrm{O}$, and $\mathrm{MgO}$ contents from the front to the back of the boiler (Samples 6-17). 
TABLE 3-3

Proximate and Ultimate Analysis of Beulah Lignite Coal Used at the Heskett Station

Sample Number 47885411

Proximate Analysis, wt $\%, \mathrm{mf}^{4}$

Volume Matter

44.32

Fixed Carbon

42.42

Ash

13.26

Ultimate Analysis, wt\%, $\mathrm{mf}$

Hydrogen

4.23

Carbon

62.84

Nitrogen

0.69

Sulfur

1.98

Oxygen, diff.

17.01

Ash

13.26

Heating Value, Btu/lb, mf

10,752

${ }^{1}$ Moisture-free.

TABLE 3-4

X-Ray Fluorescence Analysis of the Ash from the Beulah Lignite Coal Used at the Heskett Station

\begin{tabular}{|c|c|c|}
\hline \multicolumn{3}{|c|}{ Sample Number 47885411} \\
\hline & \multicolumn{2}{|c|}{ High-Temperature Ash Results, \% of Ash } \\
\hline & Normalized & $\mathrm{SO}_{3}$-Free \\
\hline $\mathrm{SiO}_{2}$ & 18.6 & 23.6 \\
\hline $\mathrm{Al}_{2} \mathrm{O}_{3}$ & 8.6 & 11.0 \\
\hline $\mathrm{Fe}_{2} \mathrm{O}_{3}$ & 16.8 & 21.3 \\
\hline $\mathrm{TiO}_{2}$ & 0.2 & 0.3 \\
\hline $\mathrm{P}_{2} \mathrm{O}_{5}$ & 0.2 & 0.3 \\
\hline $\mathrm{CaO}$ & 19.6 & 25.0 \\
\hline $\mathrm{MgO}$ & 8.0 & 10.1 \\
\hline $\mathrm{Na}_{2} \mathrm{O}$ & 6.4 & 8.1 \\
\hline $\mathrm{K}_{2} \mathrm{O}$ & 0.4 & 0.4 \\
\hline $\mathrm{SO}_{3}$ & 21.3 & 0.0 \\
\hline Total & 100.1 & 100.1 \\
\hline
\end{tabular}

The elemental composition of the run-time samples collected are shown graphically in Figure 3-4. From this figure and the data in Table 3-7, it is noted that the chemistry of the spent bed material (Samples 3 and 4) and agglomerates (Sample 5) are influenced by both the coal ash and the virgin bed material composition. The cyclone ash (Sample 6), on the other hand, is similar in composition to the coal ash, indicating very little carryover of bed material. 
TABLE 3-5

Summary of CCSEM Results for Heskett Station Beulah

Lignite Coal, wt\% on a mineral basis

\begin{tabular}{lrrrrrrr}
\hline Particle-Size & $1.0-$ & $2.2-$ & $4.6-$ & $10.0-$ & $22.0-$ & $46.0-$ & \\
Distribution, $\mu \mathrm{m}$ & 2.2 & 4.6 & 10.0 & 22.0 & 46.0 & 100.0 & Total \\
\hline Quartz & 2.9 & 3.6 & 3.7 & 5.4 & 1.4 & 0.6 & 17.6 \\
Iron Oxide & 0.5 & 0.3 & 0.1 & 0.0 & 0.0 & 0.0 & 0.9 \\
Rutile & 0.1 & 0.0 & 0.0 & 0.0 & 0.0 & 0.0 & 0.1 \\
Calcite & 0.1 & 0.4 & 0.1 & 0.4 & 0.4 & 0.0 & 1.4 \\
Kaolinite & 2.0 & 4.6 & 2.2 & 1.3 & 0.2 & 0.7 & 11.0 \\
Montmorillonite & 0.5 & 0.7 & 0.4 & 0.6 & 0.0 & 0.0 & 2.2 \\
K Al-Silicate & 0.2 & 0.3 & 0.2 & 0.0 & 0.1 & 0.0 & 0.8 \\
Ca Al-Silicate & 0.1 & 0.1 & 0.0 & 0.0 & 0.0 & 0.0 & 0.2 \\
Na Al-Silicate & 0.1 & 0.0 & 0.0 & 0.2 & 0.0 & 0.0 & 0.3 \\
Aluminosilicate & 0.2 & 0.2 & 0.1 & 0.2 & 0.0 & 0.0 & 0.7 \\
Mixed Al-Silicate & 0.1 & 0.0 & 0.0 & 0.0 & 0.0 & 0.0 & 0.1 \\
Ca Silicate & 0.0 & 0.1 & 0.0 & 0.0 & 0.0 & 0.0 & 0.1 \\
Pyrite & 2.5 & 2.9 & 6.1 & 9.0 & 18.6 & 15.5 & 54.6 \\
Oxidized Pyrrho. & 0.1 & 0.0 & 0.0 & 0.0 & 0.0 & 0.0 & 0.1 \\
Gypsum & 0.1 & 0.0 & 0.0 & 0.0 & 0.0 & 0.0 & 0.1 \\
Barite & 0.4 & 0.5 & 0.6 & 0.9 & 0.3 & 0.0 & 2.7 \\
Ca-Al-P & 0.4 & 1.1 & 0.0 & 0.0 & 0.0 & 0.0 & 1.5 \\
Gypsum-Barite & 0.1 & 0.1 & 0.0 & 0.0 & 0.0 & 0.0 & 0.2 \\
Gyp.-Al-Silicate & 0.2 & 0.0 & 0.0 & 0.0 & 0.0 & 0.0 & 0.2 \\
Si-Rich & 0.2 & 1.1 & 0.7 & 0.0 & 0.0 & 0.0 & 2.0 \\
Unknown & 1.6 & 0.9 & 0.0 & 0.5 & 0.2 & 0.0 & 3.2 \\
Total & 12.4 & 16.9 & 14.2 & 18.5 & 21.2 & 16.8 & 100.0 \\
\hline Computer-Controlled
\end{tabular}

1 Computer-controlled scanning electron microscopy.

TABLE 3-6

Chemical Fractionation Results of the Beulah Lignite Coal Used at the Heskett Station Beulah Lignite Coal, wt $\%^{1}$

\begin{tabular}{lrcccc}
\hline & $\begin{array}{c}\text { Initial, } \\
\text { ppm }\end{array}$ & $\begin{array}{c}\text { Water- } \\
\text { Associated }\end{array}$ & $\begin{array}{c}\text { Organic } \\
\text { Acid } \\
\text { Groups }\end{array}$ & $\begin{array}{c}\text { Carbonate and } \\
\text { Coordination } \\
\text { Complexes }\end{array}$ & $\begin{array}{c}\text { Insoluble } \\
\text { Minerals }\end{array}$ \\
\hline Silicon & 8927 & 0 & 0 & 0 & 100 \\
Aluminum & 4681 & 0 & 0 & 1 & 99 \\
Iron & 12,072 & 13 & 0 & 0 & 87 \\
Titanium & 0 & 0 & 0 & 0 & 100 \\
Phosphorus & 94 & 0 & 0 & 0 & 100 \\
Calcium & 14,493 & 8 & 47 & 42 & 3 \\
Magnesium & 4945 & 41 & 28 & 27 & 4 \\
Sodium & 4883 & 0 & 98 & 0 & 2 \\
Potassium & 269 & 69 & 0 & 3 & 28 \\
\hline
\end{tabular}

${ }^{1}$ Results are expressed with silicon loss normalized to zero. 
TABLE 3-7

XRF/Elemental Analysis of Heskett Station Samples

\begin{tabular}{|c|c|c|c|c|c|c|c|c|c|c|c|c|c|c|c|c|c|}
\hline \multicolumn{18}{|c|}{ Run Time Samples Collected by MDU Personnel on 3-3-93 (including casl ash and sand analysis) } \\
\hline & $\begin{array}{l}\text { Presh } \\
\text { Sand }\end{array}$ & Coal & $\begin{array}{l}\text { Bed } \\
\text { Draid }\end{array}$ & $\begin{array}{c}\text { Bed } \\
\text { Drain }\end{array}$ & Aggl.' & $\begin{array}{l}\text { Cyclone } \\
\text { Ash }\end{array}$ & $\begin{array}{l}\text { ESP-1 } \\
\text { Ash }\end{array}$ & $\begin{array}{l}\text { ESP-2 } \\
\text { Ash_ }\end{array}$ & $\begin{array}{l}\text { ESP-3 } \\
\text { Ash }\end{array}$ & & & & & & & & \\
\hline Location: & A & $\mathrm{B}$ & C & $\overline{\mathrm{D}}$ & $\mathrm{E}$ & $\mathrm{F}$ & G & $\overline{\mathrm{H}}$ & $\bar{I}$ & & & & & & & & \\
\hline Sample Number: & 1 & 2 & 3 & 4 & 5 & 6 & 7 & 8 & 9 & & & & & & & & \\
\hline Sampole Number: & 25 & 24 & 17 & 18 & 19 & 20 & 21 & 22 & 23 & & & & & & & & \\
\hline \multicolumn{18}{|l|}{ Oxide, wt\% } \\
\hline $\mathrm{SiO}_{2}$ & 66.7 & 18.6 & 59.2 & 59.2 & 54.7 & 35.6 & 21.9 & 24.2 & 17.8 & & & & & & & & \\
\hline $\mathrm{Al}_{2} \mathrm{O}_{3}$ & 7.7 & 8.6 & 7.6 & 8.7 & 10.4 & 14.4 & 11.0 & 11.7 & 9.4 & & & & & & & & \\
\hline $\mathrm{Fe}_{2} \mathrm{O}_{3}$ & 5.3 & 16.8 & 7.0 & 7.5 & 10.6 & 13.4 & 6.6 & 6.6 & 6.4 & & & & & & & & \\
\hline $\mathrm{P}_{2} \mathrm{O}_{3}$ & 0.1 & 0.2 & 0.0 & 0.2 & 0.1 & 0.2 & 0.6 & 0.6 & 0.5 & & & & & & & & \\
\hline $\mathrm{CaO}$ & 14.8 & 19.6 & 12.6 & 10.4 & 13.4 & 17.3 & 26.1 & 25.6 & 27.3 & & & & & & & & \\
\hline $\mathrm{MgO}$ & 3.2 & 8,0 & 3.8 & 2.2 & 2.9 & 4.3 & 6.6 & 6.5 & 7.1 & & & & & & & & \\
\hline $\mathrm{Na}_{2} \mathrm{O}$ & 1,4 & 6.4 & 3.6 & 4.5 & 2.9 & 2.3 & 6.4 & 5,6 & 7.9 & & & & & & & & \\
\hline $\mathrm{K}_{2} \mathrm{O}$ & 0.6 & 0.4 & 0.5 & 0.5 & 1.5 & 1.2 & 0,6 & 0.6 & 0.6 & & & & & & & & \\
\hline $\mathrm{SO}_{3}$ & 0.2 & 21.3 & 5.6 & 6.6 & 3.6 & 11.3 & 20.3 & 18.7 & 23.0 & & & & & & & & \\
\hline Total & 100.0 & 100.0 & 100.0 & 100.0 & 100.0 & 100.0 & 100.0 & 100.0 & 100.0 & & & & & & & & \\
\hline \multicolumn{18}{|l|}{ Element ratios } \\
\hline $\mathrm{Ca}: \mathrm{S}$ & 91.99 & 1,32 & 3.19 & 2.25 & 5.33 & 2.18 & 1.84 & 1.95 & 1.69 & & & & & & & & \\
\hline Alkali:S & 101,69 & 1.72 & 4,08 & 3.20 & 6.71 & 2.54 & 2.27 & 2.37 & 2.16 & & & & & & & & \\
\hline $\mathrm{Ca}: \mathrm{Na}$ & 12,05 & 3.40 & 3.89 & 2.54 & 5,18 & 8.25 & 4.52 & 5,06 & 3.80 & & & & & & & & \\
\hline Base:Acid & 0.34 & 1.86 & 0.41 & 0.37 & 0.48 & 0.77 & 1.39 & 1.23 & 1.78 & & & & & & & & \\
\hline $\mathrm{Ca}: \mathrm{Mg}$ & 3.35 & 1.78 & 2,39 & 3,34 & 3.30 & 2.93 & 2.83 & 2.83 & 2.79 & & & & & & & & \\
\hline $\mathrm{Ca}: \mathrm{Si}$ & 0,24 & 1.13 & 0.23 & 0.19 & 0.26 & 0.52 & 1.28 & 1.13 & 1.65 & & & & & & & & \\
\hline \multicolumn{18}{|c|}{ End-of-Test Deposit Samples Arranged from Bed to Exit of FBC } \\
\hline & \multicolumn{4}{|c|}{ Bed Tube Deposils } & \multicolumn{2}{|c|}{ Division Wall } & \multicolumn{5}{|c|}{ Superheater } & \multicolumn{4}{|c|}{ Fenomizer } & Clinker & Hester \\
\hline Point Number: & 1 & 2 & 3 & $\overline{4}$ & 5 & 6 & 7 & 8 & 9 & 10 & $\overline{11}$ & 12 & 13 & 14 & 15 & 16 & 17 \\
\hline Sample Number: & 2 & 4 & 1 & 3 & 26 & 15 & 12 & 14 & 13 & 16 & 9 & 8 & 6 & 5 & 7 & 11 & 10 \\
\hline \multicolumn{18}{|l|}{ Oxide, wt\% } \\
\hline $\mathrm{SiO}_{2}$ & 8.8 & 8.0 & 8.9 & 10.0 & 4.9 & 6.3 & 10.2 & 10.1 & 9.5 & 12.9 & 9.6 & 11.3 & 8.2 & 7.0 & 8.3 & 51.6 & 17.0 \\
\hline $\mathrm{Al}_{2} \mathrm{O}_{3}$ & 5.6 & 4.7 & 5.6 & 4.4 & 3.8 & 4.9 & 5.5 & 6.2 & 5.9 & 6.3 & 5.8 & 5.8 & 5.7 & 6.1 & 6.6 & 10.1 & 8.7 \\
\hline $\mathrm{Fe}_{2} \mathrm{O}_{3}$ & 7.1 & 14.0 & 7.3 & 11.2 & 38.8 & 27.6 & 8.2 & 5.6 & 11.9 & 3.8 & 4.6 & 5.8 & 4.6 & 3.9 & 4.4 & 7.3 & 7.3 \\
\hline $\mathrm{P}_{2} \mathrm{O}_{3}$ & 0.2 & 0.2 & 0.2 & 0.1 & 0.0 & 0.1 & 0.3 & 0.3 & 0.2 & 0.4 & 0.3 & 0.3 & 0.4 & 0.5 & 0.6 & 0.2 & 0.6 \\
\hline $\mathrm{CaO}$ & 27.0 & 21.8 & 26.3 & 20.8 & 17.1 & 18.6 & 20.8 & 20.0 & 18.8 & 17.8 & 19.1 & 21.8 & 23.3 & 23.3 & 26.4 & 19.1 & 28.4 \\
\hline $\mathrm{MgO}$ & 5.3 & 2.9 & 5.2 & 3.5 & 4.2 & 3.1 & 3.5 & 3.2 & 2.7 & 4.5 & 5.0 & 5.6 & 5.1 & 5.6 & 6.2 & 3.5 & 8.9 \\
\hline $\mathrm{Na}_{2} \mathrm{O}$ & 5.9 & 7.3 & 6.1 & 9.2 & 3.3 & 3.6 & 5.6 & 8.9 & 9.7 & 5.6 & 7.2 & 7.9 & 7.6 & 9.4 & 5.8 & 3.2 & 4.0 \\
\hline $\mathrm{K}_{2} \mathrm{O}$ & 0.8 & 0.7 & 0.8 & 0.9 & 0.3 & 0.5 & 0.8 & 0.9 & 0.8 & 0.8 & 1.1 & 1.1 & 0.6 & 0.6 & 0.4 & 0.3 & 0.4 \\
\hline $\mathrm{SO}_{3}$ & 39.5 & 40.5 & 39.5 & 39.8 & 27.6 & 35.4 & 45.0 & 44.9 & 40.5 & 48.0 & 47.4 & 40.4 & 44.6 & 43.7 & 41.4 & 4.8 & 24.7 \\
\hline Total & 100.0 & 100.0 & 100.0 & 100.0 & 100.0 & 100.0 & 100.0 & 100.0 & 100.0 & 100.0 & 100.0 & 100.0 & 100.0 & 100.0 & 100.0 & 100.0 & 100.0 \\
\hline \multicolumn{18}{|l|}{ Element Ratios } \\
\hline Ca:S & 0.97 & 0.77 & 0.95 & 0.75 & 0.88 & 0.75 & 0.66 & 0.64 & 0.66 & 0.53 & 0.58 & 0.77 & 0.75 & 0.76 & 0.91 & 5.72 & 1.64 \\
\hline Alkali:S & 1.18 & 1.02 & 1.17 & 1.06 & 1.05 & 0.89 & 0.84 & 0.91 & 0.99 & 0.69 & 0.79 & 1.05 & 0.98 & 1.05 & 1.10 & 6.65 & 1.86 \\
\hline $\mathrm{Ca}: \mathrm{Na}$ & 5.07 & 3.30 & 4.76 & 2.50 & 5.67 & 5.76 & 4.11 & 2.49 & 2.14 & 3.53 & 2.95 & 3.07 & 3.37 & 2.76 & 5.00 & 6.59 & 7,93 \\
\hline Base:Acid & 3.14 & 3.63 & 3,11 & 3.13 & 7.38 & 4.74 & 2.44 & 2.32 & 2.81 & 1.66 & 2.35 & 2.42 & 2.90 & 3.15 & 2.80 & 0.54 & 1.87 \\
\hline Ca:Mg & 3,68 & 5.43 & 3.63 & 4.23 & 2.94 & 4.27 & 4.23 & 4.53 & 5.00 & 2.84 & 2.78 & 2.81 & 3.28 & 3.01 & 3.07 & 3.89 & 2.29 \\
\hline $\mathrm{Ca}: \mathrm{Si}$ & 3.28 & 2.92 & 3.16 & 2.23 & 3.74 & 3.19 & 2.18 & 2.13 & 2.11 & 1.48 & 2.14 & 2.07 & 3.05 & 3.58 & 3.41 & 0.40 & 1.79 \\
\hline
\end{tabular}

'Agglomerates. 


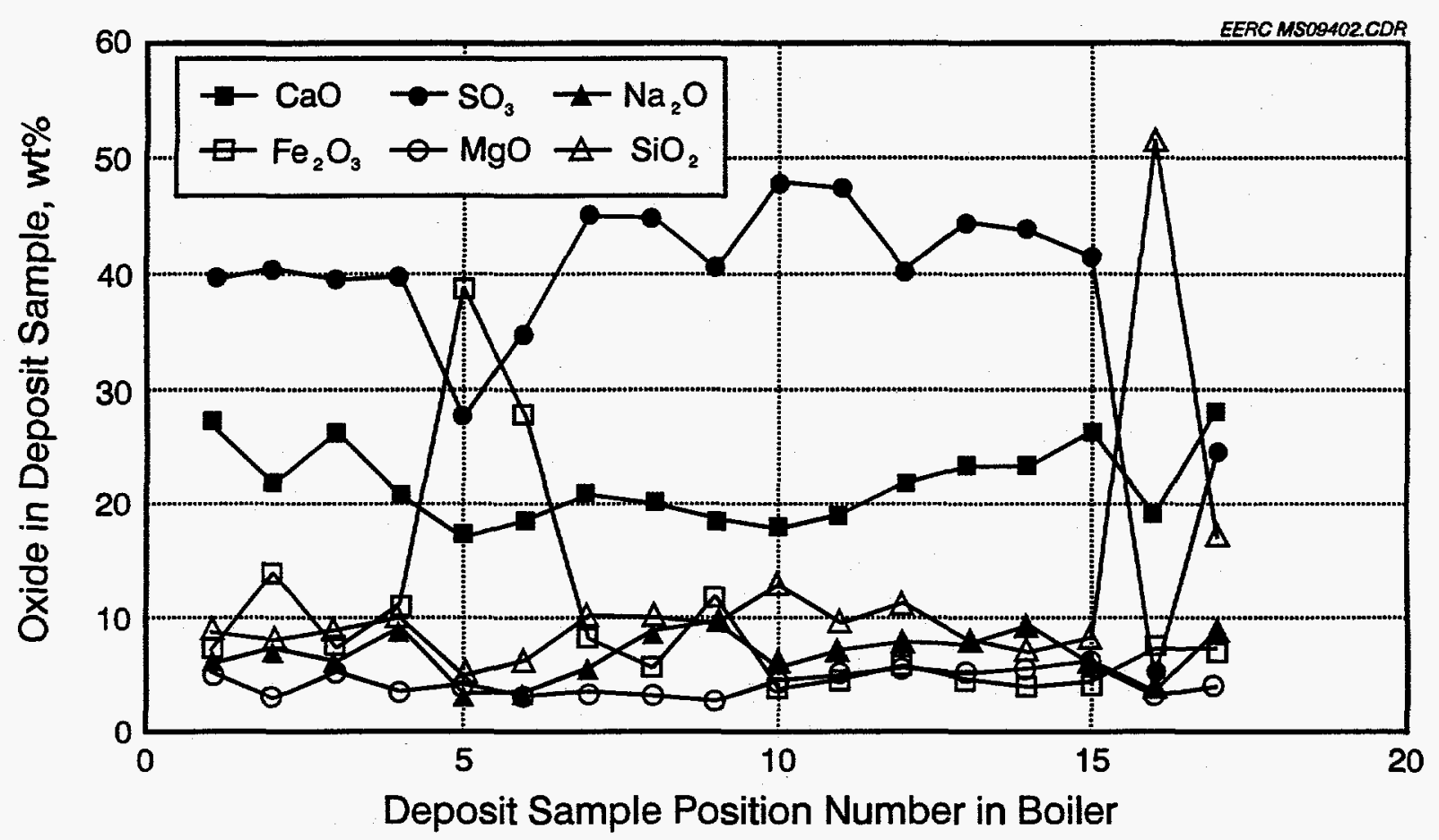

Figure 3-3. Comparison of deposits collected from the Heskett Station (refer to Table 3-1 for a position description of Samples 1-17).

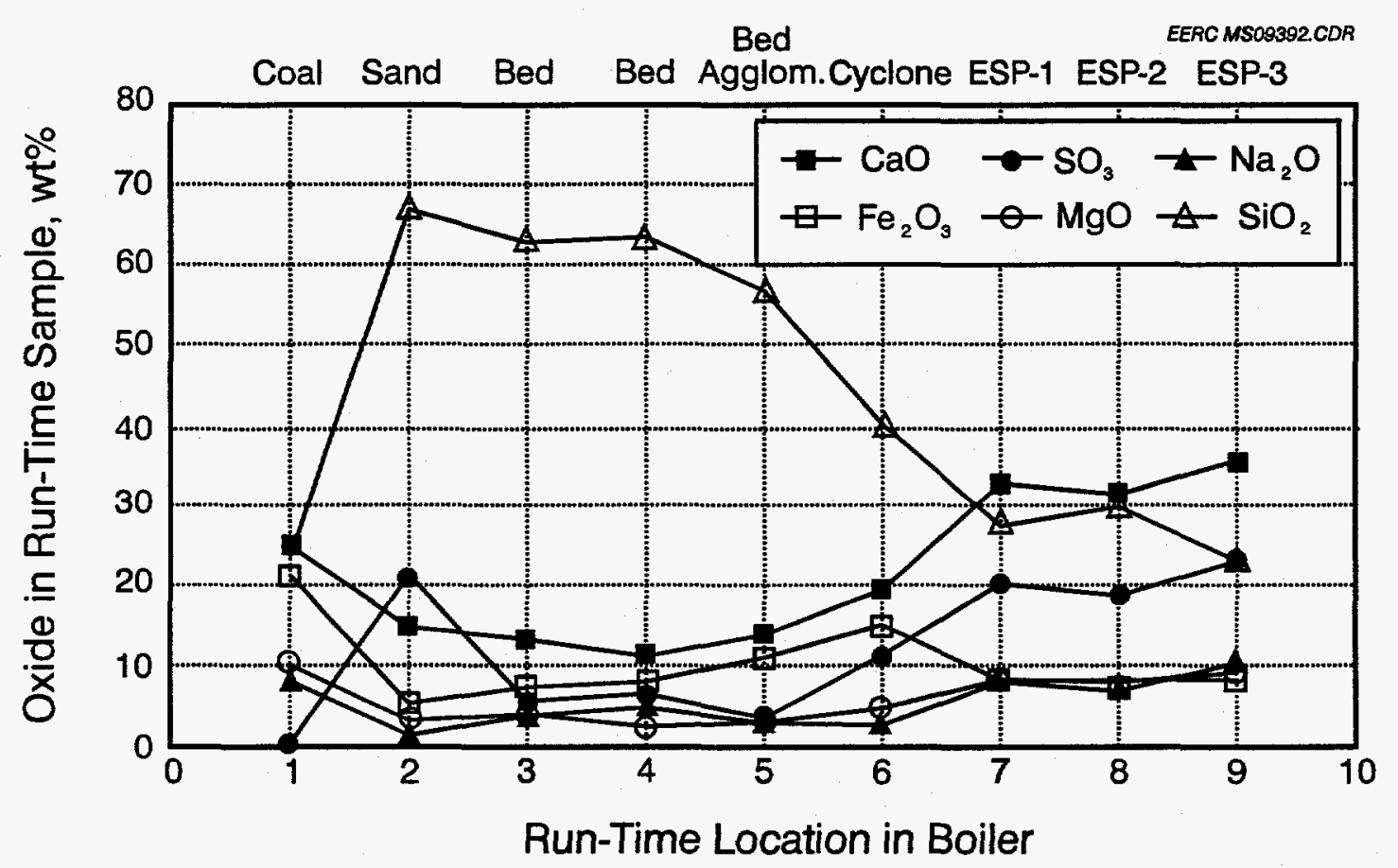

Figure 3-4. Comparison of run-time samples collected from the Heskett Station (position of Samples 1-9 refers to Locations A-I in Table 3-2). 
The ESP ash (Samples 7-9) was very high in alkali sulfates, indicating that the alkali and alkaline earth elements formed sulfate particles that were smaller those from the other mineral present in the raw coal or the virgin bed material.

The composition of the bed material taken from Compartments B and C (Sample 3) are the same as that from Compartment $\mathrm{A}$ (Sample 4). Compartment $\mathrm{A}$ is turned on and off to follow the load, while Compartments $B$ and $C$ are always on line.

Other observations are made in Figure 3-5 which compares deposits from the major parts of the boiler to the coal ash. This figure shows an enrichment of iron for front-end deposits. The Gaussian distribution of sulfur content indicates that the temperature at the back end was too low for sulfation to occur. The calcium content of the deposits increased toward the back end of the boiler because of segregation of the fines in the boiler.

When the compositions of the ash streams are compared to the deposits (as shown in Figure 3-6), several other trends become apparent. The high $\mathrm{SO}_{3}$ concentration in the deposit relative to the ash indicates that the deposits were being sulfated in place. Iron was present in the coarser cyclone ash as compared to the ESP ash, indicating that it was falling out in the front part of the boiler. The alkali metals and sulfur are at higher levels in the ESP ash as compared to the coarse cyclone ash, indicating that the organically bound cations do indeed form fine sulfate particles and that these particles are present in all parts of the boiler.

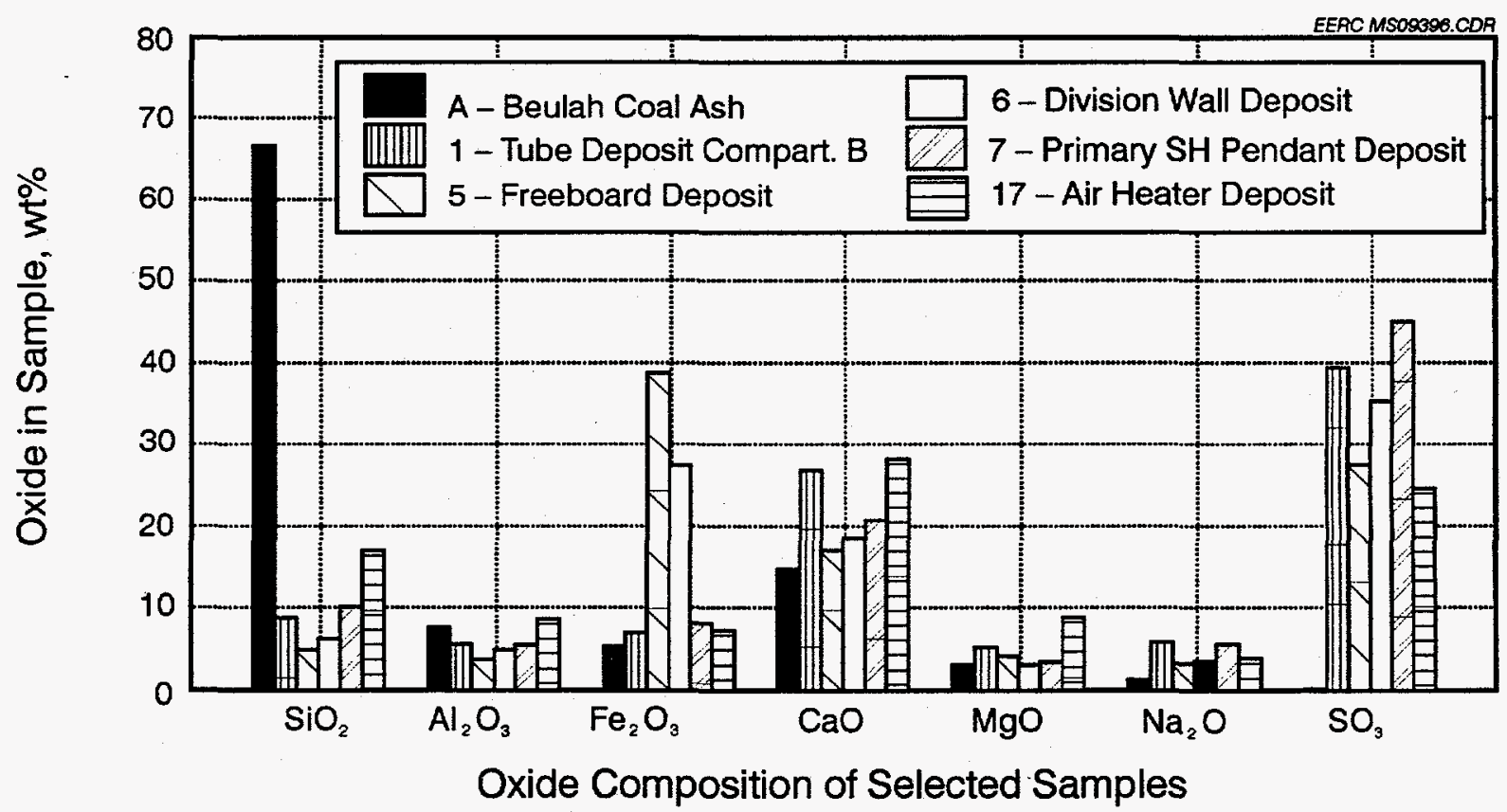

Figure. 3-5. Comparison of deposit and coal ash chemistry for various locations in the Heskett Station. 


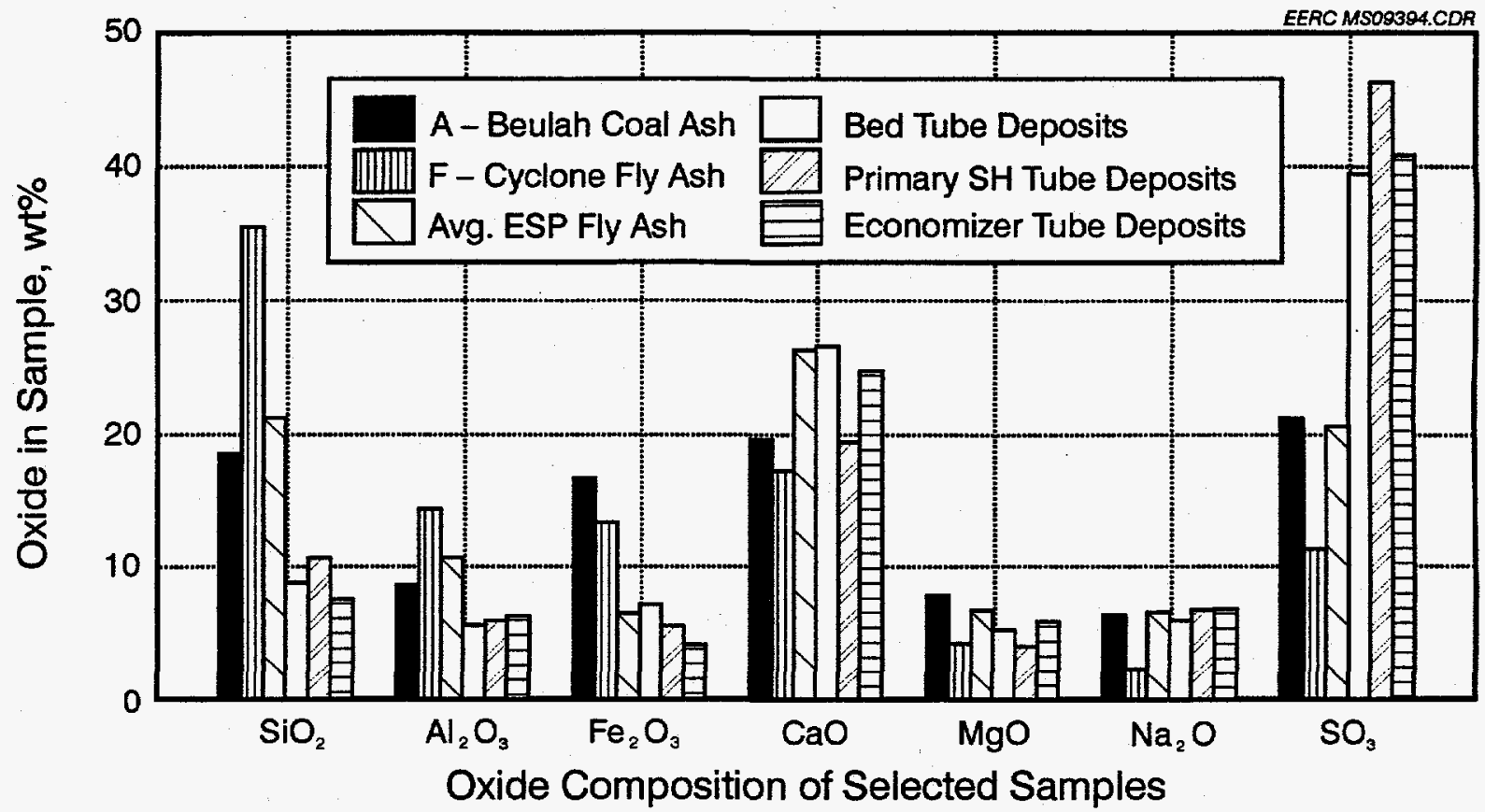

Figure 3-6. Comparison of deposit and fly ash chemistry from the Heskett Station.

Figure 3-7 compares only the run-time samples. It can be seen that cyclone ash chemistry is influenced by the bed material as well as the coal ash. This chemistry could have an influence on the formation mechanism of the deposits. It is noted here again that the calcium, magnesium, sodium, and sulfur concentrations increase toward the back of the boiler.

Figure 3-8 concentrates on the chemistry of the bed material and bed deposits. It is seen that the coal, bed material, and in-bed deposits have distinctly different chemistry. The deposits are influenced primarily by the coal ash, with the bed material apparently not playing a role in the deposit formation. Calcium and sulfur are enriched in the deposits as compared to the quantities present in the parent coal.

In summary, the coal used at the Heskett Station contains a large percentage of organically bound cations. Approximately $60 \%$ of the calcium, magnesium, and potassium are organically associated, as is virtually all of the sodium. These elements will produce either very fine particles or vapor during the combustion of the coal. The nonorganically associated calcium and magnesium in the coal are present as dolomite.

Mineral content of the coal consists of approximately $55 \%$ pyrite, $18 \%$ quartz, and $11 \%$ kaolinite. Over $40 \%$ of the minerals are less than 10 microns in size, making them available for chemical reactions. 


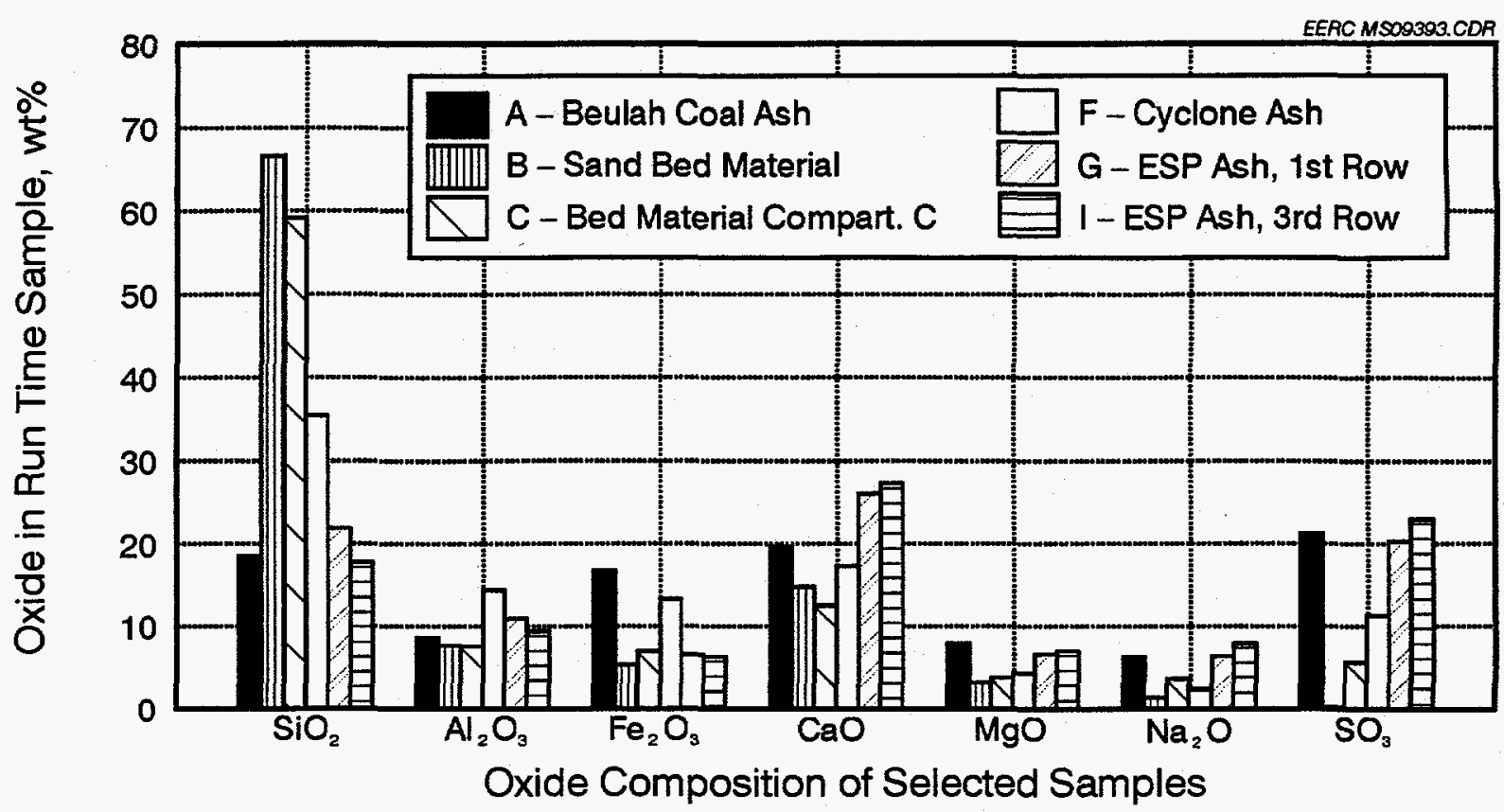

Figure 3-7. Comparison of run-time samples with sampling location for the Heskett Station.

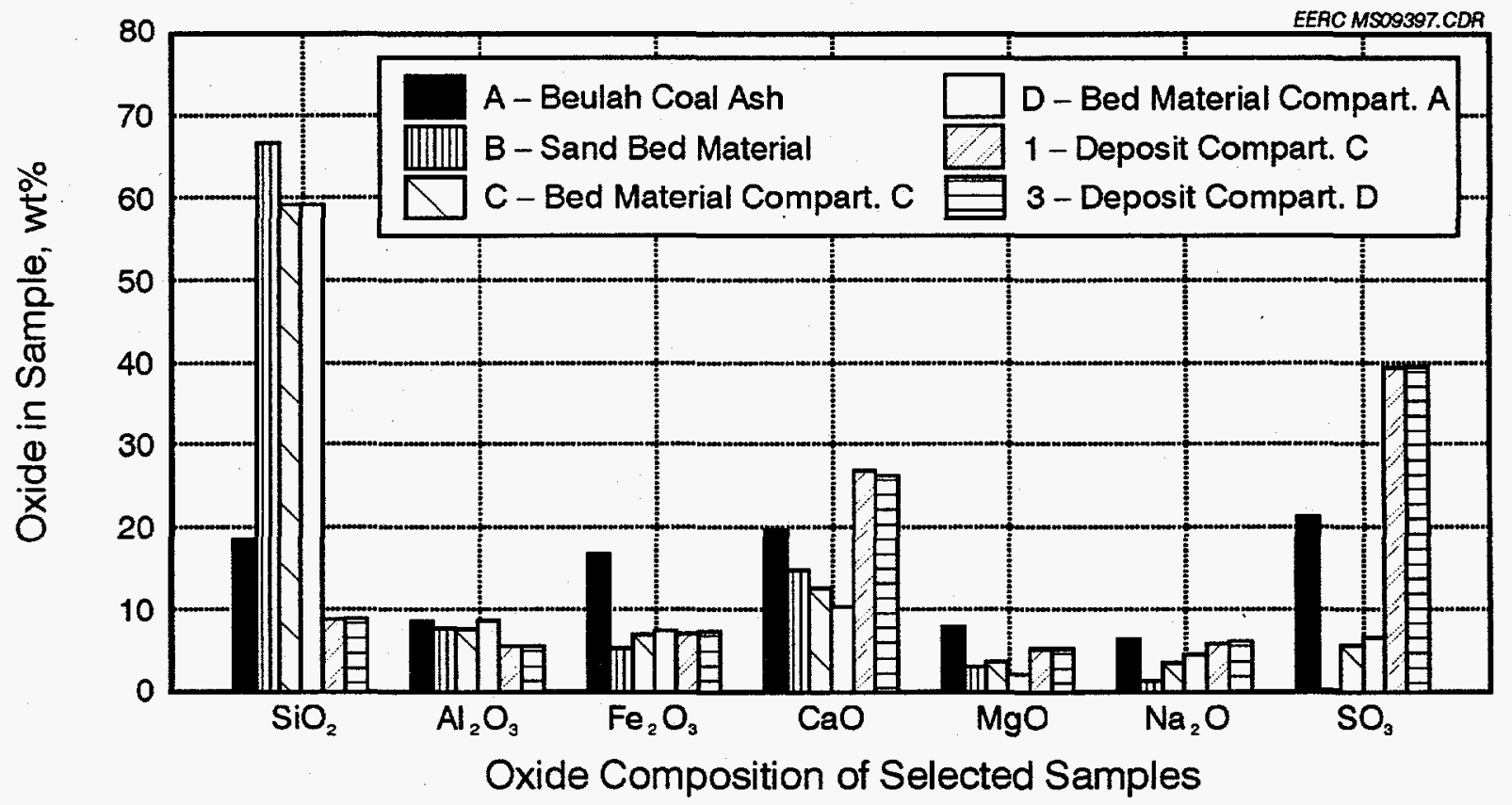

Figure 3-8. Comparison of bed material and bed deposit chemistry from the Heskett Station. 
Iron was concentrated in the coarse particles of the bed and cyclone ash streams. Calcium, sulfur, and sodium were enriched in the fine particles of the ESP ash. The fly ash streams were depleted in quartz and pyrite, while some iron oxides were present in the ash. Although kaolinite was present in the coal, the clay-derived phases in the fly ash had silicon-toaluminum ratios similar to montmorillonite or other complex aluminosilicates (such as sodium aluminosilicates). The silicon-to-aluminum ratio is $1: 1$ for kaolinite vs. 1:3 for fly ash. This reduced silicon content indicates that reactions were occurring that would lower the melting point of the silicates.

$\mathrm{X}$-ray diffraction (XRD) analyses of the bed material and agglomerates showed that the virgin bed material is a mixture of minerals and not a pure silica sand. Relatively high quantities of dolomite, calcite, and plagioclase were identified in addition to that of quartz. The coal ash did influence the final composition of the bed and was present primarily as ash coatings. Sodium, sulfur, and iron were at higher levels in the bulk bed material as compared to the virgin bed material and were later identified as the main constituents of the ash coatings. As compared to the virgin bed, the agglomerates had higher concentrations of iron and calcium and lower levels of sodium and sulfur. Overall, the agglomerates showed similar chemistry to that of the bulk bed material.

The sodium content of the in-bed deposits ranged from $6 \%-9 \%$, while deposits in the superheat, reheat, and economizer sections had $7 \%-10 \%$ sodium. The coal ash, by comparison, contained $6.4 \%$ sodium. The calcium concentrations of the ESP and reheat deposits were $20 \%$ to $25 \%$, while the superheater deposits had $20 \%$ calcium as compared to $20 \%$ calcium in the coal ash. All deposits were high in sulfur, ranging from $40 \%$ to $45 \%$. Deposits from uncooled surfaces were high in iron.

Several important trends were also noted from the determinations of the bulk chemistry. Going from the front (superheater) to the back (ESP) of the boiler, the concentration of sodium increases while calcium content decreases slightly. The silicon, iron, and aluminum concentrations decreased going from front to back. The trend indicated that larger ash particles were falling out in the front part of the boiler, while those organically bound elements that formed fine particles or were vaporized were carried farther back in the system.

The deposits tended to be higher in sodium and sulfur than the corresponding fly ash. The increase in sulfur indicated that the deposits were sulfating after they were deposited, leading to increased strength. The increase in sodium indicated that the sodium was probably present as very fine-grained ash and/or aerosol particles. The calcium-to-sulfur and calcium-tosodium ratios also showed these trends. The deposits and fly ash were also enriched in sodium and sulfur when compared to the coal.

The ratio of calcium to silicon was higher for deposits, again indicating the deposits were sulfate-based. However, the ratio of calcium to magnesium was similar for the coal, fly ash, and deposits, indicating no concentrating effect of the calcium relative to the other alkaline elements. 


\subsubsection{Northern States Power Company}

The coal fired at the NSP Black Dog Station is a western subbituminous from the Sarpy Creek mine. Fouling is not of great concern in this boiler, but serious agglomeration problems exist at start-up and during upset operating conditions. Table 3-8 lists the location and description of each of the samples collected by plant personnel. The samples dated January 19 were collected during a scheduled shutdown; the samples dated February 15 were collected following a failed start-up attempt.

Bulk analyses were performed on the bed material and the deposits. The results of these analyses are shown in Figure 3-9. This figure shows the distinct difference in composition between the bed material and the deposits. The aluminosilicate bed material tends to stay in the bed, while iron and calcium are concentrated further downstream. As seen in the Heskett samples, the high levels of $\mathrm{SO}_{3}$ in the deposits indicate that sulfation is taking place on the tubes.

TABLE 3-8

Samples Collected by NSP Personnel

\begin{tabular}{lcc}
\hline Date Collected & Location & Description \\
\hline Jan. 19, 1995 & South Main Cell Tube Brackets & Deposits \\
& South Main Cell & $\begin{array}{c}\text { Egg-type agglomerate } \\
\text { Sintered agglomerate } \\
\text { Clay rock }\end{array}$ \\
& South Main Cell & Deposits \\
& Main Cell & Spent bed material \\
& South Main Cell & Finishing superheater chips \\
Multiclone Inlet Vanes & Deposit \\
Feb. 15, 1995 & Main Cell & 3 clay-colored agglomerates \\
& 2 large dark-colored agglomerates \\
& Spent bed material \\
\hline
\end{tabular}




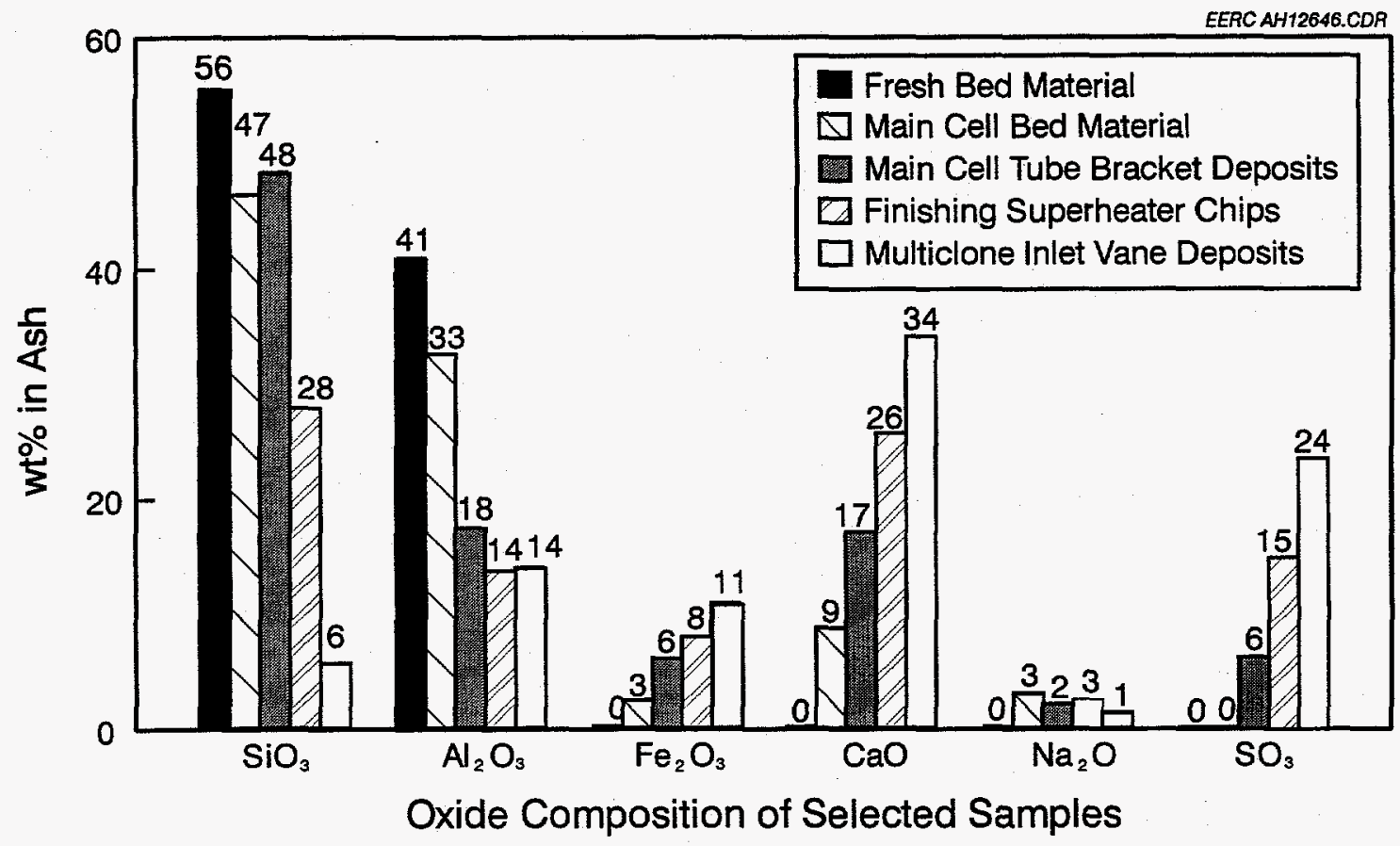

Figure 3-9. Comparison of bed material and bed deposit chemistry from the Black Dog Station.

\subsection{Morphological Examination}

\subsubsection{Montana-Dakota Utilities}

Selected samples were examined using the electron microscope to determine the morphological structure of these materials and the chemical composition of the areas that contributed to deposition and agglomeration. Results from this examination were delivered as Appendix B with the first-year progress report; the important trends are discussed here.

The deposits show a layered structure, indicating that they were formed as a result of different "episodes." This layering may be caused by normal cycling of the boiler or by changes in the coal composition, both of which will impact the size and chemistry of the deposit. The bulk of the deposit material was sulfate-based, primarily calcium, with sodium and magnesium. Mineral inclusions found in the deposits, from the coal and bed material, did not appear to be taking an active role in the deposition process. Some of these were rounded and appeared to have been changed by erosion or other forces.

Division wall deposits located approximately $15 \mathrm{ft}$ above the bed had a high concentration of iron "blebs" in a sulfate matrix. The iron in these deposits was derived from pyrite particles impacting on the tubes. A dendritic growth pattern was noted. These large iron inclusions were not seen in any of the other deposits that formed in the rest of the boiler. 
Based on phase diagrams for a calcium sulfate, sodium sulfate, and magnesium sulfate system, it was determined that the melting points for these sulfate-based phases in the deposits were as low as $1400^{\circ} \mathrm{F}$ for some of the deposits, but were typically in the range of $1700^{\circ}$ to $2000^{\circ} \mathrm{F}$.

The bed was made up of many different mineral phases-quartz, albite, anorthite, calcite, dolomite, and other rock fragments-as shown in the bulk chemistry summary. Therefore, these results should not be directly compared to those derived from a pure silica-sand bed. The spent bed material is coated with a calcium sulfate-based material. It is likely that this coating plays a significant role in the agglomeration process.

In addition to the point count, the bed particles were analyzed with a line scan technique, which provides for chemical analysis along a line drawn across the sample. The results are then shown graphically, as in Figure 3-10, with the strength of the signal for each element analyzed being plotted as a function of distance along the line. This technique is very useful for comparing the chemistry of a coating with the particle itself. The distinct change in chemistry at the interface between coating and bed material indicated that no interaction was occurring between the two.

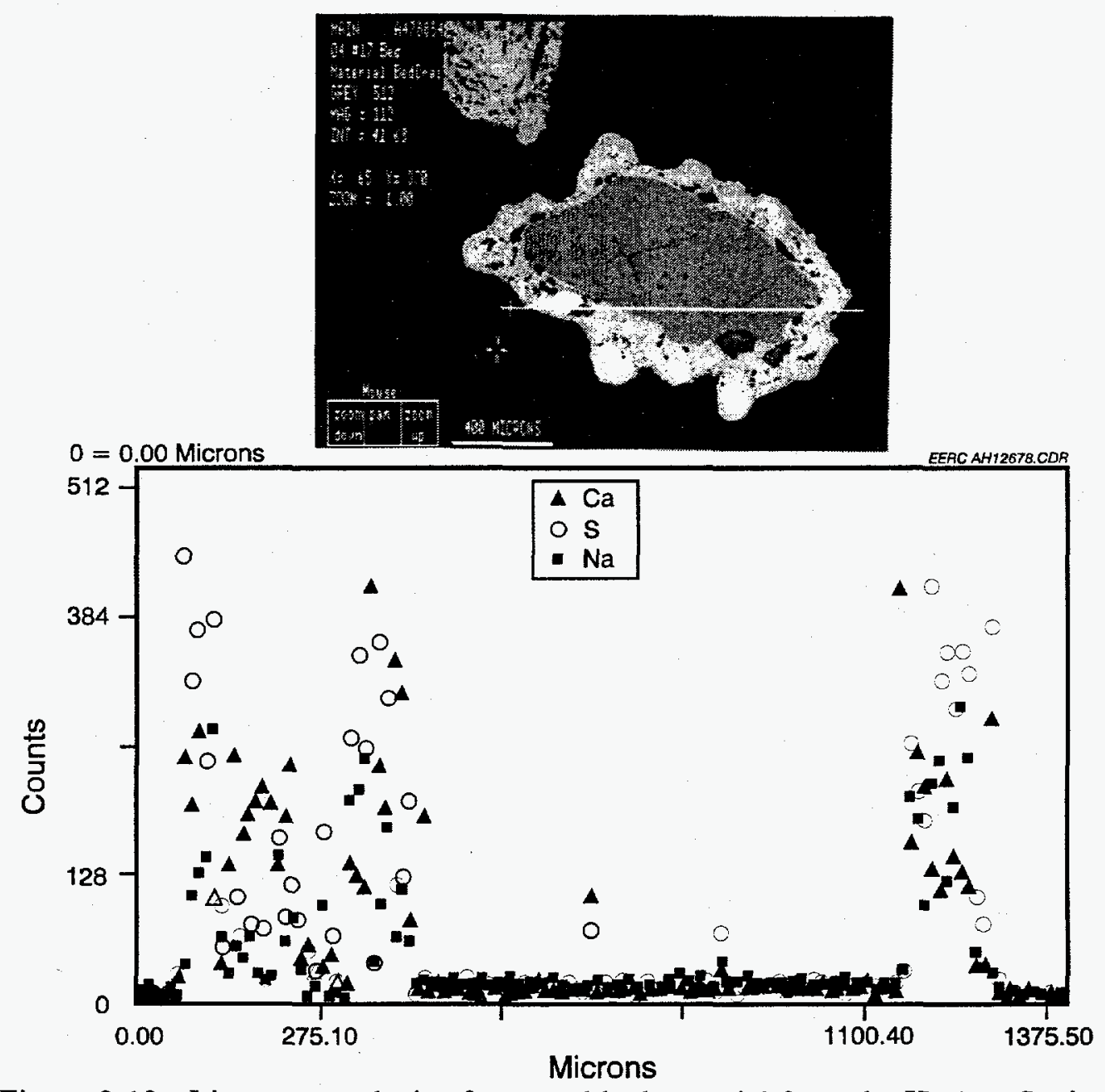

Figure 3-10. Line scan analysis of a coated bed material from the Heskett Station. 
The chemistry of the agglomerate was mainly silicate-based. Several iron, calcium, and magnesium oxide minerals crystallized out from an amorphous (melt) phase. More detailed analysis may indicate the temperature(s) necessary for these phases to form and crystallize. The bulk phase, or glue, consisted of sodium, magnesium, calcium, aluminum, and silicon. This indicated that the glue was a low-melting alkali-aluminosilicate. We are currently looking for suitable phase diagrams to use to study the melting behavior of this system.

The morphological examination has been supplemented with scanning electron microscopy point count (SEMPC) analyses. During a morphological examination, the chemical composition of a few areas selected by the instrument operator is determined, and the SEMPC routine determines the chemical composition of 250 randomly selected points in these areas. To assist in the interpretation of the SEMPC data, a number of element ratios were calculated and compared. Some of the trends from this ratio analysis are presented here.

A change in the calcium-to-sulfur ratio from greater than 1 for the coal and fly ash to less than 1 for the deposits indicated that the ash deposited was only partially sulfated and that sulfation of the ash occurred once the material was deposited. This was seen in the cooler sections of a pcfired boiler and contributed to strength development. Calcium:silicon and base:acid were higher for the deposits than for the coal and fly ash, indicating a sulfate-based rather than a silicate-based deposition. Calcium:sodium, meanwhile, was significantly lower for the deposits than a for the coal and fly ash, indicating that the sodium was concentrating in the deposits. Sodium may be acting as a fluxing agent, lowering the melting point of the deposited material.

\subsubsection{Northern States Power Company}

Several of the Black Dog samples were examined with scanning electron microscopy to determine the morphology of the samples and to analyze the chemical composition of areas which contributed to agglomeration and deposition. The results of these analyses are discussed here.

Many of the bed material particles were coated with a layer of calcium aluminosilicate. Unlike the Heskett bed material, which was coated with a calcium sulfate material, there was virtually no sulfur in the coatings on the Black Dog bed material. No neck growth was observed in the bed material sample analyzed.

In addition to point count analysis, the Black Dog samples were analyzed with line scans. Figure 3-11 shows the sodium line scan for a Black Dog bed material particle. While this type of analysis showed no interaction between coating and bed material for the Heskett samples, the reverse is true of the Black Dog bed material. The line scan revealed the migration of sodium into the bed material particle, particularly in the presence of cracks in the bed particle. Line scans of other elements, such as calcium and magnesium, displayed the same definite break at the particle-coating interface as seen in the Heskett samples. It is assumed that the porosity of the bed material used at Black Dog accounted for the sodium migration.

Two small agglomerates sampled from Black Dog during a scheduled shutdown were found to consist of aluminosilicate particles encased in a matrix of silica, aluminum, and calcium. This matrix differed from the bed material coatings in that it contained much more silica and much less calcium than the coatings. 


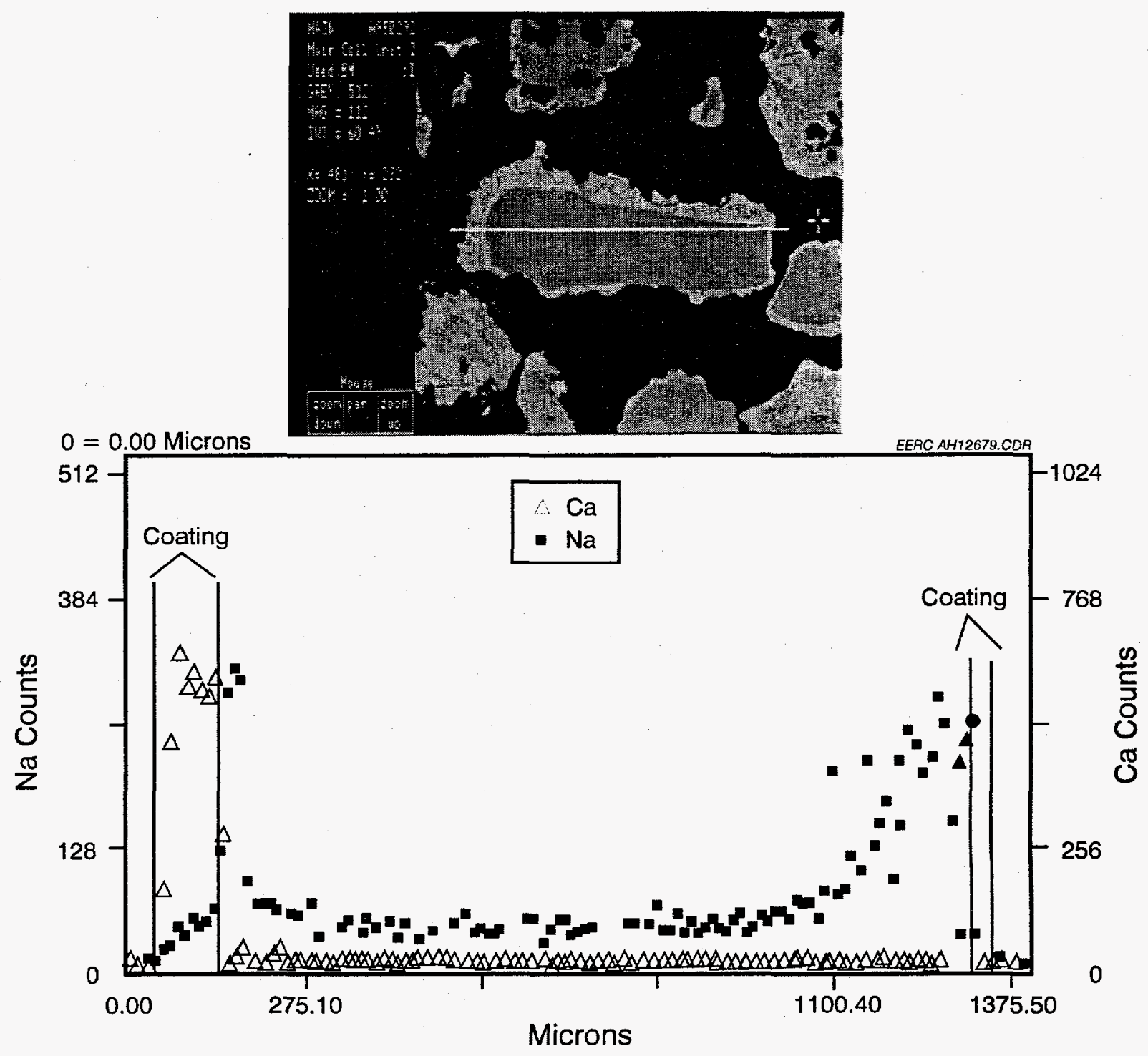

Figure 3-11. Sodium line scan for a Black Dog bed material particle.

A larger bed agglomerate was clay-colored on the outside and reddish on the inside. Several points in the matrix material were examined, starting next to the bed particle and moving outward. Table 3-9 shows the chemistry of each point. The matrix was predominantly aluminum, silica, and calcium, but there was much more variability in this matrix than in the one described above. Moving away from the bed grain from Point 1 to Point 4 , the iron increases dramatically, while Points 5 to 8 contain very little iron. Sodium is prevalent in Points $1,3,6$, and 7 , but there is no trend apparent. 
TABLE 3-9

Oxide Analysis of Selected Points from Clay-Colored Agglomerate

\begin{tabular}{lrrrrrrrr}
\hline $\begin{array}{l}\text { Oxides, } \\
\text { wt\% }\end{array}$ & Point 1 & Point 2 & Point 3 & Point 4 & Point 5 & Point 6 & Point 7 & Point 8 \\
\hline $\mathrm{SiO}_{2}$ & 37.46 & 42.83 & 35.46 & 5.35 & 39.78 & 41.71 & 40.79 & 43.68 \\
$\mathrm{Al}_{2} \mathrm{O}_{3}$ & 40.82 & 34.91 & 20.71 & 56.32 & 27.62 & 34.57 & 33.82 & 34.37 \\
$\mathrm{Fe}_{2} \mathrm{O}_{3}$ & 2.02 & 2.12 & 5.05 & 13.43 & 1.15 & 1.79 & 1.40 & 1.54 \\
$\mathrm{TiO}_{2}$ & 0.77 & 0.41 & 4.40 & 0.34 & 1.85 & 0.57 & 1.44 & 0.51 \\
$\mathrm{P}_{2} \mathrm{O}_{5}$ & 0.00 & 0.00 & 0.85 & 0.18 & 2.06 & 0.00 & 0.00 & 0.00 \\
$\mathrm{CaO}$ & 4.68 & 19.06 & 25.08 & 2.65 & 25.36 & 5.12 & 8.01 & 18.36 \\
$\mathrm{MgO}$ & 0.41 & 0.18 & 1.83 & 20.64 & 0.59 & 0.40 & 0.50 & 0.00 \\
$\mathrm{Na}_{2} \mathrm{O}$ & 12.8 & 0.47 & 5.09 & 0.91 & 1.60 & 14.18 & 12.22 & 0.73 \\
$\mathrm{~K}_{2} \mathrm{O}$ & 1.76 & 0.00 & 1.01 & 0.18 & 0.00 & 1.67 & 1.82 & 0.28 \\
$\mathrm{SO}_{3}$ & 0.00 & 0.00 & 0.52 & 0.00 & 0.00 & 0.00 & 0.00 & 0.19 \\
\hline
\end{tabular}

Note: Point 1 is next to bed material and moves out to Point 4. Point 5 is next to bed material and moves out to Point 8. 


\section{0}

\section{PILOT-SCALE TESTING AT THE EERC}




\section{TABLE OF CONTENTS}

4.0 PILOT-SCALE TESTING AT THE EERC $\ldots \ldots \ldots \ldots \ldots \ldots \ldots \ldots \ldots$ 4-1

4.1 Equipment Used and Test Conditions $\ldots \ldots \ldots \ldots \ldots \ldots \ldots \ldots \ldots$ 4-1

4.2 Unit Validation . . . . . . . . . . . . . . . . . . 4.3

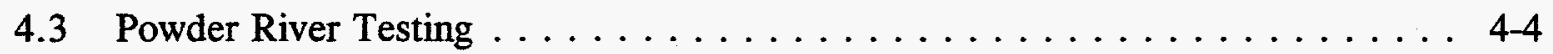

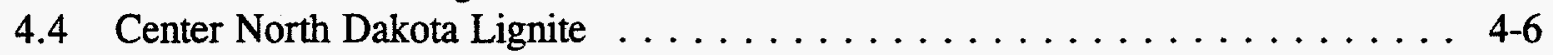

4.5 Mae Moh Thailand Lignite $\ldots \ldots \ldots \ldots \ldots \ldots \ldots \ldots \ldots$. . . . . . . . . .

4.6 Delayed Coke . . . . . . . . . . . . . . . . . . . 4-10

4.7 Fluid Coke . . . . . . . . . . . . . . . . . . . . 4-13

4.8 Dried Municipal Sewage Sludge (DMSS) $\ldots \ldots \ldots \ldots \ldots \ldots \ldots \ldots$ 4-13

4.9 Summary $\ldots \ldots \ldots \ldots \ldots \ldots \ldots \ldots \ldots \ldots \ldots \ldots \ldots \ldots \ldots \ldots \ldots \ldots \ldots \ldots \ldots .17$

\section{LIST OF FIGURES}

4-1 Schematic of EERC 1-MWth CFBC pilot plant $\ldots \ldots \ldots \ldots \ldots \ldots \ldots \ldots$ 4-1

4-2 Size distribution of baghouse ash from the Nucla Power Station and the Pyropower and

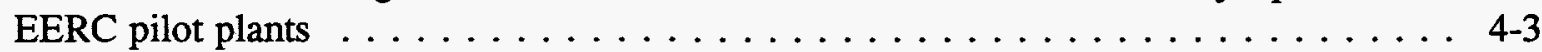

4-3 Probe deposits remaining in ash-fouling duct at the end of Powder River test . . . . . 4-4

4-4 Photomicrographs of outer portion of probe deposit from Powder River test . . . . . . 4-5

4-5 Photomicrograph of inner portion of probe deposit from Powder River test $\ldots \ldots$. 4-5

4-6 Convective pass ash-fouling probes after test with Thailand lignite $\ldots \ldots \ldots \ldots$ 4-8

4-7 Deposit formed on top of the shell-and-tube heat exchanger during the second week of testing using Thailand lignite $\ldots \ldots \ldots \ldots . \ldots . . . . .4$

4-8 SEM micrograph of the deposit from the shell-and-tube heat exchanger:

a) magnified 500 times, b) magnified 5000 times $\ldots \ldots \ldots \ldots \ldots \ldots$. . . . . . . .

4-9 Close-up of the agglomerates from EHX during delayed coke test $\ldots \ldots \ldots \ldots \ldots 4-11$

4-10 Ash coating on downstream side probe formed during delayed coke test . . . . . . 4-11

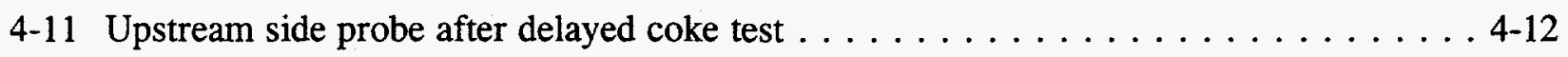

4-12 Deposits formed on the regenerator distributor plate when firing fluid coke with stoichiometric air 


\section{LIST OF FIGURES (continued)}

4-13 Deposits formed on the ash-fouling probes during the DMSS test . . . . . . . . 4-14

4-14 East ash-fouling probe temperatures during the second day of DMSS testing. . . . . . . . . . . . . . . . 4-15

4-15 East ash-fouling probe temperatures during the fourth day of DMSS testing . . . 4-16

\section{LIST OF TABLES}

4-1 Fuel Analyses $\ldots \ldots \ldots \ldots \ldots \ldots \ldots \ldots \ldots \ldots \ldots \ldots \ldots \ldots \ldots \ldots$

4-2 Results of SEM Analyses Performed on the Ash-Fouling Probe Deposits from the Powder River Test Run . . . . . . . . . . . . . . . . . . . . 4-6

4-3 Analysis of Deposit from the Shell-and-Tube Heat Exchanger . . . . . . . . . 4-10

4-4 Elemental Analysis of Ash and Deposits from DMSS Firing . . . . . . . . 4-16

4-5 Occurrence of Agglomeration When Firing Various Fuels in the EERC CFBC . . 4-18

4-6 Occurrence of Deposition When Firing Various Fuels in the EERC CFBC . . . . 4-19 


\subsection{PILOT-SCALE TESTING AT THE EERC}

The EERC has tested ten different fuels in its CFBC pilot plant. The purpose of these tests was primarily to gather operational, environmental, and thermal performance data that could be used for design and permitting of full-scale facilities. As a part of these tests, the tendency for each of the fuels tested to cause ash-related problems was evaluated. The results are presented because they were used to help elucidate mechanisms for deposition and agglomeration. In this section, the EERC CFBC and the properties of the fuels tested are described. Results from tests with those fuels that showed some tendency to form deposits or agglomerates are also presented.

\subsection{Equipment Used and Test Conditions}

A schematic of the EERC pilot-scale CFBC used in these studies is shown in Figure 4-1. The combustor has an internal diameter of $20 \mathrm{in}$. and is $42 \mathrm{ft}$ tall. The combustor is refractorylined, with twelve heat exchange panels located throughout seven of the combustor sections to control and adjust heat removal to match the heat duty of any fuel and/or operating conditions. The typical full-load thermal input of the unit is approximately $1 \mathrm{MWth}$. A 25-in. refractorylined cyclone is used to collect and recirculate the solids through a combination loop seal and external heat exchanger. Solids flow through the external heat exchanger at all times, but water flow to the cooling coils can be shut off to effectively take the heat removal function of the external heat exchanger off-line.

Fuel and sorbent are metered separately through rotary valves, mixed, and fed by gravity into the combustor. Combustion air is preheated to approximately $600^{\circ} \mathrm{F}$ and split between

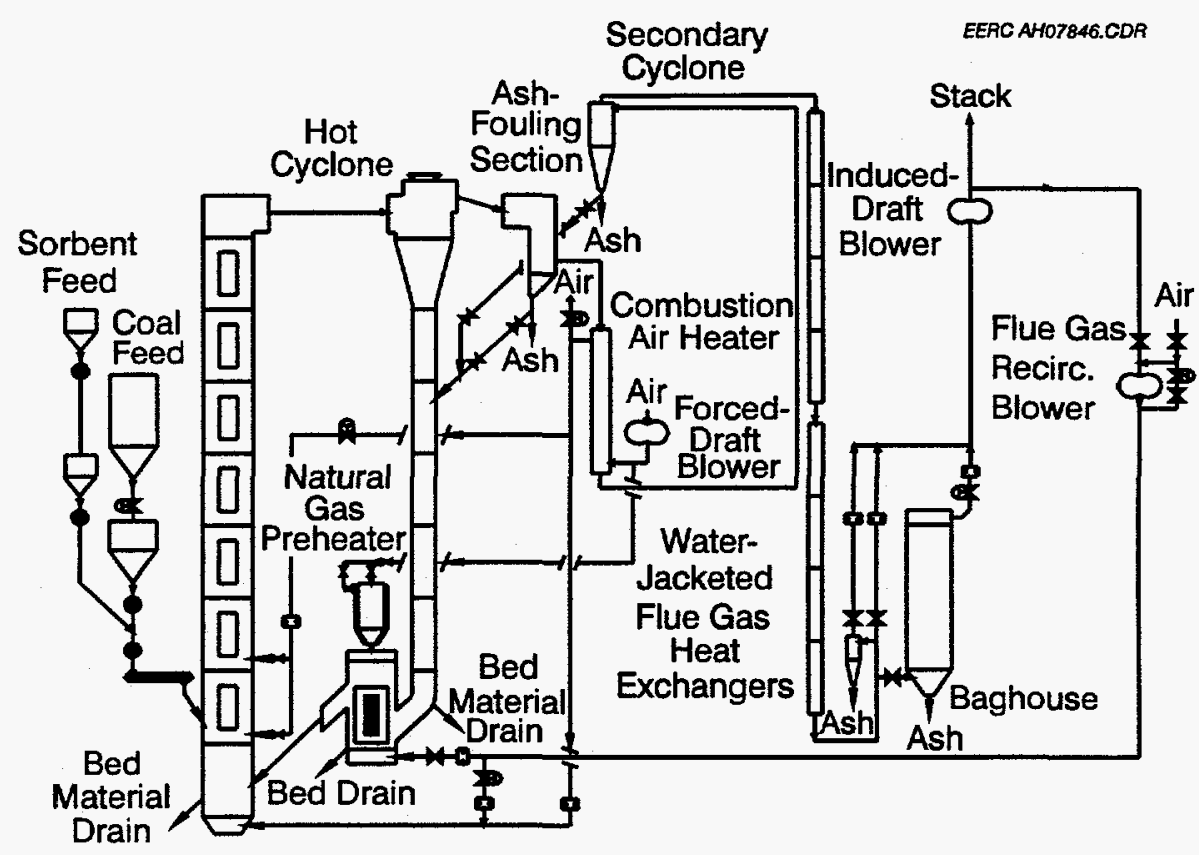

Figure 4-1. Schematic of EERC 1-MWth CFBC pilot plant. 
primary and secondary air. Secondary air can be fed into the combustor at 6 or $11 \mathrm{ft}$ above the distributor plate. Flue gas leaving the combustor passes across a convective fouling section that simulates the leading edge of a convective pass. The surface temperature of these tubes is maintained at $1000^{\circ} \mathrm{F}$. Solids collected in an 18-in. stainless steel secondary cyclone can either be returned to the combustor or collected to a barrel. The flue gas is then cooled by a series of water-cooled heat exchangers before entering a pulse-jet baghouse.

The data that follow summarize 70 steady-state tests performed over the following range of conditions:

$\begin{array}{ll}\text { Combustor Temperature, }{ }^{\circ} \mathrm{F} & 1185-1698 \\ \text { Excess Air, \% } & 9-125 \\ \text { Velocity, ft/sec } & 9-19 \\ \text { Ca:S, molar ratio } & 0-5.6 \\ \text { Primary Air, \% total air } & 40-92 \\ \text { Load, \% } & 50-100\end{array}$

Properties of the fuels used are presented in Table 4-1. A more detailed description of the facilities can be found elsewhere (EPRI, 1992).

TABLE 4-1

Fuel Analyses

\begin{tabular}{|c|c|c|c|c|c|c|c|c|c|c|}
\hline & $\begin{array}{c}\text { Delayed } \\
\text { Coke }\end{array}$ & $\begin{array}{l}\text { Fluid } \\
\text { Coke }\end{array}$ & Blacksville & $\begin{array}{c}\text { New } \\
\text { Mexico }\end{array}$ & $\begin{array}{c}\text { Salt } \\
\text { Creek }\end{array}$ & $\begin{array}{l}\text { Black } \\
\text { Thunder }\end{array}$ & $\begin{array}{l}\text { Powder } \\
\text { River }\end{array}$ & $\begin{array}{l}\text { Center } \\
\text { Lignite }\end{array}$ & $\begin{array}{l}\text { Sewage } \\
\text { Sludge }\end{array}$ & $\begin{array}{l}\text { Mae } \\
\text { Moh }\end{array}$ \\
\hline \multicolumn{11}{|c|}{ Proximate Analysis, as-received, wt \% } \\
\hline Moisture & 2.0 & 0.8 & 2.9 & 2.1 & 7.7 & 27.6 & 29.9 & 37.1 & 4.0 & 17.0 \\
\hline Volatile Matter & 13.9 & 4.6 & 35.1 & 33.0 & 31.0 & 33.2 & 32.6 & 29.0 & 53.1 & 37.4 \\
\hline Fixed Carbon & 80.5 & 94.1 & 53.8 & 52.4 & 42.7 & 34.6 & 33.0 & 28.9 & 4.6 & 7.6 \\
\hline Ash & 3.5 & 0.6 & 8.2 & 12.4 & 18.6 & 4.6 & 4.5 & 5.1 & 38.4 & 38.0 \\
\hline \multicolumn{11}{|c|}{ Ultimate Analysis, as-received, wt $\%$} \\
\hline Carbon & 82.4 & 91.5 & 74.4 & 73.7 & 58.8 & 49.9 & 48.8 & 40.9 & 31.6 & 25.0 \\
\hline Hydrogen & 3.5 & 1.9 & 5.3 & 4.9 & 5.0 & 6.6 & 6.7 & 7.0 & 4.4 & 4.3 \\
\hline Nitrogen & 1.4 & 1.6 & 1.3 & 1.4 & 1.1 & 0.6 & 0.7 & 0.5 & 3.9 & 0.7 \\
\hline Sulfur & 6.5 & 3.4 & 2.4 & 0.5 & 0.4 & 0.3 & 0.4 & 0.7 & 3.5 & 6.1 \\
\hline Oxygen & 2.0 & 0.9 & 8.4 & 7.0 & 16.0 & 38.0 & 39.0 & 45.8 & 19.3 & 26.1 \\
\hline Ash & 3.5 & 0.6 & 8.2 & 12.4 & 18.6 & 4.6 & 4.5 & 5.1 & 38.4 & 38.0 \\
\hline \multicolumn{11}{|c|}{ Ash Composition, as oxides, wt\% } \\
\hline Calcium, $\mathrm{CaO}$ & 2.2 & 5.0 & 5.6 & 8.5 & 1.5 & 24.4 & 24.1 & 22.6 & 12.5 & 19.9 \\
\hline Magnesium, $\mathrm{MgO}$ & 1.3 & 0.4 & 1.2 & 2.0 & 1.5 & 7.9 & 7.0 & 10.2 & 2.5 & 3.3 \\
\hline Sodium, $\mathrm{Na}_{2} \mathrm{O}$ & 0.2 & 0.3 & 0.7 & 0.8 & 0.2 & 0.5 & 1.2 & 3.7 & 1.0 & 0.3 \\
\hline Silica, $\mathrm{SiO}_{2}$ & 42.2 & 15.8 & 43.6 & 48.6 & 59.9 & 28.5 & 31.5 & 14.5 & 24.4 & 30.6 \\
\hline Aluminum, $\mathrm{Al}_{2} \mathrm{O}_{3}$ & 24.0 & 8.0 & 22.7 & 24.7 & 30.9 & 16.4 & 14.9 & 9.7 & 8.7 & 12.4 \\
\hline Ferric, $\mathrm{Fe}_{2} \mathrm{O}_{3}$ & 16.6 & 4.8 & 16.6 & 6.4 & 3.0 & 6.4 & 5.4 & 16.1 & 20.7 & 13.7 \\
\hline Titanium, $\mathrm{TiO}_{2}$ & 3.1 & 0.1 & 0.7 & 0.9 & 1.1 & 1.4 & 1.2 & 0.3 & 0.4 & 0.2 \\
\hline Phosphorus, $\mathrm{P}_{2} \mathrm{O}_{5}$ & 0.0 & 0.2 & 0.4 & 1.6 & 0.4 & 1.3 & 1.2 & 0.7 & 21.5 & 0.5 \\
\hline Potassium, $\mathrm{K}_{2} \mathrm{O}$ & 1.8 & 0.3 & 1.7 & 0.5 & 1.0 & 0.9 & 0.3 & 0.4 & 0.5 & 1.1 \\
\hline Sulfur, $\mathrm{SO}_{3}$ & 1.9 & 14.1 & 6.8 & 5.8 & 1.0 & 12.4 & 13.1 & 21.9 & 7.7 & 18.1 \\
\hline $\begin{array}{l}\text { High Heating Value, as- } \\
\text { received, Btu/lb }\end{array}$ & 14,607 & 14,345 & 13,274 & 12,965 & 10,274 & 8650 & 8472 & 6939 & 6289 & 3898 \\
\hline
\end{tabular}




\subsection{Unit Validation}

The 110-MWe CFBC at the Colorado Ute Nucla Station has been successfully operating for the last several years. As it is one of the demonstration plants supported by the Electric Power Research Institute (EPRI), EPRI was able to assemble a large database characterizing the performance of this unit. In addition, EPRI and Pyropower participated in pilot plant testing in a pilot-scale CFBC in San Diego, California. The EERC obtained samples of the same coal and limestone used by those organizations and has operated its CFBC under similar operating conditions. This has provided the opportunity to compare the performance of the EERC CFBC with both a utility-scale plant and a vendor-operated pilot plant.

To simulate full-scale operation, the size distribution of the recirculating material and the fly ash from the pilot plant must be similar to that of a full-scale system. Figure 4-2 shows that the fly ash generated from the three units is similar. Chemical compositions of the ash material were also compared and are similar. Operation of the system at typical full-scale conditions provides scalable heat flux and emissions data. Average heat flux in the combustor ranged from $18,200 \mathrm{Btu} / \mathrm{hr}-\mathrm{ft}^{2}$ at $55 \%$ load to $26,000 \mathrm{Btu} / \mathrm{hr}-\mathrm{ft}^{2}$ at $88 \%$ load and $32,600 \mathrm{Btu} / \mathrm{hr}-\mathrm{ft}^{2}$ at full load. The measured heat flux from the Nucla Station averaged $22,300 \mathrm{Btu} / \mathrm{hr}-\mathrm{ft}^{2}$ at half load and $32,800 \mathrm{Btu} / \mathrm{hr}-\mathrm{ft}^{2}$ at full load. Bed temperature distribution in the combustor for all full-load tests was uniform over the entire length of the EERC combustor and was similar to that observed at the San Diego pilot plant. Emissions of $\mathrm{SO}_{2}, \mathrm{NO}_{\mathrm{x}}$, and $\mathrm{CO}$ among the three units were also similar.

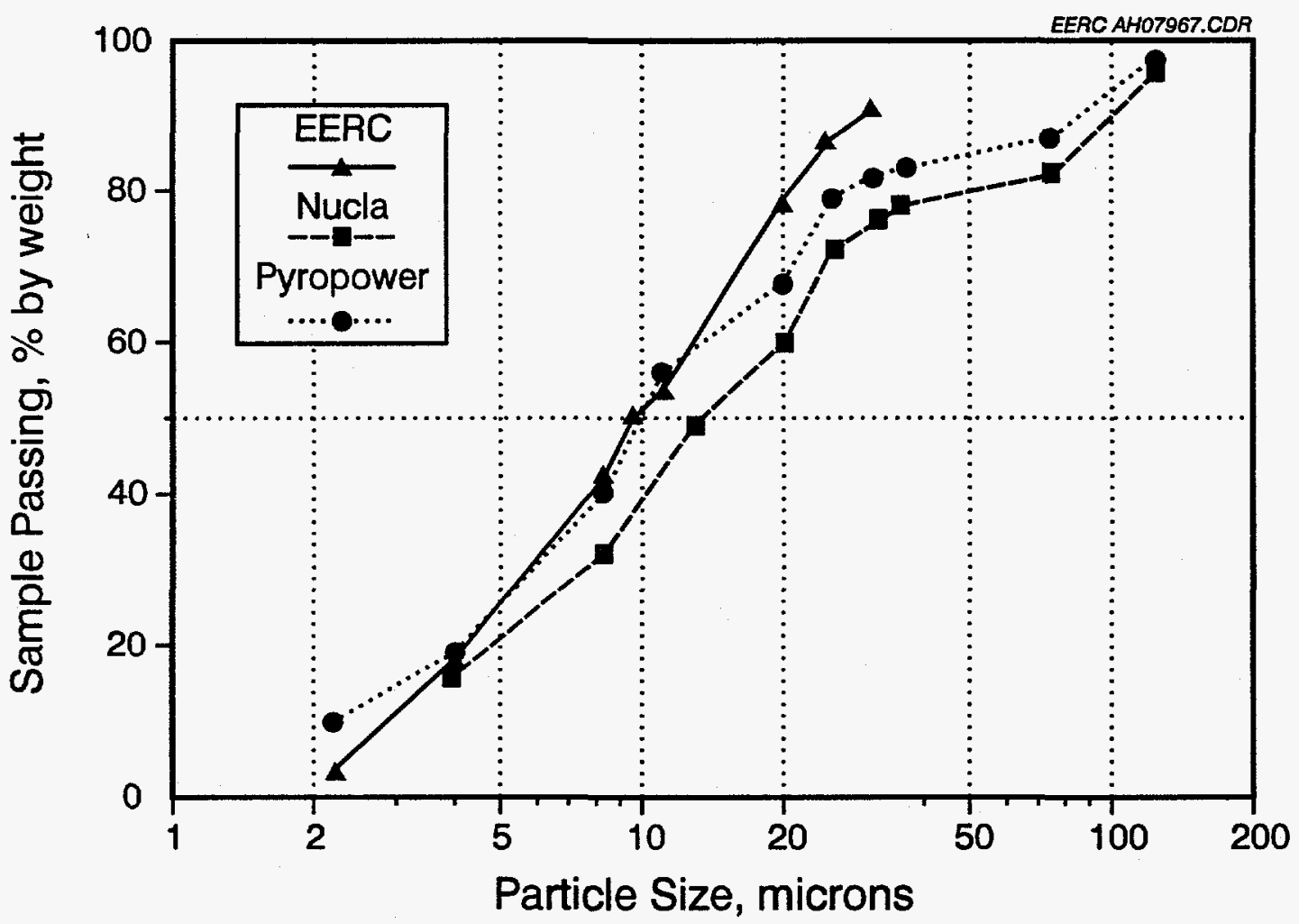

Figure 4-2. Size distribution of baghouse ash from the Nucla Power Station and the Pyropower and EERC pilot plants. 
Based on this comparison, EERC personnel feel confident that the EERC 1-MWth pilotscale CFBC can provide data scalable to full-scale units. Further details of the validation tests are presented in Henderson and others (1991) and Moe and others (1993).

\subsection{Powder River Testing}

A one week test was performed using the Powder River Basin (PRB) coal, there were some indications that the ash produced had the tendency to stick. During the first day of operation, it was difficult to maintain a steady flow of solids through the downcomer. At the end of the run there was 216 pounds of bed material hung up in the downcomer of the total 545 pounds of bed material removed from the system. The material was readily removed during maintenance and did not contain any agglomerates. The most significant indication was the formation of deposits on the downstream side of the ash-fouling probes. The deposits that had formed fell off the probes prior to the removal of the probe door. The average temperature in the ash fouling section ranged from $1370^{\circ}$ to $1460^{\circ} \mathrm{F}$. The probes were air-cooled to maintain them at approximately $1000^{\circ} \mathrm{F}$. Figure $4-3$ is a photograph of the deposits in the 12 -in.-wide ash-fouling section.

These deposits were examined using a scanning electron microscope to provide some information on their physical and chemical composition and to provide insight on their method of formation. Figures 4-4 and 4-5 are photomicrographs from the outer part of the deposit and the inner part near the probe, respectively. Point analyses, indicated by the numbered points on Figures 4-4 and 4-5, were performed for some representative locations to look at elemental

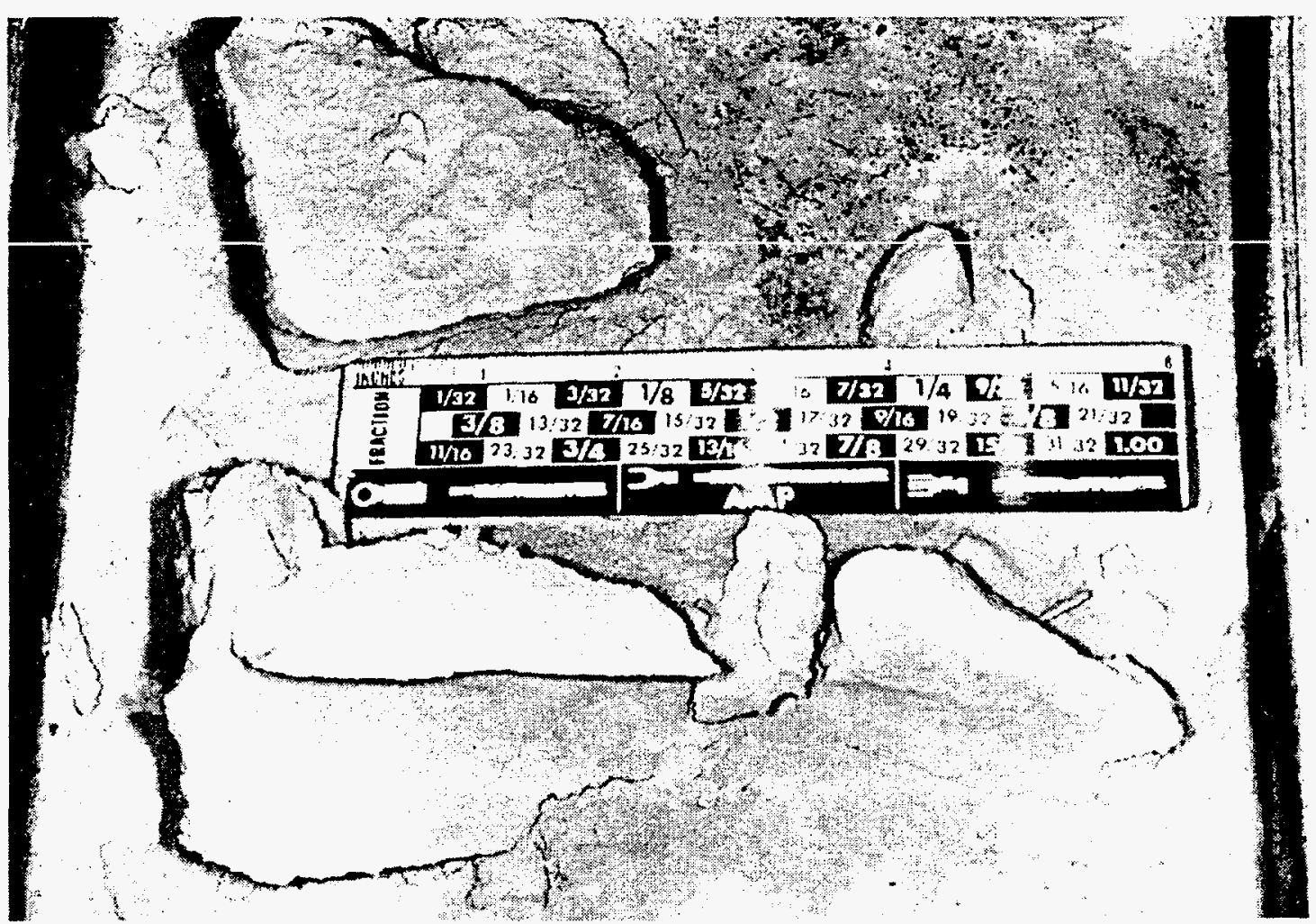

Figure 4-3. Probe deposits remaining in ash-fouling duct at the end of Powder River test. 


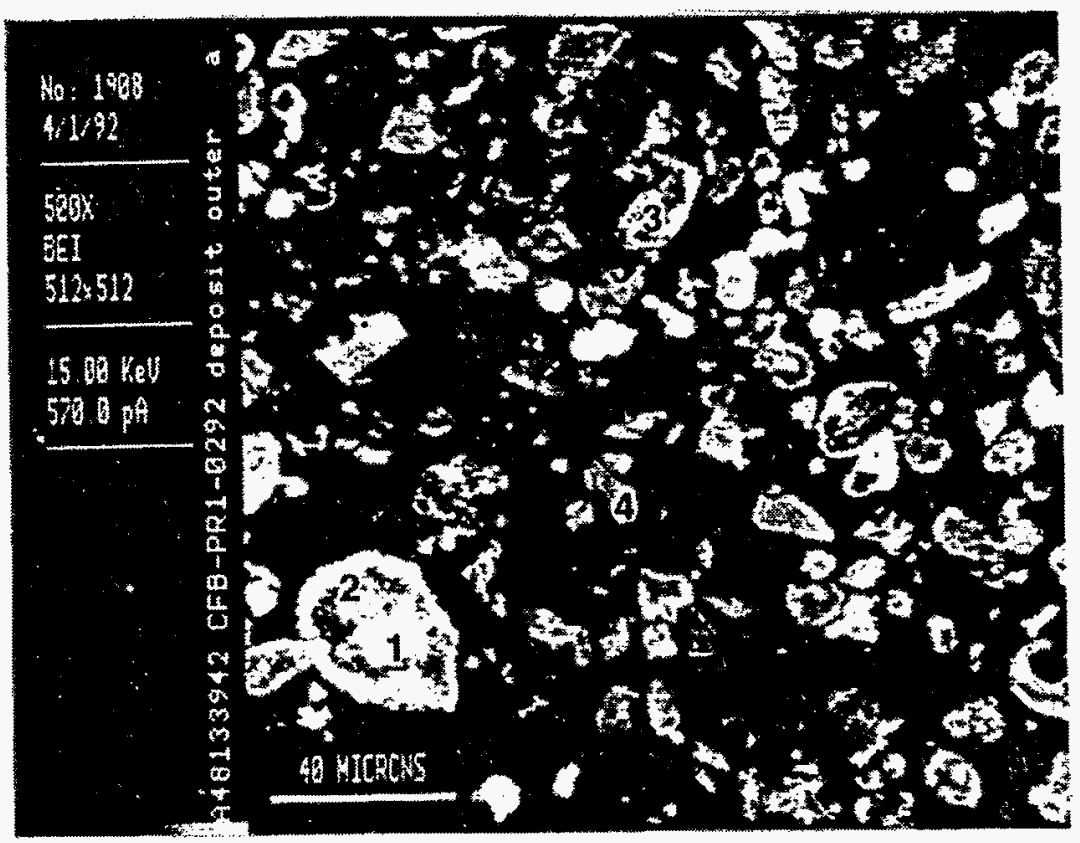

Figure 4-4. Photomicrographs of outer portion of probe deposit from Powder River test.

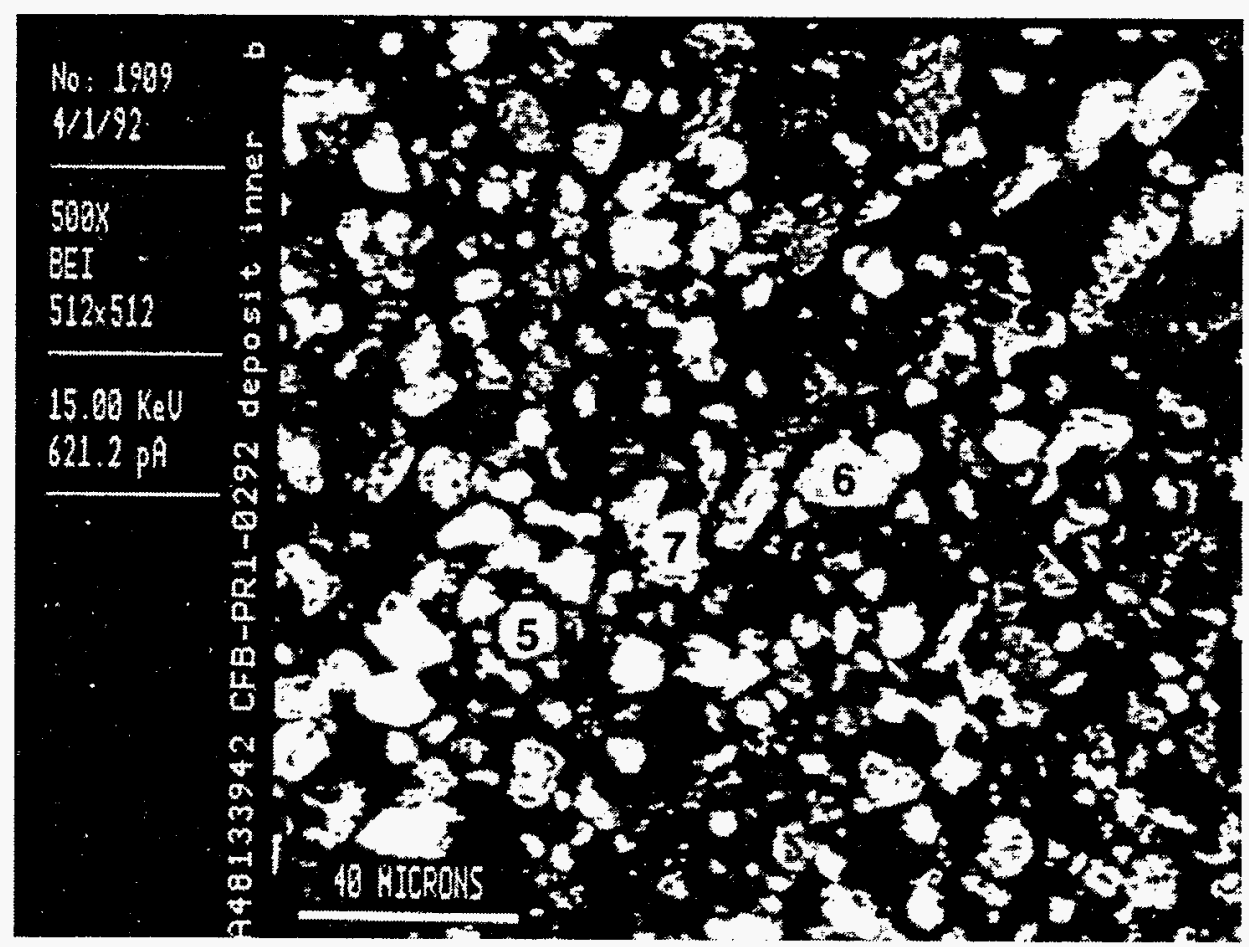

Figure 4-5. Photomicrograph of inner portion of probe deposit from Powder River test. 
compositions. The compositions of the selected particles are listed in Table 4-2. The inner portion consists mostly of partially sulfated limestone particles, while the outer portion is made up of more fully sulfated limestone particles. Analyses indicated that the particles on the outside were slightly larger, with a mean diameter of $6.6 \mu \mathrm{m} \pm 4.9 \mu \mathrm{m}$ compared to a mean diameter of $5.2 \mu \mathrm{m} \pm 4.8 \mu \mathrm{m}$ for particles near the tube surface.

\subsection{Center North Dakota Lignite}

Two week-long tests were performed with Center lignite. After the first week of testing, some small agglomerates of about $1 / 8$-in. diameter were noted in the combustor bed material, but did not pose any operational problems. Postrun visual inspection of the system after the second week of testing showed the formation of high-temperature agglomeration in the bottom of the combustor. This was likely an artifact of the plugging in the downcomer and a consequence of the temperature excursion. Bed material agglomerates slightly larger than 1 and $1 / 2$ in. thick were found in the drained bed material. These were quite friable. The material that collected and plugged the cyclone and downcomer appeared to be extremely cohesive and was relatively easy to clean out of the cyclone cone and downcomer. The material forming the plug could be broken with finger pressure, and was composed of partially sulfated calcium oxide. Some slightly larger and harder agglomerates, along with some ash deposits, were found in the material removed from the downcomer and external heat exchanger.

Two air-cooled probes located at the exit of the cyclone are used to investigate the degree of ash deposition or slagging that could be expected at the leading edge of the convective pass

\section{TABLE 4-2}

Results of SEM Analyses Performed on the Ash-Fouling Probe Deposits from the Powder River Test Run

\begin{tabular}{|c|c|c|c|c|c|c|c|c|}
\hline & $\%$ & Normalized, \% & $\%$ & Normalized, $\%$ & $\%$ & Normalized, $\%$ & $\%$ & Normalized, $\%$ \\
\hline & \multicolumn{8}{|c|}{ Outer Portion } \\
\hline Particle No. & \multicolumn{2}{|r|}{1} & \multicolumn{2}{|r|}{2} & \multicolumn{2}{|r|}{3} & \multicolumn{2}{|r|}{4.} \\
\hline $\mathrm{MgO}$ & 0.70 & 0.715 & 2.15 & 2.326 & 1.05 & 1.167 & 0.00 & 0.000 \\
\hline $\mathrm{Al}_{2} \mathrm{O}_{3}$ & 0.00 & 0.000 & 2.29 & 2.477 & 0.00 & 0.000 & 0.22 & 0.274 \\
\hline $\mathrm{SiO}_{2}$ & 0.22 & 0.225 & 0.68 & 0.736 & 0.00 & 0.000 & 79.48 & 98.880 \\
\hline $\mathrm{SO}_{3}$ & 29.88 & 30.530 & 44.64 & 48.291 & 51.75 & 57.494 & 0.00 & 0.000 \\
\hline $\mathrm{CaO}$ & 66.01 & 67.447 & 39.85 & 43.109 & 36.77 & 40.851 & 0.38 & 0.473 \\
\hline $\mathrm{Fe}_{2} \mathrm{O}_{3}$ & 0.00 & 0.000 & 1.98 & 2.142 & 0.00 & 0.000 & 0.30 & 0.373 \\
\hline \multirow[t]{2}{*}{ Total } & 97.87 & & 92.44 & & 90.01 & & 80.38 & \\
\hline & \multicolumn{6}{|c|}{ Inner Portion } & & \\
\hline Particle No. & \multicolumn{2}{|r|}{5} & \multicolumn{2}{|r|}{6} & \multicolumn{2}{|r|}{7} & & \\
\hline $\mathrm{MgO}$ & 1.23 & 1.242 & 0.37 & 0.571 & 0.00 & 0.000 & & \\
\hline $\mathrm{Al}_{2} \mathrm{O}_{3}$ & 2.27 & 2.292 & 0.21 & 0.324 & 0.00 & 0.000 & & \\
\hline $\mathrm{SiO}_{2}$ & 3.92 & 3.958 & 0.00 & 0.000 & 0.22 & 0.377 & & \\
\hline $\mathrm{SO}_{3}$ & 44.36 & 44.790 & 9.78 & 15.086 & 6.35 & 10.875 & & \\
\hline $\mathrm{CaO}$ & 44.79 & 45.224 & 53.80 & 82.986 & 51.36 & 87.960 & & \\
\hline $\mathrm{Fe}_{2} \mathrm{O}_{3}$ & 2.22 & 2.242 & 0.00 & 0.000 & 0.00 & 0.000 & & \\
\hline Total & 99.04 & & 64.83 & & 58.39 & & & \\
\hline
\end{tabular}


region of a circulating fluidized-bed boiler. Air flow to the probes was controlled to maintain a probe surface temperature of approximately $1000^{\circ} \mathrm{F}$. Only a thin layer of deposit less than $1 \mathrm{~mm}$ thick was present on the probes after the second week of testing. This contrasts to a much thicker deposit that formed during the first week of testing using Center lignite when the probes installed in the ash-fouling section were uncooled.

Postrun inspection of system components revealed several hard deposits had formed on the walls of the refractory and on some of the uncooled surfaces. The deposits were not very thick and were composed of a very fine-grained matrix, with most of the particles less than 1 micron. A few larger particles (1-10 microns) were found intermixed in the fine-grained matrix. The elemental analyses show that the deposit is primarily composed of calcium and sulfur. XRD identified the major phases as $\mathrm{CaSO}_{4}$ and $\mathrm{Ca}_{5}\left(\mathrm{PO}_{4}\right)_{3} \mathrm{OH}$, with minor amounts of $\mathrm{MgO}$ and $\mathrm{Ca}_{3} \mathrm{Al}_{6} \mathrm{O}_{12} \mathrm{CaSO}_{4}$. This composition differs from both the coal and the limestone analyses, showing an enrichment in the calcium and sulfur. The most likely mechanism for the formation of this deposit is deposition of fine-grained calcium oxide. Sulfation of the calcium oxide and subsequent sintering of the particles produce a very hard, tenacious deposit. Some of the ash particles appear to have stuck to the deposit; however, it is unlikely that any of the constituents in these ash particles caused the deposit to form or gave it strength.

\subsection{Mae Moh Thailand Lignite}

No evidence of bed material agglomeration or ash deposition in the combustor, downcomer, or external heat exchanger was noted during either of the two weeks of testing. Based on the low sodium and potassium content in the Mae Moh lignite received and tested in the EERC CFBC pilot plant, it was expected that agglomeration would not be a concern. The high bed drain rate that results from the high limestone bed rate required to maintain $90 \%$ sulfur capture serves as a constant purge of the alkali material.

There were several upsets in operational conditions during the two weeks of testing that are more favorable for the formation of agglomerates, based on past experience at the EERC. At the end of the first week of testing, because of the leak in the air heater, conditions in the combustor were highly reducing, and, immediately before shutdown, there was a temperature excursion up to approximately $1720^{\circ} \mathrm{F}$. There were three separate occasions that forced a hot slump of the bed during the first week of testing. The last two hot slumps occurred without sufficient time available for the carbon present in the bed to completely burn out.

During the second week of testing, there was one intentional hot bed slump to retain heat in the combustor until a coal plug could be remedied. Several bed slumps were required during a short period of time on the final day of testing to restart the induced-draft blower. Despite all of these considerable process interruptions, as well as operation of the combustor at greatly reduced bed drain rates during the final 24 hours of Week 2, agglomeration was not a problem and is not expected to be a problem when firing this fuel in a full-scale unit.

A significant quantity of large bed material particles accumulated within the combustor during testing. It is likely that this was an accumulation of clay or rock that was fed into the combustor along with the coal. 
A thin layer of ash, less than $1 \mathrm{~mm}$ thick, was present on the ash-fouling probes at the conclusion of the run. A photograph of the probes removed from the ash-fouling section immediately after the run is presented as Figure 4-6. Ash deposition would not likely be a problem in the convective pass region of a CFB boiler firing this coal.

Postrun inspection of system components revealed a deposit which had formed on top of the shell-and-tube air-to-flue gas heat exchanger located at the exit of the ash-fouling section. Figure 4-7 shows the deposit that was removed during maintenance after the second week of testing. The deposit is a very fine-grained matrix, with most of the particles less than 1 micron. A few larger particles (1-10 microns) were found intermixed in the fine-grained matrix. The flue gas temperature entering the heat exchanger is approximately $1400^{\circ} \mathrm{F}$.

Figures 4-8a and 4-8b are SEM photographs showing the morphology of the deposit from the shell-and-tube heat exchanger. The relatively smooth surface of the deposit can be seen in these high-magnification shots. The flow of the flue gas and possible erosion from larger ash particles produced a hill-and-valley-like terrain on the deposit. The photograph in Figure $4-8$ b shows that the matrix is very fine-grained, with some ash particles adhering to this matrix. An analysis of the deposit is given in Table 4-3. The elemental analyses show that the deposit is primarily composed of calcium and sulfur, with a relatively large amount of iron. This composition differs from both the coal and the limestone analyses, showing an enrichment in the calcium, iron, and sulfur. Further analysis of this deposit using scanning

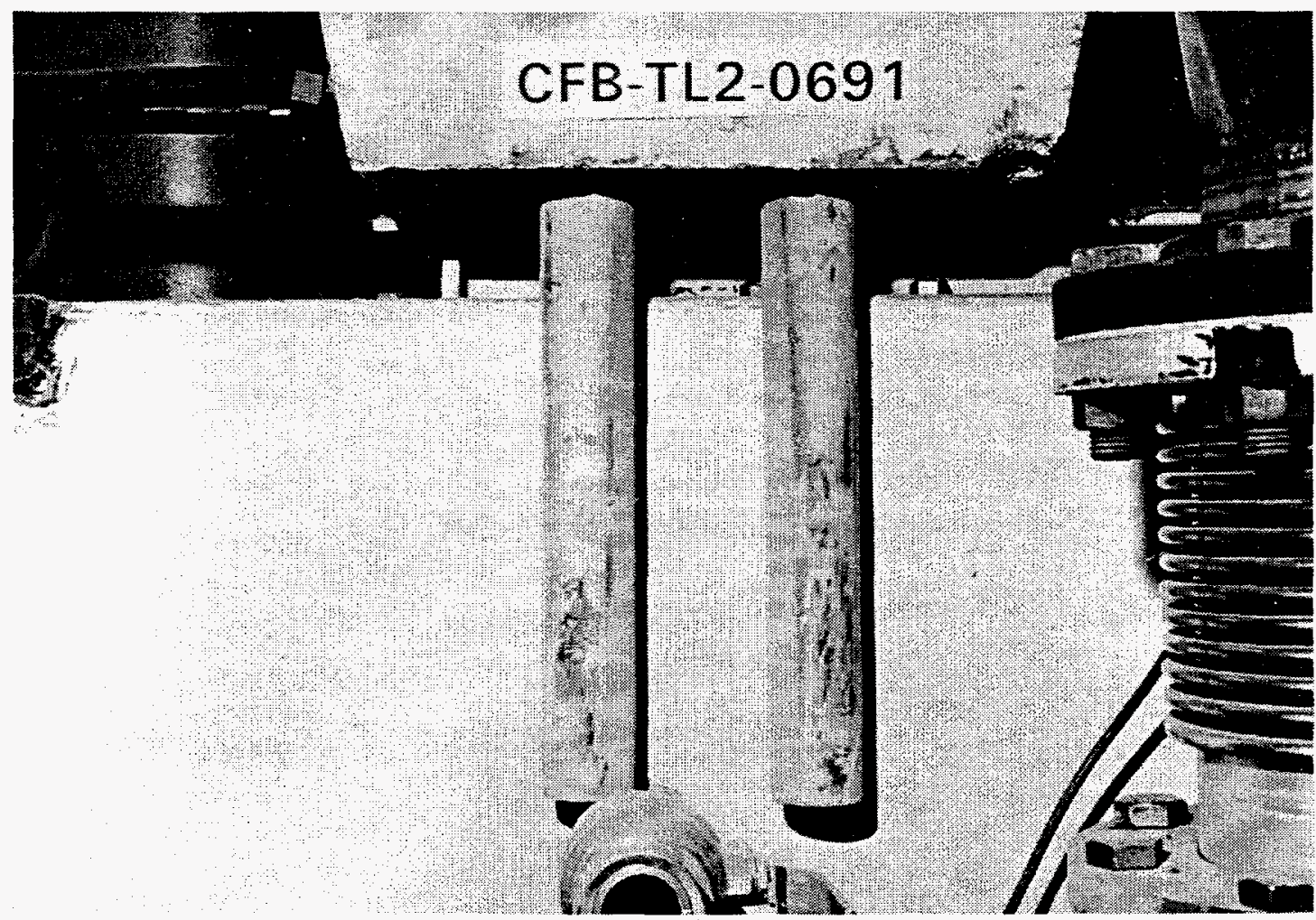

Figure 4-6. Convective pass ash fouling probes after test with Thailand lignite. 


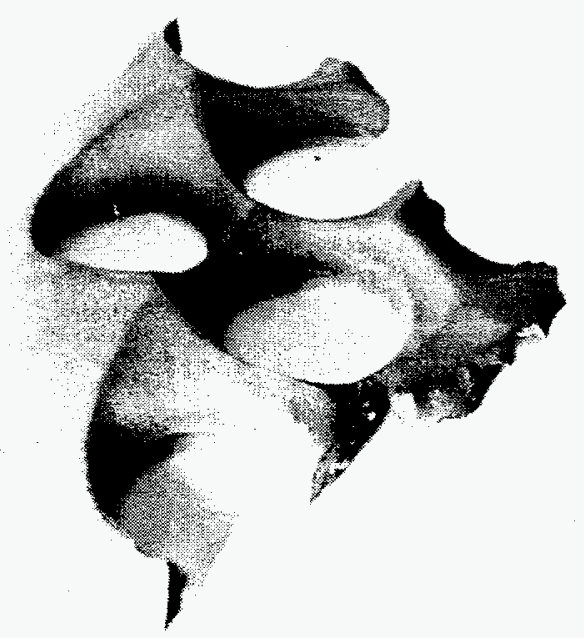

Figure 4-7. Deposit formed on top of the shell-and-tube heat exchanger during the second week of testing using Thailand lignite.
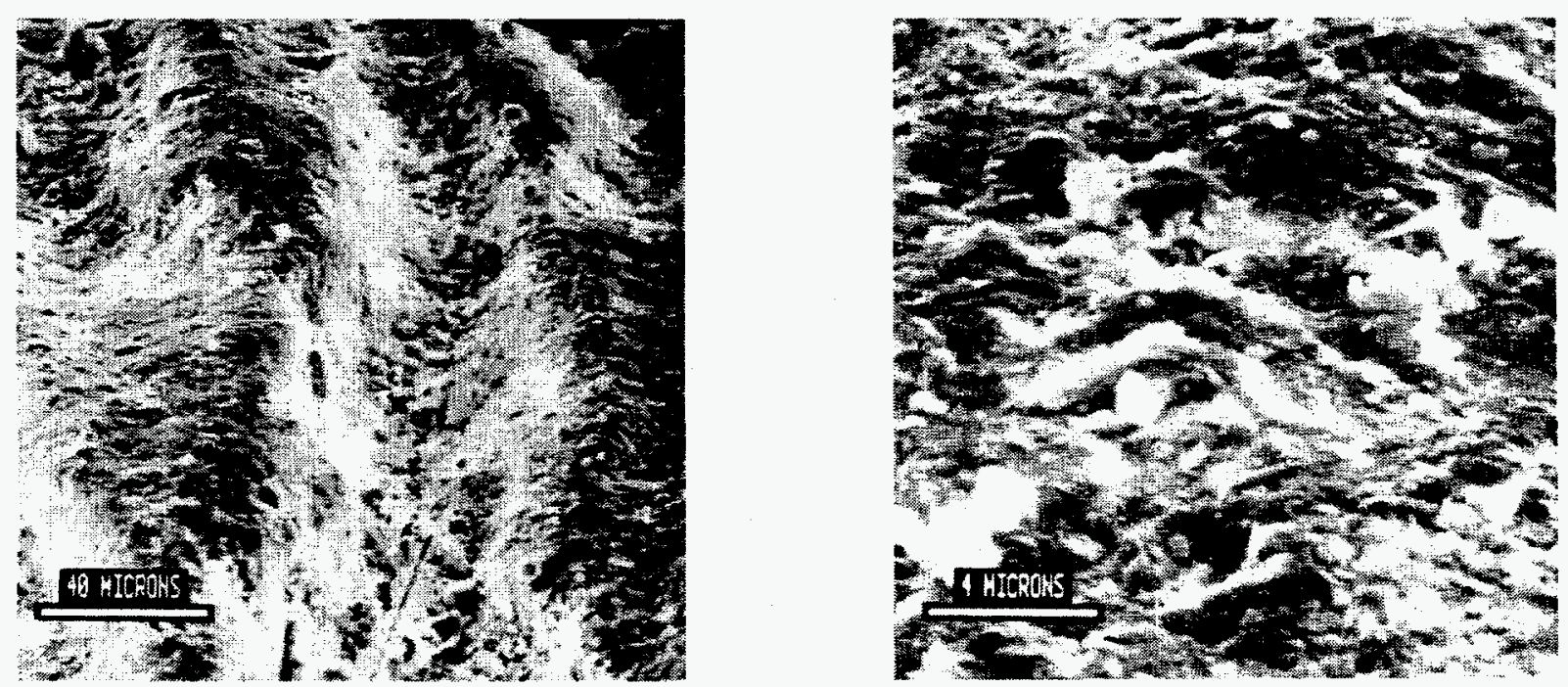

Figure 4-8. SEM micrograph of the deposit from the shell-and-tube heat exchanger: a) magnified 500 times, b) magnified 5000 times. 


\section{TABLE 4-3}

Analysis of Deposit from the Shell-and-Tube Heat Exchanger

\begin{tabular}{lc}
\hline Oxides & $w \%$ \\
$\mathrm{SiO}_{2}$ & 5.9 \\
$\mathrm{Al}_{2} \mathrm{O}_{3}$ & 3.3 \\
$\mathrm{Fe}_{2} \mathrm{O}_{3}$ & 15.1 \\
$\mathrm{TiO}_{2}$ & 0.0 \\
$\mathrm{P}_{2} \mathrm{O}_{5}$ & 0.9 \\
$\mathrm{CaO}$ & 35.6 \\
$\mathrm{MgO}$ & 4.7 \\
$\mathrm{Na}_{2} \mathrm{O}$ & 0.1 \\
$\mathrm{~K}_{2} \mathrm{O}$ & 0.3 \\
$\mathrm{SO}_{3}$ & 34.1 \\
$\mathrm{Minerals}$ & Identified by XRD \\
Anhydrite $\left(\mathrm{CaSO}_{4}\right)$ & Major Phase \\
Maghemite $\left(\mathrm{Fe}_{2} \mathrm{O}_{3}\right)$ & Minor Phase \\
Hematite $\left(\mathrm{Fe}_{2} \mathrm{O}_{3}\right)$ & Minor Phase \\
\hline
\end{tabular}

electron microscope point count identified calcium sulfate as the primary phase. Some of the ash particles appear to have stuck to the deposit, however, it is unlikely that any of the constituents in these ash particles caused the deposit to form or gave it strength. The iron inclusions are probably from fine-grained pyrite being preferentially carried out of the combustor and deposited with the calcium oxide.

\subsection{Delayed Coke}

A one-week test was performed using a delayed coke. Postrun inspection of the external heat exchanger (EHX) distributor plate revealed some bed agglomerates between the EHX fluidizing air nozzles. Figure 4-9 is a close-up of the agglomerates. The largest agglomerate in Figure 4-9 is $3.1 \mathrm{in}$. long by $1.4 \mathrm{in}$. high. Overall, the agglomerates ranged in size from about 3/4-in. blocks to 1-in.-square by 4 -in. long chunks, and they appeared to be loosely consolidated. Experience in other operating plants has shown that the high vanadium content in petroleum coke can cause agglomeration problems, particularly in the loop seal. The reducing conditions in the loop seal/EHX are thought to favor agglomeration. Avoidance of temperature excursions is also critical in reducing agglomeration potential.

A coating of ash less than or equal to $1 / 4$ in. was present on the downstream side of the ash-fouling probes at the end of the run, as shown in Figure 4-10. Figure 4-11 shows the relatively clean upstream side of the probes. The deposits were very soft and easy to remove. An additional 10-15 pounds of the same type of ash was found beneath the probes in the flue gas ducting. 


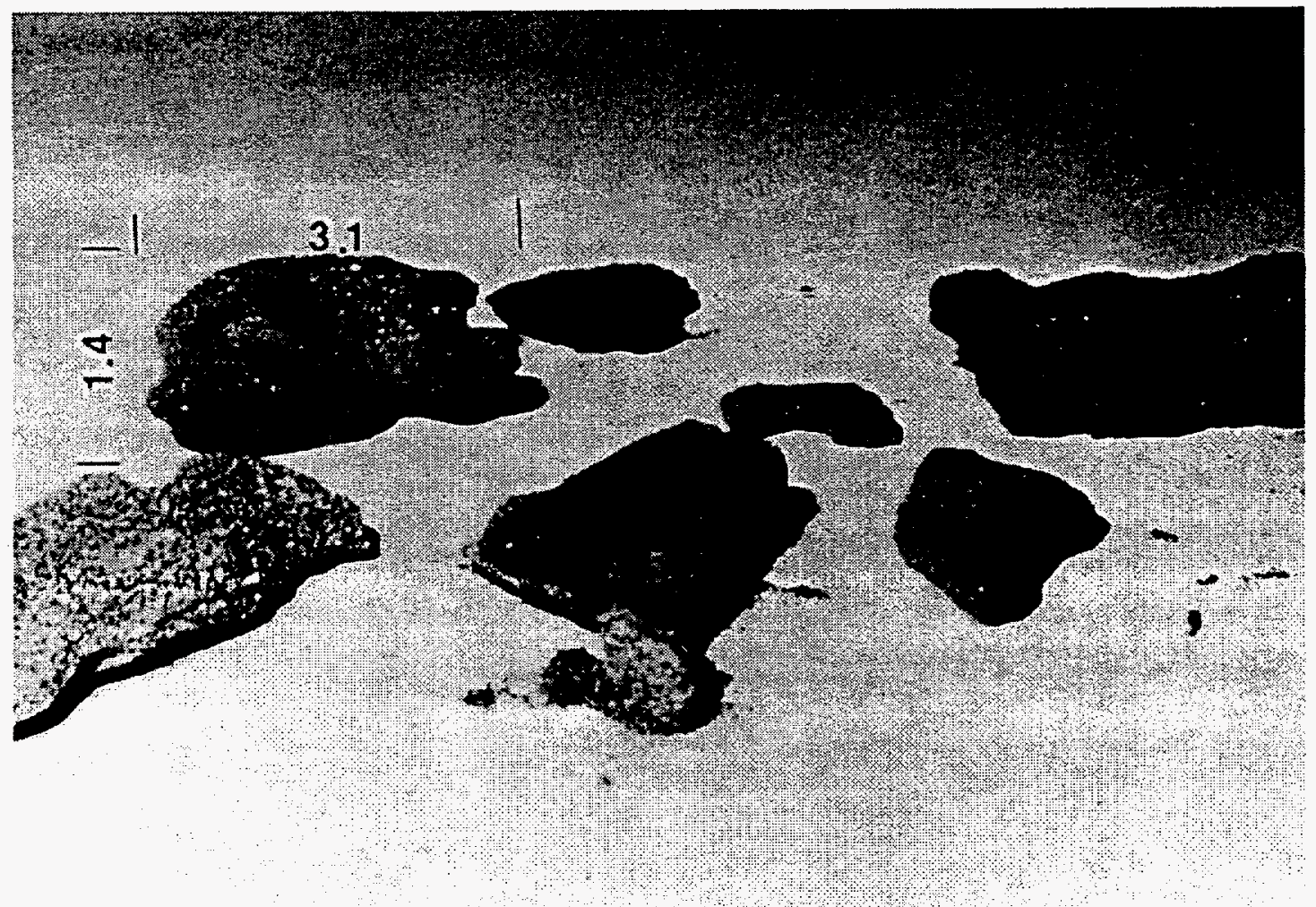

Figure 4-9. Close-up of the agglomerates from EHX during delayed coke test.

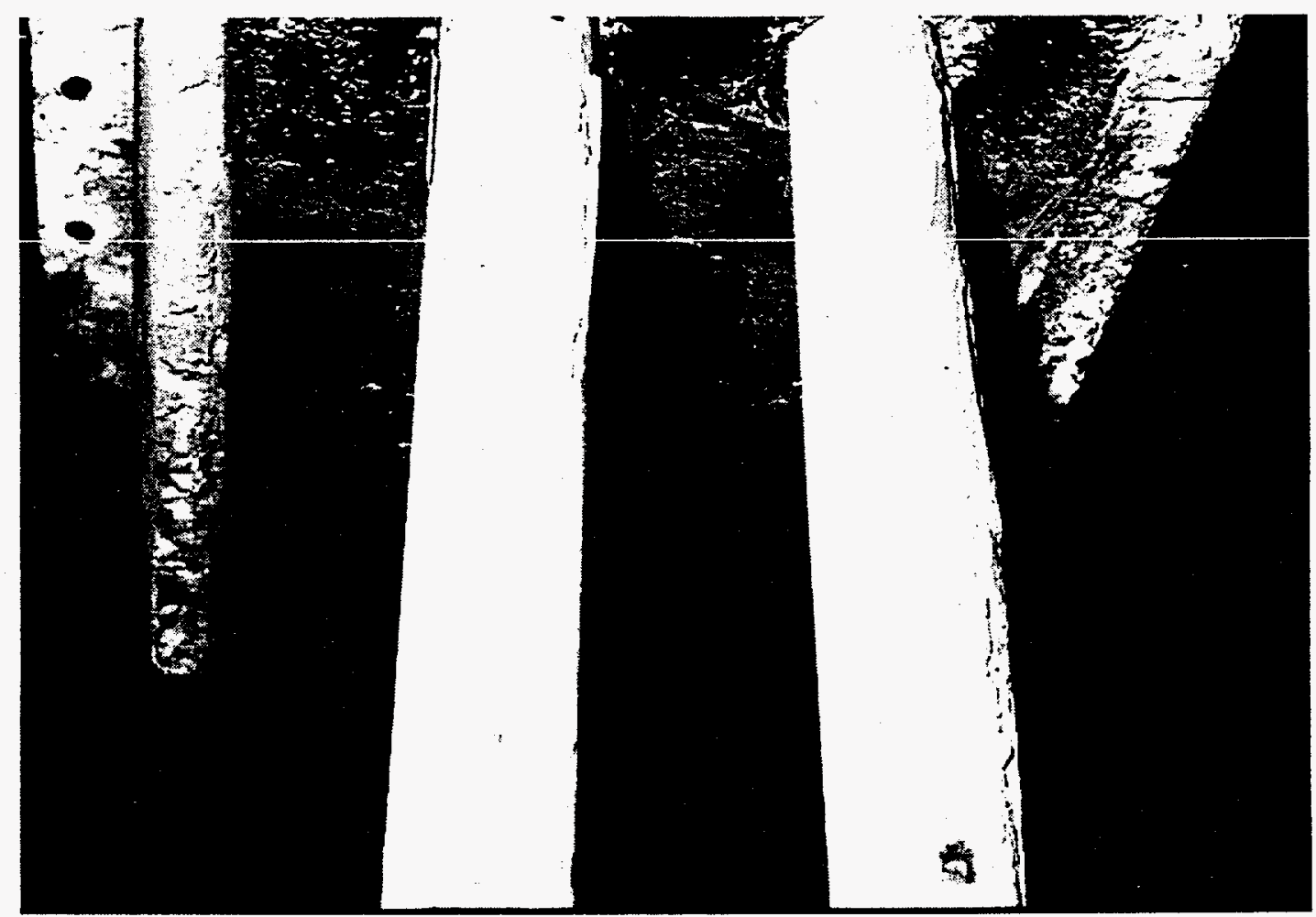

Figure 4-10. Ash coating on downstream side probe formed during delayed coke test. 


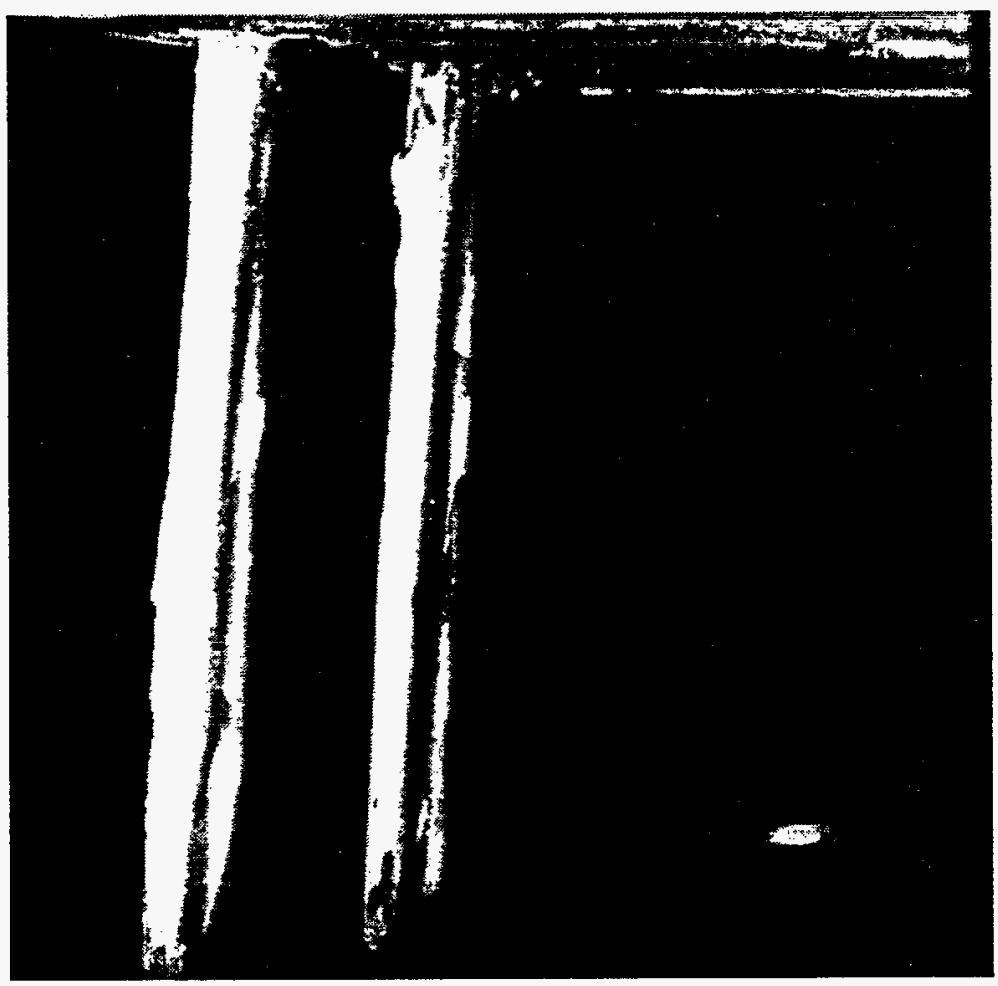

Figure 4-11. Upstream side probe after delayed coke test.

Two probe deposits and one agglomerate were analyzed using SEMPC to determine their composition and provide possible insights into the methods of formation. The agglomerate was composed of approximately $55 \%$ calcium sulfate and $35 \%$ silicon dioxide. Overall, $27 \%$ of the material in the agglomerate was quartz. Most of the quartz likely resulted from the use of silica sand for startup. Some of the silicon dioxide in the agglomerate was from the coke ash and limestone, but insignificant amounts of this would be in the form of quartz. The agglomerates were a collection of mostly limestone particles, with some silica sand particles. At the point of contact between particles, the material was calcium sulfate. Only extremely small traces of vanadium which is statistically associated with the presence of AlSiSCa systems could be detected. Essentially no nickel was detected in the sample. Inspection of the agglomerate with the SEM showed the vanadium was present only on the surface of quartz particles that were probably silica sand.

The probe deposits are composed of almost totally calcined and sulfated particles of less than $50 \mu \mathrm{m}$. There was again about $55 \%$ calcium sulfate, but only $29 \%$ silicon dioxide, with $8 \%$ of the total sample being quartz. Some of the other remaining elemental components were, on an average for the two deposits, $8.2 \% \mathrm{Al}_{2} \mathrm{O}_{3}, 1.0 \% \mathrm{Cl}_{2} \mathrm{O}_{7}, 3.2 \% \mathrm{FeO}, 0.6 \% \mathrm{~V}_{2} \mathrm{O}_{5}$, and $0.2 \% \mathrm{NiO}$. There is no evidence that the vanadium or nickel promotes the formation of these deposits. The vanadium again is more associated with either the ash particles or some residual silica sand in the system than with the sulfated limestone. The potential for convective pass fouling is expected to be low when a CFB boiler is operated with this type of fuel and limestone.

4-12 


\subsection{Fluid Coke}

CFBC testing of fluid coke indicated that there could be some potential for the occurrence of agglomeration. At the end of this test, a deposit was located at the bottom of the primary cyclone blocking about half of the 6-in.-diameter downcomer entrance. This deposit was relatively soft and readily broke up when removed. Several soft, layered deposits were found in the ash-fouling section of the EERC CFBC.

As part of this test series, the bed material was subjected to higher temperatures in a separate bubbling bed to drive off the sulfur from the sorbent to "regenerate" it. This was done at stoichiometric conditions using the fluid coke to provide the heat for regeneration. If the spent bed material was fed directly into a hot regenerator bed consisting of fresh limestone, no agglomeration occurred. However, if the material was put into a warm $\left(1500^{\circ} \mathrm{F}\right)$ fluid bed and petroleum coke fired with stoichiometric air, massive sintering and solid fixation of the bed occurred at a temperature of approximately $1725^{\circ} \mathrm{F}$ (see Figure 4-12). This indicates a phase change at this temperature. Usually, $\mathrm{CaS}$ is unstable in air and/or water vapor, and decomposes at temperatures above $1718^{\circ} \mathrm{F}$. The lowest melting temperature in the potassium sulfate-sulfide system appears at about $1112^{\circ} \mathrm{F}$.

\subsection{Dried Municipal Sewage Sludge (DMSS)}

Because of the high phosphorus and calcium levels in the test fuel, there were some concerns that minor ash-related problems might surface. During the test, larger ash particles were observed in the spent bed material. These particles had a rough surface and, upon visual

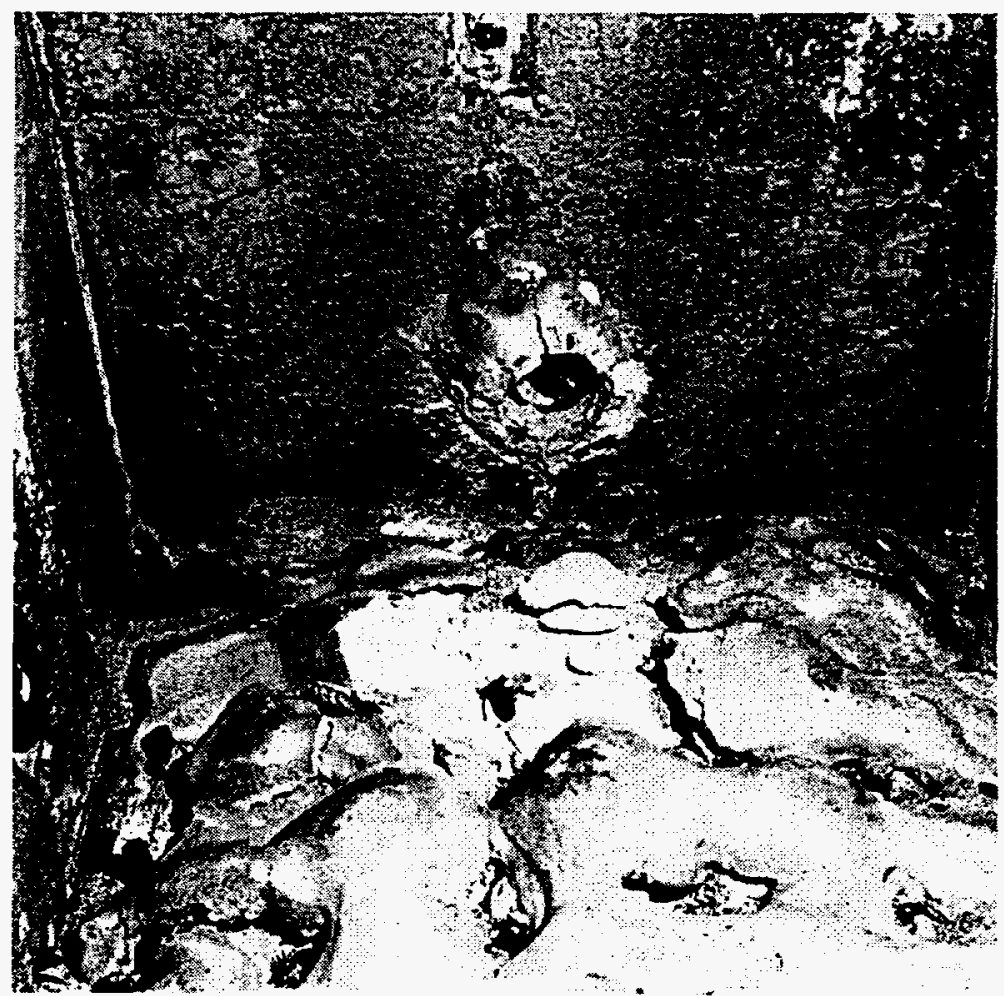

Figure 4-12. Deposits formed on the regenerator distributor plate when firing fluid coke with stoichiometric air. 
observation, appeared to consist of several smaller particles. This indicated the onset of agglomeration. However, when these bed particles were observed under the SEM, it was evident that they were the remains of large fuel particles. No evidence of agglomeration was seen in any of the bed particles under the SEM. Examination of the bed drain material as a function of run time also showed no evidence of agglomeration.

The tendency of this fuel to foul the convective pass of the EERC CFBC was measured by the ash-fouling probes located just after the primary cyclone. Figure 4-13 shows deposits that had formed during the week-long test. The thin deposits shown on the left formed on the front side of the tubes, while the thick deposit formed on the back side of the tubes. The thin deposit was very hard, while the thicker deposit was soft. The average gas temperature in the ash-fouling section ranged from $1350^{\circ}$ to $1650^{\circ} \mathrm{F}$, while the tube surface temperature ranged from $500^{\circ}$ to $1100^{\circ} \mathrm{F}$.

Figure 4-14 shows the ash-fouling probe temperatures for the second day of the run. During the course of the day, each probe showed significant drops in temperature, indicating that deposits were growing on the front tube surface, then apparently dropping off, evidenced by high temperature readings. The thermocouple on the back of each probe showed a steady decrease throughout the day, suggesting a deposition layer building up slowly over time and remaining in place. Operation during the time period shown in these figures was characterized by downcomer plugging and very high pressure drop in the combustor and downcomer.

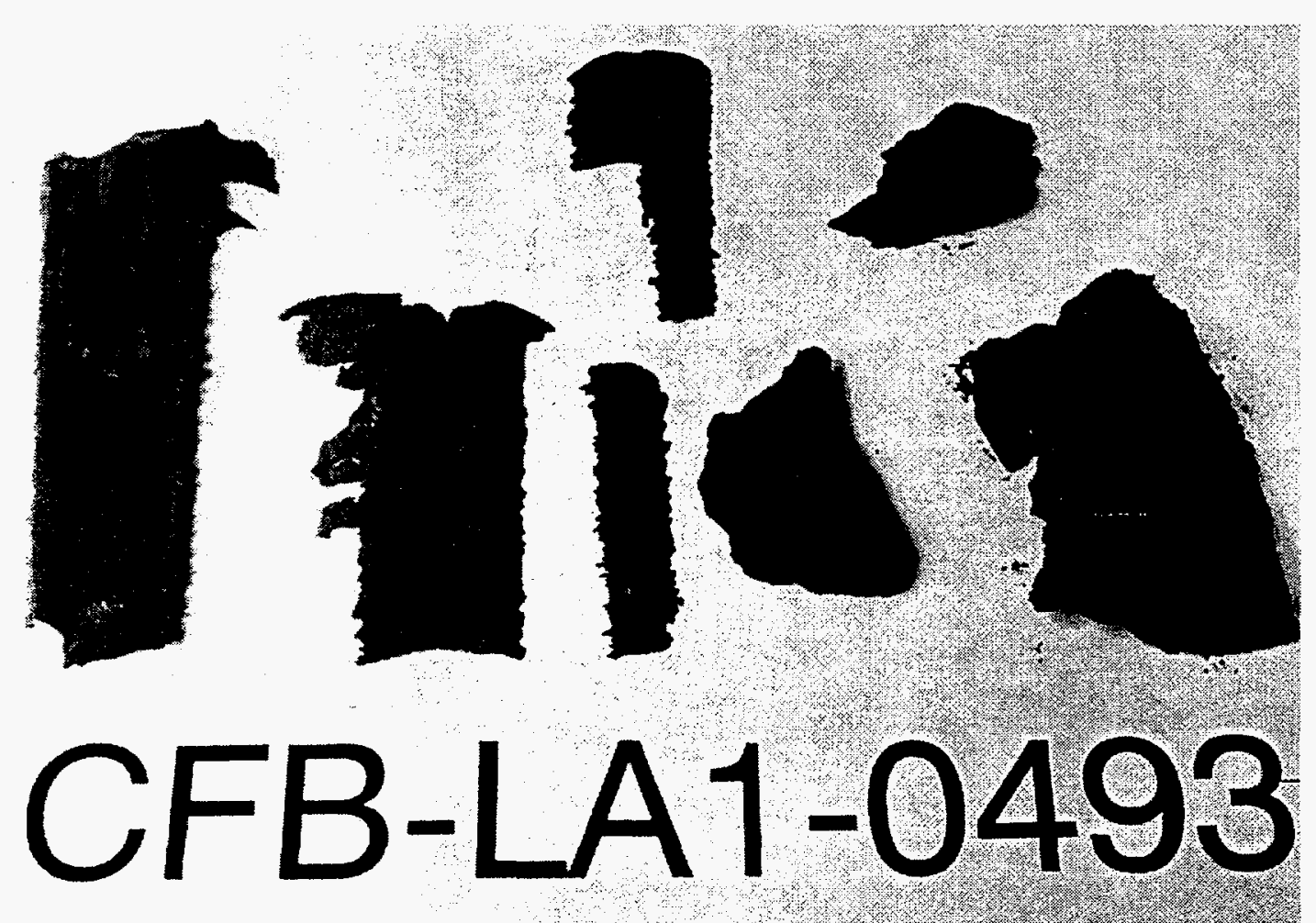

Figure 4-13. Deposits formed on the ash-fouling probes during the DMSS test. 


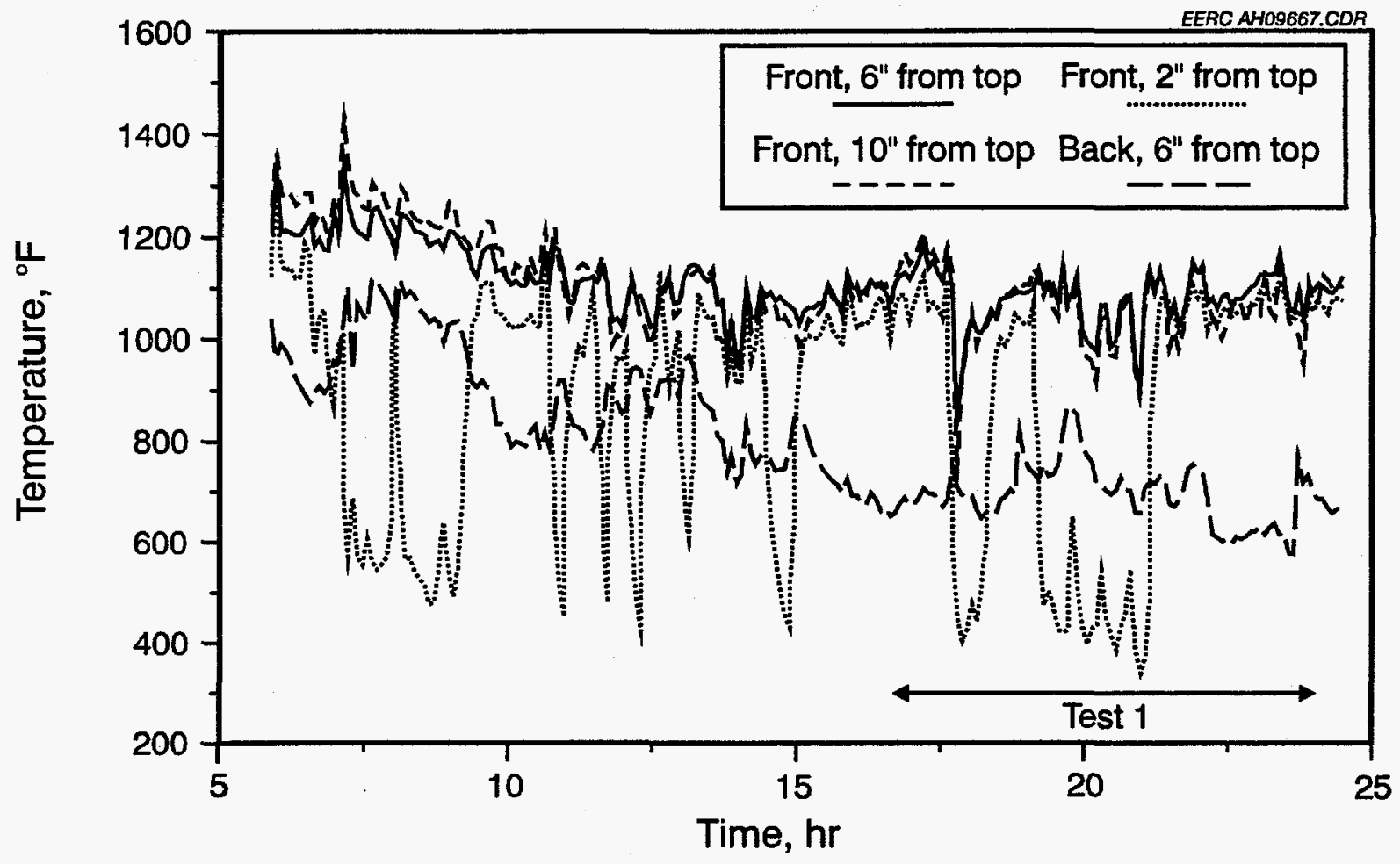

Figure 4-14. East ash-fouling probe temperatures, during the second day of DMSS testing.

Figure 4-15, showing the east probe temperatures for the fourth day of the run, illustrates that the temperatures were more uniform later in the week and that the temperature at the back of each probe was typically lower than those measured at the probe's leading edge.

The deposits from the probes were analyzed by XRFA and XRD with a SEM to provide insight on their method of formation. Table 4-4 presents the average chemical composition of the deposits. The ash that goes by the ash-fouling probes is collected in the secondary cyclone. Therefore, one may expect the composition of these two streams to be similar. A significant difference is noticed between the fly ash and the deposit, namely, a higher calcium and sulfur level in the deposit as compared to the fly ash. This indicates that the fine calcium particles are selectively depositing on the ash-fouling probes. Once the ash is deposited, the calcium is being sulfated, which provides strength to the deposit, as confirmed by a comparison of the calcium-to-sulfur ratios for the ash versus the deposits. The SEM analyses show that the hard, thin deposit consists of ash particles mixed in a matrix of fine-grained $\mathrm{CaSO}_{4}$, where the $\mathrm{CaSO}_{4}$ is the primary bonding material. The large, soft deposit on the back side of the probe is more loosely bonded, with a larger quantity of ash particles intermixed with the $\mathrm{CaSO}_{4}$ matrix. 


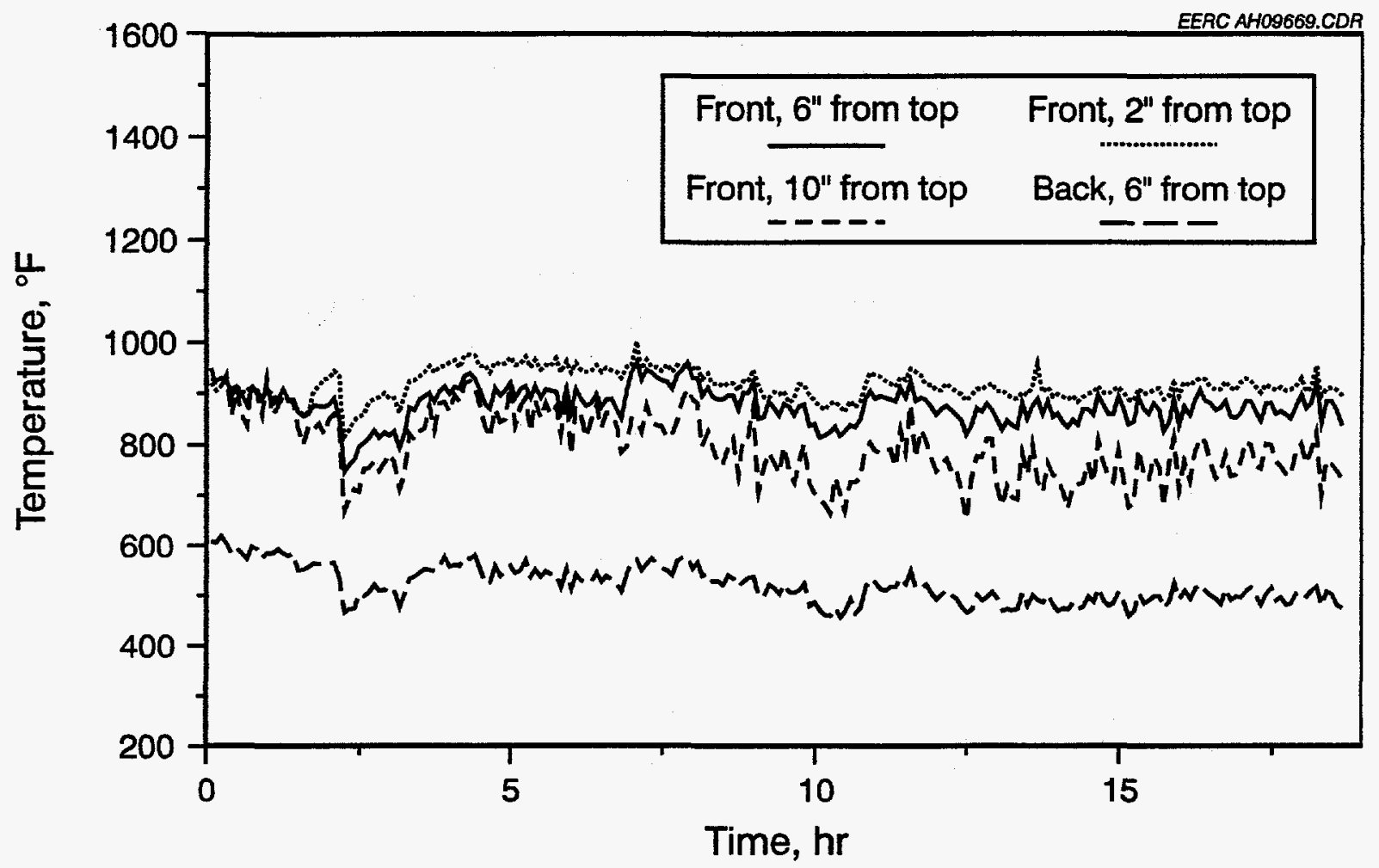

Figure 4-15. East ash-fouling probe temperatures during the fourth day of DMSS testing.

TABLE 4-4

Elemental Analysis of Ash and Deposits from DMSS Firing wt \% on an $\mathrm{SO}_{3}$-free basis

\begin{tabular}{lrrrr} 
& DMSS & $\begin{array}{c}\text { Secondary } \\
\text { Cyclone }\end{array}$ & $\begin{array}{c}\text { Thin } \\
\text { Deposit }\end{array}$ & $\begin{array}{c}\text { Thick } \\
\text { Deposit }\end{array}$ \\
\hline $\mathrm{SiO}_{2}$ & 26.9 & 23.3 & 10.6 & 16.8 \\
$\mathrm{Al}_{2} \mathrm{O}_{3}$ & 9.6 & 6.3 & 12.7 & 4.4 \\
$\mathrm{Fe}_{2} \mathrm{O}_{3}$ & 22.1 & 13.2 & 7.2 & 10.3 \\
$\mathrm{TiO}_{2}$ & 0.4 & 0.5 & 0.3 & 0.3 \\
$\mathrm{P}_{2} \mathrm{O}_{5}$ & 23.4 & 17.8 & 10.3 & 13.4 \\
$\mathrm{CaO}$ & 13.4 & 33.4 & 63.2 & 47.7 \\
$\mathrm{MgO}$ & 2.7 & 3.5 & 5.1 & 5.7 \\
$\mathrm{Na}_{2} \mathrm{O}$ & 1.1 & 1.1 & 0.2 & 0.6 \\
$\mathrm{~K}_{2} \mathrm{O}$ & 0.5 & 0.6 & 0.5 & 0.6 \\
$\mathrm{Total}$ & 100.0 & 100.0 & 100.0 & 100.0 \\
$\mathrm{SO}_{3}$ & 7.8 & 14.9 & 45.4 & 34.8 \\
$\mathrm{Ca} / \mathrm{S}$ & 3.2 & 3.8 & 1.5 & 1.8 \\
\hline
\end{tabular}




\subsection{Summary}

The tendency for each of the fuels to form deposits and agglomerates in the CFBC pilot plant are summarized in Tables 4-5 and 4-6. Agglomeration was less prevalent than deposition and was noted only for the Center lignite and the petroleum cokes. The agglomeration for the Center lignite was undoubtedly related to the sodium content in the lignite. It is less clear what initiated the agglomeration in the petroleum coke cases; however, it is speculated that local reducing conditions provide the opportunity for low-temperature eutectics of either $\mathrm{CaS}$ and $\mathrm{CaSO}_{4}$ to form, or possibly of $\mathrm{CaSO}_{4}$ and $\mathrm{V}_{2} \mathrm{O}_{5}$. Mechanisms will be discussed in later sections of this report.

Some deposition occurred during firing of most of the test fuels. Deposits formed on the refractory surfaces of the primary cyclone and downcomer and on the ash-fouling probes that were designed to simulate the leading edge of the convective pass. Generally speaking, the deposits were made of fine-grained (1- to 10-micron) calcium sulfate. In many cases, the deposits were soft and would slough off of the surfaces because of their own weight. A notable difference was the degree of sulfation of the deposited material. In all cases, the deposit was more sulfated than the ash collected in the secondary cyclone. Also, deposits formed when firing high-sulfur fuels were more sulfated than those from low-sulfur fuels. It was also observed that the more sulfated deposits tended to show higher strength than the less sulfated deposits.

The following hypothesis, along with some observations and comments, is provided on the deposit formation. The mechanisms of formation for the thick backside deposits are likely eddy impaction and thermophoresis. Mostly small particles of less than 10 microns follow the stream lines around the tubes and impact as a result of eddy currents. It appears that the primary component of the deposit is partially sulfated limestone. The cementing agent loosely holding the deposit particles together appears to be partially sulfated limestone that continues to become more fully sulfated over time, resulting in continued particle growth. The deposit probably reaches an equilibrium size, at which time it falls off under its own weight. It does not seem that the large deposits on the back side of the probes would represent a serious fouling problem. They are relatively soft, although they could become hard deposits if permitted to stay on the boiler tubes for an extended period of time. It would seem prudent to at least leave room in the higher-temperature regions of the convective pass for the installation of sootblowing capabilities. The hard deposits on the front side of the probes would be more difficult to remove. A more detailed discussion of deposition mechanisms is presented later in this report. 
TABLE 4-5

Occurence of Agglomeration When Firing Various Fuels in the EERC CFBC

\begin{tabular}{|c|c|c|}
\hline Fuel & Agglomeration & Notes \\
\hline Delayed Coke & Yes & $\begin{array}{l}\text { Small agglomerates; } 55 \% \mathrm{CaSO}_{4} \text { with } \\
35 \% \mathrm{SiO}_{4} \text { (from start-up bed); V } \\
\text { associated with AlCaSiS systems }\end{array}$ \\
\hline Sewage Sludge (DMSS) & No & Larger "rocks" found in bed drain \\
\hline Thailand Lignite & No & Buildup of clay and rocks in bed \\
\hline Center Lignite & Yes & $\begin{array}{l}\text { Many } 1 / 8-\text { in. and some } 1 \text {-in. diameter } \\
\text { agglomerates found }\end{array}$ \\
\hline Powder River & No & \\
\hline New Mexico & No & \\
\hline Fluid Coke & Yes & $\begin{array}{l}\text { Total sintering of bed at }-1725^{\circ} \mathrm{F} \text { and } \\
\text { stoichiometric air. }\end{array}$ \\
\hline Salt Creek & No & \\
\hline Blacksville & No & \\
\hline Black Thunder & No & \\
\hline
\end{tabular}


TABLE 4-6

Occurrence of Deposition When Firing Various Fuels in the EERC CFBC

\begin{tabular}{|c|c|c|}
\hline FUELS & DEPOSITION & NOTES \\
\hline Delayed Coke & Yes & $\begin{array}{l}\text { Soft deposits; fully sulfated; particles }<50 \mu \mathrm{m} ; \mathrm{V} \\
\text { associated with ash particles. }\end{array}$ \\
\hline $\begin{array}{l}\text { Sewage Sludge } \\
\text { (DMSS) }\end{array}$ & Yes & $\begin{array}{l}\text { Hard, thin deposits of fully sulfated } \mathrm{CaSO}_{4} \text { on } \\
\text { leading edge of probes; soft thick deposits } \\
\text { partially sulfated } \mathrm{CaSO}_{4} \text { on back side of probes } \\
\text { with some ash inclusions; surface temperature } \\
\text { indicates deposits slough off of tubes; frequent } \\
\text { downcomer plugging with deposits in cyclone } \\
\text { barrel. }\end{array}$ \\
\hline Thailand Lignite & Yes & $\begin{array}{l}\text { Thin (1-mm) layer on deposition probes; hard, } \\
\text { fine-grained }(<10 \mu \mathrm{m}) \mathrm{CaSO}_{4} \text { deposit on tube } \\
\text { sheet of tube-and-shell heat exchanger }\end{array}$ \\
\hline Center Lignite & Yes & $\begin{array}{l}\text { Thin deposit (1-mm) on cooled probes; thick } \\
\text { (1/4-in.) deposit on uncooled probes; hard deposits } \\
\text { on refractory walls; deposit composition } \mathrm{CaSO}_{4} \\
\text { and } \mathrm{Ca}_{5}\left(\mathrm{PO}_{4}\right)_{3} \mathrm{OH} \text {; deposit particles } 1 \text { to } 10 \mu \mathrm{m} \text {. }\end{array}$ \\
\hline Powder River & Yes & $\begin{array}{l}\text { Soft deposit on downstream side of probes that } \\
\text { sloughed off; deposits consist of }<10 \mu \mathrm{m} \text { partially } \\
\text { sulfated particles. }\end{array}$ \\
\hline New Mexico & No & Light dusting of probes noted. \\
\hline Fluid Coke & Yes & $\begin{array}{l}\text { Soft, fine-grained } \mathrm{CaSO}_{4} \text { on bottom of cyclone } \\
\text { and downcomer. }\end{array}$ \\
\hline Salt Creek & Yes & $\begin{array}{l}\text { Soft, partially sufated } \mathrm{CaSO}_{4} \text { deposits on } \\
\text { downcomer walls. }\end{array}$ \\
\hline Blacksville & No & \\
\hline Black Thunder & No & Light dusting of probes. \\
\hline
\end{tabular}


5.0

BENCH-SCALE TESTING 


\section{TABLE OF CONTENTS}

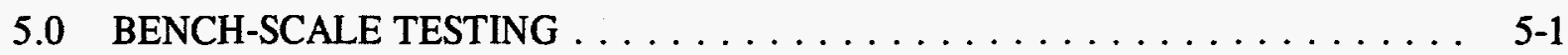

5.1 Bench-Scale Test Objectives $\ldots \ldots \ldots \ldots \ldots \ldots \ldots \ldots \ldots \ldots \ldots$. . . . . . . .

5.2 Description of Pressurized Fluidized-Bed Reactor . . . . . . . . . . . 5-1

5.3 Test Matrix . . . . . . . . . . . . . . . . . . . . . . . 5-4

5.4 Results from Bench-Scale Tests $\ldots \ldots \ldots \ldots \ldots \ldots \ldots \ldots \ldots$

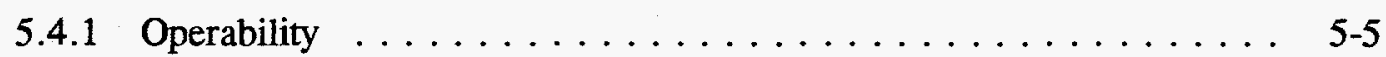

5.4 .2 Agglomeration and Deposition Tendencies . . . . . . . . . . 5-8

5.4 .3 Bulk Chemistry . . . . . . . . . . . . . . . . . . . 5-13

5.4 .4 Morphology . . . . . . . . . . . . . . . . . . 5-17

5.4.5 Validation With Full-Scale Data .............. 5-20

\section{LIST OF FIGURES}

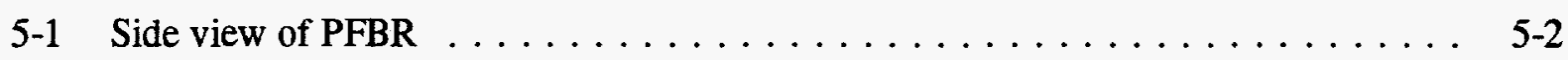

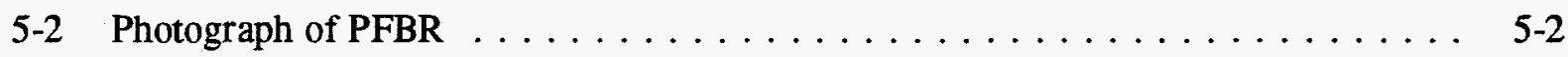

5-3. Photograph of PFBR in external heat jacket with auxiliaries installed . . . . . . 5-3

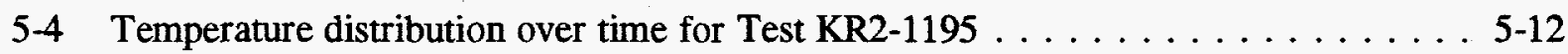

5-5 Temperature distribution over time for Test $\mathrm{KR} 2-1295 \ldots \ldots \ldots \ldots \ldots$. . . . . .

5-6 Temperature distribution for three bench-scale tests $\ldots \ldots \ldots \ldots \ldots \ldots \ldots \ldots$

5-8 Chemical composition of bed material over time for Test KR1-0295 . . . . . . 5-14

5-7 Chemical composition of bed material over time for Test KR1-0195 . . . . . . 5 5-14

5-9 Chemical composition of bed material over time for Test KR1-0595 . . . . . . 5-15

5-10 Chemical composition of bed material over time for Test KR1-0695 . . . . . 5 5-15

5-11 Chemical composition of bed material over time for Test KR2-2295 . . . . . 5-16

5-12 Chemical composition of bed material over time for Test B1-1395 . . . . . 5-16

5-13 Line scan of coated bed particle from Test KR2-1295 . . . . . . . . . . . 5-18

5-14 Line scan of a 4-hour bed particle from Test KR2-2295 . . . . . . . . . . 5 5-19

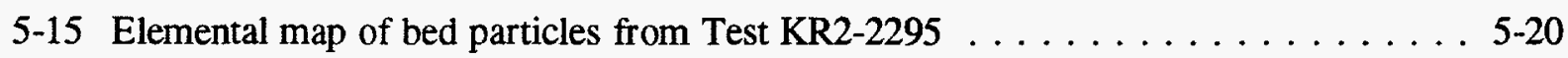

5-16 Line scan of a 16-hour bed particle from Test KR2-2295 . . . . . . . . . . 5-21 


\section{LIST OF TABLES}

5-1 Proposed Screening Matrix for North Dakota Lignite Tests . . . . . . . . 5-4

5-2 As-Run Test Matrix for North Dakota Lignite $\ldots \ldots \ldots \ldots \ldots \ldots \ldots$ 5-6

5-3 Fuel Analyses for Bench-Scale Tests $\ldots \ldots \ldots \ldots \ldots \ldots \ldots \ldots \ldots$ 5-7

5-4 Operating Conditions for Bench-Scale Tests $\ldots \ldots \ldots \ldots \ldots \ldots \ldots$ 5-9

5-5 Emissions for Bench-Scale Tests $\ldots \ldots \ldots \ldots \ldots \ldots \ldots \ldots \ldots \ldots$ 5-10

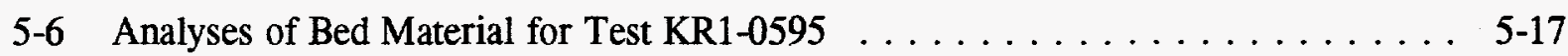

5-7 Analyses of Bed Material for Test KR2-1295 $\ldots \ldots \ldots \ldots \ldots \ldots \ldots \ldots$ 5-18

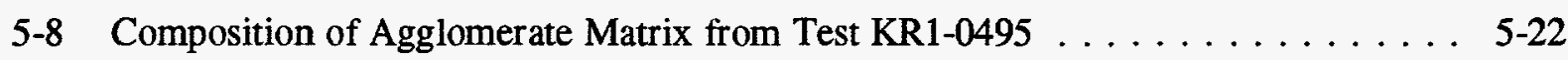

5-9 Chemical Composition of Agglomerate from Test KR1-0695 . . . . . . . . . 5-22

5-10 Comparison of Chemical Compositions of Bed Material Coating

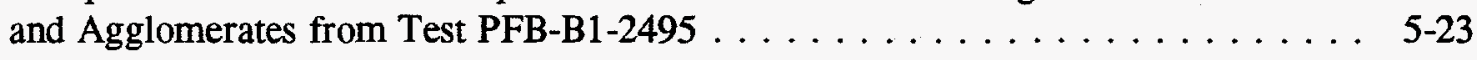

5-11 Comparison of Bulk Analyses at Bench Scale and Full Scale $\ldots \ldots \ldots \ldots$. . . . . .

5-12 Comparison of Bed Material Coatings from EERC and Heskett . . . . . . . . 5-24

5-13 Analyses of Selected Points from Heskett Agglomerate $\ldots \ldots \ldots \ldots \ldots$. . . . . . .

5-14 Analyses of Selected Points from EERC Agglomerate (KR1-0295) . . . . . . 5 5-24

5-15 Comparison of Heskett and EERC Deposits $\ldots \ldots \ldots \ldots \ldots \ldots \ldots \ldots$ 5-25 


\subsection{BENCH-SCALE TESTING}

\subsection{Bench-Scale Test Objectives}

The overall objectives of the bench-scale testing were to 1) develop a tool that can be used to predict agglomeration and deposition, 2) develop data that will lead to a mechanism for deposition and agglomeration, 3 ) determine variables important in the agglomeration process, 4) determine rates of deposition and agglomeration, and 5) develop mitigating measures. A bench-scale reactor was specifically designed and constructed to meet these objectives. Tests were performed to determine the impact of fuel characteristics, bed material characteristics, sorbent characteristics, and operating parameters on deposition and agglomeration.

\subsection{Description of Pressurized Fluidized-Bed Reactor}

A pressurized fluidized-bed reactor (PFBR) has been constructed to simulate the bed chemistry, ash interactions, and emissions from a PFB under closely controlled conditions. This reactor is used for sorbent characterization, gaseous emissions including trace elements, agglomeration, and hot-gas cleanup testing in a cost-effective manner over a wide range of operational conditions. The 55-in.-tall reactor is constructed of 3-in. Schedule 80 pipe and is externally heated with three ceramic heaters. A hot cyclone collects the ash and bed material that is carried out of the reactor. The preheated fluidizing gas can be a mixture of air and nitrogen or just air, and one additional gas such as carbon dioxide, carbon monoxide, sulfur dioxide, or a nitrogen oxide can be added to result in a fuel gas similar to that generated in a full-scale fluidized-bed combustor. Preheated gas at temperatures up to $1400^{\circ} \mathrm{F}$ and pressures up to 200 psig are supplied at the bottom of the reactor through a 1 -in. Schedule 40 pipe. The fluidizing gas is supplied at sufficiently high velocities to prevent the sized bed material from dropping out during operation.

The fluidizing gas enters into the 3 -in. Schedule 80 main section of the reactor through a conical transition. This conical section was designed without a distributor plate to allow quick removal and quench of the bed material after completion of a test. Bed material can be sampled or collected using a lock hopper system located at the bottom of the reactor. Figure 5-1 is a side view of the reactor and cyclone. Figure 5-2 is a photograph of the actual reactor vessel, cyclone, air preheater, reactor collection pot, and fuel feed hopper. Figure 5-3 is a photograph of the final system after the external heaters and other auxiliaries have been installed.

The use of electric heaters provides the capability to match the fuel feed rate to the amount of bed material in the reactor. External heaters will be used for heating and maintaining the reactor and hot cyclone at temperatures up to $2000^{\circ} \mathrm{F}$ for atmospheric operation and up to $1700^{\circ} \mathrm{F}$ for operation at $150 \mathrm{psig}$. The external ceramic heaters on the gas preheater and the reactor itself are rated at 10.8 and $10.05 \mathrm{~kW}$, respectively, with an upper temperature limit of $1200^{\circ} \mathrm{F}$. In a full-scale system, the bed is deep relative to that in the PFBR. Therefore, to keep the coal feed rate-to-bed inventory similar between bench- and full-scale systems, the coal feed rate in the PFBR is kept low relative to full-scale systems, compared on a fuel feed rate per bed cross-sectional area basis. Therefore, additional heat is required to maintain the desired temperature. The high heat losses through the reactor walls inherent 


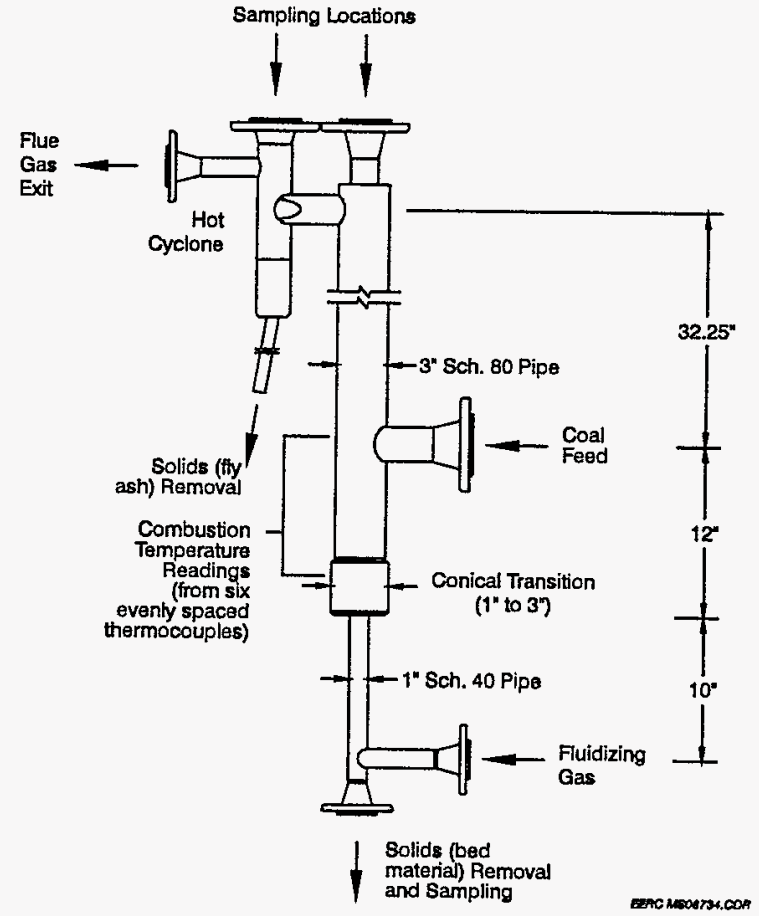

Figure 5-1. Side view of PFBR.

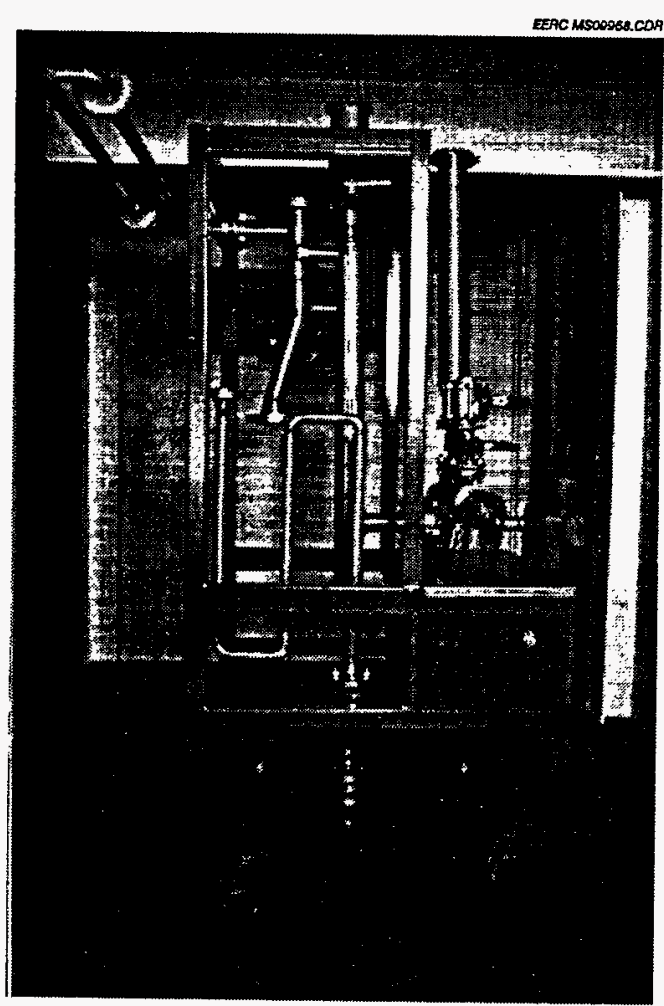

Figure 5-2. Photograph of PFBR. 


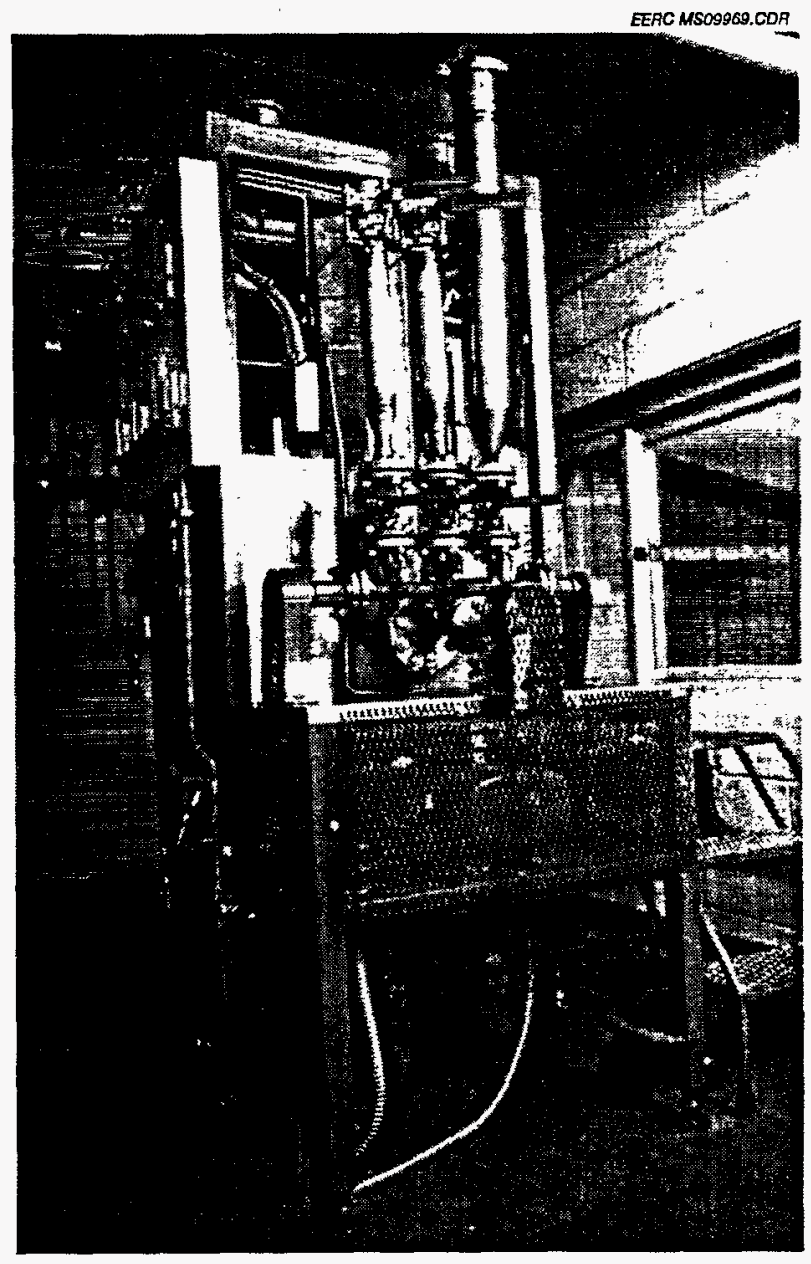

Figure 5-3. Photograph of PFBR in external heat jacket with auxiliaries installed.

to small-scale systems also require either good insulation or reactor heating. This type of heating system provides very good control of the reactor temperature. The use of both air and nitrogen as fluidizing gas allows excess air quantities and gas velocity to be matched to any design condition.

Dry coal and sorbent are metered with separate augers that feed into a common watercooled auger, which in turn carries the material into the reactor. A bed material hopper empties directly into the common auger, without flow control. Each hopper will be maintained at a pressure slightly higher than that in the combustor during operation. The hoppers can be isolated from the pressurized system so that they can be refilled during a test. A data acquisition and control system is used to monitor and record all critical pressures, temperatures, flow rates, and emissions and to remotely control the numerous valves distributed throughout the system. These critical data include the gas flow rates, bed static and differential pressures across the bed and cyclone, eight different internal reactor temperatures, and coal feed rate, as well as information monitored from other operating conditions and gaseous emissions. Ports for alkali sampling probes or, alternatively, solid-sampling or gas-sampling probes are located at the top of the reactor and the top of the cyclone. 
Several methods have been identified for determining the extent and cause of deposition and agglomeration. Evidence of agglomeration was determined from pressure and temperature fluctuations, by visual observation of the bed during operation, and by visual observation of bed condition after the test. The rate and extent of agglomeration was determined from sieve and SEM morphology/image analyses. The thickness of ash coatings that build up on the bed particles was determined as a function of time. Methods to determine the mechanisms of agglomeration included XRD and XRFA for bulk mineral and elemental composition, SEMPC for mineral composition, SEM morphology of elemental mapping, sintering (dilatometer), and thermogravimetric analysis-differential thermal analysis (TGA-DTA).

\subsection{Test Matrix}

A large number of variables exist as possible factors in the development of bed agglomerates. These factors may be categorized as fuel characteristics, bed material characteristics, sorbent characteristics, and operating parameters. Because of the size of the test matrix, if all combinations of all variables were tested, it was determined that the most efficient use of resources for this effort was to do an extensive screening with one fuel and more limited testing of additional fuels. The fuel chosen for the initial screening matrix was a North Dakota lignite. Table 5-1 shows the original test matrix with this fuel.

The shakedown tests with this fuel revealed some problems with the desired operating conditions. Little agglomeration was observed after 24 hours of operation with a Beulah lignite containing about $4 \%$ sodium in the ash; a high-sodium (12\%-14\%) lignite was used thereafter to obtain measurable differences in bed chemistry in a reasonably short period of time (16 hours was chosen as a standard test length). Other operating variables were adjusted to minimize the duration of each test. For example, a relatively large-size bed material $\left(\mathrm{d}_{50}=1400 \mu \mathrm{m}\right)$, combined with a superficial gas velocity of $6 \mathrm{ft} / \mathrm{sec}$ to simulate the ratio of actual velocity to minimum fluidization velocity, increased the required air flow enough to allow for an increase in coal feed rate, which offers the potential for a more rapid buildup of coatings on the bed material. The addition of an in-bed cooling coil, which can use either air or water as the cooling medium, allowed for a further increase in the coal feed rate. However, the coal feed rate was so high with the water-cooled coil that the limited coal supply for the planned tests

TABLE 5-1

Proposed Screening Matrix for North Dakota Lignite Tests

\begin{tabular}{lcccc}
\hline Temperature, ${ }^{\circ} \mathrm{F}$ & $\begin{array}{c}\text { Excess } \\
\text { Air, \% }\end{array}$ & $\begin{array}{c}\text { Velocity, } \\
\mathrm{ft} / \mathrm{sec}\end{array}$ & $\begin{array}{c}\text { Fuel Feed } \\
\text { Rate }\end{array}$ & $\begin{array}{c}\mathrm{SO}_{2}, \\
\mathrm{ppm}\end{array}$ \\
\hline 1500 & 0 & 3 & $\mathrm{~A}^{1}$ & $\mathrm{~B}^{2}$ \\
1500 & 30 & 3 & $\mathrm{~A}$ & $\mathrm{~B}$ \\
1700 & 0 & 3 & $\mathrm{~A}$ & $\mathrm{~B}$ \\
1700 & 30 & 3 & $\mathrm{~A}$ & $\mathrm{~B}$ \\
1600 & 15 & 3 & $\mathrm{~A}$ & $\mathrm{~B}$ \\
1600 & 15 & 6 & $\mathrm{~A}$ & $\mathrm{~B}$ \\
1600 & 15 & 3 & $2 \mathrm{~A}$ & $\mathrm{~B}$ \\
1600 & 15 & 3 & $\mathrm{~A}$ & $\mathrm{~B}+2000$ \\
\hline
\end{tabular}

1 Feed rate equivalent to Heskett as $\left.\left([\mathrm{Btu} / \mathrm{hr}] / \mathrm{ft}^{2}\right]\right) / \mathrm{bed}$ depth.

${ }^{2} \mathrm{SO}_{2}$ rate generated from coal combustion. 
would be exhausted before the entire test matrix could be completed. Therefore, the coil was air-cooled for the remainder of the tests. For the first three tests with the Beulah lignite, the coal was sized to $-1 / 4$ in., but it was determined that the feed rate was not uniform at this size, as evidenced by high fluctuations in the excess air level. All subsequent tests have been performed with $-1 / 8$ in. coal size.

Because of the operating changes listed above, the proposed test matrix was modified. Fuel feed rate and velocity were eliminated as test variables. While fuel properties were considered to be an important parameter in this program, availability of fuels for testing was a problem. As a result, all of the tests on the bench-scale reactor were performed with North Dakota lignite. In addition to the operating parameters of temperature and excess air, other parameters tested were bed material type, sorbent type, and $\mathrm{SO}_{2}$ addition. The actual test matrix is shown in Table 5-2. The test number designations of KR1, KR2, and B1 refer to three different shipments of coal. Coal B1 was used for start-up as well as for Test 1395. The analyses for these three coals are shown in Table 5-3.

\subsection{Results from Bench-Scale Tests}

\subsubsection{Operability}

Overall operability of the FBR during these tests was good. Certain problems were encountered, mainly due to the small size of the unit, but adjustments were made to the method of operation to minimize operating difficulties. Air was introduced at the bottom of the reactor to achieve the desired excess air level and velocity. In some cases, nitrogen flow was added to fine-tune the velocity without affecting the excess air level. Air and nitrogen flow rates were controlled automatically to flow rate set points. Temperature was controlled by maximizing coal feed rate, then using the three ceramic heaters to maintain each reactor zone at a given gas temperature. Bed material and cyclone ash samples were taken approximately every 4 hours for the duration of each test. A computer-controlled valve allows for the collection of a small amount of bed material.

Operation of bench-scale tests with lignite did present some difficulties. The fuel tended to "bridge" in the exit of the fuel hopper because of its high moisture content $(31.2 \%)$. When fuel feed was temporarily lost, the FBR temperature would drop as much as $200^{\circ} \mathrm{F}$, and excess air would increase dramatically. In some cases it took up to 30 minutes to regain steady-state conditions. It was necessary to add a vibrator to the fuel auger, in addition to periodic banging on the hopper to improve fuel feed. To lessen these problems, the fuel was air-dried to a moisture content of about $21 \%$, and sized to $-1 / 8$ in.

During some of the tests, the sample line to the flue gas analyzers became plugged with fine ash, requiring periodic attention to maintain analyzer readings. Ash buildup also occurred at the entrance to the cyclone.

Two tests were repeated: the low-temperature, high-excess air test, KR1-0195, and the high-temperature, high-excess air test, KR1-0295. KR1-0195 was repeated because the high calcium content of the washed sand bed material provided inherent sulfur capture, affecting the 
TABLE 5-2

As-Run Test Matrix for North Dakota Lignite

\begin{tabular}{|c|c|c|c|c|c|}
\hline $\begin{array}{l}\text { Test } \\
\text { Number }\end{array}$ & $\begin{array}{c}\text { Bed } \\
\text { Temp. }{ }^{\circ} \mathrm{F} \\
\end{array}$ & $\begin{array}{l}\text { Excess } \\
\text { Air, \% }\end{array}$ & $\begin{array}{c}\text { Bed } \\
\text { Material } \\
\end{array}$ & Additive & Results \\
\hline KR1-0195 & 1500 & 30 & Washed sand & None & Ran 16 hr \\
\hline KR1-0295 & 1700 & 30 & $\# 30$ Red Flint sand & None & $\begin{array}{l}\text { Ran } 15 \mathrm{hr} \text {; air flow rate } \\
\text { unknown. Trouble with } \\
\text { reactor heaters }\end{array}$ \\
\hline KR1-0395 & 1600 & 15 & \#30 Red Flint sand & None & $\begin{array}{l}\text { Temperatures unstable; } \\
\text { defluidized after } 5 \mathrm{hr}\end{array}$ \\
\hline KR1-0495 & 1700 & 2.5 & $\# 30$ Red Flint sand & None & Defluidized after $3 \mathrm{hr}$ \\
\hline KR1-0595 & 1500 & 2.5 & $\# 30$ Red Flint sand & None & $\operatorname{Ran} 16 \mathrm{hr}$ \\
\hline KR1-0695 & 1700 & 30 & $\# 30$ Red Flint sand & None & $\begin{array}{l}\text { Ran } 8.5 \mathrm{hr} \text {, until coal } \\
\text { supply ran out }\end{array}$ \\
\hline $\mathrm{KR} 2-0795^{2}$ & 1500 & 30 & \#30 Red Flint sand & None & Defluidized after $40 \mathrm{~min}$ \\
\hline KR2-1095 & 1500 & 30 & $\# 30$ Red Flint sand & None & Defluidized after $1 \mathrm{hr}$ \\
\hline KR2-1195 & 1500 & 30 & \#30 Red Flint sand & $\begin{array}{c}0.029 \\
\text { lb kaolin/ } \\
\text { lb coal }\end{array}$ & Defluidized after $1.4 \mathrm{hr}$ \\
\hline KR2-1295 & 1500 & 30 & \#30 Red Flint sand & $\begin{array}{l}0.093 \mathrm{lb} \\
\text { kaolin } / \\
\text { lb coal }\end{array}$ & $\operatorname{Ran} 16 \mathrm{hr}$ \\
\hline B1-1395 & 1500 & 30 & \#30 Red Flint sand & None & Ran $113 \mathrm{hr}$ \\
\hline KR2-1495 & 1600 & 15 & \#30 Red Flint sand & None & $\begin{array}{l}\text { Defluidized after } 1.85 \mathrm{hr} \text {; } \\
\text { tried again and ran } 50 \mathrm{~min}\end{array}$ \\
\hline KR2-1595 & 1700 & 30 & \#30 Red Flint sand & None & Defluidized after $2.95 \mathrm{hr}$ \\
\hline KR2-1695 & 1700 & 30 & \#30 Red Flint sand & $\begin{array}{l}2000 \mathrm{ppm} \\
\mathrm{SO}_{2}\end{array}$ & Defluidized after $3.33 \mathrm{hr}$ \\
\hline KR2-1795 & 1500 & 30 & \#30 Red Flint sand & $\begin{array}{l}2000 \mathrm{ppm} \\
\mathrm{SO}_{2}\end{array}$ & Defluidized after $6.28 \mathrm{hr}$ \\
\hline KR2-1895 & 1500 & 30 & $\# 30$ Red Flint sand & $\begin{array}{c}0.039 \mathrm{lb} \\
\text { dolomite/ } \\
\mathrm{lb} \text { coal }\end{array}$ & $\begin{array}{l}\text { Defluidized after } 0.93 \\
\text { hours; tried again and ran } \\
2.38 \mathrm{hr}\end{array}$ \\
\hline KR2-1995 & 1500 & 30 & $\begin{array}{c}-10+20 \text { mesh } \\
\text { Gabbro }\end{array}$ & None & Defluidized after $9.5 \mathrm{hr}$ \\
\hline KR2-2095 & 1500 & 30 & $\begin{array}{l}-10+20 \text { mesh } \\
\text { dolomite }\end{array}$ & None & Bed material blew over \\
\hline KR2-2295 & 1600 & 30 & $\begin{array}{c}-10+20 \text { mesh } \\
\text { limestone }\end{array}$ & None & Ran $16 \mathrm{hr}$ \\
\hline KR2-2395 & 1500 & 30 & \#30 Red Flint sand & $\begin{array}{c}0.032 \mathrm{lb} \\
\text { limestone/ } \\
\text { lb coal }\end{array}$ & Defluidized after $3.1 \mathrm{hr}$ \\
\hline
\end{tabular}

Repeat of KR1-0295, using air instead of water cooling.

2 Repeat of KR1-0195, using air instead of water cooling and using Red Flint Sand as bed material. 
TABLE 5-3

Fuel Analyses for Bench-Scale Tests

\begin{tabular}{|c|c|c|c|}
\hline $\begin{array}{l}\text { Mine: } \\
\text { Rank: }\end{array}$ & $\begin{array}{c}\text { Knife River } \\
\text { Lignite }\end{array}$ & $\begin{array}{c}\text { Knife River } \\
\text { Lignite }\end{array}$ & $\begin{array}{l}\text { Beulah } \\
\text { Lignite } \\
\end{array}$ \\
\hline \multicolumn{4}{|c|}{ Proximate Analysis, as received, wt\% } \\
\hline Moisture & 21.12 & 21.00 & 23.00 \\
\hline Volatile Matter & 36.84 & 37.52 & 35.11 \\
\hline Fixed Carbon & 36.52 & 35.68 & 28.49 \\
\hline Ash & 5.52 & 5.80 & 13.40 \\
\hline \multicolumn{4}{|c|}{ Ultimate Analysis, as received, wt $\%$} \\
\hline Carbon & 52.33 & 52.05 & 43.75 \\
\hline Hydrogen & 3.31 & 3.29 & 2.66 \\
\hline Nitrogen & 0.73 & 0.72 & 0.55 \\
\hline Sulfur & 0.57 & 0.80 & 2.39 \\
\hline Oxygen & 16.43 & 16.34 & 14.22 \\
\hline Ash & 5.52 & 5.80 & 13.42 \\
\hline Moisture & 21.12 & 21.00 & 23.00 \\
\hline \multicolumn{4}{|c|}{ Ash Composition, \% as oxides } \\
\hline Calcium, $\mathrm{CaO}$ & 27.66 & 23.95 & 12.00 \\
\hline Magnesium, MgO & 10.38 & 9.86 & 6.90 \\
\hline Sodium, $\mathrm{Na}_{2} \mathrm{O}$ & 12.66 & 13.88 & 3.40 \\
\hline Silica, $\mathrm{SiO}_{2}$ & 11.01 & 14.94 & 24.50 \\
\hline Aluminum, $\mathrm{Al}_{2} \mathrm{O}_{3}$ & 9.64 & 7.60 & 11.40 \\
\hline Ferric, $\mathrm{Fe}_{2} \mathrm{O}_{3}$ & 7.13 & 4.09 & 19.10 \\
\hline Titanium, $\mathrm{TiO}_{2}$ & 0.09 & 0.23 & 0.60 \\
\hline Phosphorus, $\mathrm{P}_{2} \mathrm{O}_{5}$ & 1.24 & 0.45 & 0.30 \\
\hline Potassium, $\mathrm{K}_{2} \mathrm{O}$ & 0.31 & 0.30 & 0.10 \\
\hline Sulfur, $\mathrm{SO}_{3}$ & 19.88 & 24.72 & 21.70 \\
\hline \multicolumn{4}{|l|}{ High_Heating Value } \\
\hline $\begin{array}{l}\text { Moisture-Free, } \\
\text { Btu/lb }\end{array}$ & 11,105 & 11,130 & 9203 \\
\hline $\begin{array}{l}\text { As-Received, } \\
\text { Btu/lb }\end{array}$ & 8760 & 8793 & 7086 \\
\hline
\end{tabular}

agglomeration potential for that test. Red Flint sand was used for the remaining tests. The second low-temperature, high-excess air test, KR2-0795, defluidized after 40 minutes of peration. Test KR1-0295 was repeated because of an error in the calibration of the air flow measurement, which resulted in an actual air flow and, therefore, a velocity much higher than desired. The second high-temperature, high-excess air test, KR1-0695, lasted $8.5 \mathrm{hr}$. Both repeated tests were performed using air in the cooling coil in order to be consistent with Tests KR1-0395 through KR1-0595. The three designations for Test KR2-0795 indicate three separate attempts to perform the test. The first two attempts defluidized in less than 1 hour each; the third test ran for 3 hours before being terminated because of plugging in the cyclone. 
Since the effect of the plugged cyclone on the first two tests of Test KR2-0795 is unknown, this test was be repeated one more time, as Test KR2-1095. This test defluidized in 1 hour, validating the results of Test KR2-0795.

Tests KR2-2095 and KR2-2195 were two attempts at using dolomite, sized to $-100+20$ mesh, as the bed material. Test 2095 was terminated after less than an hour because the reactor bed pressure drop, typically 10 to 12 in. of water, had steadily decreased. After 40 minutes of operation, the bed dP had dropped to 6 in., and the bed temperature had climbed from $1500^{\circ}$ to $1670^{\circ} \mathrm{F}$, because of the loss of bed material. Test KR2-2195 was operated at the same initial conditions, but with a lower velocity to try to maintain bed inventory. In less than an hour, the bed $\mathrm{dP}$ went from 10 to 5 in. of water, and the test was terminated.

Tables 5-4 and 5-5 show the average operating conditions and emissions, respectively, for each of the bench-scale tests. The values are averaged over the steady-state period in each test, so in some cases the test duration is very short. The averages and standard deviations for all of the points collected on the data acquisition system are shown for each test in Appendix A.

\subsubsection{Agglomeration and Deposition Tendencies}

Table 5-2 includes a column for results, giving a brief description of the overall outcome of the test. The results ranged from defluidization in less than an hour, to defluidization in 2 to 10 hours, to a full 16-hour test with no defluidization. Defluidization of the bed was evidenced by a sudden increase in temperature at the top of the bed (typically 9 in. or 11 in. above the bottom of the reactor). A camera aim through a sight port located at the top of the reactor allowed for visual monitoring of the bed. During normal operation, the bubbling action of the bed could clearly be seen, while a defluidized bed showed a bright glow with no movement.

While no clear effect of either temperature or excess air can be concluded, temperature and excess air appear to work together to create favorable conditions for defluidization. At a bed temperature of $1500^{\circ} \mathrm{F}$, for example, the high-excess air tests (Tests 7 and 10) defluidized in an hour or less; the low-excess air test (Test 5) did not defluidize at all. At $1700^{\circ} \mathrm{F}$, the reverse was true: the low-excess air test (Test 4) defluidized in 3 hours. The high-excess air test at high temperature was run twice, once each with Fuels KR1 and KR2. Test 6 , with the slightly lower-sodium fuel, did not defluidize in 8.5 hours of operation; Test 15 , with slightly higher sodium, defluidized in about 3 hours. This is still significantly longer than the highexcess air test at low temperature. Tests 3 and 14 , at $1600^{\circ} \mathrm{F}$ and medium excess air, also showed the effect of sodium content. The KR1 fuel ran for 5 hours at these conditions before defluidization; the KR2 fuel defluidized in less than 2 hours.

The effect of $\mathrm{SO}_{2}$ addition on agglomeration potential was also affected by temperature. In Tests 16 and 17, $\mathrm{SO}_{2}$ was added to the fluidizing air just before the preheater. An analyzer at that point allowed for accurate control of the added $\mathrm{SO}_{2}$ to $2000 \mathrm{ppm}$. At $1700^{\circ} \mathrm{F}$ and $30 \%$ excess air, $\mathrm{SO}_{2}$ addition had no effect on the time to defluidization, with both Tests 15 and 16 running for about 3 hours. However, at $1500^{\circ} \mathrm{F}$, Test 17 ran for 6.3 hours, compared to 1 hour for Test 10 , without the $\mathrm{SO}_{2}$ addition. Apparently the added sulfur does a much better job of tying up sodium at the lower temperature. 
TABLE 5-4

Operating Conditions for Bench-Scale Tests

\begin{tabular}{|c|c|c|c|c|c|c|c|c|c|}
\hline $\begin{array}{l}\text { Test No.: } \\
\text { Start Time: } \\
\text { Stop Time: } \\
\text { Date: }\end{array}$ & $\begin{array}{r}\mathrm{KR} 1-0195 \\
0630 \\
2230 \\
1-9-95 \\
\end{array}$ & $\begin{array}{r}\text { KR1-0295 } \\
0925 \\
1349 \\
1-17-95 \\
\end{array}$ & $\begin{array}{r}\mathrm{KR} 1-0395 \\
0824 \\
1154 \\
1-19-95 \\
\end{array}$ & $\begin{array}{r}\text { KR1-0495 } \\
0731 \\
0929 \\
1-23-95 \\
\end{array}$ & $\begin{array}{r}\text { KR1-0595 } \\
0735 \\
2321 \\
1-25-95 \\
\end{array}$ & $\begin{array}{r}\text { KR1-0695 } \\
0836 \\
1519 \\
1-27-95 \\
\end{array}$ & $\begin{array}{r}\mathrm{KR} 2-0795 \\
0758 \\
0821 \\
2-1-95 \\
\end{array}$ & $\begin{array}{r}\text { KR2-1095 } \\
0854 \\
1002 \\
3-14-95 \\
\end{array}$ & $\begin{array}{r}\text { KR2-1295 } \\
0730 \\
2330 \\
3-23-95 \\
\end{array}$ \\
\hline Sorbent Feed Rate, lb/hr & 0 & 0 & 0 & 0 & 0 & 0 & 0 & 0 & 0 \\
\hline Additive Feed Rate & 0 & 0 & 0 & 0 & 0 & 0 & 0 & 0 & 0.22 \\
\hline Reactor $\mathrm{dP}$, in. $\mathrm{H}_{2} \mathrm{O}$ & 14.9 & 11.4 & 9.34 & 10.2 & 8.2 & 8.3 & 9.3 & 8.3 & 11.5 \\
\hline Cyclone $\mathrm{dP}$, in. $\mathrm{H}_{2} \mathrm{O}$ & 1.7 & 4.0 & 2.6 & 2.4 & 3.3 & 7.6 & 10.9 & 2.0 & 2.1 \\
\hline \multicolumn{10}{|l|}{ Fhuidizing Gas, scfm } \\
\hline Air & 4.13 & 6.34 & 3.25 & 3.26 & 2.72 & 4.4 & 3.54 & 3.4 & 3.72 \\
\hline Nitrogen & 0 & 0 & 0.46 & 0 & 1.14 & 0 & 0 & 0 & 0 \\
\hline Total & 4.13 & 6.34 & 3.71 & 3.26 & 3.86 & 4.4 & 3.54 & 3.4 & 3.72 \\
\hline Excess Air, \% & 29.15 & 27.47 & 17.64 & 3.27 & 2.99 & 29.35 & 32.9 & 28.99 & 29.69 \\
\hline FG SGV', fu/sec & 6.37 & 11.07 & 6.01 & 5.63 & 5.90 & 7.54 & 5.67 & 5.33 & 5.85 \\
\hline \multicolumn{10}{|l|}{ Reactor Temperatures, ${ }^{\circ} \mathrm{F}$} \\
\hline Preheater Exit & 333 & 972 & 451 & 488 & 410 & 545 & 555 & 457 & 484 \\
\hline 0.25 in. & 1462 & 1710 & 1504 & 1608 & 1509 & 1550 & 1541 & 1494 & 1431 \\
\hline $1.75 \mathrm{in}$ & 1516 & 1720 & 1537 & 1667 & 1422 & 1665 & 1472 & 1402 & 1491 \\
\hline $3.5 \mathrm{in}$. & 1512 & 1730 & 1576 & 1689 & 1458 & 1712 & 1483 & 1415 & 1511 \\
\hline $5.0 \mathrm{in.}$ & 1501 & 1703 & 1584 & 1699 & 1496 & 1725 & 1483 & 1423 & 1517 \\
\hline $7.0 \mathrm{in.}$ & 1481 & 1690 & 1604 & 1708 & 1554 & 1727 & 1482 & 1516 & 1529 \\
\hline 9.0 in. & 1411 & 1679 & 1647 & 1703 & 1505 & 1699 & 1528 & 1664 & 1582 \\
\hline $11.0 \mathrm{in.}$ & 1441 & 1681 & 1680 & 1728 & 1622 & 1685 & 1621 & 1639 & 1645 \\
\hline 15.0 in. & 1524 & 1702 & 1657 & 1760 & 1517 & 1720 & 1629 & 1648 & 1628 \\
\hline 23.0 in. & 1557 & 1723 & 1629 & 1692 & 1521 & 1726 & 1621 & 1594 & 1575 \\
\hline 31.0 in. & 1514 & 1666 & 1575 & 1643 & 1491 & 1707 & 1580 & 1527 & 1495 \\
\hline $43.25 \mathrm{in}$. & 1494 & 1625 & 1542 & 1554 & 1505 & 1694 & 1506 & 1523 & 1501 \\
\hline Average & 1492 & 1694 & 1594 & 1677 & 1509 & 1692 & 1541 & 1531 & 1537 \\
\hline Cyclone Exit & 883 & 1035 & 799 & 807 & 811 & 897 & 840 & 799 & 876 \\
\hline
\end{tabular}

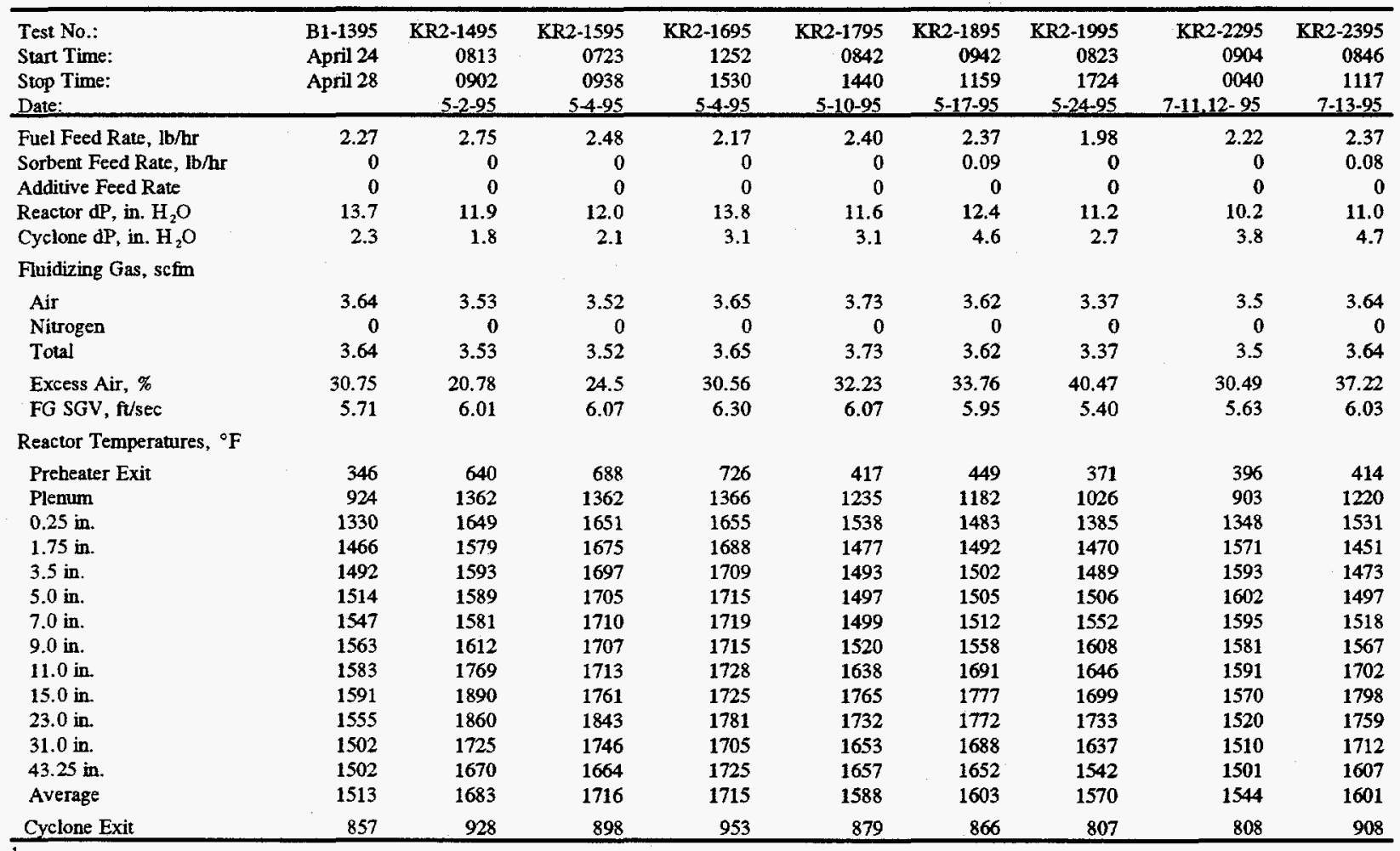

${ }^{1}$ Flue gas superficial gas velocity. 
TABLE 5-5

Emissions for Bench-Scale Tests

\begin{tabular}{|c|c|c|c|c|c|c|c|c|c|}
\hline & KR1_0195 & KR1-0295 & KR1-0395 & KR1-0495 & KR1-0595 & KR1-0695 & KR2-0795 & KR2-1095 & KR2-1295 \\
\hline $\begin{array}{l}\mathrm{O}_{2}, \% \\
\text { Excess Air, \% }\end{array}$ & $\begin{array}{r}4.71 \\
28.44\end{array}$ & $\begin{array}{r}4.58 \\
27.19\end{array}$ & $\begin{array}{r}3.24 \\
17.08\end{array}$ & $\begin{array}{l}0.86 \\
2.99\end{array}$ & $\begin{array}{l}0.66 \\
2.09\end{array}$ & $\begin{array}{r}4.81 \\
29.21\end{array}$ & $\begin{array}{r}5.19 \\
32.20\end{array}$ & 4.75 & 4.85 \\
\hline $\begin{array}{l}\text { Co Content, ppm } \\
\text { co Content }{ }^{2}, \text { ppm } \\
\text { Co Emission, lb/MMBu } \\
\text { co Content }{ }^{2} \text {, corrected ppm }\end{array}$ & $\begin{array}{r}425 \\
470 \\
0.392 \\
470\end{array}$ & $\begin{array}{r}251 \\
275 \\
0.241 \\
275\end{array}$ & $\begin{array}{r}966 \\
979 \\
0.970 \\
1118\end{array}$ & $\begin{array}{r}4800 \\
4290 \\
3.657 \\
4290\end{array}$ & $\begin{array}{r}3900 \\
3451 \\
4.116 \\
4898\end{array}$ & $\begin{array}{r}80 \\
89 \\
0.076 \\
89\end{array}$ & $\begin{array}{r}162 \\
184 \\
0.157 \\
184\end{array}$ & 52 & 158 \\
\hline $\begin{array}{l}\mathrm{CO}_{2} \text { Content, } \% \\
\mathrm{CO}_{2} \text { Content } t^{1}, \% \\
\mathrm{CO}_{2} \text { Content }{ }^{2}, \text { corrected } \%\end{array}$ & $\begin{array}{l}15.0 \\
16.6 \\
16.6\end{array}$ & $\begin{array}{l}14.5 \\
15.9 \\
15.9\end{array}$ & $\begin{array}{l}13.8 \\
14.0 \\
15.9\end{array}$ & $\begin{array}{l}17.8 \\
15.9 \\
15.9\end{array}$ & $\begin{array}{l}12.8 \\
11.3 \\
16.1\end{array}$ & $\begin{array}{l}14.7 \\
16.3 \\
16.3\end{array}$ & $\begin{array}{l}14.2 \\
16.2 \\
16.2\end{array}$ & 14.8 & 13.9 \\
\hline $\begin{array}{l}\mathrm{NO}_{\mathrm{x}} \text { Content, ppm } \\
\mathrm{NO}_{\mathrm{x}} \text { Content }{ }^{1}, \mathrm{ppm} \\
\mathrm{NO}_{\mathrm{x}} \text { Emission, lb/MMBu } \\
\mathrm{NO}_{\mathrm{x}} \text { Content }{ }^{2} \text {, corrected ppm }\end{array}$ & $\begin{array}{r}359 \\
397 \\
0.545 \\
397\end{array}$ & $\begin{array}{r}377 \\
413 \\
0.595 \\
413\end{array}$ & $\begin{array}{r}364 \\
369 \\
0.601 \\
421\end{array}$ & $\begin{array}{r}260 \\
232 \\
0.326 \\
232\end{array}$ & $\begin{array}{r}190 \\
168 \\
0.330 \\
239\end{array}$ & $\begin{array}{r}357 \\
397 \\
0.557 \\
397\end{array}$ & $\begin{array}{r}342 \\
389 \\
0.545 \\
389\end{array}$ & 328 & 311 \\
\hline $\begin{array}{l}\mathrm{N}_{2} \mathrm{O} \text { Content, ppm } \\
\mathrm{N}_{2} \mathrm{O} \text { Content }{ }^{1}, \mathrm{ppm} \\
\mathrm{N}_{2} \mathrm{O} \text { Emission, lb } \mathrm{MMBu} \\
\mathrm{N}_{2} \mathrm{O} \text { Content, corrected ppm }\end{array}$ & $\begin{array}{r}14 \\
15 \\
0.020 \\
15\end{array}$ & $\begin{array}{r}19 \\
21 \\
0.029 \\
21\end{array}$ & $\begin{array}{r}18 \\
18 \\
0.028 \\
21\end{array}$ & $\begin{array}{r}58 \\
52 \\
0.069 \\
52\end{array}$ & $\begin{array}{r}55 \\
49 \\
0.091 \\
69\end{array}$ & $\begin{array}{r}17 \\
19 \\
0.025 \\
19\end{array}$ & $\begin{array}{r}15 \\
17 \\
0.023 \\
17\end{array}$ & $\begin{array}{r}\text { NA } \\
0 \\
0.000 \\
0\end{array}$ & $\begin{array}{r}\text { NA } \\
0 \\
0.000 \\
0\end{array}$ \\
\hline $\begin{array}{l}\mathrm{SO}_{2} \text { Content, ppm } \\
\mathrm{SO}_{2} \text { Content }{ }^{1} \text { ppm } \\
\mathrm{SO}_{2} \text { Emission, lb/MMBu } \\
\mathrm{SO}_{2} \text { Retention, \% } \\
\mathrm{SO}_{2} \text { Content, corrected ppm }\end{array}$ & $\begin{array}{r}79 \\
87 \\
0.167 \\
87.1 \\
87\end{array}$ & $\begin{array}{r}283 \\
310 \\
0.622 \\
52.0 \\
310\end{array}$ & $\begin{array}{r}238 \\
241 \\
0.547 \\
57.8 \\
275\end{array}$ & $\begin{array}{r}405 \\
362 \\
0.706 \\
45.5 \\
362\end{array}$ & $\begin{array}{r}242 \\
214 \\
0.584 \\
54.9 \\
304\end{array}$ & $\begin{array}{r}244 \\
271 \\
0.530 \\
59.0 \\
271\end{array}$ & $\begin{array}{r}269 \\
306 \\
0.597 \\
67.0 \\
306\end{array}$ & 222 & 448 \\
\hline $\begin{array}{l}\mathrm{Ca} / \mathrm{S} \text { Ratio } \\
\mathrm{Ca} \text { Utulization }\end{array}$ & $\begin{array}{l}1.53 \\
56.9 \\
\end{array}$ & $\begin{array}{l}1.53 \\
34.0 \\
\end{array}$ & $\begin{array}{l}1.53 \\
37.7 \\
\end{array}$ & $\begin{array}{l}1.53 \\
29.7 \\
\end{array}$ & $\begin{array}{l}1.53 \\
35.8 \\
\end{array}$ & $\begin{array}{l}1.53 \\
38.6 \\
\end{array}$ & $\begin{array}{l}0.99 \\
67.4 \\
\end{array}$ & 0.99 & 0.99 \\
\hline
\end{tabular}

\begin{tabular}{|c|c|c|c|c|c|c|c|c|c|}
\hline & B1-1395 & KR2-1495 & KR2-1595 & KR2-1695 & KR2-1795 & KR2-1895 & KR2-1995 & KR2-2295 & KR2-2395 \\
\hline $\begin{array}{l}\mathrm{O}_{2}, \% \\
\text { Excess Air, \% }\end{array}$ & $\begin{array}{r}4.93 \\
30.26\end{array}$ & $\begin{array}{r}3.67 \\
20.50\end{array}$ & $\begin{array}{r}4.12 \\
23.93\end{array}$ & $\begin{array}{r}4.95 \\
29.80\end{array}$ & $\begin{array}{r}5.11 \\
31.68\end{array}$ & $\begin{array}{r}4.43 \\
26.13\end{array}$ & $\begin{array}{r}6.04 \\
39.40\end{array}$ & $\begin{array}{r}4.89 \\
29.78\end{array}$ & $\begin{array}{r}5.63 \\
36.75\end{array}$ \\
\hline $\begin{array}{l}\text { CO Content, ppm } \\
\text { CO Content }{ }^{1}, \mathrm{ppm} \\
\text { CO Emission, } \mathrm{lb} / \mathrm{MMBtu} \\
\text { CO Content, corrected ppm }\end{array}$ & $\begin{array}{r}71 \\
80 \\
0.069 \\
80\end{array}$ & $\begin{array}{r}605 \\
628 \\
0.545 \\
628\end{array}$ & $\begin{array}{r}434 \\
463 \\
0.386 \\
463\end{array}$ & $\begin{array}{r}227 \\
255 \\
0.231 \\
255\end{array}$ & $\begin{array}{r}118 \\
134 \\
0.112 \\
134\end{array}$ & $\begin{array}{r}135 \\
147 \\
0.127 \\
147\end{array}$ & $\begin{array}{r}38 \\
46 \\
0.040 \\
46\end{array}$ & $\begin{array}{r}738 \\
825 \\
0.679 \\
825\end{array}$ & $\begin{array}{r}45 \\
53 \\
0.041 \\
53\end{array}$ \\
\hline $\begin{array}{l}\mathrm{CO}_{2} \text { Content, } \% \\
\mathrm{CO}_{2} \text { Content }, \% \\
\mathrm{CO}_{2} \text { Content, corrected } \%\end{array}$ & $\begin{array}{l}14.7 \\
16.5 \\
16.5\end{array}$ & $\begin{array}{l}15.2 \\
15.8 \\
15.8\end{array}$ & $\begin{array}{l}15.5 \\
16.5 \\
16.5\end{array}$ & $\begin{array}{l}13.5 \\
15.2 \\
15.2\end{array}$ & $\begin{array}{l}14.5 \\
16.4 \\
16.4\end{array}$ & $\begin{array}{l}14.7 \\
15.9 \\
15.9\end{array}$ & $\begin{array}{l}13.0 \\
15.7 \\
15.7\end{array}$ & $\begin{array}{l}14.9 \\
16.7 \\
16.7\end{array}$ & $\begin{array}{l}15.0 \\
17.6 \\
17.6\end{array}$ \\
\hline $\begin{array}{l}\mathrm{NO}_{2} \text { Content, ppm } \\
\mathrm{NO}_{x} \text { Content }{ }^{1}, \mathrm{ppm} \\
\mathrm{NO}_{2} \text { Emission, lb/MMBa } \\
\mathrm{NO}_{2} \text { Content, corrected ppm }\end{array}$ & $\begin{array}{r}355 \\
398 \\
0.570 \\
398\end{array}$ & $\begin{array}{r}377 \\
392 \\
0.559 \\
392\end{array}$ & $\begin{array}{r}372 \\
397 \\
0.544 \\
397\end{array}$ & $\begin{array}{r}403 \\
452 \\
0.674 \\
452\end{array}$ & $\begin{array}{r}406 \\
460 \\
0.634 \\
460\end{array}$ & $\begin{array}{r}414 \\
450 \\
0.639 \\
450\end{array}$ & $\begin{array}{r}444 \\
534 \\
0.772 \\
534\end{array}$ & $\begin{array}{r}456 \\
509 \\
0.690 \\
509\end{array}$ & $\begin{array}{r}521 \\
610 \\
0.785 \\
610\end{array}$ \\
\hline $\begin{array}{l}\mathrm{N}_{2} \mathrm{O} \text { Content, ppm } \\
\mathrm{N}_{2} \mathrm{O} \text { Content }{ }^{1}, \mathrm{ppm} \\
\mathrm{N}_{2} \mathrm{O} \text { Emission, lb/MMBtu } \\
\mathrm{N}_{2} \mathrm{O} \text { Content, corrected ppm }\end{array}$ & $\begin{array}{r}\text { NA } \\
0 \\
0.000 \\
0\end{array}$ & $\begin{array}{r}\text { NA } \\
0 \\
0.000 \\
0\end{array}$ & $\begin{array}{r}\text { NA } \\
0 \\
0.000 \\
0\end{array}$ & $\begin{array}{r}\text { NA } \\
0 \\
0.000 \\
0\end{array}$ & $\begin{array}{r}\text { NA } \\
0 \\
0.000 \\
0\end{array}$ & $\begin{array}{r}\text { NA } \\
0 \\
0.000 \\
0\end{array}$ & $\begin{array}{r}\text { NA } \\
0 \\
0.000 \\
0\end{array}$ & $\begin{array}{r}\mathrm{NA} \\
0 \\
0.000 \\
0\end{array}$ & $\begin{array}{r}\text { NA } \\
0 \\
0.000 \\
0\end{array}$ \\
\hline $\begin{array}{l}\mathrm{SO}_{2} \text { Content, ppm } \\
\mathrm{SO}_{2} \text { Content }{ }^{1}, \mathrm{ppm} \\
\mathrm{SO}_{2} \text { Emission, lb/MMBtu } \\
\mathrm{SO}_{2} \text { Retention }{ }^{2}, \% \\
\mathrm{SO}_{2} \text { Content, corrected ppm }\end{array}$ & $\begin{array}{r}1017 \\
1139 \\
2.271 \\
66.2 \\
1139\end{array}$ & $\begin{array}{r}584 \\
607 \\
1.204 \\
33.5 \\
607\end{array}$ & $\begin{array}{r}111 \\
118 \\
0.226 \\
87.5 \\
118\end{array}$ & $\begin{array}{r}1833 \\
2056 \\
4.264 \\
29.4 \\
2056\end{array}$ & $\begin{array}{r}1800 \\
2039 \\
3.911 \\
35.6 \\
2039\end{array}$ & $\begin{array}{r}280 \\
304 \\
0.601 \\
66.8 \\
304\end{array}$ & $\begin{array}{r}196 \\
236 \\
0.474 \\
73.8 \\
236\end{array}$ & $\begin{array}{r}12 \\
13 \\
0.025 \\
98.6 \\
13\end{array}$ & $\begin{array}{r}113 \\
132 \\
0.237 \\
86.9 \\
132\end{array}$ \\
\hline $\begin{array}{l}\mathrm{Ca} / \mathrm{S} \text { Ratio } \\
\mathrm{Ca} \text { Utilization }\end{array}$ & $\begin{array}{r}0.39 \\
172.0\end{array}$ & $\begin{array}{l}0.99 \\
33,7\end{array}$ & $\begin{array}{l}0.99 \\
88.0\end{array}$ & $\begin{array}{l}0.30 \\
98.5\end{array}$ & $\begin{array}{r}0.30 \\
120.4\end{array}$ & $\begin{array}{l}1.95 \\
34.2\end{array}$ & $\begin{array}{l}0.99 \\
74.2\end{array}$ & $\begin{array}{l}0.99 \\
99.1\end{array}$ & $\begin{array}{l}2.18 \\
39.8 \\
\end{array}$ \\
\hline
\end{tabular}

1 Corrected to $3 \% \mathrm{O}_{2}$.

2 Correct to $3 \% \mathrm{O}_{2}$ and nitrogen dilution.

Several additives were tested for their effect on agglomeration potential. These tests were all performed at nominal conditions of $1500^{\circ} \mathrm{F}$ and $30 \%$ excess air. Kaolin, an aluminosilicate used as an alkali getter, was added to the coal for Tests KR2-1195 and KR2-1295. In the first test, the kaolin was added at the rate of 2.9 grams of kaolin/100 grams of coal. This represents 
the same kaolin-to-ash ratio used for alkali-gettering work under another program at the EERC. The operating conditions were unsteady through the test, with the excess air fluctuating from $30 \%$ to $60 \%$, and the Zone 2 temperature increasing continually. The reactor defluidized after 1.4 hours of operation.

For Test KR2-1295, the kaolin add rate was increased to 9.33 grams of kaolin/100 grams of coal, representing the same kaolin-to- $\mathrm{Na}_{2} \mathrm{O}$ ratio used in the alkali-gettering tests. KR2-1295 ran for the full 16 hours, with no agglomerates observed in the bed material.

Limestone addition, at a calcium-to-sulfur ratio of 2, provided some benefit in Test $\mathrm{KR} 2-2395$. This test ran for 3.1 hours at $1500^{\circ} \mathrm{F}$ and $30 \%$ excess air, three times as long as the same test without limestone addition.

Three different bed materials were also tested. As mentioned above, Tests 2095 and 2195, using dolomite as the bed material, were unsuccessful because the bed material elutriated from the reactor. Even when the velocity was lowered, bed inventory could not be maintained with the dolomite used.

Test KR2-1995 used gabbro as the bed material. This test ran 9.5 hours before defluidizing, compared to 1 hour at the same operating conditions with a silica sand bed. A limestone bed was even more successful, running the full 16 hours without defluidizing at all. The operating conditions for this test were $1600^{\circ} \mathrm{F}$ and $15 \%$ excess air. The same conditions with a sand bed defluidized in less than 2 hours.

Temperature distribution proved to be an effective predictor of defluidization. While the time to defluidization could not be determined, in virtually every test in which bed agglomeration forced a shutdown, the temperature measured at the top of the bed increased steadily for the duration of the test. Figures 5-4 and 5-5 show the difference in temperature distribution over time between a test that defluidized (KR2-1195) and one which did not (KR2-1295). Figure 5-4 also shows the characteristic temperature spike at the point of defluidization. Figure 5-6 shows the relationship between temperature distribution and defluidization for three tests with an average bed temperature of $1600^{\circ} \mathrm{F}$. The points shown represent the average of each temperature reading over the steady-state period of each test. Test 1495 , having very high freeboard temperatures relative to the bed, defluidized in 2 hours. Test 0395 had somewhat higher temperatures above the bed and defluidized in 5 hours. Test 2295, which ran 16 full hours without defluidizing, showed a very uniform temperature distribution throughout the reactor.

Visual examination of the bed material samples taken at 4-hour intervals during every test reveals a number of agglomeration mechanisms occurring. Every sample showed some evidence of coating on the bed material particles, with the coating generally becoming more uniform over time. Most of the tests exhibited some particle sticking by the end of the test, some as quickly as the first sample at 4 hours. Test KR1-0295 produced some egg-type agglomerates, in addition to particle bonding. The coating on the end-of-test bed material for Test KR1-0595 appeared fuzzy. 


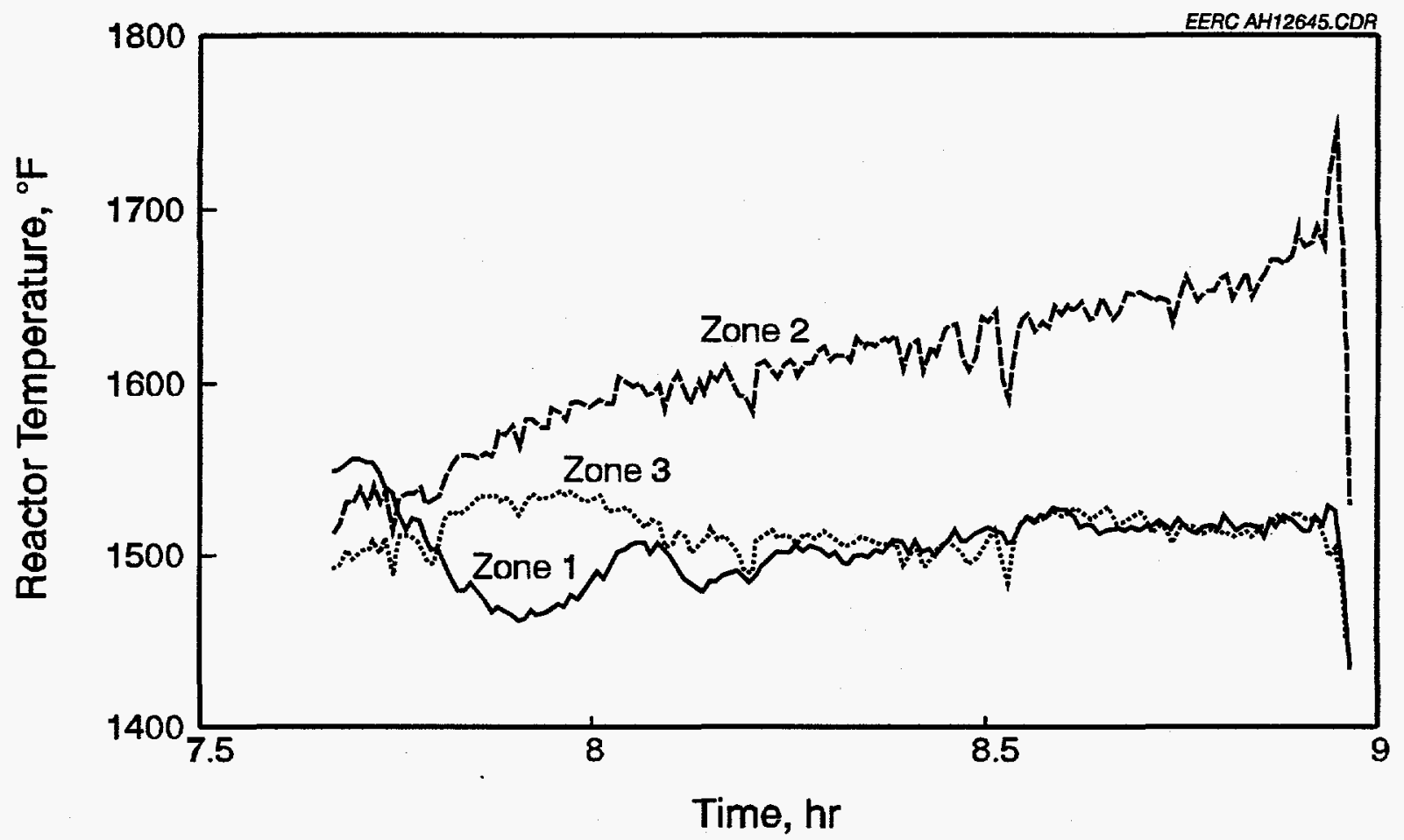

Figure 5-4. Temperature distribution over time for Test KR2-1195.

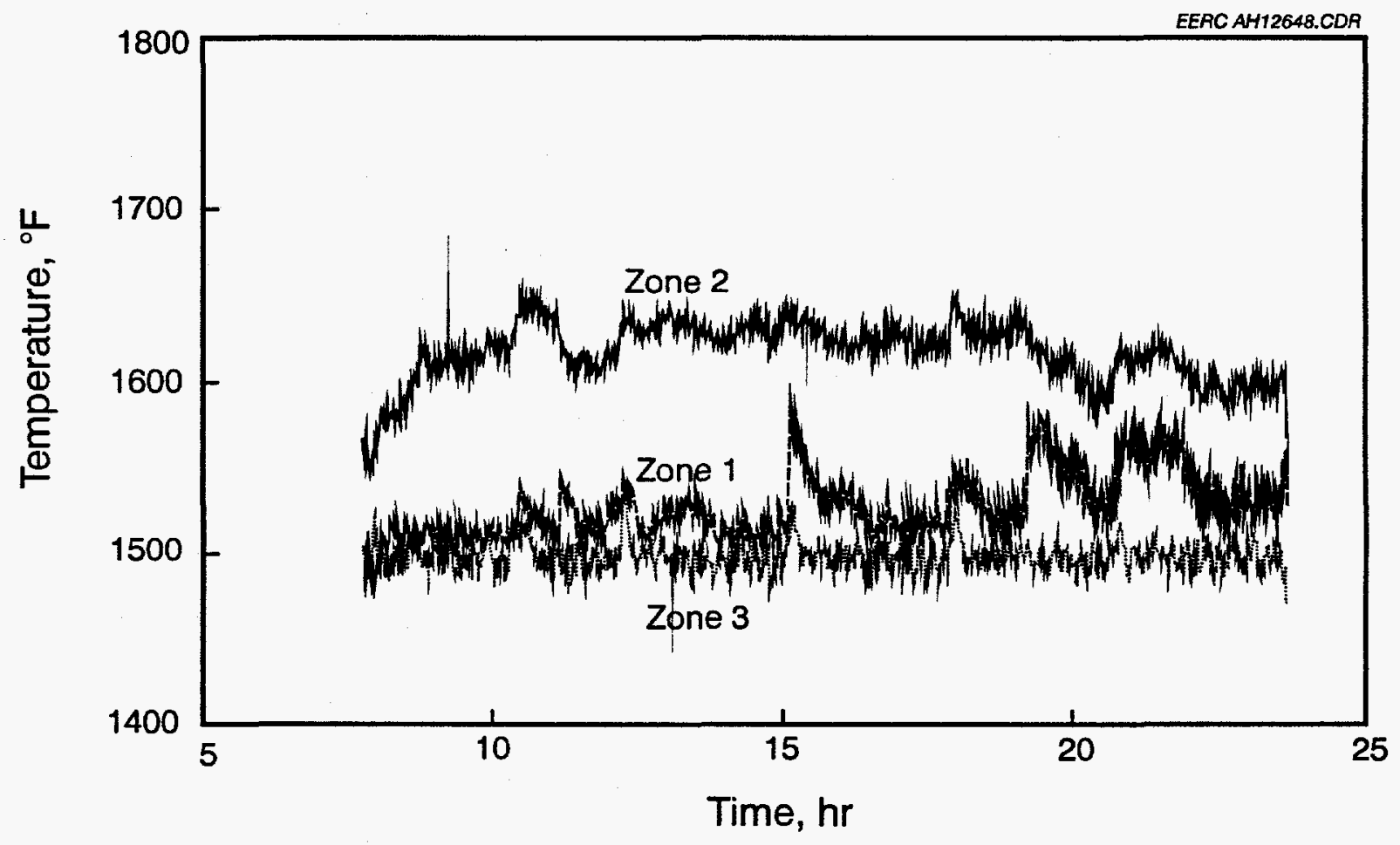

Figure 5-5. Temperature distribution over time for Test KR2-1295. 


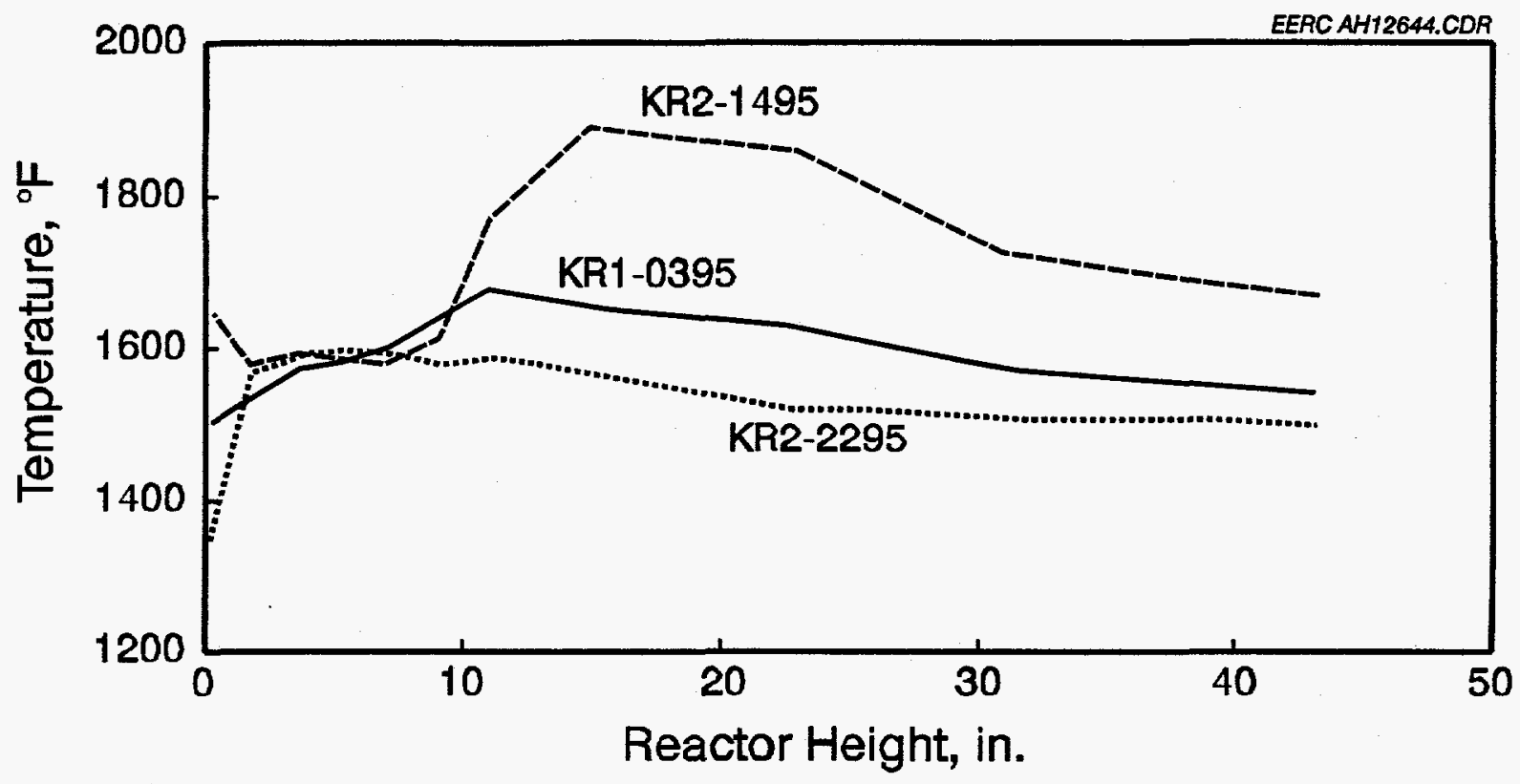

Figure 5-6. Temperature distribution for three bench-scale tests.

\subsubsection{Bulk Chemistry}

Figures 5-7 through 5-11 show the changes in bed chemistry over time for the tests that did not defluidize. In each case, the levels of $\mathrm{SiO}_{2}$ decreased, while the concentrations of $\mathrm{CaO}$, $\mathrm{Na}_{2} \mathrm{O}$, and $\mathrm{SO}_{3}$ increased as the start-up sand was replaced by ash. Figure 5-7 shows the bed chemistry for Test KR1-0195, the first low-temperature, high-excess air test. The sample taken at 4 hours reflects the high $\mathrm{CaO}$ content of the washed sand start-up material. This test had much higher levels of $\mathrm{SO}_{3}$ than the other 4 tests, which is consistent with the high sulfur retention observed during this test. The most rapid buildup of sodium in the bed occurred during Test KR1-0695, the repeated high-temperature, high-excess air test (Figure 5-9), followed by the low-temperature, high-excess air test (KR1-0195) shown in Figure 5-7. Tests KR1-0295 and KR2-2295 showed steady change over each 4-hour period (Figures 5-8 and 5-11), while Tests KR1-0295 and KR1-0595 both showed a more dramatic change in bed chemistry after 8 and 12 hours, respectively.

Test B1-1395 was a long-term test, using a relatively low-sodium (3.4\% in the ash) North Dakota lignite. The purpose of the test was to see how long this fuel could run before defluidization took place; however, the test was terminated after 113 hours without defluidizing. Figure 5-12 shows the composition of bed material samples collected every 12 hours during this test. The figure shows that the system had reached a chemical equilibrium by about 80 hours. This fuel contained more sulfur than the other fuels used for agglomeration tests ( $2.4 \%$ for this test compared to $0.7 \%$ for the others), which may account for the lack of agglomeration. The sulfur from the coal ties up the sodium in the bed, limiting its potential to cause agglomeration problems. The bench-scale tests with $\mathrm{SO}_{2}$ addition showed the same tendency. 


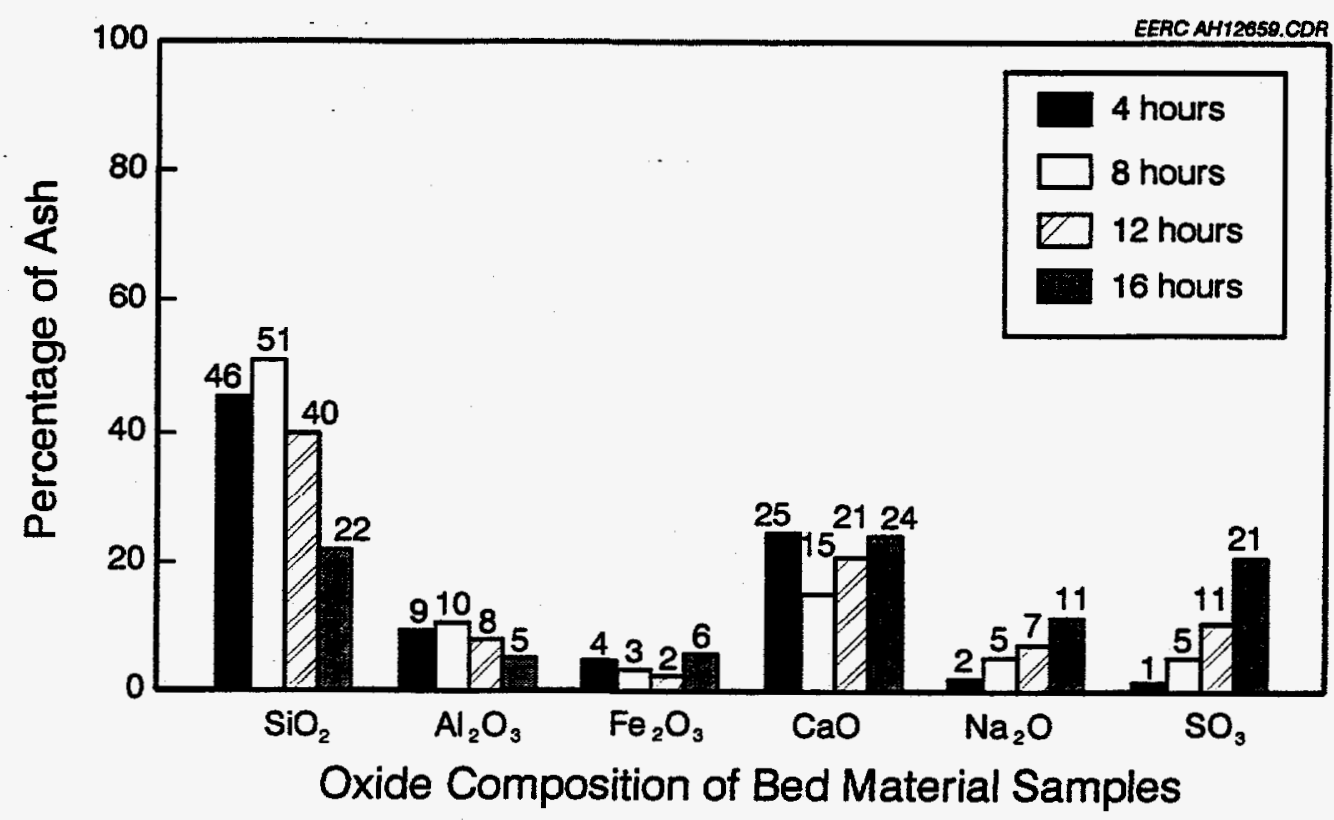

Figure 5-7. Chemical composition of bed material over time for Test KR1-0195.

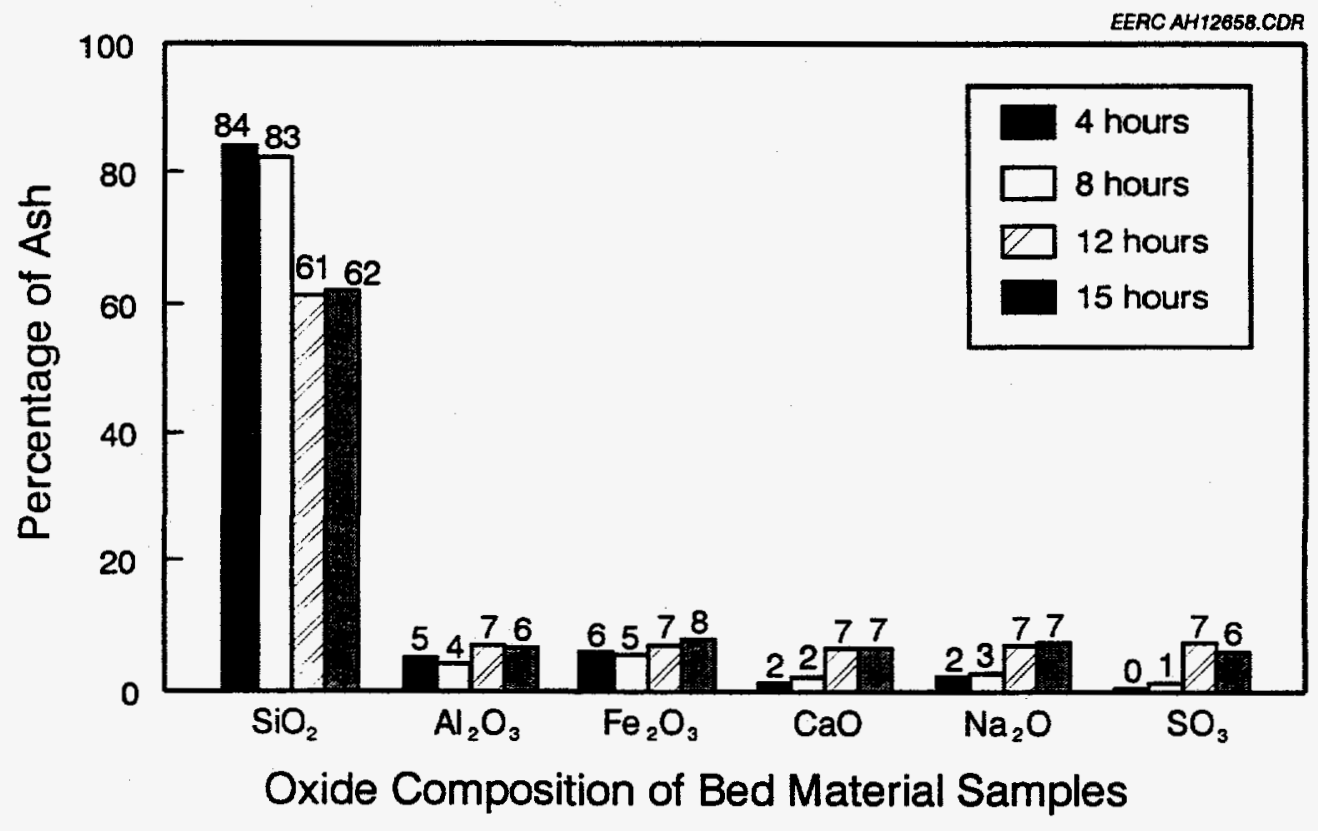

Figure 5-8. Chemical composition of bed material over time for Test KR1-0295. 


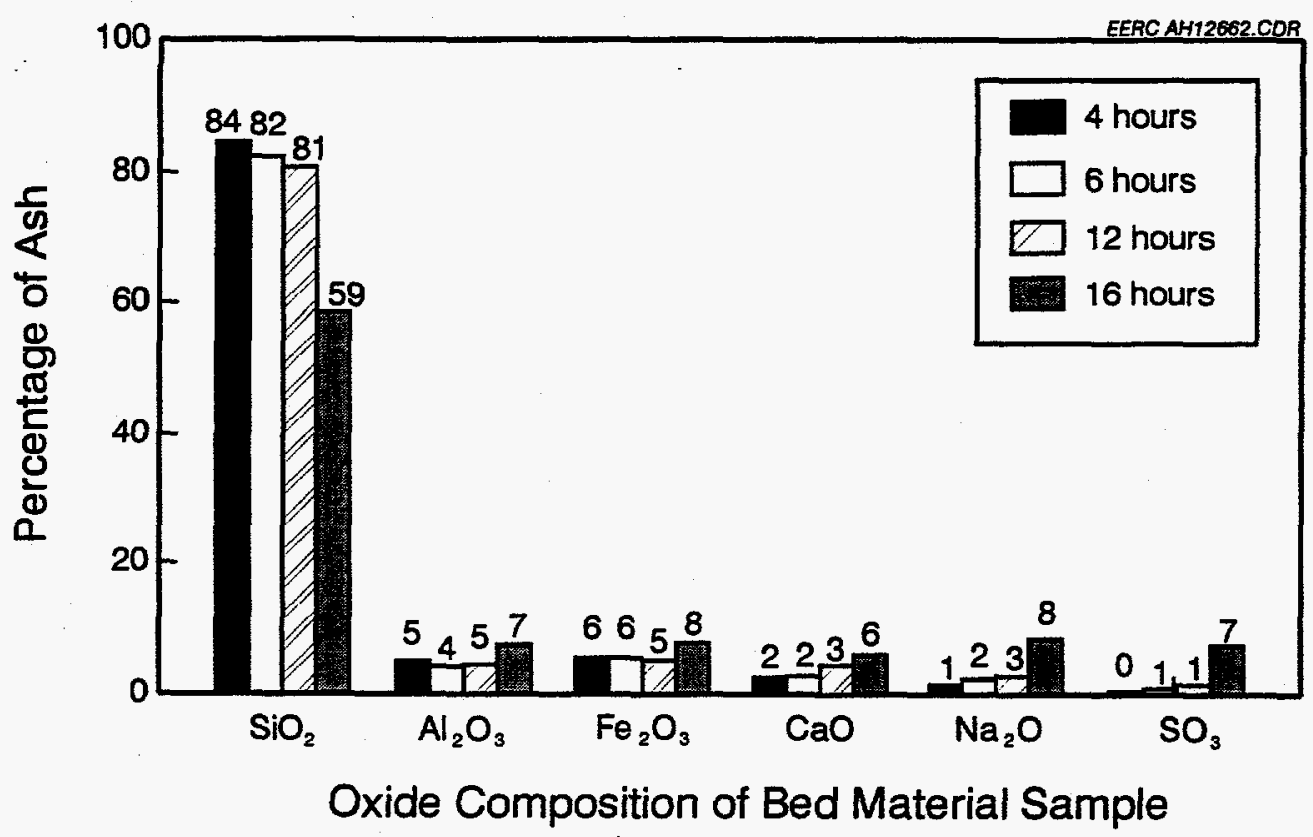

Figure 5-9. Chemical composition of bed material over time for Test KR1-0595.

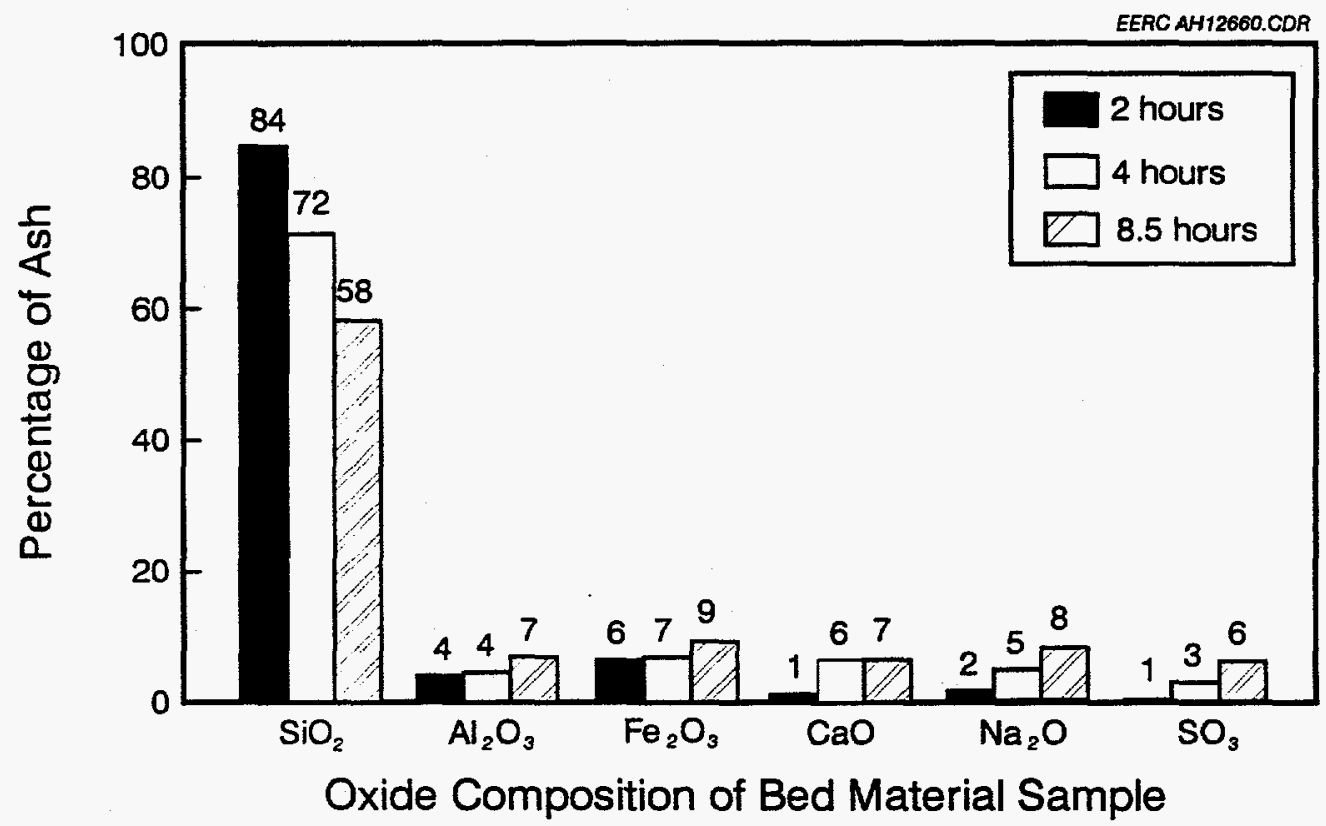

Figure 5-10. Chemical composition of bed material over time for Test KR1-0695. 


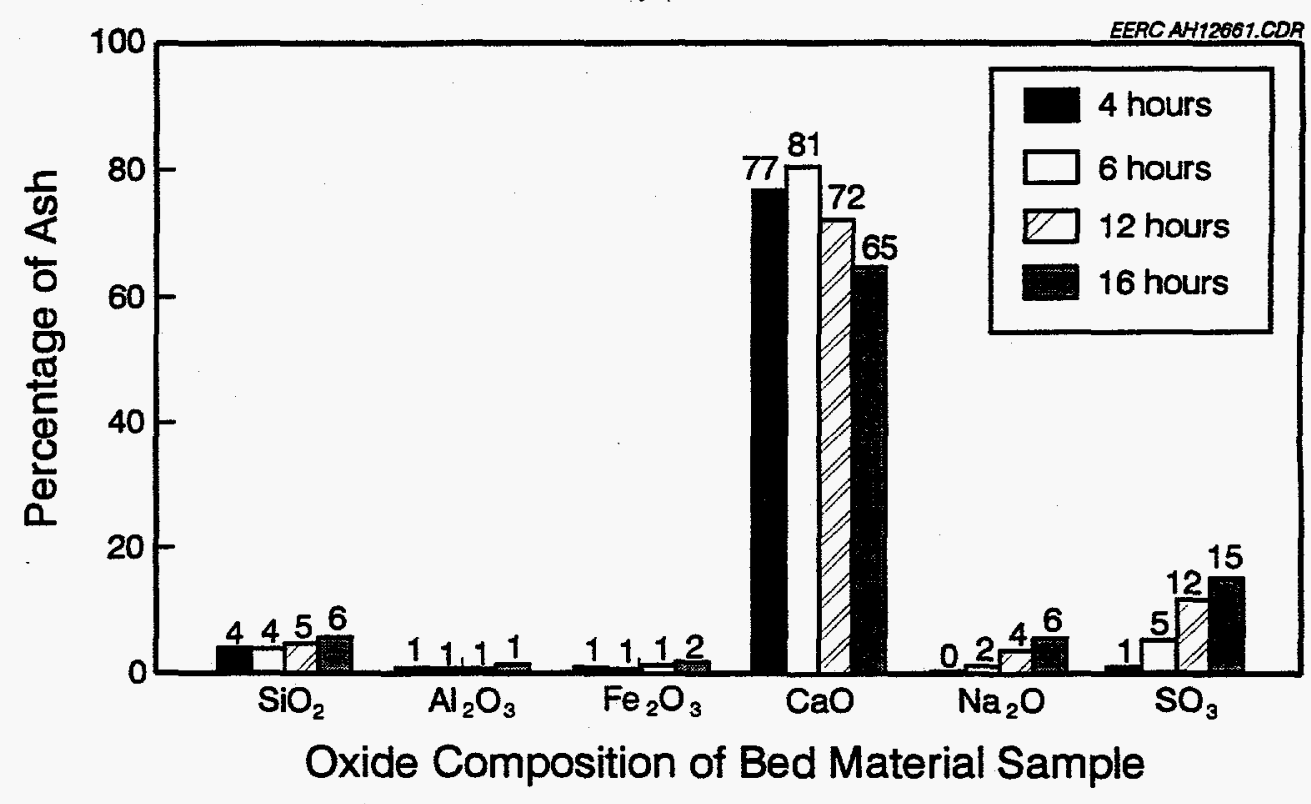

Figure 5-11. Chemical composition of bed material over time for Test KR2-2295.

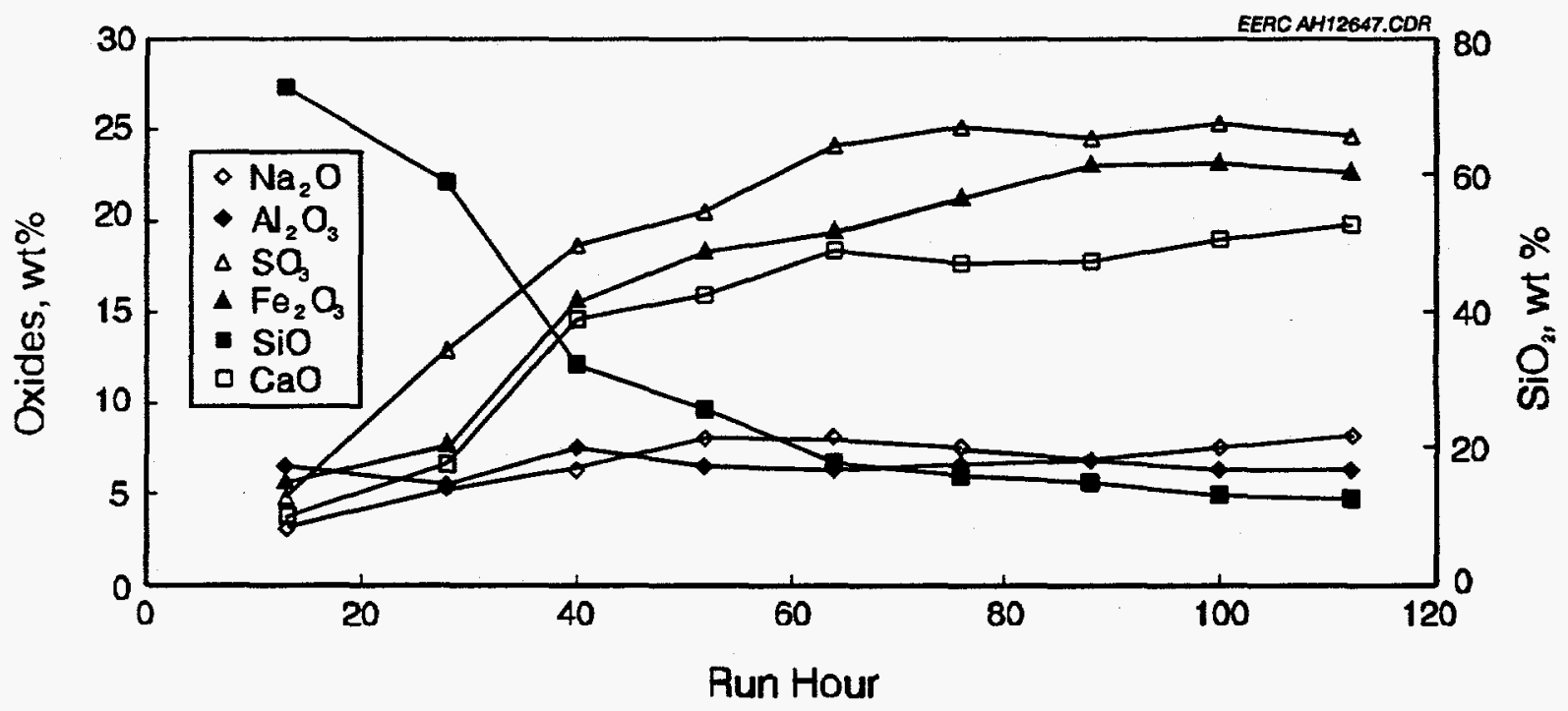

Figure 5-12. Chemical composition of bed material over time for Test B1-1395. 


\subsubsection{Morphology}

Several of the samples collected from bench-scale tests were examined using the electron microscope to determine the morphological structure of the materials. These samples are of four types: bed material collected during operation, agglomerates formed during a test that did not defluidized, agglomerates that caused defluidization and shutdown, and deposits.

The results of SEM examination of the bed material sample collected at the end of Test KR2-0595 are shown in Table 5-6, along with the bulk analysis for the same sample. The data show the coating to be rich in $\mathrm{CaO}, \mathrm{SO}_{3}, \mathrm{Na}_{2} \mathrm{O}, \mathrm{MgO}$, and $\mathrm{Al}_{2} \mathrm{O}_{3}$ compared to the bulk bed material.

The addition of kaolin with coal results in a much different bed chemistry after 16 hours, as the start-up sand is replaced by the aluminosilicate additive. Table 5-7 compares several SEM point analyses with the bulk sample. The bulk analysis confirms that the silica sand bed has been replaced by a bed of kaolin. The outer edge of the coating is composed of two distinct layers, shown by the vast difference between Points 1 and 2. The inner coating is more uniform and similar to the particle itself, with higher concentrations of iron and sodium. The interior of the bed particle is predominantly aluminosilicate. Sodium is very high at the coating-particle interface (Point 6) and decreases further into the particle (Points 7 and 8 ). The line scan for this sample, Figure 5-13, reinforces the lack of a distinct interface between the particle and the coating, suggesting an interaction between the kaolin particle and the coating. This indistinct region has a relatively high portion of sodium, especially on the right-hand side of the particle, indicating the sodium has migrated into the particle, as it did in the Black Dog sample and confirming the effect shown in Table 5-7.

Limestone was used as the starting bed material in Test KR2-2295. This test ran for 16 hours without defluidizing. After 4 hours, the bed material had virtually no coating;

TABLE 5-6

Analyses of Bed Material for Test KR1-0595

\begin{tabular}{lccccccc}
\hline Oxides, \% & $\begin{array}{c}\text { Coating } \\
\text { Point 4 }\end{array}$ & $\begin{array}{c}\text { Coating } \\
\text { Point 5 }\end{array}$ & $\begin{array}{c}\text { Coating } \\
\text { Point 6 }\end{array}$ & $\begin{array}{c}\text { Coating } \\
\text { Point 7 }\end{array}$ & $\begin{array}{c}\text { Coating } \\
\text { Point 8 }\end{array}$ & $\begin{array}{c}\text { Coating } \\
\text { Point 9 }\end{array}$ & $\begin{array}{c}\text { Bulk } \\
\text { XRFA }\end{array}$ \\
\hline $\mathrm{SiO}_{2}$ & 0.3 & 0.7 & 0.2 & 0.7 & 0.9 & 1.2 & 58.6 \\
$\mathrm{Al}_{2} \mathrm{O}_{3}$ & 6.2 & 11.0 & 5.3 & 6.4 & 6.3 & 12.1 & 7.3 \\
$\mathrm{Fe}_{2} \mathrm{O}_{3}$ & 5.2 & 5.3 & 10.7 & 8.1 & 4.4 & 6.6 & 7.7 \\
$\mathrm{P}_{2} \mathrm{O}_{5}$ & 0.5 & 0.5 & 0.4 & 0.0 & 0.6 & 0.3 & 0.3 \\
$\mathrm{CaO}$ & 33.1 & 24.1 & 28.9 & 24.9 & 28.8 & 28.0 & 6.2 \\
$\mathrm{MgO}$ & 9.2 & 12.0 & 5.7 & 11.2 & 8.1 & 15.8 & 3.0 \\
$\mathrm{Na}_{2} \mathrm{O}$ & 8.6 & 13.9 & 9.4 & 8.0 & 15.8 & 7.9 & 8.2 \\
$\mathrm{~K}_{2} \mathrm{O}$ & 0.5 & 0.5 & 0.8 & 0.9 & 0.0 & 0.4 & 1.1 \\
$\mathrm{SO}_{3}$ & 36.3 & 31.9 & 38.2 & 39.9 & 35.2 & 27.7 & 7.4 \\
\hline
\end{tabular}


TABLE 5-7

Analyses of Bed Material for Test KR2-1295

\begin{tabular}{lccccccccc}
\hline $\begin{array}{l}\text { Oxides, } \\
\%\end{array}$ & $\begin{array}{c}\text { Outer } \\
\text { Coating, } \\
\text { Pt. 1 }\end{array}$ & $\begin{array}{c}\text { Outer } \\
\text { Coating, } \\
\text { Pt. 2 }\end{array}$ & $\begin{array}{c}\text { Inner } \\
\text { Coating, } \\
\text { Pt. 3 }\end{array}$ & $\begin{array}{c}\text { Inner } \\
\text { Coating, } \\
\text { Pt. 4 }\end{array}$ & $\begin{array}{c}\text { Inner } \\
\text { Coating, } \\
\text { Pt. 5 }\end{array}$ & $\begin{array}{c}\text { Kaolin } \\
\text { Particle, } \\
\text { Pt. 6 }\end{array}$ & $\begin{array}{c}\text { Kaolin } \\
\text { Particle, } \\
\text { Pt. 7 }\end{array}$ & $\begin{array}{c}\text { Kaolin } \\
\text { Particle, } \\
\text { Pt. 8 }\end{array}$ & $\begin{array}{c}\text { Bulk } \\
\text { XRFA }\end{array}$ \\
\hline $\mathrm{SiO}_{2}$ & 42.9 & 1.9 & 42.7 & 32.3 & 37.3 & 41.5 & 45.8 & 53.3 & 58.0 \\
$\mathrm{Al}_{2} \mathrm{O}_{3}$ & 3.0 & 1.5 & 35.5 & 28.0 & 32.9 & 35.1 & 39.3 & 45.5 & 24.8 \\
$\mathrm{Fe}_{2} \mathrm{O}_{3}$ & 6.9 & 93.4 & 2.5 & 30.8 & 13.8 & 1.1 & 0.8 & 0.0 & 3.8 \\
$\mathrm{TiO}_{2}$ & 0.2 & 0.3 & 0.0 & 0.3 & 0.0 & 2.0 & 3.4 & 0.0 & 1.0 \\
$\mathrm{P}_{2} \mathrm{O}_{5}$ & 0.0 & 0.0 & 0.3 & 0.0 & 0.0 & 0.0 & 0.0 & 0.0 & 0.2 \\
$\mathrm{CaO}$ & 30.9 & 0.3 & 5.2 & 0.4 & 0.6 & 2.6 & 0.4 & 0.0 & 3.3 \\
$\mathrm{MgO}$ & 8.5 & 0.0 & 0.0 & 0.3 & 0.0 & 0.4 & 0.0 & 0.0 & 1.0 \\
$\mathrm{Na}_{2} \mathrm{O}$ & 4.1 & 1.2 & 12.9 & 6.3 & 12.6 & 15.0 & 8.9 & 0.3 & 4.0 \\
$\mathrm{~K}_{2} \mathrm{O}$ & 0.0 & 0.0 & 0.6 & 0.8 & 1.0 & 0.8 & 1.4 & 0.3 & 0.9 \\
$\mathrm{SO}_{3}$ & 3.5 & 1.5 & 0.2 & 0.9 & 2.0 & 1.6 & 0.0 & 0.6 & 3.0 \\
\hline
\end{tabular}

Note: Points 1 through 8 go from the outside edge to the interior of the particle.

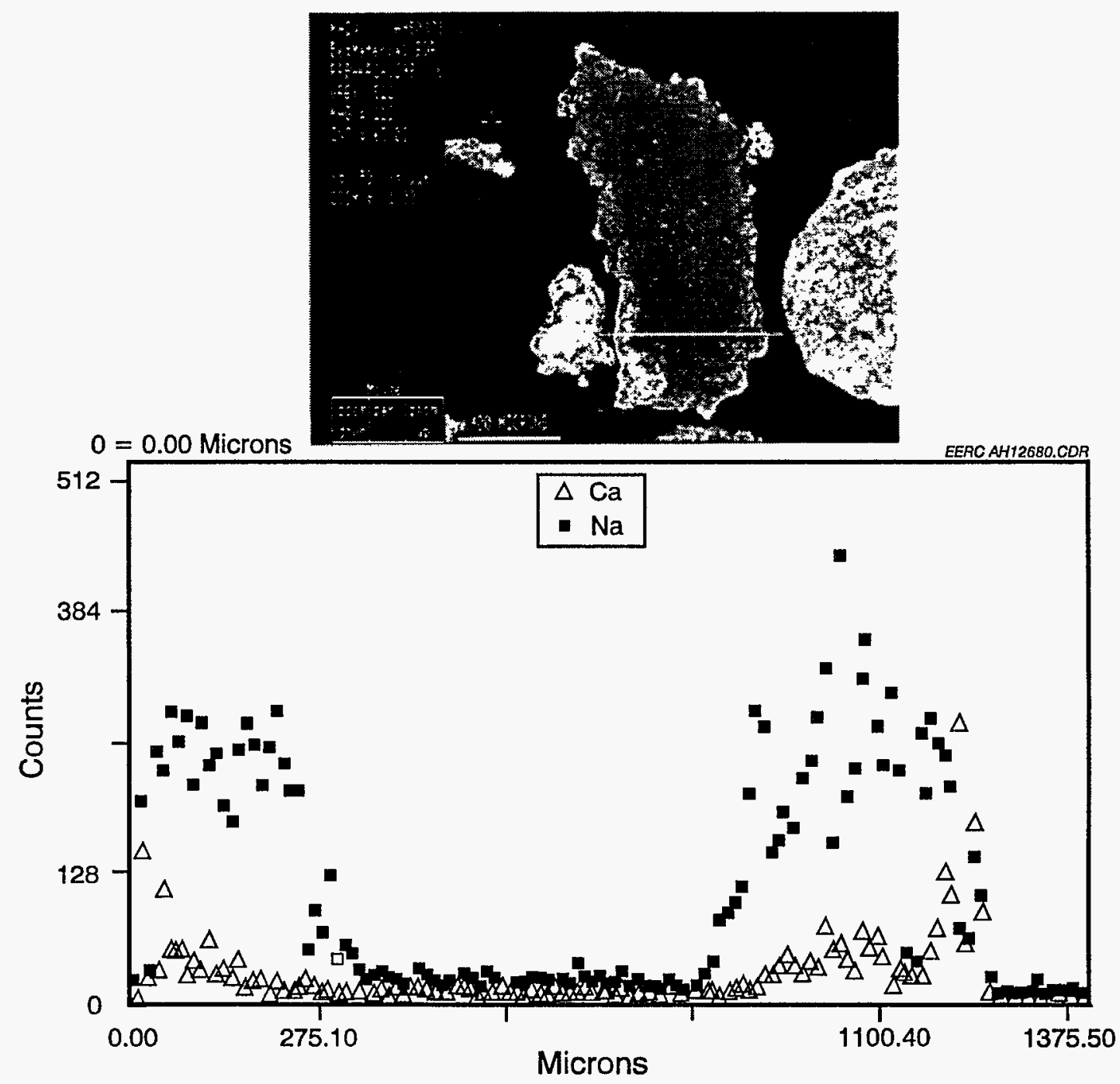

Figure 5-13. Line scan of coated bed particle from Test KR2-1295. 
line scan analysis of a particle showed only trace amounts of sodium and sulfur (Figure 5-14). However, the sample collected at the end of the test was well coated. Elemental mapping of several particles revealed the coating on the particles to consist of magnesium, aluminum, silica, and sulfur (Figure 5-15); sodium and sulfur were present throughout the bed particles. A line scan of one of the particles pictured in the elemental map shows the migration of sodium and sulfur into the particle (Figure 5-16).

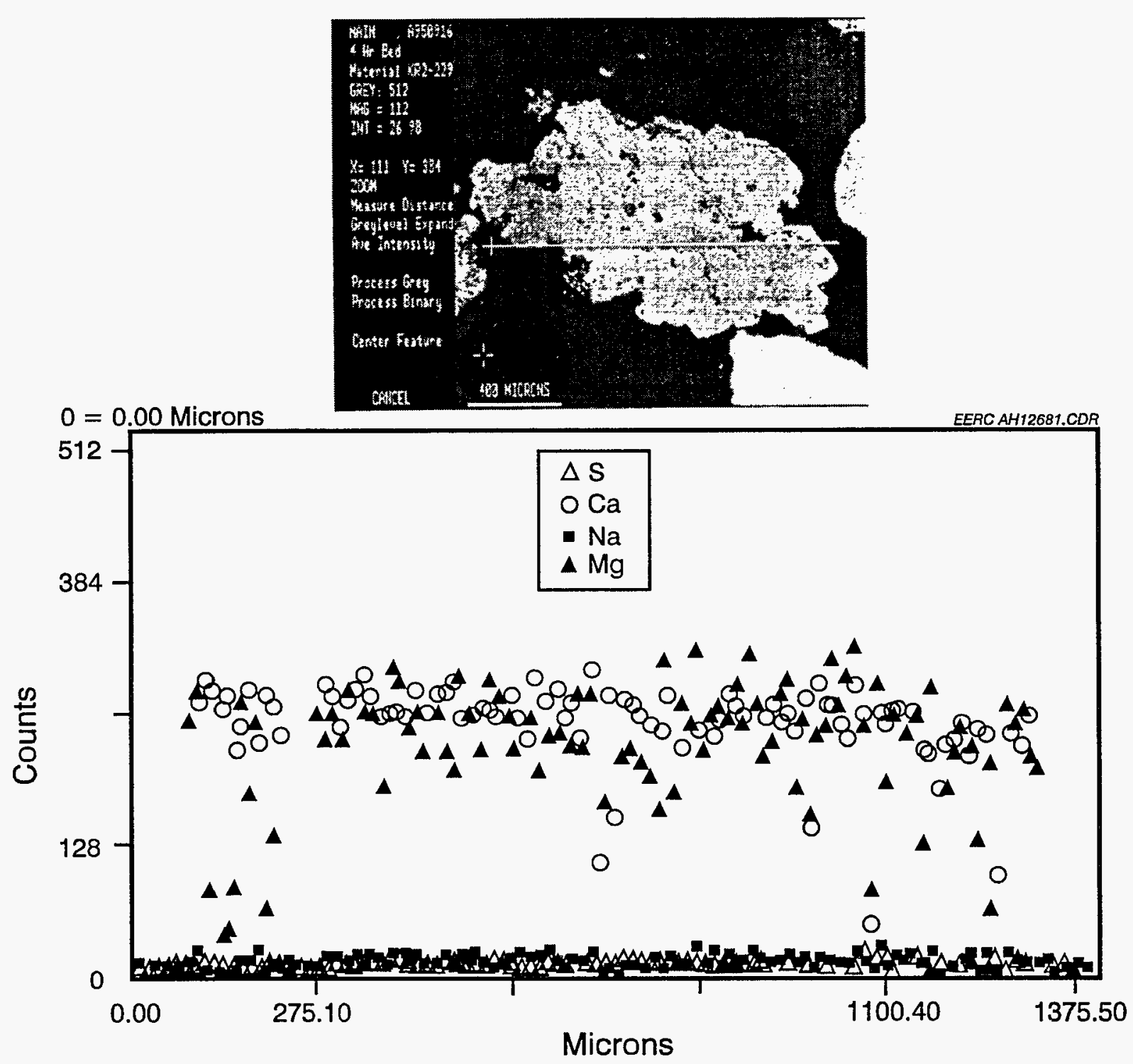

Figure 5-14. Line scan of a 4-hour bed particle from Test KR2-2295. 


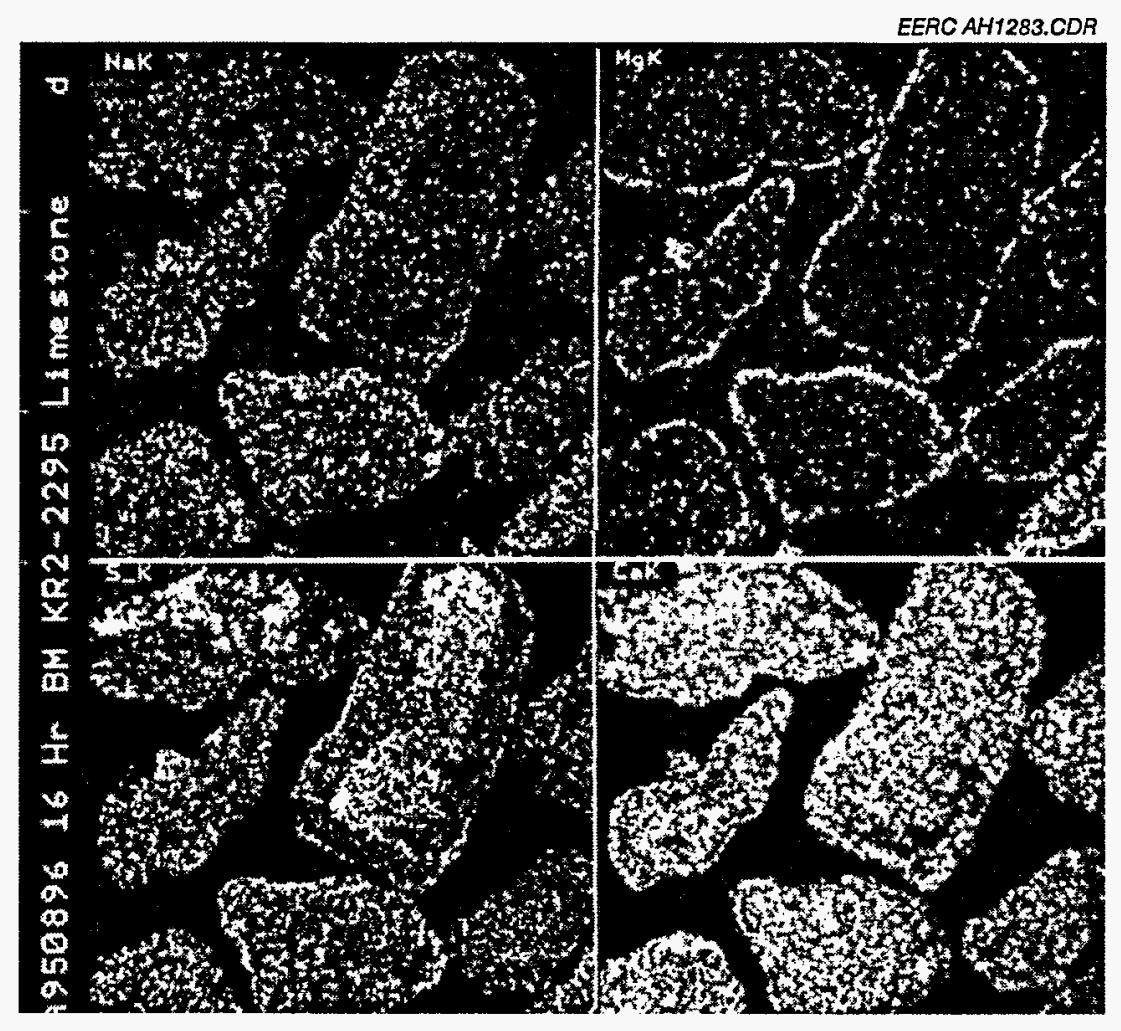

Figure 5-15. Elemental map of bed particles from Test KR2-2295.

Test KR1-0495 ended in defluidization after 3 hours of operation. Examination of the resulting agglomerate reveals particles of quartz, plagioclase, sodium aluminosilicate, sodium potassium magnesium aluminosilicate, and sodium calcium aluminosilicate bound in a fairly homogeneous matrix. Table 5-8 gives the average composition and standard deviation of 15 points in the matrix.

Test KR2-0695 ran for 8.5 hours without defluidizing, but some bed agglomerates were formed. Table 5-9 shows the chemical composition of points in the binding material, as well as the results of the bulk analysis of the bed material. The data show a lot of variability in the agglomerate matrix, but the predominant factors are either calcium sulfate or calcium silicate. Sodium and aluminum are present in all the points analyzed, but they are present in higher concentrations in the calcium sulfate regions.

Test PFB-B1-2495 was a high-pressure test which was terminated as a result of defluidization after 4 hours of operation. Two types of agglomerates were formed during the test: small agglomerates formed by particle sticking and sintered agglomerates. Table 5-10 compares the chemical analyses of the bed material coating, a small agglomerate, and a sintered agglomerate. The coating was composed of calcium sulfate aluminosilicate. The binding material in the small agglomerate contained much more silica and no sulfur. The binding material in the sintered agglomerate contained a high percentage of silica, less calcium than the coating or the small agglomerate, essentially no sulfur, and increasing levels of sodium. 


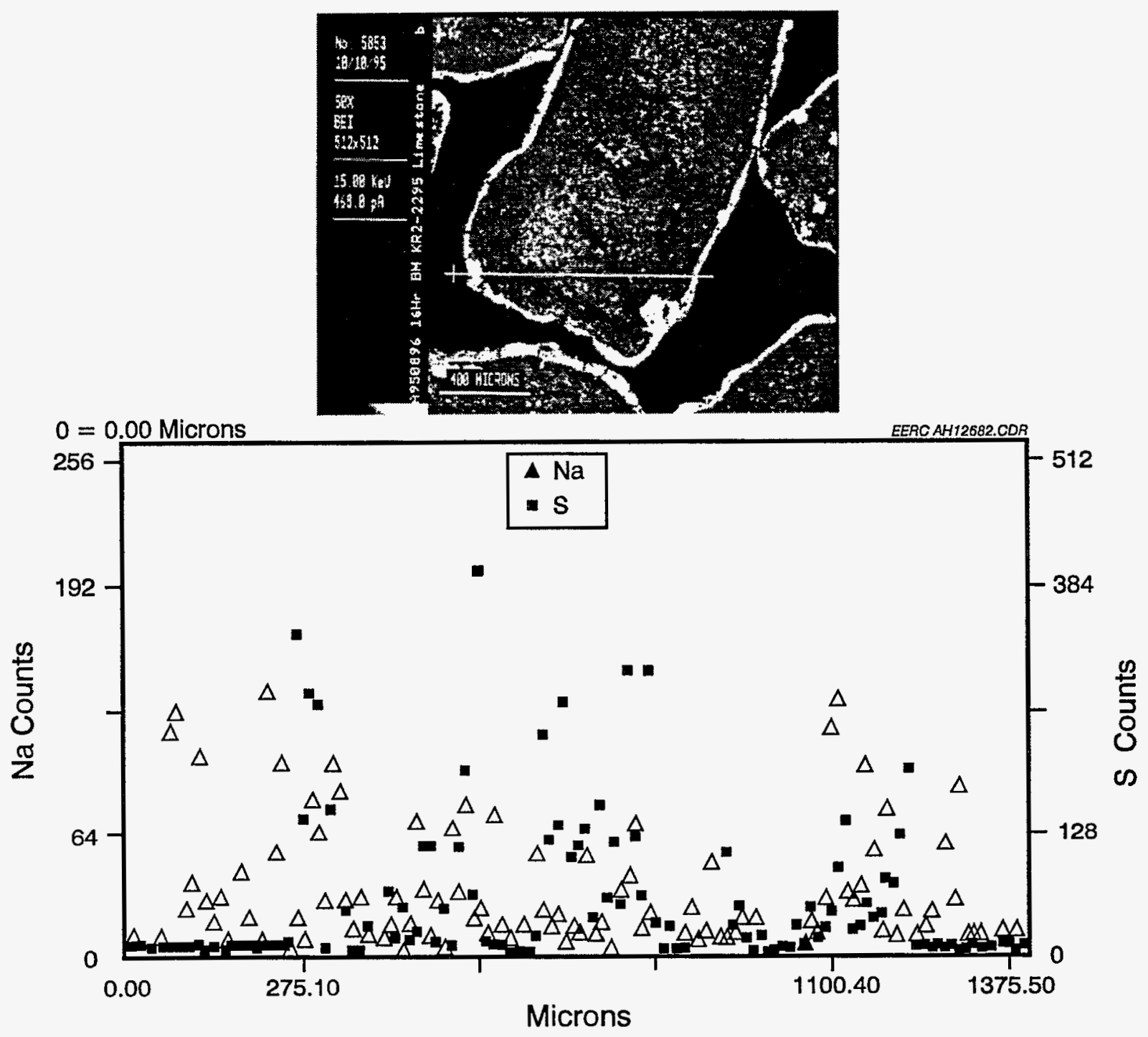

Figure 5-16. Line scan of a 16-hour bed particle from Test KR2-2295.

\subsubsection{Validation With Full-Scale Data}

Because the tests run on the bench-scale reactor used similar fuel and bed material as the Heskett Station, these results can be compared to establish the validity of the bench-scale unit as a predictive tool. Bulk analysis of the bed material shows excellent agreement between the two units (see Table 5-11). The largest difference is seen in the sodium and calcium contents, with higher calcium in the Heskett spent bed material and higher sodium in the EERC samples. This can be explained by the higher level of calcium in the fresh sand used at Heskett $(15 \% \mathrm{CaO}$ 
compared with $1.4 \%$ for the EERC start-up material), and the higher level of sodium in the coal used at the EERC (13\% compared to $6 \%$ for Heskett).

Morphological examination of the bench-scale samples also shows good comparability. Table 5-12 shows the analyses of several points in the coating from an EERC bed material sample taken from Test KR1-0595, as well a point from the coating on a bed material sample from Heskett. Both units develop a coating that is calcium-sulfate-based, with substantial amounts of aluminum, sodium, magnesium, and iron.

\section{TABLE 5-8}

\begin{tabular}{lrc}
\multicolumn{3}{c}{ Composition of Agglomerate Matrix from Test KR1-0495 } \\
\hline Oxides, \% & Average & Standard Deviation \\
\hline $\mathrm{SiO}_{2}$ & 45.7 & 3.29 \\
$\mathrm{Al}_{2} \mathrm{O}_{3}$ & 8.0 & 3.55 \\
$\mathrm{Fe}_{2} \mathrm{O}_{3}$ & 12.5 & 5.69 \\
$\mathrm{TiO}_{2}$ & 0.5 & 0.71 \\
$\mathrm{P}_{2} \mathrm{O}_{5}$ & 0.5 & 0.58 \\
$\mathrm{CaO}$ & 18.7 & 4.27 \\
$\mathrm{MgO}$ & 4.5 & 1.32 \\
$\mathrm{Na}_{2} \mathrm{O}$ & 7.7 & 2.47 \\
$\mathrm{~K}_{2} \mathrm{O}$ & 1.0 & 0.65 \\
$\mathrm{SO}_{3}$ & 0.9 & 0.70 \\
\hline
\end{tabular}

\section{TABLE 5-9}

Chemical Composition of Agglomerate from Test KR1-0695

\begin{tabular}{lrrrrrrrrrrrrr}
\hline & & & & & & & & & Bulk \\
Oxides, wt \% & Pt. 1 & Pt. 2 & Pt. 3 & Pt. 4 & Pt. 5 & Pt. 6 & Pt. 7 & Pt. 8 & Pt. 9 & Pt. 10 & Average & Analysis \\
\hline $\mathrm{SiO}_{2}$ & 3.90 & 0.27 & 1.03 & 2.10 & 12.29 & 2.24 & 40.67 & 47.58 & 44.14 & 43.21 & 19.74 & 58.39 \\
$\mathrm{Al}_{2} \mathrm{O}_{3}$ & 16.67 & 7.59 & 27.37 & 10.42 & 14.41 & 9.02 & 9.95 & 16.07 & 2.92 & 8.09 & 12.25 & 6.68 \\
$\mathrm{Fe}_{2} \mathrm{O}_{3}$ & 9.78 & 3.45 & 8.74 & 15.92 & 6.70 & 2.74 & 7.21 & 5.44 & 3.38 & 4.80 & 6.82 & 9.34 \\
$\mathrm{TiO}_{2}$ & 0.00 & 0.00 & 0.69 & 0.00 & 0.40 & 0.00 & 0.75 & 0.00 & 1.08 & 0.00 & 0.29 & 0.36 \\
$\mathrm{P}_{2} \mathrm{O}_{5}$ & 0.85 & 0.00 & 0.00 & 0.29 & 2.75 & 0.00 & 0.72 & 0.00 & 0.00 & 0.49 & 0.51 & 0.13 \\
$\mathrm{CaO}$ & 20.65 & 15.09 & 18.75 & 16.60 & 38.07 & 17.22 & 28.28 & 16.54 & 35.89 & 31.68 & 23.88 & 6.86 \\
$\mathrm{MgO}$ & 7.70 & 2.42 & 17.14 & 7.03 & 4.27 & 2.95 & 5.38 & 2.58 & 6.14 & 6.70 & 6.23 & 2.68 \\
$\mathrm{Na}_{2} \mathrm{O}$ & 10.89 & 21.45 & 6.69 & 13.00 & 5.80 & 16.91 & 6.08 & 9.46 & 3.53 & 4.91 & 9.87 & 8.46 \\
$\mathrm{~K}_{2} \mathrm{O}$ & 1.47 & 2.44 & 1.04 & 1.50 & 0.72 & 3.06 & 0.36 & 1.84 & 0.14 & 0.12 & 1.27 & 0.75 \\
$\mathrm{SO}_{3}$ & 28.09 & 47.29 & 18.55 & 33.14 & 14.59 & 45.88 & 0.60 & 0.50 & 2.79 & 0.00 & 19.14 & 6.35 \\
\hline
\end{tabular}

Table 5-13 shows the analyses of points in the agglomerate "glue" for Heskett; Table 5-14 shows the "glue" for an EERC agglomerate. Once again, the results are very similar, with the only real difference being in the higher sodium for the EERC sample, due to the higher sodium level in that coal. 
Deposits were collected from both the Heskett Station and from the bench-scale unit. A comparison of the chemical analyses of these deposits is shown in Table 5-15. The Heskett deposit was collected from the division wall; the EERC deposit was collected from the freeboard area of the reactor during Test KR1-0695, a high-temperature, high-excess air test. The data shown in Table 5-15 are the averages of 4 points for the Heskett sample and 10 points for the EERC sample. The biggest differences between the two deposits are in calcium and magnesium content; the calcium values are consistent with the calcium in each of the fuels, while the Heskett deposit shows a marked concentration of magnesium in the deposit.

TABLE 5-10

Comparison of Chemical Compositions of Bed Material Coating and Agglomerates from Test PFB-B1-2495

\begin{tabular}{lcccc}
\hline Oxides, \% & $\begin{array}{c}\text { Bed Material } \\
\text { Coating }\end{array}$ & $\begin{array}{c}\text { Small } \\
\text { Agglomerate }\end{array}$ & $\begin{array}{c}\text { Sintered } \\
\text { Agglomerate } \\
\text { (light area) }\end{array}$ & $\begin{array}{c}\text { Sintered } \\
\text { Agglomerate } \\
\text { (dark area) }\end{array}$ \\
\hline $\mathrm{SiO}_{2}$ & 20.7 & 43.8 & 49.7 & 45.5 \\
$\mathrm{Al}_{2} \mathrm{O}_{3}$ & 13.3 & 10.1 & 8.7 & 26.6 \\
$\mathrm{Fe}_{2} \mathrm{O}_{3}$ & 8.2 & 12.9 & 17.6 & 8.0 \\
$\mathrm{TiO}_{2}$ & 0.5 & 0.4 & 0.2 & 0.3 \\
$\mathrm{P}_{2} \mathrm{O}_{5}$ & 0.1 & 0.1 & 0.1 & 0.1 \\
$\mathrm{CaO}$ & 27.1 & 21.0 & 13.4 & 8.2 \\
$\mathrm{MgO}$ & 9.8 & 7.2 & 3.5 & 1.2 \\
$\mathrm{Na}_{2} \mathrm{O}$ & 6.4 & 4.0 & 5.9 & 9.0 \\
$\mathrm{~K}_{2} \mathrm{O}$ & 0.2 & 0.0 & 0.1 & 0.4 \\
$\mathrm{SO}_{3}$ & 13.6 & 0.5 & 0.8 & 0.7 \\
\hline
\end{tabular}

TABLE 5-11

Comparison of Bulk Analyses at Bench Scale and Full Scale

\begin{tabular}{lccc}
\hline Oxides, \% & $\begin{array}{c}\text { Heskett } \\
\text { Bed Drain }\end{array}$ & $\begin{array}{c}\text { KR1-0595 } \\
\text { Bed Drain }\end{array}$ & $\begin{array}{c}\text { KR1-0895 } \\
\text { Bed Drain }\end{array}$ \\
\hline $\mathrm{SiO}_{2}$ & 59.2 & 58.6 & 58.4 \\
$\mathrm{Al}_{2} \mathrm{O}_{3}$ & 7.6 & 7.3 & 6.7 \\
$\mathrm{Fe}_{2} \mathrm{O}_{3}$ & 7.0 & 7.7 & 9.3 \\
$\mathrm{P}_{2} \mathrm{O}_{5}$ & 0.0 & 0.3 & 0.1 \\
$\mathrm{CaO}$ & 12.6 & 6.2 & 6.9 \\
$\mathrm{MgO}$ & 3.8 & 3.0 & 2.7 \\
$\mathrm{Na}_{2} \mathrm{O}$ & 3.6 & 8.2 & 8.5 \\
$\mathrm{~K}_{2} \mathrm{O}$ & 0.5 & 1.1 & 0.8 \\
$\mathrm{SO}_{3}$ & 5.6 & 7.4 & 6.4 \\
\hline
\end{tabular}


TABLE 5-12

Comparison of Bed Material Coatings from EERC and Heskett

\begin{tabular}{lcrrrrrrr}
\hline $\begin{array}{l}\text { Oxides, } \\
\text { wt\% }\end{array}$ & $\begin{array}{c}\text { EERC } \\
\text { Point 4 }\end{array}$ & $\begin{array}{c}\text { EERC } \\
\text { Point 5 }\end{array}$ & $\begin{array}{c}\text { EERC } \\
\text { Point 6 }\end{array}$ & $\begin{array}{c}\text { EERC } \\
\text { Point 7 }\end{array}$ & $\begin{array}{c}\text { EERC } \\
\text { Point 8 }\end{array}$ & $\begin{array}{r}\text { EERC } \\
\text { Point 9 }\end{array}$ & $\begin{array}{r}\text { EERC } \\
\text { Average }\end{array}$ & Heskett \\
\hline $\mathrm{SiO}_{2}$ & 0.3 & 0.7 & 0.3 & 0.7 & 0.9 & 1.2 & 0.7 & 5.3 \\
$\mathrm{Al}_{2} \mathrm{O}_{3}$ & 6.2 & 11.1 & 5.3 & 6.4 & 6.3 & 12.1 & 7.9 & 11.0 \\
$\mathrm{FeO}_{2}$ & 5.2 & 5.3 & 10.7 & 8.1 & 4.4 & 6.6 & 6.7 & 10.7 \\
$\mathrm{CaO}$ & 33.1 & 24.1 & 28.9 & 24.9 & 28.8 & 28.0 & 28.0 & 15.6 \\
$\mathrm{MgO}$ & 9.2 & 12.0 & 5.7 & 11.2 & 8.1 & 15.8 & 10.3 & 9.0 \\
$\mathrm{Na} O$ & 8.6 & 13.9 & 9.4 & 8.0 & 15.8 & 7.9 & 10.6 & 13.0 \\
$\mathrm{~K}_{2} \mathrm{O}$ & 0.5 & 0.5 & 0.8 & 0.9 & 0.0 & 0.4 & 0.5 & 1.0 \\
$\mathrm{SO}_{3}$ & 36.3 & 31.9 & 38.2 & 39.9 & 35.2 & 27.7 & 34.9 & 31.0 \\
\hline
\end{tabular}

TABLE 5-13

Analyses of Selected Points from Heskett Agglomerate

\begin{tabular}{lccccc}
\hline $\begin{array}{l}\text { Oxides, } \\
\text { wt\% }\end{array}$ & Point 1 & Point 2 & Point 3 & Point 4 & Average \\
\hline $\mathrm{SiO}_{2}$ & 49.3 & 49.2 & 40.3 & 34.9 & 43.4 \\
$\mathrm{Al}_{2} \mathrm{O}_{3}$ & 19.9 & 12.0 & 10.4 & 8.8 & 12.8 \\
$\mathrm{Fe}_{2} \mathrm{O}_{3}$ & 7.1 & 9.5 & 12.4 & 26.3 & 13.9 \\
$\mathrm{CaO}$ & 12.1 & 13.5 & 28.4 & 22.7 & 19.2 \\
$\mathrm{MgO}$ & 3.9 & 6.5 & 1.8 & 5.4 & 4.4 \\
$\mathrm{Na}_{2} \mathrm{O}$ & 6.0 & 5.1 & 4.6 & 0.5 & 4.1 \\
$\mathrm{~K}_{2} \mathrm{O}$ & 1.6 & 1.2 & 1.1 & 0.0 & 1.0 \\
$\mathrm{SO}_{3}$ & 0.3 & 1.8 & 1.6 & 0.0 & 0.9 \\
\hline
\end{tabular}

TABLE 5-14

Analyses of Selected Points from EERC Agglomerate (KR1-0295)

\begin{tabular}{lrrrrrrr}
\hline $\begin{array}{l}\text { Oxides, } \\
\text { wt\% }\end{array}$ & Point 1 & Point 2 & Point 3 & Point 4 & Point 5 & Point 6 & Average \\
\hline $\mathrm{SiO}_{2}$ & 45.1 & 44.1 & 42.6 & 43.4 & 41.0 & 40.8 & 42.8 \\
$\mathrm{Al}_{2} \mathrm{O}_{3}$ & 9.5 & 10.5 & 9.8 & 10.6 & 9.7 & 9.7 & 10.0 \\
$\mathrm{Fe}_{2} \mathrm{O}_{3}$ & 10.3 & 8.5 & 10.8 & 15.0 & 14.5 & 13.5 & 12.1 \\
$\mathrm{CaO}$ & 14.7 & 20.6 & 19.3 & 10.4 & 16.6 & 19.1 & 16.8 \\
$\mathrm{MgO}$ & 4.5 & 5.6 & 5.0 & 4.3 & 5.0 & 4.8 & 4.9 \\
$\mathrm{Na}_{2} \mathrm{O}$ & 12.3 & 9.1 & 9.4 & 13.0 & 9.9 & 8.8 & 10.4 \\
$\mathrm{~K}_{2} \mathrm{O}$ & 0.5 & 0.8 & 0.8 & 0.5 & 0.6 & 0.6 & 0.6 \\
$\mathrm{SO}_{3}$ & 1.5 & 0.4 & 1.3 & 1.1 & 1.2 & 1.5 & 1.2 \\
\hline
\end{tabular}


TABLE 5-15

Comparison of Heskett and EERC Deposits

Average of Analyzed Points

\begin{tabular}{lrr} 
& Heskett & EERC \\
\hline $\mathrm{SiO}_{2}$ & 2.07 & 2.37 \\
$\mathrm{Al}_{2} \mathrm{O}_{3}$ & 8.00 & 7.36 \\
$\mathrm{Fe}_{2} \mathrm{O}_{3}$ & 3.12 & 6.56 \\
$\mathrm{CaO}$ & 18.90 & 27.55 \\
$\mathrm{MgO}$ & 12.43 & 5.17 \\
$\mathrm{Na}_{2} \mathrm{O}$ & 5.83 & 7.58 \\
$\mathrm{~K}_{2} \mathrm{O}$ & 0.11 & 0.44 \\
$\mathrm{SO}_{3}$ & 49.54 & 41.75 \\
\hline
\end{tabular}


6.0

FUNDAMENTAL STUDIES 


\section{TABLE OF CONTENTS}

6.0 FUNDAMENTAL STUDIES $\ldots \ldots \ldots \ldots \ldots \ldots \ldots \ldots \ldots \ldots \ldots \ldots \ldots$

\section{LIST OF FIGURES}

6-1 Schematic of the sintering test apparatus $\ldots \ldots \ldots \ldots \ldots \ldots \ldots \ldots \ldots$ 6-1

6-2 Displacement as a function of temperature using sintering apparatus $\ldots \ldots \ldots 6$ 6-2

6-3 Sinter temperature of ground bulk bed materials as a function of $\mathrm{Na}_{2} \mathrm{O} \ldots \ldots \ldots 6-3$

6-4 Shrinkage sintering characteristics of bed material from an agglomerating run . . . . 6-5

6-5 Distribution of liquid phases as a function of deposit temperature $\ldots \ldots \ldots \ldots 6-6$

\section{LIST OF TABLES}

6-1 Summary of Results Evaluating Agglomeration as a Function of Temperature Using a 2 -in. Bench-Scale FBR . . . . . . . . . . 6-4 


\subsection{FUNDAMENTAL STUDIES}

To help understand what chemical and physical characteristics of the mixture of silica sand and coal ash contributes to agglomeration, a laboratory-scale sintering apparatus was used to quantitatively compare the sintering properties of bulk bed materials collected from the pilotscale AFBC. The sintering process may promote aggregation by yielding large particles that defluidize, creating hot spots which experience temperatures sufficient to cause partial melting. An attempt was made to determine whether particle-particle behavior as observed in the sintering apparatus correlates with agglomeration observed in the pilot-scale unit.

The sintering test apparatus, shown in Figure 6-1, was used for these tests. Particle bonding strength is based on the relationships between temperature, electrical resistance, and shrinkage. Approximately 1 gram of uniformly sized sample was placed into an alumina crucible, forming a compact $10 \mathrm{~mm}$ in diameter and $10 \mathrm{~mm}$ high. The sample was externally heated in a $50-\mathrm{mm}-\mathrm{ID}$ tube furnace up to $2000^{\circ} \mathrm{F}$ at a rate of $15^{\circ}$ to $20^{\circ} \mathrm{F}$ per minute. The sample temperature was measured using a chromel/alumel thermocouple. An electrical circuit was established through the sample using platinum foil disks above and below the sample compact, with platinum leads connected to an ohmmeter for determination of electrical resistance. A linear variable differential transformer (LVDT) connected to the sample crucible was used to measure expansion or contraction of the sample compact.

During a typical sintering test, the data recorded by a microcomputer included time, temperature, electrical resistance, and vertical displacement from a reference point. The onset of sintering, the point at which particle-particle bonding begins, was identified in two ways: 1) the "electrical" sinter point occurs where a plot of the logarithm of resistance versus the

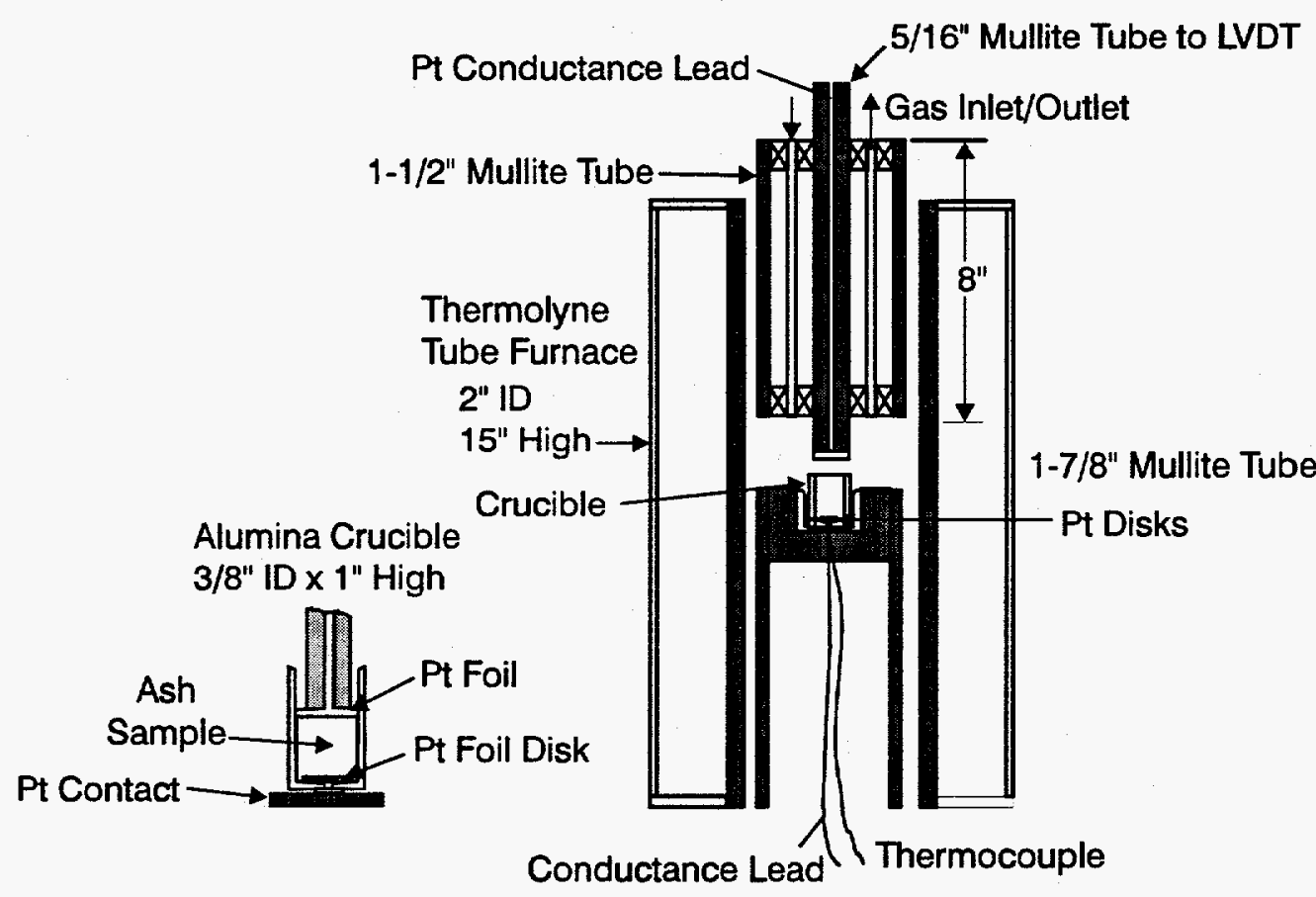

EERC MM12654.CDR

Figure 6-1. Schematic of the sintering test apparatus. 
reciprocal of absolute temperature undergoes a change of slope and 2) the "shrinkage" sinter point was marked where the change in displacement with temperature ceases, or where sample shrinkage occurs as evidenced by a decrease in vertical displacement with increasing temperature (Conn, 1984).

Bulk bed material samples tested in the sintering furnace were removed from both agglomerating and nonagglomerating tests in the pilot-scale AFBC. Figure 6-2 illustrates the results of two sinter tests obtained for a run in which agglomeration occurred. Data were first obtained for the ground bulk bed material. A plot of displacement versus temperature did not identify any visible indication of sintering. A second sample, consisting only of the bed material ash coating, showed significantly different results. Expansion was linear with temperature for the bulk bed material, whereas for the bed material ash coating, shrinkage began at about $1600^{\circ} \mathrm{F}$. It was postulated that discrete particles of silica sand present in the ground bed material, but not in the ash coating, acted as a rigid framework that did not shrink with heating. Therefore, even though sintering was occurring on the surface of the bulk material, detection of shrinkage of the ash layer was masked by the much thicker silica sand core.

As was discussed previously, sodium has been identified as playing a key role in the agglomeration process; however, the amount of sodium alone is not sufficient to determine whether agglomeration will be a problem. This is supported by testing with the sintering apparatus. A correlation between the sodium content of the bed and sintering temperature is presented in Figure 6-3. For the agglomerating test run, the sinter point temperature decreased with increased sodium in the bed material (reported as $\% \mathrm{Na}_{2} \mathrm{O}$ in sample). However, in the nonagglomerating test (ion-exchanged Beulah lignite) a nearly constant sinter point temperature was seen, even though the sodium content of the bed increased to levels similar to the agglomerating test. Therefore, if $\% \mathrm{NaO}$ in the bed material is to be used as an operational guideline to determine safe operation, each fuel/bed material/sorbent combination should be tested to determine the value of $\mathrm{NaO}$ to be used as a control point.

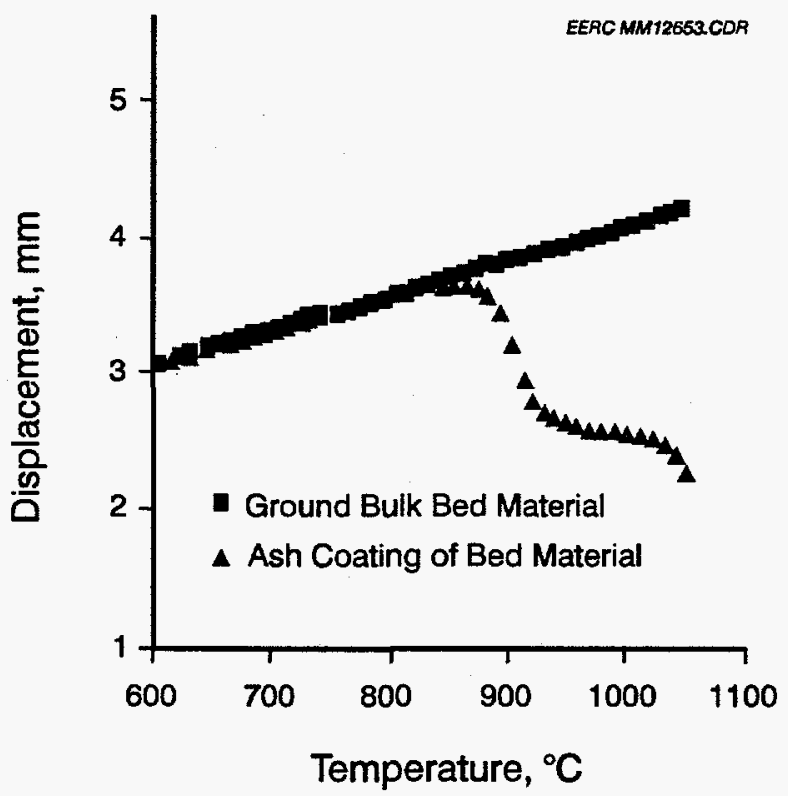

Figure 6-2. Displacement as a function of temperature using sintering apparatus. 


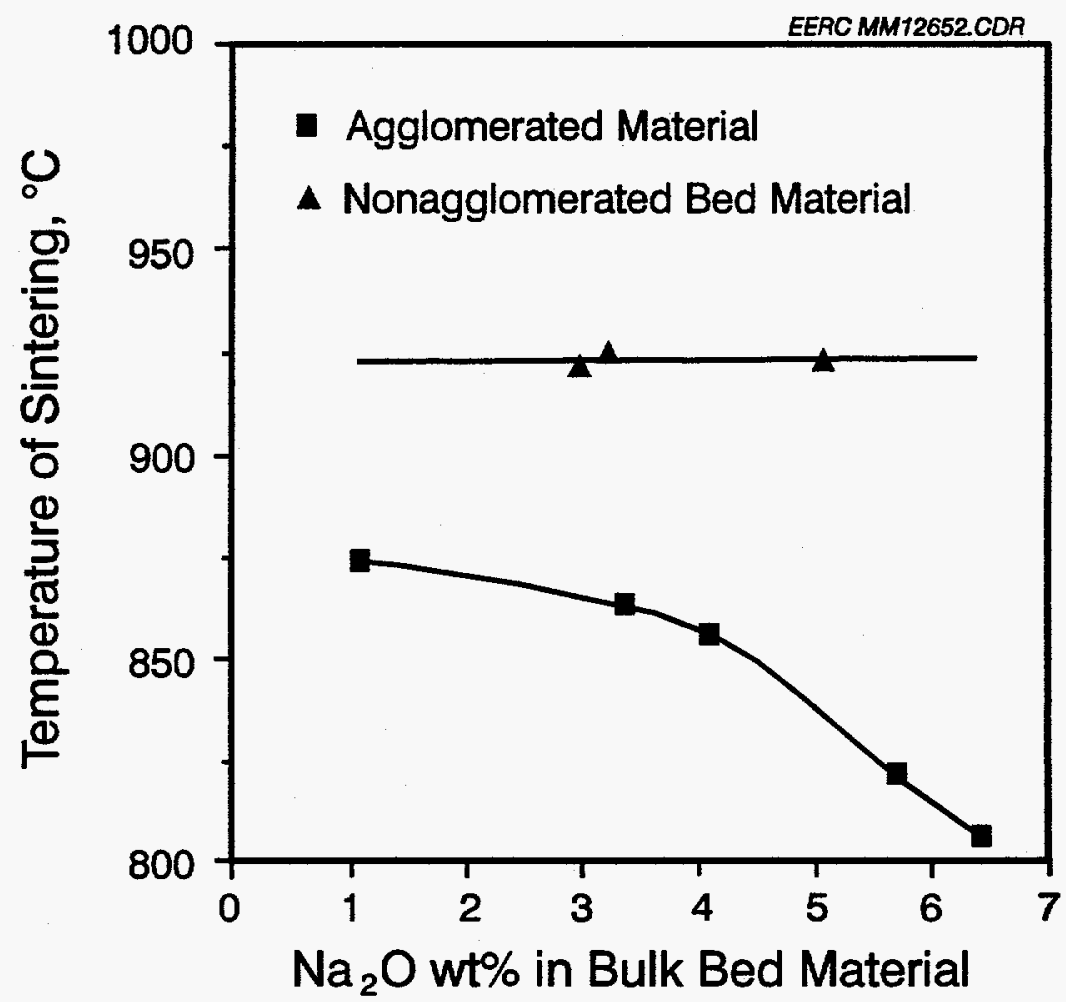

Figure 6-3. Sinter temperature of ground bulk bed materials as a function of $\mathrm{Na}_{2} \mathrm{O}$.

Previous tests performed on the EERC $2.25 \mathrm{ft}^{2}$ bubbling AFBC to determine the effects of temperature on bed agglomeration showed that temperatures above $1800^{\circ} \mathrm{F}$ exhibited severe agglomeration when burning a high-sodium Beulah lignite (Mann, 1986). Therefore, the bed operating temperature was controlled such that the temperature was maintained well below the point at which severe agglomeration occurs and also within a range that provides adequate sulfur capture in the bed. The test data presented in Table 6-1 indicate that agglomeration was also promoted at lower average bed temperatures, $1450^{\circ}$ to $1550^{\circ} \mathrm{F}$, but did not readily occur in tests performed at approximately $1650^{\circ} \mathrm{F}$. These data, when combined with data from earlier tests at higher temperatures, suggest an intermediate temperature range or window exists between $1550^{\circ}$ and $1650^{\circ} \mathrm{F}$ where the tendency for bed material agglomeration is significantly reduced. However, the data indicated that sulfur retention was lower at $1650^{\circ} \mathrm{F}$ compared to $1350^{\circ} \mathrm{F}$. Therefore, it will not be possible to operate in the optimal temperature range for sulfur capture when burning agglomerating coals.

To evaluate the effects of sulfur capture on agglomeration, bench-scale tests were conducted at the EERC in a 2-in. AFBC using simulated flue gas and redispersed high-sodium Beulah fly ash. As long as $\mathrm{SO}_{2}$ was not injected into the system, there was very little agglomeration of the bed material. When $\mathrm{SO}_{2}$ was added at a rate of $1000 \mathrm{ppm}$, the inherent alkali in the ash began to react with the sulfur, and agglomeration of the bed material occurred. This sulfation process, which tends to promote alkali attack of the bed material, will be discussed later in the report. Although it is unclear as to how much sulfur must be present in the coal before agglomeration occurs, it would be expected that agglomeration would be less problematic using a very low-sulfur coal. 


\section{TABLE 6-1}

Summary of Results Evaluating Agglomeration as a Function of Temperature Using a 2-in. Bench-Scale FBR ${ }^{1}$

\begin{tabular}{lcccccc}
\hline Test & 1 & 2 & 3 & 4 & 5 & 6 \\
\hline $\begin{array}{l}\text { Average Bed } \\
\text { Temp., }{ }^{\circ} \mathrm{F}\end{array}$ & 1478 & 1532 & 1675 & 1468 & 1650 & 1550 \\
$\begin{array}{l}\text { Superficial Gas } \\
\text { Velocity, ft/sec }\end{array}$ & 2.6 & 2.4 & 2.2 & 2.7 & 2.9 & 2.7 \\
$\begin{array}{l}\text { SO }{ }_{2} \\
\text { Concentration, } \\
\text { ppm }\end{array}$ & 0 & 0 & 0 & 1000 & 1000 & 1000 \\
$\begin{array}{l}\text { Duration of } \\
\text { Run, hr }\end{array}$ & 153 & 118 & 126 & 153 & 126 & 136 \\
$\begin{array}{l}\text { Mass-Mean, } \\
\text { EOR Particle } \\
\text { Diameter, mm }\end{array}$ & 0.69 & 0.80 & 0.95 & 1.16 & 0.98 & 1.09 \\
$\begin{array}{l}\text { Extent of } \\
\text { Agglomeration }\end{array}$ & None & None & Slight & Severe & Slight & Moderate \\
\hline
\end{tabular}

${ }^{1}$ Bed material was silica sand with injected Beulah fly ash.

Tests conducted using a sintering apparatus also tended to support the conclusion that a temperature window existed where the agglomeration potential is minimized. In Figure 6-4, two sinter points, A and C, are identified using the displacement method. A straight line plot with increasing temperature occurs up to Point $A$, where the onset of sintering is apparent as a change in the slope of the line. Expansion resumes at Point B and continues to Point $C$, where a second sinter point is observed. The temperatures do not correlate directly with those from the pilot-scale tests $\left(1550^{\circ}-1650^{\circ} \mathrm{F}\right.$ for the pilot-scale tests compared to $1725^{\circ}-1875^{\circ} \mathrm{F}$ for the sintering tests), primarily because the temperature range for the pilot-scale AFBC case represents average bed temperatures, while actual coal particle temperatures are significantly higher. These data are characteristic of numerous samples of bed material obtained from tests where agglomeration occurred. The same trends are not observed with bed material resulting from nonagglomerating tests.

The existence of optimal temperature ranges for ash-related problems has also been noted in studies of ash deposition in conventional boilers. Fouling problems in utility boilers have been classified into two principal types: high-temperature fouling and low-temperature fouling. This distinction is needed since the bonding mechanism of the deposits differs. Figure 6-5 illustrates the type of liquid components present as a function of temperature. At lower temperatures, sulfates dominate, while at higher temperatures, silicates are more prone to 


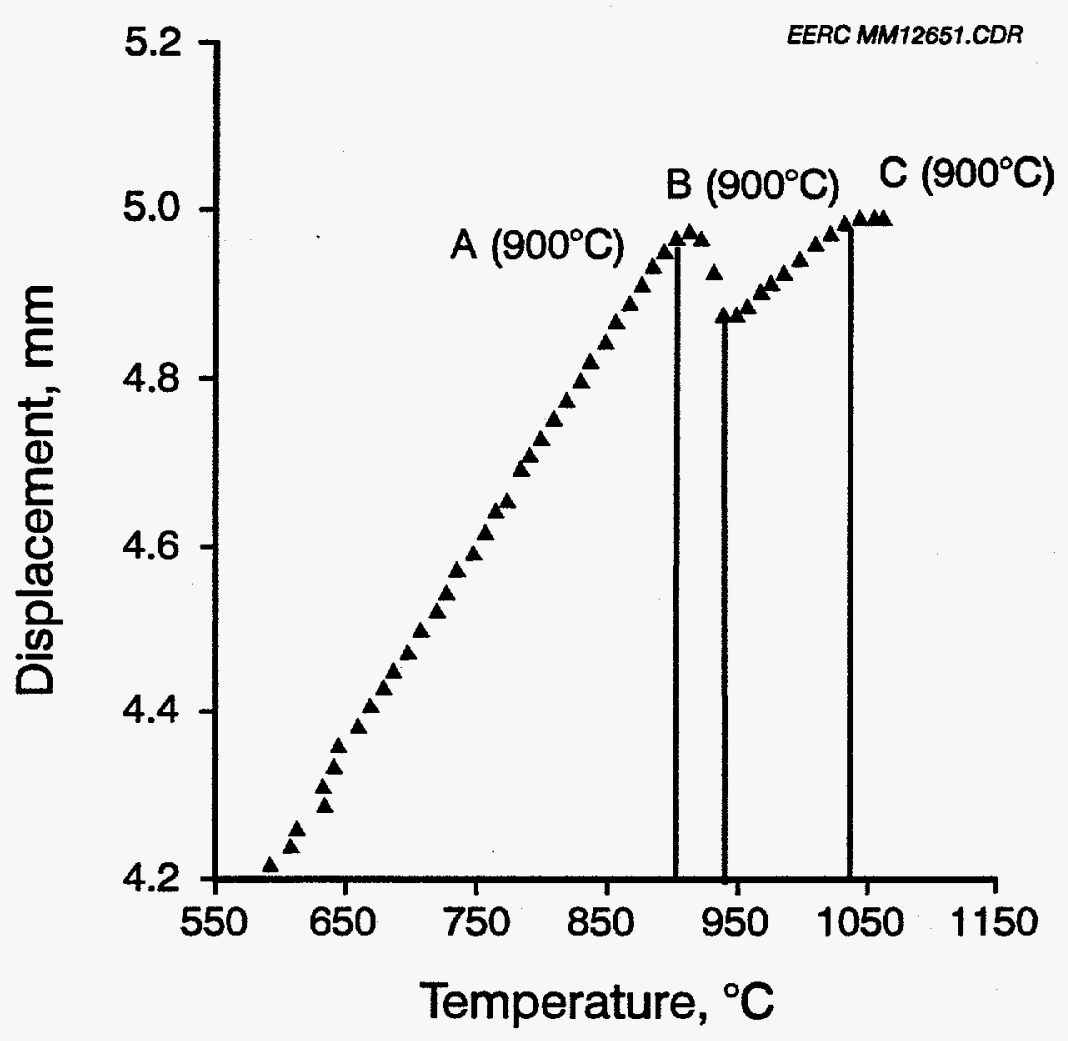

Figure 6-4. Shrinkage sintering characteristics of bed material from an agglomerating run.

produce liquids. In high-temperature fouling, the bonding of particles is due to silicate liquid phases, and in low-temperature fouling, the bonding is a result of the formation of sulfates. Condensed sulfur species, principally in the form of $\mathrm{CaSO}_{4}$, are stable and form the matrix or bonding material in the low-temperature deposits.

It is speculated that the temperature window where agglomeration is less severe corresponds to Region 14 in Figure 6-5, and the mechanisms for agglomeration change depending upon which side of this temperature window the FBC is operating at. It is also propositioned, without proof, that the temperature defining this window will shift, depending upon the type of fuel, firing rate, and excess in level. 


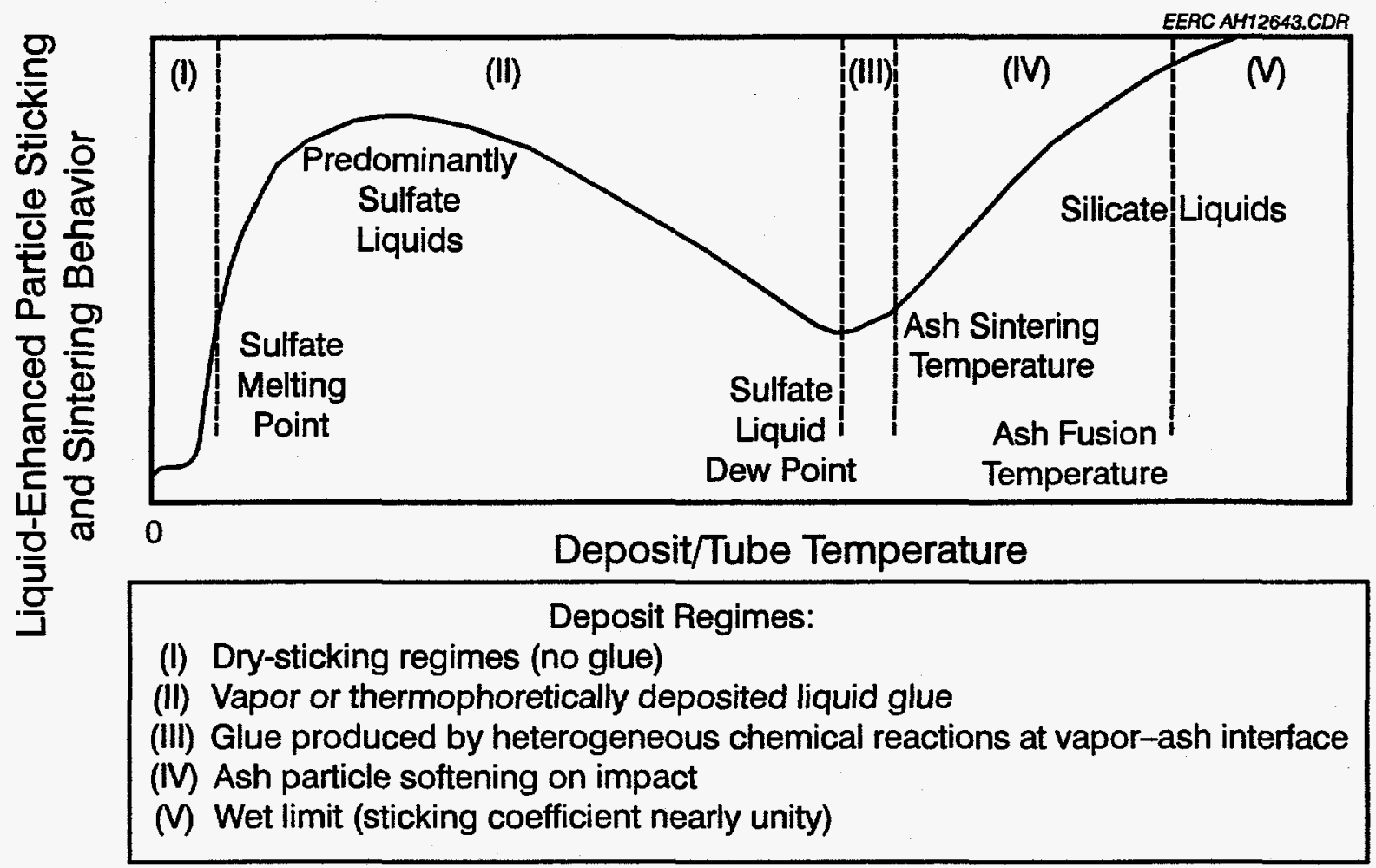

Figure 6-5. Distribution of liquid phases as a function of deposit temperature (Nagarajan and Anderson, 1988). 
7.0

\section{FLUIDIZED-BED AGGLOMERATION} AND DEPOSITION MECHANISMS 


\section{TABLE OF CONTENTS}

7.0 FLUIDIZED-BED AGGLOMERATION AND DEPOSITION MECHANISMS $\ldots \ldots 7-1$

7.1 Agglomeration Mechanisms $\ldots \ldots \ldots \ldots \ldots \ldots \ldots \ldots \ldots \ldots .7-1$

7.1.1 Stage 1 - Coating of Bed Particles with Ash $\ldots \ldots \ldots \ldots \ldots \ldots$ 7-3

7.1.2 Stage $2 \mathrm{~A}$ - Particle-to-Particle Bonding $\ldots \ldots \ldots \ldots \ldots \ldots \ldots$

7.1.3 Stage 2B - Deposition of Bed Particles on Coal . . . . . . . . 7-4

7.1.4 Stage 3 - Interaction of Ash and Limestone on Coal Surface . . . . . . 7-5

7.1.5 Stage 4 - Formation of a Melt on the Coal Surface . . . . . . . 7-6

7.1.6 Stage 5 - Coal Burnout Leaving Sintered Egg . . . . . . . . . . . 7-7

7.1.7 Alternative Mechanism - High-Temperature Agglomeration . . . . . . 7-7

7.1.8 Factors Enhancing Agglomerate Formation . . . . . . . . . 7-7

7.2 Ash Formation and Boiler Tube Fouling in Fluidized-Bed Combustion . . . . 7-8

\section{LIST OF FIGURES}

7-1 Agglomerates formed during Bench-Scale Test KR1-0695 $\ldots \ldots \ldots \ldots \ldots$ 7-1

7-2 Egg-type agglomerates collected from NSP's Black Dog Station $\ldots \ldots \ldots \ldots$ 7-2

7-3 Sintered agglomerates formed during Bench-Scale Test KR1-0395 $\ldots \ldots \ldots \ldots$ 7-3

7-4 Pictorial reproduction of the mechanisms of ash formation and bed material agglomeration in fluidized-bed combustion $\ldots \ldots \ldots \ldots \ldots \ldots \ldots \ldots \ldots$

7-5 Bed material stuck to the surface of a particle, formed during

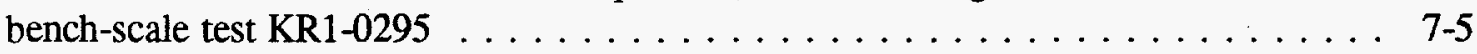

7-6 SEM micrograph showing the plasticity of coal particles $\ldots \ldots \ldots \ldots \ldots$ 7-6

7-7 Ash formation and fouling in fluidized bed combustion $\ldots \ldots \ldots \ldots \ldots$ 7-19 


\subsection{FLUIDIZED-BED AGGLOMERATION AND DEPOSITION MECHANISMS}

\subsection{Agglomeration Mechanisms}

Bed material agglomerates can typically be classified into four distinctly different categories. One type of agglomerate forms from relatively small bed particles that stick together, forming larger masses of bed material. In this case, coal ash reacting with bed material forms the substance which acts as the "glue" in agglomeration. These ash-related interactions occur under normal atmospheric FBC operating conditions and include the formation of low melting points between sodium-, potassium-, calcium-, and sulfate-rich components and possibly some solid-solid reactions. These agglomerates have a solid core and resemble raspberries. Figure 7-1 shows this type of agglomerate, formed in the bench-scale reactor during Bench-Scale Test KR1-0695.

The second type of agglomeration appears as hollow "eggs." These can be drained out of the bed with spent bed material in mild cases, but will cause defluidization and a forced shutdown in severe cases. These agglomerates form around burning coal particles. After the coal burns out, a hollow, egg-shaped agglomerate remains. Agglomerates ranging from about $1 / 2$ in. to 3 in. in diameter have been noted by EERC personnel from various units. An example of egg-type agglomerates, collected from NSP's Black Dog Station, is shown in Figure 7-2.
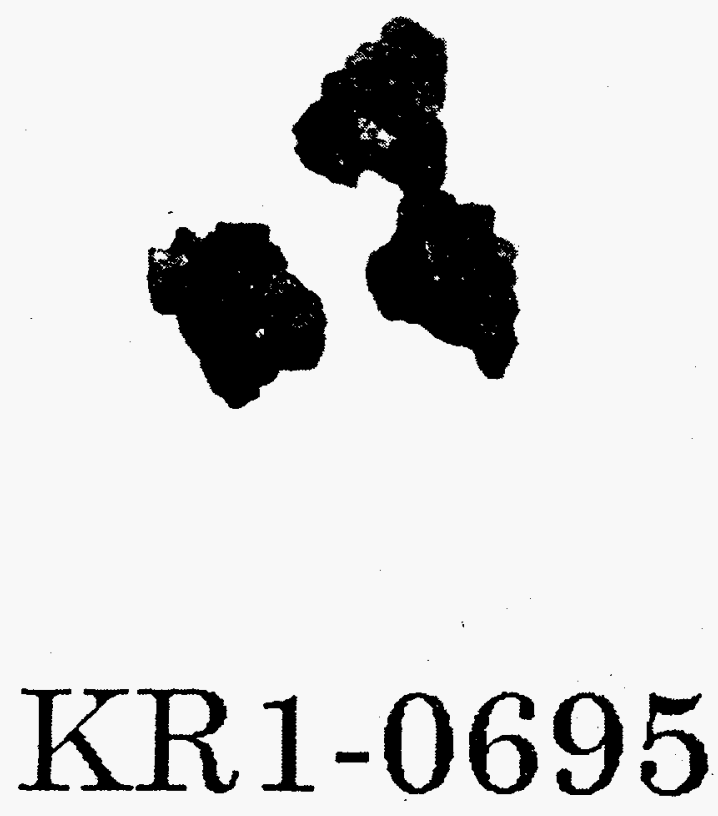

Figure 7-1. Agglomerates formed during Bench-Scale Test KR1-0695. 


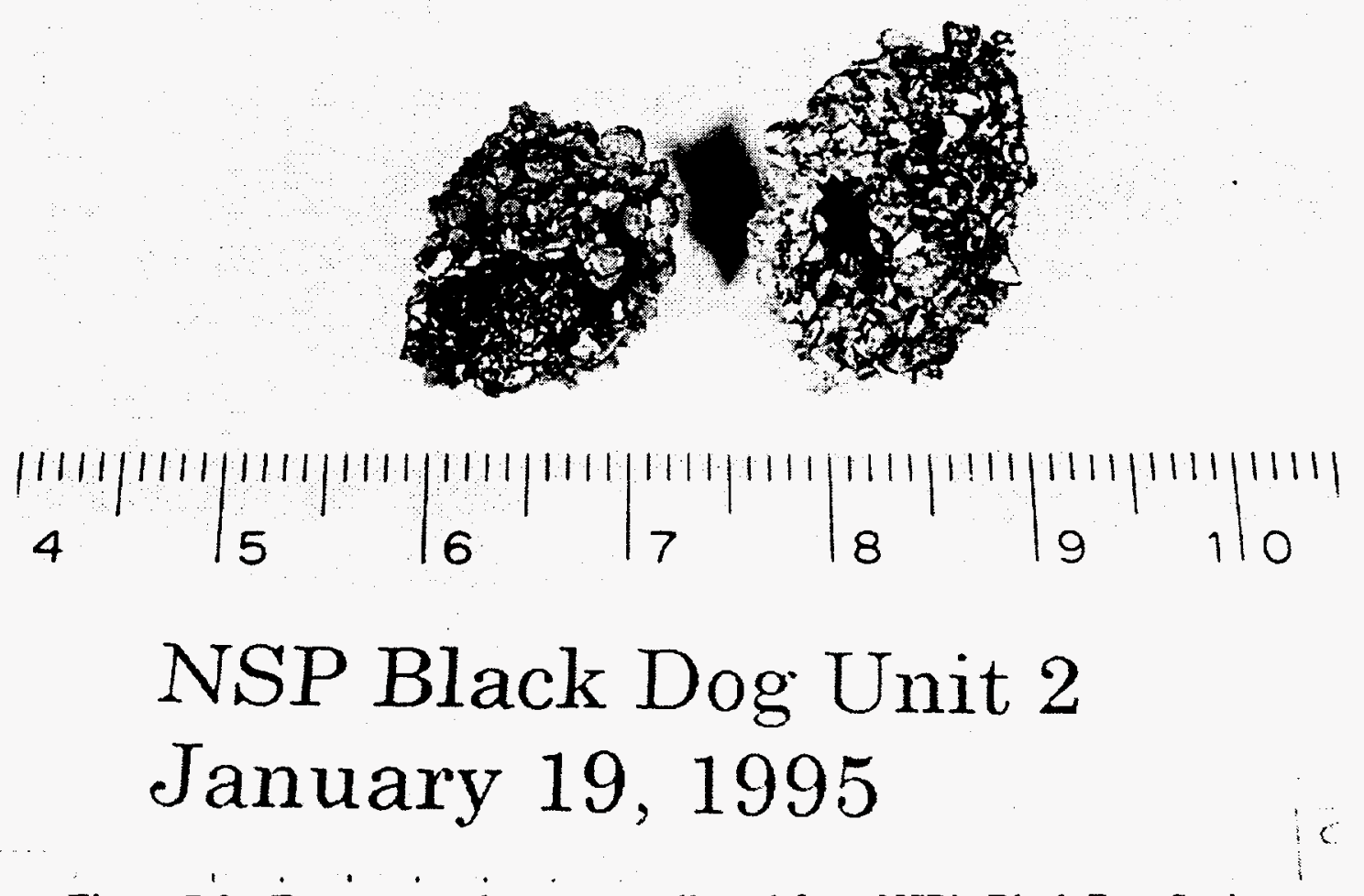

Figure 7-2, Egg-type agglomerates collected from NSP's Black Dog Station.

A third type of agglomeration is the result of localized hot spots of bed material, where temperatures in the FBC can exceed the typical $1700^{\circ} \mathrm{F}$ limit. Temperatures capable of melting various ash species can be attained even during relatively stable operation of an FBC. This type of agglomerate appears as a sintered mass with obvious signs that meiting had occurred. This type of agglomerate is typical of localized zones of poor fluidization, such as those that may exist during start-up or turndown of a multicell unit. Agglomerates of this type are also formed when defluidization occurs because of other mechanisms, and local temperatures increase because of poor fluidization. Figure 7-3 shows an example of this occurrence for Bench-Scale Test KR1-0395.

A fourth type of agglomerate consists mainly of sintered fly ash, with some fine sorbent material intermixed. This type of agglomerate is very fine-grained and dense. Typically these agglomerates are much weaker and can be broken up more easily than can the other three types of agglomerates. These sintered fly ash agglomerates are more commonly found in loop seals or other areas of low or stagnant flow.

The primary components of the fuel that are typically associated with agglomeration are the alkaline earth elements, specifically organically bound or water-associated sodium or potassium. Other elements that have been associated with agglomeration in atmospheric systems at normal operating temperatures $\left(<1700^{\circ} \mathrm{F}\right)$ include iron, vanadium, and calcium. Higher operating temperatures and pressures can also cause certain silicon and aluminum compounds to participate in the agglomeration mechanisms. 


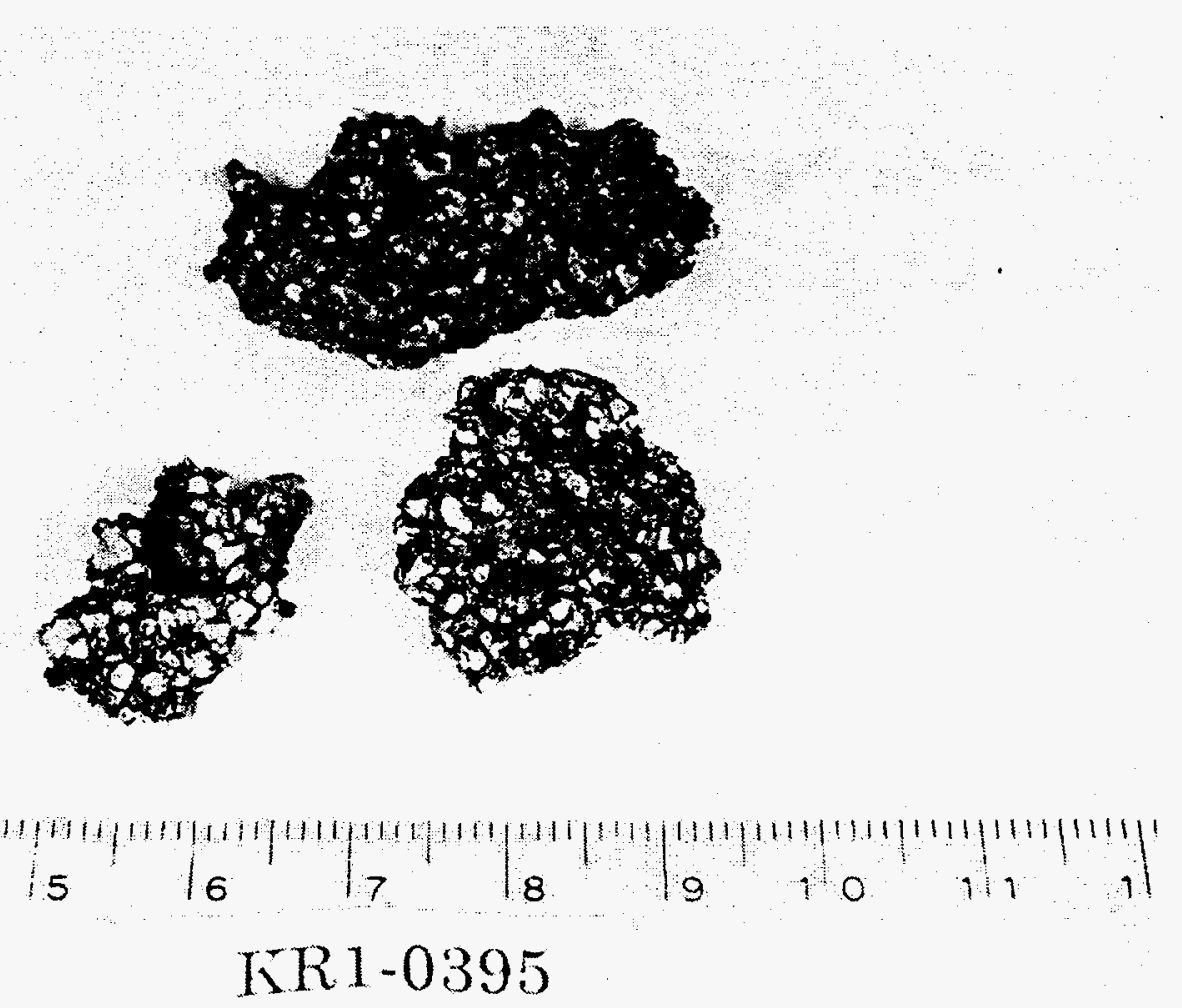

Figure 7-3. Sintered agglomerates formed during Bench-Scale Test KR1-0395.

Based on the results of full-scale sampling, bench-scale testing and fundamental studies, a mechanism of agglomerate formation was proposed. This mechanism is shown pictorially in Figure 7-4.

In this mechanism, agglomerates can be formed via the first or second mechanism presented above. The first mechanism leads to the formation of fly ash, fine-grained liquid minerals, and vapor-phase species (such as $\mathrm{Na}, \mathrm{K}$, and $\mathrm{S}$ ). The vapor-phase species via heterogeneous condensation and the fine-grained liquid minerals stick on the surface of the bed particles, which builds up a sticky ash layer on the surface of the bed material. This layer eventually becomes thick enough to result in particle-to-particle bonding and neck growth. Further exposure results in pore filling to form solid agglomerates. In the second mechanism, sticky bed material particles stick to the surface of a burning coal particle and as the particle shrinks because of the depletion of carbon from the char particle, eventually a continuous layer of bed particles and ash material is formed. Further combustion of the char particle under the ash layer eventually results in the formation of hollow egg-shaped agglomerates.

\subsubsection{Stage 1-Coating of Bed Particles with Ash}

Bed particles become coated by certain constituents from the coal ash, namely, sulfates of the alkali and alkaline-earth elements. The mechanisms of this selective coating are not fully understood. One possibility is that as coal burns, the alkali and alkaline-earth elements become partially molten. As the coal particles come into contact with the bed particles, this sticky ash rubs off onto the bed material and eventually builds up a coating. The other 


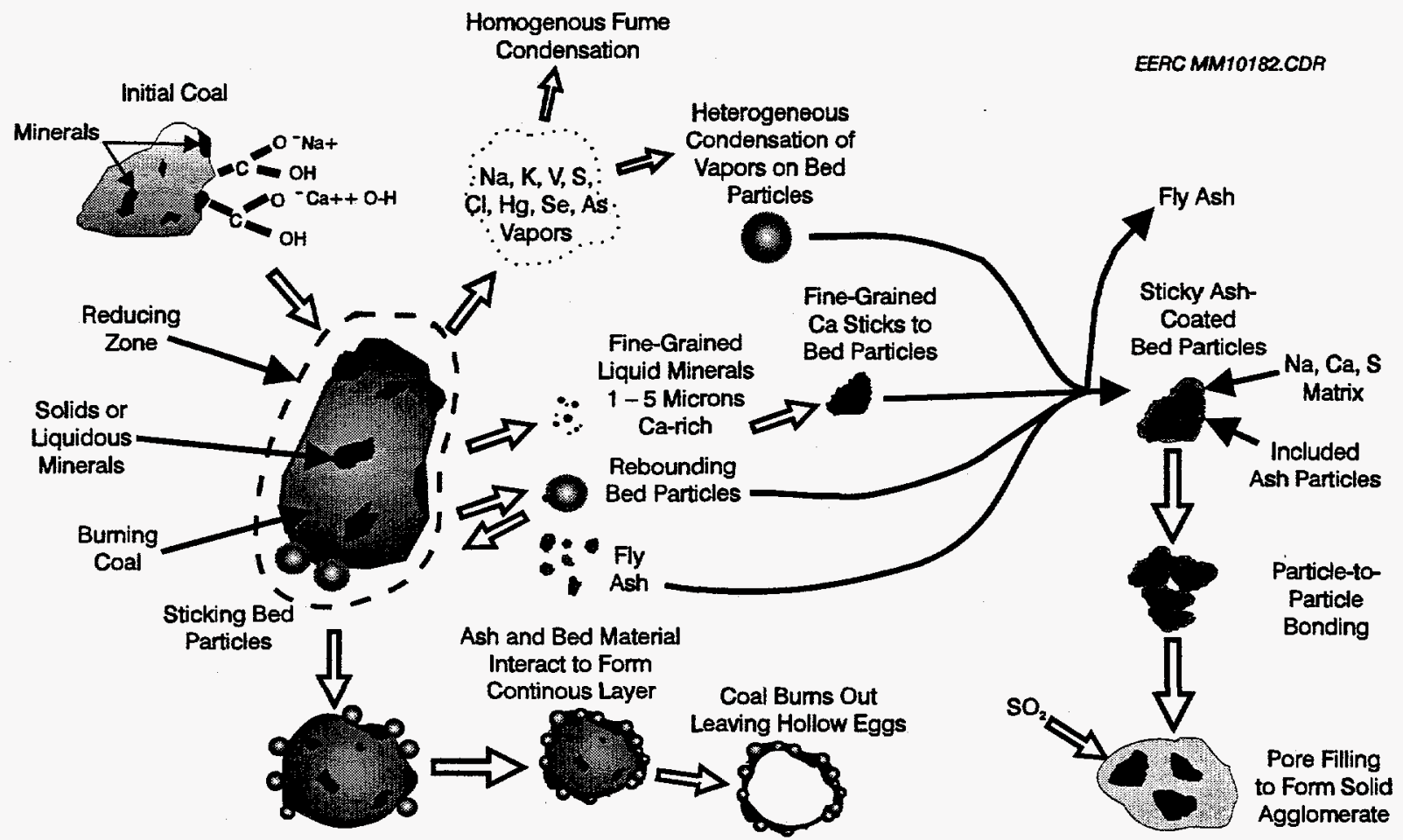

Figure 7-4. Pictorial reproduction of the mechanisms of ash formation and bed material agglomeration in fluidized-bed combustion.

other possibility is a condensation mechanism, whereby the elements such as sodium are volatilized during coal combustion and condense on the cooler bed particles. The agglomeration process can then occur via two alternate mechanisms. These mechanisms are shown as either Stage 2A or Stage 2B.

\subsubsection{Stage 2A - Particle-to-Particle Bonding}

In this mechanism, sulfation of the alkaline-earth elements to form alkali sulfates occurs. This results in the formation of a $\mathrm{Na}-\mathrm{Ca}-\mathrm{S}$-based matrix forming on the surface of the bed particle. This matrix material is then impacted by additional ash species which stick to the matrix surface. The addition of more alkali sulfate material and additional ash particles continues until a thick coating (approximately $10 \%$ of the particle diameter) is achieved. At this stage, enough ash particles have enough sticky surface to cohere to other alkali sulfatecoated particles and form a larger particle. As a result of more alkali sulfate deposition, sintering and neck growth occurs between these joined particles. This process continues with additional particle-to-particle bonding and pore filling to form solid agglomerates.

\subsubsection{Stage $2 B$ - Deposition of Bed Particles on Coal}

In this mechanism, the coated bed particles stick to the surface of the burning coal particle. The sticky surface of the coal particles holds the bed particles on the surface. This sticky nature of the coal particle is due to the plasticity of certain coal macerals during heating. 
Figure 7-5 shows an agglomerate formed by bed particles stuck to the surface of coal as formed during Bench-Scale Test KR1-0295. A closeup of the plasticity of the coal surface is shown in Figure 7-6. The coated bed particles themselves are also likely to be sticky because of the low melting temperature of the ash coating.

Many of the bituminous coals, especially those with a high free-swelling index, go through a plastic stage when heated. Certain macerals in lignitic and subbituminuous coals also exhibit this characteristic. During this stage, the coal particles tend to stick together to form larger conglomerates of coal. The surface of the coal particle also becomes sticky and is not necessarily dependent on the formation of sticky bed particles to form. Particles of limestone and dolomite from the bed stick to the surface of the burning coal conglomerate. Thus the sticky surface of the high-swelling coal particles holds the bed particles on the surface.

\subsubsection{Stage 3 - Interaction of Ash and Limestone on Coal Surface}

As the coal burns, the ash present in the coal is left behind. According to the shrinkingcore model, the coal burns from the surface inward, and the coal particle becomes smaller in size as it burns. The ash in the coal is left behind on the surface of the coal particle, at the approximate temperature of the burning coal particle. The ash that is left on the surface as the coal burns interacts with the bed particles.

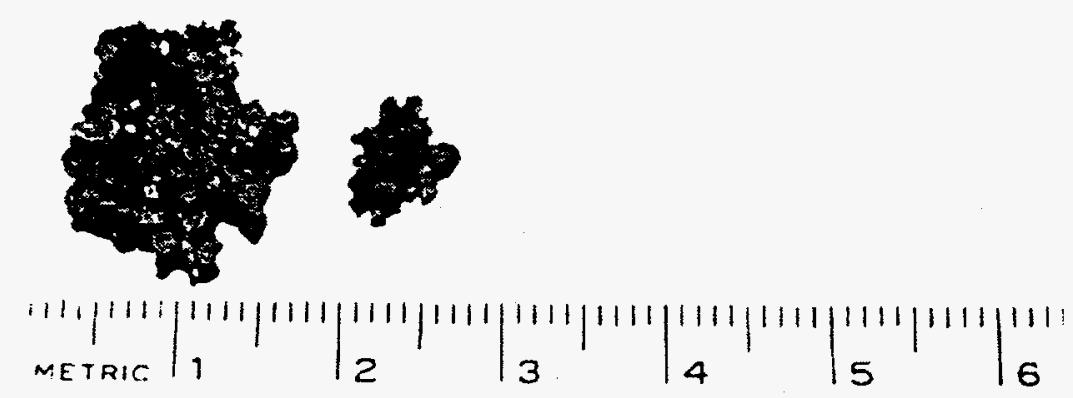

\section{KR1-0295}

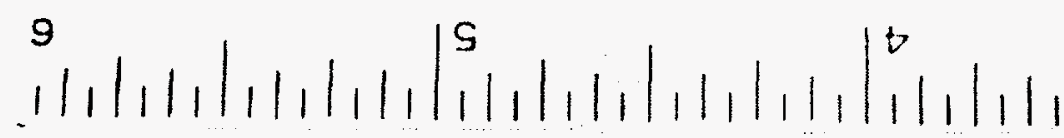

Figure 7-5. Bed material stuck to the surface of a particle, formed during bench-scale test KR1-0295. 


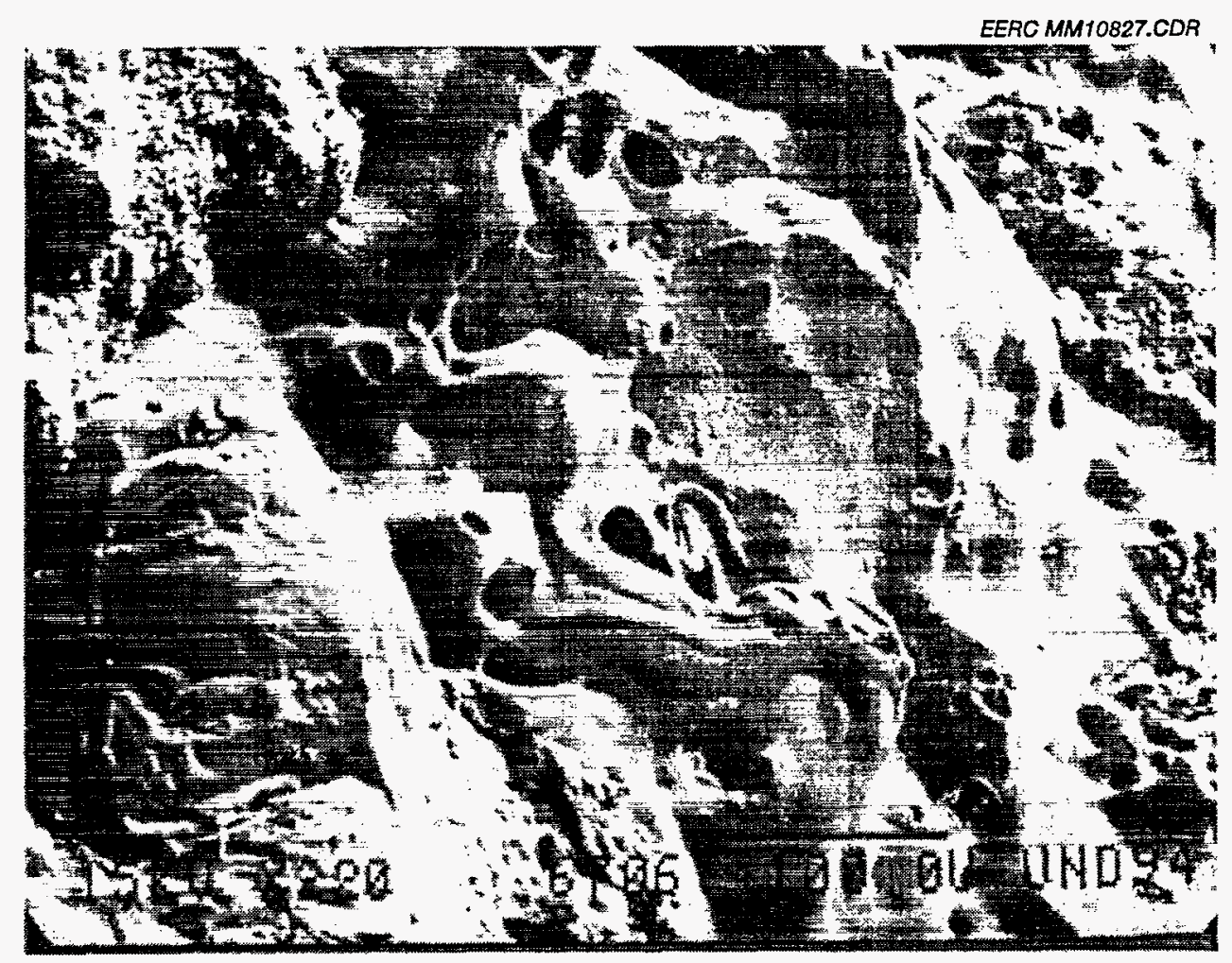

Figure 7-6. SEM micrograph showing the plasticity of coal particles.

\subsubsection{Stage 4 - Formation of a Melt on the Coal Surface}

As the coal continues to burn, the concentration of ash on the surface increases, as do the interactions between the fine-grained alkali sulfate coatings and the ash. As a result of these interactions, an amorphous glass will form. Glass is essentially a liquid with a very high viscosity. Glasses become solid very slowly, with the viscosity constantly increasing until the glass takes on the characteristics of a solid. This glass becomes the most important phase as it leads to increased bonding and sintering of the ash particles.

In the particular system at the MDU Heskett Station, the fine-grained quartz and the aluminosilicate clays left on the surface of the coal particle as it burned were interacting with the fine-grained calcium and sodium particles. In the particular system at Tidd, the fine-grained potassium-alumina-silicate clays that are left on the surface of the coal particle as it burns are interacting with the fine-grained calcium particles. These processes were indicated by the presence of the alkaline aluminosilicates in the agglomerates. Calcium and sodium act as network modifiers in these processes. A network modifier breaks some of the oxygen bonds that provide structure to the clays, resulting in a material with a lower melting temperature. The temperature at which the ash-sorbent mixture will become liquid is a function of its composition.

To provide sufficient material to form a continuous melt phase around the coal particle and an eventual egg-shaped mass after the coal has been burned out, sufficient ash material 
must be present. Therefore, a minimum coal size is most likely necessary to form the eggs. The coal size must be large enough so that the ash layer left on the coal surface (as the coal burns out) will be of sufficient thickness to form a continuous layer. Any particle smaller than this minimum size will not generate enough ash on the surface to form an egg. This minimum size will be a function of ash quantity in the coal and its mineral composition.

\subsubsection{Stage 5 - Coal Burnout Leaving Sintered Egg}

Once a sufficient quantity of ash is present on the coal surface to form a continuous layer, the coal will continue to burn out, leaving this layer as a hollow sphere. Evidence of the coal particle burning out and leaving a hollow egg was found in samples of agglomerates from the Heskett Station.

\subsubsection{Alternative Mechanism - High-Temperature Agglomeration}

The third mechanism discussed in the background section is the formation of agglomerates associated with the melting of alumina-silicate material. As a result of poor fuel-air mixing due to operational procedures or the presence of oversized agglomerates, localized hot spots can form in the fluidized bed. These localized hot spots lead to the formation of a liquid alumina-silicate-based phase, resulting in the accelerated formation and growth of agglomerates. These agglomerates generally do not form during normal FBC operation but are the result of a process upset in the fluidized-bed combustion process.

\subsubsection{Factors Enhancing Agglomerate Formation}

Egg-type agglomerates will form if conditions within the bed promote melting of the fuel ash. Therefore, agglomeration is enhanced by the mineral content of the fuel. The size and composition of the minerals in the fuel must be known to determine whether agglomerates may be a problem with a particular fuel.

Agglomeration is enhanced by local reducing zones, since the liquidus temperature of the mixture is lower for reducing than for oxidizing zones. The viscosity is also lower in the reducing zones, making sinter formation easier.

Agglomeration becomes more severe when the melting temperatures of the various mineral phases are approached. Therefore, higher temperature, especially at the surface of the burning coal particle, will enhance agglomeration.

As pressure increases, even for a fixed-bed temperature, the temperature of the burning coal particle increases. This increase in temperature is caused by the high reaction rates related to the higher partial pressure of oxygen.

The propensity to agglomerate increases with the presence of a fluxing agent. Sodium and calcium are good fluxing agents, lowering the melting point of certain silicate-based clays. The ability of the calcium to flux increases as the particle size decreases because of the increased surface area. 


\subsection{Ash Formation and Boiler Tube Fouling in Fluidized-Bed Combustion}

The ash formation and fouling mechanism for boiler tube deposition is shown in Figure

7-7. This mechanism shows that the combustion of the initial coal particles again results in the formation vapor-phase species (such as $\mathrm{Na}, \mathrm{K}, \mathrm{S}$ ) and the formation of fine-grained liquid droplets (as sodium or calcium-rich oxides and sulfates), and larger fly ash particles. The larger particles tend to have higher concentrations of silicon and alumina and a lower concentration of calcium than the smaller particles. The higher concentration of silicon and alumina in the larger particles is the result of these minerals occurring in the coal as larger particles. The higher concentration of the sodium and calcium in the smaller particles is because most of these elements in the coal are organically associated. Thus the sodium/calcium vaporizes during combustion but condenses as it moves away from the hotter char particle to form 1- to 5- $\mu \mathrm{m}$ oxide particles. Thus coals with more organically bound cations of sodium and calcium show higher deposition rates than coals with no alkalies or clay-associated alkalies. Certain aluminosilicates present in the coal ash have been shown to react with some of the alkali elements, thereby reducing the alkali-induced deposition.

A separate project at the EERC has shown that in pc-fired utility boilers two types of deposits form: high-temperature deposition, which are composed primarily of glassy silicatebased ash that is sticky above approximately $2000^{\circ} \mathrm{F}$, and low-temperature deposition, which is composed primarily of small calcium, magnesium, and sodium sulfate particles. Four types of low-temperature deposition were identified: upstream massive, upstream enamel, doublecrested upstream, and downstream powder deposits. Low-temperature fouling is characterized by high sulfur deposits that form at temperatures below $1900^{\circ} \mathrm{F}$ and it has been determined that the majority of the sulfation of the deposits occurred after deposition of the ash.

Transportation mechanisms for small particles are different from the inertial impact mechanism seen for larger particles. These mechanisms occur only in the boundary layer immediately surrounding a heat-transfer surface, and include thermophoresis, electrophoresis, Brownian diffusion, and eddy diffusion. Thermophoresis, caused by a thermal gradient, and electrophoresis, caused by an electrical or charge gradient, both decrease as the deposit gets larger. A larger deposit insulates the heat-transfer surface, thereby decreasing the gradient. However, Brownian and eddy diffusion continue as long as incoming ash particles will stick to the surface.

Because of the low flue gas temperatures $\left(<1700^{\circ} \mathrm{F}\right)$, the types of deposits seen in $\mathrm{FBCs}$ generally only consist of the last three types. The upstream enamel is a thin, hard, enamel-like layer that is formed from small particles $(<3 \mu \mathrm{m})$, with a very high calcium-to-silicon ratio. These small particles are transported to the heat exchanger surface through the boundary layer via thermophoresis, electrophoresis, and, most predominately, simple diffusion. These deposits then sinter in place by sulfation and become difficult to remove. These sulfation reactions are generally occurring in the temperature range below $1700^{\circ} \mathrm{F}$ and stop below temperatures of $1150^{\circ} \mathrm{F}$. While these deposits are difficult to remove with sootblowers, thermal shocking by spraying with water as the blowing fluid should be more effective. These deposits do not affect heat transfer significantly but serve as anchoring platforms and sticky surface for more massive deposits to form. The deposit fraction is directly proportional to the ratio of the square of the 


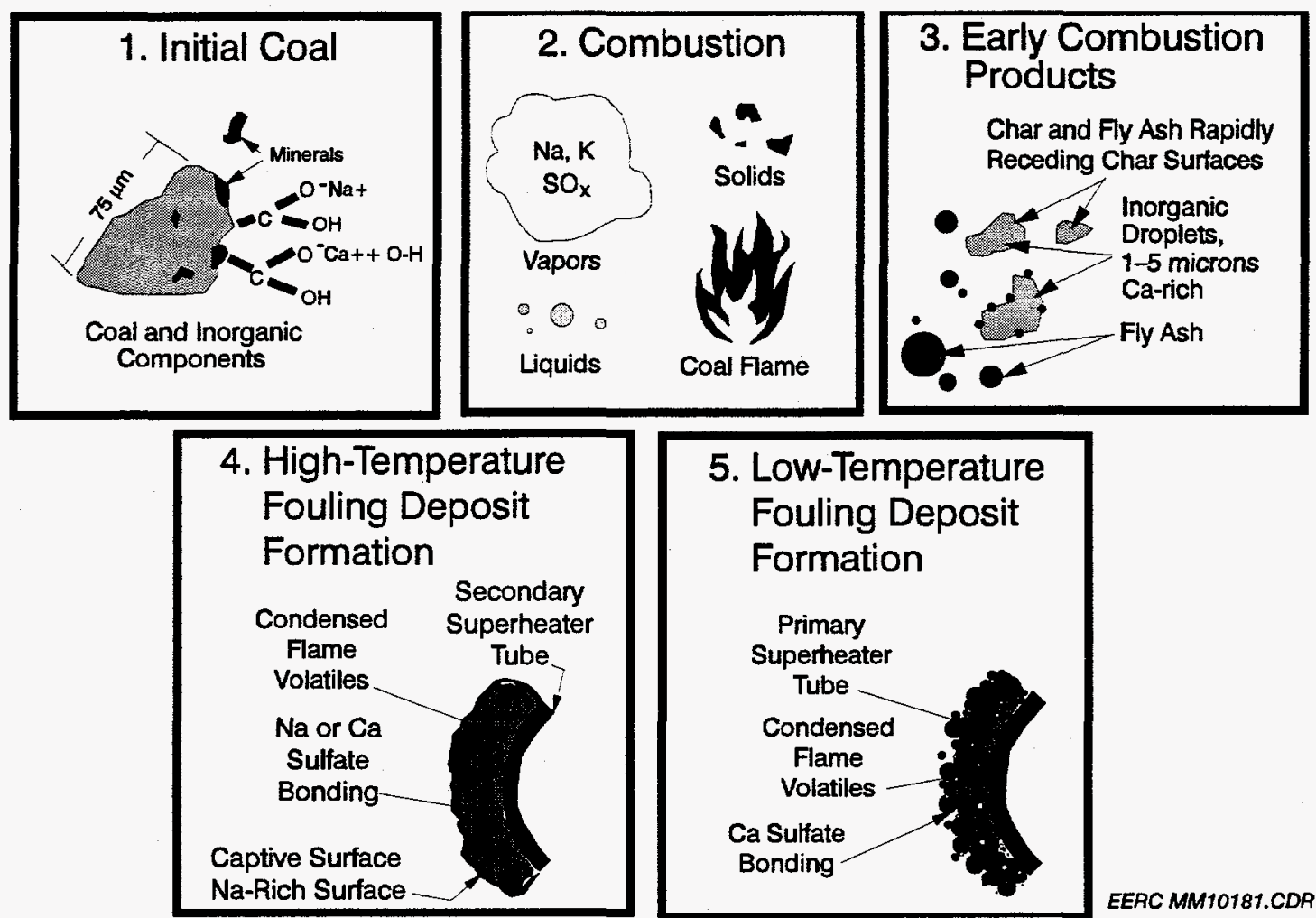

Figure 7-7. Ash formation and fouling in fluidized bed combustion.

gas velocity to its absolute temperature. In general, only a very small percentage $(<0.04 \%)$ of the ash in the $<3$-micron range that was in the flow path to a steam tube will stick to the tube.

Another common type of low-temperature deposition occurs as a powder on the downstream side of the heat exchanger tubes. These deposits cover a lot more surface area than the other types of low-temperature deposits and are the greatest detriment to heat transfer. These downstream deposits are caused by the eddy diffusion of small particles $(<10 \mu \mathrm{m})$ which adhere to the back side of the tubes. These deposits can then sinter by sulfation. The deposits on vertical tubes will frequently shed under their weight before they can sinter; however, in some cases, especially on horizontal tubes, they can become massive. In areas of turbulence, the deposits can grow at angles across the gas flow, thereby causing blockage of the gas paths. Becuase of their slower sintering rate, these deposits are susceptible to sootblowing; however, most sootblowers are installed to clean the upstream side of the tubes, which protects the downstream side from the blowing medium. The propensity of these deposits to shed can be by a relative shedding index, which is defined by the rate of deposit growth divided by the rate of strength development. The shedding index increases at lower gas velocities because larger particles can be deposited, leading to slower strength development. Like the upstream enamel deposits, the deposit fraction increases as the square of the gas velocity and inversely with the absolute temperature. Approximately, $0.4 \%$ of the ash with aerodynamic particle sizes $<10$ microns will deposit on the tube that it approaches.

Another type of upstream deposit not seen as often is composed of small crests or humps that form on either side of the tube centerline but leave the centerline clear. These ash particles 
are transported to the surface by inertial impaction; however, the particle size is such that the particles have started to flow around the tube before separating from the gas flow and impacting the surface. 
8.0

PREDICTING AGGLOMERATION IN FBCS 


\section{TABLE OF CONTENTS}

8.0 PREDICTING AGGLOMERATION IN FBCS $\ldots \ldots \ldots \ldots \ldots \ldots \ldots \ldots \ldots \ldots \ldots$ 8-1

8.1 Quantifying Melting Temperatures on a Microscale $\ldots \ldots \ldots \ldots \ldots \ldots \ldots \ldots$. $\ldots \ldots$

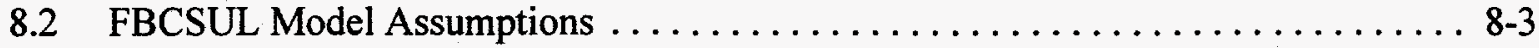

8.3 FBCSUL Applications $\ldots \ldots \ldots \ldots \ldots \ldots \ldots \ldots \ldots \ldots \ldots \ldots \ldots \ldots \ldots$

8.4 Selection of Ash for FBCSUL Analysis $\ldots \ldots \ldots \ldots \ldots \ldots \ldots \ldots \ldots \ldots \ldots . \ldots \ldots$

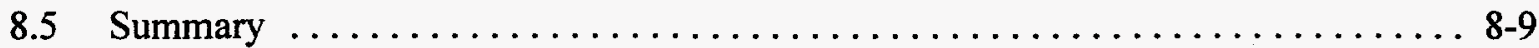

\section{LIST OF FIGURES}

8-1 Phase diagram for the alkaline sulfate system, including sodium, calcium, and magnesium 8-1

8-2 Distribution of alkali sulfate points from a Center lignite baghouse ash generated in the

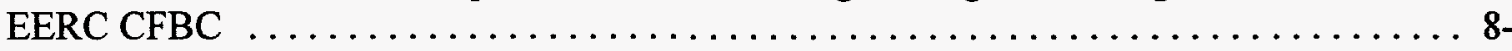

8-3 Distribution of alkali sulfate points from a fluid coke baghouse ash generated in the EERC CFBC ..................................... $8-3$

8-4 Comparison of FBCSUL output based on the alkaline components of the baghouse ash for four test coals fired on the EERC CFBC $\ldots \ldots \ldots \ldots \ldots \ldots \ldots \ldots \ldots \ldots .4$

8-5 Comparison of FBCSUL output based on all components of the baghouse ash for four test coals fired on the EERC $\mathrm{CFBC} \ldots \ldots \ldots \ldots \ldots \ldots \ldots \ldots \ldots \ldots \ldots \ldots$

8-6 Comparison of FBCSUL output based on the alkaline components of the downcomer ash for the four test coals fired on the EERC CFBC $\ldots \ldots \ldots \ldots \ldots \ldots \ldots \ldots \ldots \ldots$

8-7 Comparison of FBCSUL output based on all components of the downcomer ash for four test coals fired on the EERC CFBC $\ldots \ldots \ldots \ldots \ldots \ldots \ldots \ldots \ldots \ldots \ldots \ldots \ldots \ldots$

8-9 Impact of the ash origin on the FBCSUL output based on all the components $\ldots \ldots \ldots$ 8-9

\section{LIST OF TABLES}

8.1 Oxide Composition of Ashes Used for Test Cases $\ldots \ldots \ldots \ldots \ldots \ldots \ldots \ldots \ldots$

8.2 Composition of Ashes Used for Comparison Purposes Converted to a Sulfate System . . . 8-8 


\subsection{PREDICTING AGGLOMERATION IN FBCS}

One of the objectives of this project was to develop methods to predict the tendency for a fuel to agglomerate. There are a number of techniques that have been used previously by the EERC and other organizations, and some have been developed as a result of this project, including standard indices based on the bulk chemistry of the ash, utilizing phase diagrams to predict the amount of ash melting at a given temperature, measuring the sinter temperature of the ash, performing tests in bench-scale reactors, and performing pilot-scale test burns. The primary method developed based on the results from this program utilizes phase diagrams to predict the melting characteristics of the ash material. This method is not proven effective for determining the impacts of alternative bed materials, and bench-scale testing is recommended for these cases. Pilotscale testing is still believed to be the most reliable. This section will focus on the utilization of phase diagrams to predict the tendency for an ash to form agglomerates.

\subsection{Quantifying Melting Temperatures on a Microscale}

When performing a standard ASTM ash fusion test to determine the melting characteristics of an ash, several different temperatures are noted, such as the initial deformation temperature, softening temperature, hemispherical temperature, and fluid temperature. The accuracy of the technique is reported at $\pm 100^{\circ} \mathrm{F}$. Coal ash is very heterogeneous in nature, and each individual particle has its own characteristic melting point. This heterogeneity of melting points is the reason we first see an initial deformation where relatively few particles melt, followed by a softening where more particles melt, through the fluid temperature where all particles are melted. For determining the propensity of an ash to agglomerate, it is not important where the bulk of the ash becomes fluid, but to determine the temperature at which individual particles melt and the percentage of particles that are molten at any given temperature. The greater the number of sticky particles at a given temperature, the greater the chance of agglomerating. A program called FBCSUL has been developed to show this temperature distribution based on a particle-by-particle chemical analysis.

The temperature at which each individual particle of ash will melt is determined by its composition. This melting point can be found by examining phase diagrams for the particular system of interest. For example, Figure 8-1 presents the phase diagram for a calcium, sodium, magnesium sulfate system. From this diagram, it can be seen that a particle consisting of $100 \%$ $\mathrm{CaSO}_{4}$ will have the highest melting point of $1450^{\circ} \mathrm{C}\left(2642^{\circ} \mathrm{F}\right)$. However, when calcium, sodium, and magnesium sulfates are combined in a single ash particle, the melting point can be as low as $650^{\circ} \mathrm{C}\left(1200^{\circ} \mathrm{F}\right)$. For a given ash material generated from $\mathrm{FBC}$, a distribution of compositions will exist, with a variety of melting points. Figures 8-2 and 8-3 show the compositions of individual baghouse ash particles for Center lignite and fluid coke on the alkali sulfate phase diagram. The points plotted on these phase diagrams were determined using CCSEM analysis. The baghouse ash was collected during tests on the EERC CFBC. For the Center lignite (Figure 8-2), there is a fairly wide distribution of compositions, with a significant amount of points in the low-temperature region of the phase diagram. In contrast, the fluid coke baghouse ash has a composition dominated by high-temperature melting calcium, magnesium sulfates. 


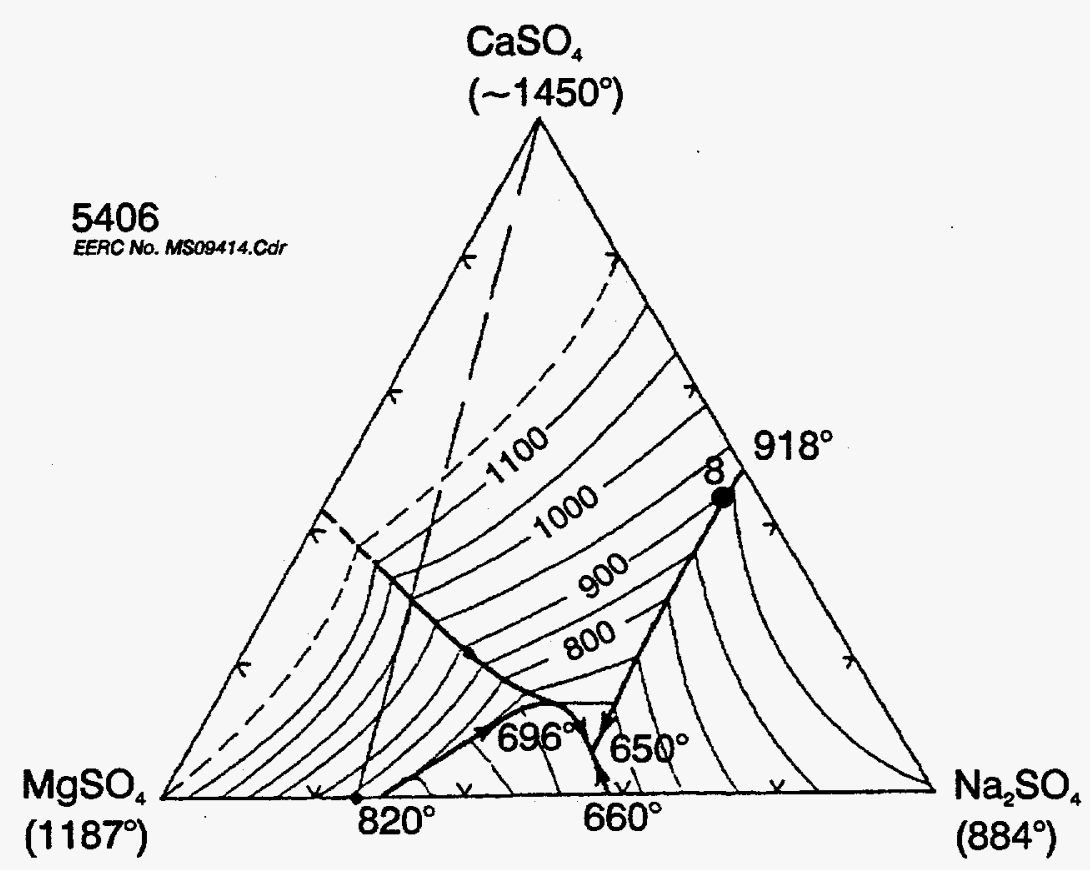

Figure 8-1. Phase diagram for the alkaline sulfate system, including sodium, calcium, and magnesium.

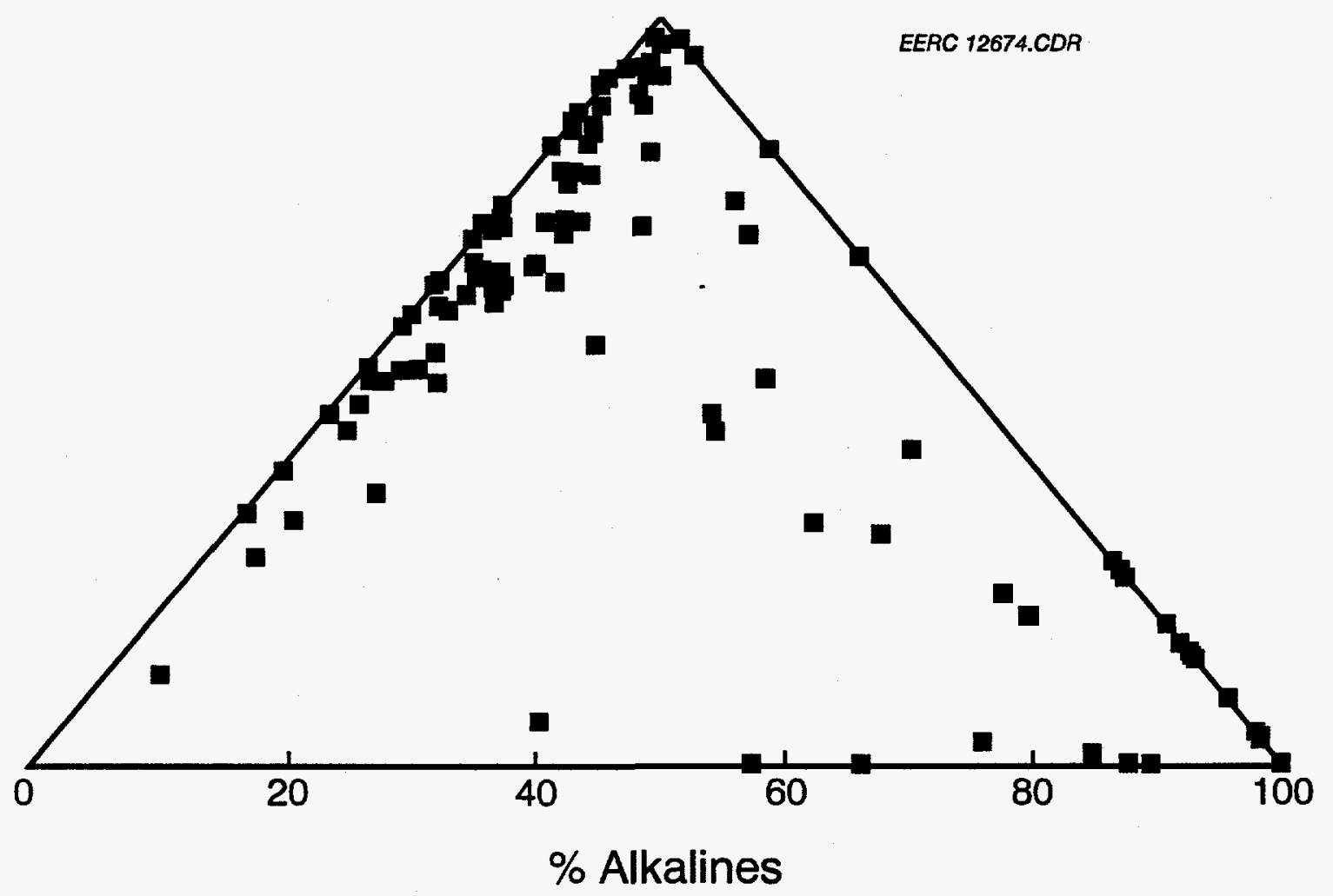

Figure 8-2. Distribution of alkali sulfate points from a Center lignite baghouse ash generated in the EERC CFBC. 


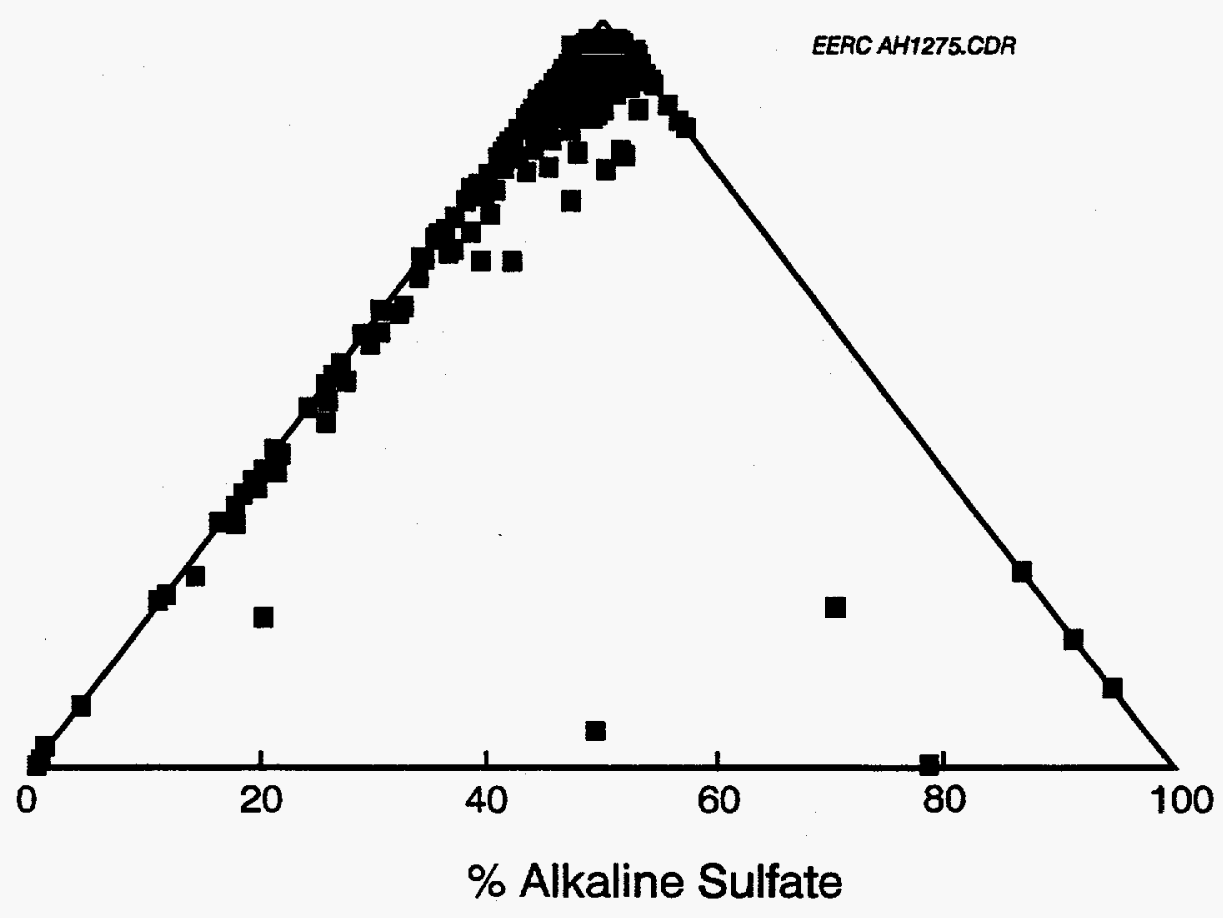

Figure 8-3. Distribution of alkali sulfate points from a fluid coke baghouse ash generated in the EERC CFBC.

A system displaying the chemical composition of Figure 8-2 would cause more ash-related problems than that in Figure 8-3 because of the larger percentage of low-melting particles. It is difficult, if not impossible, however, to quantitate these differences based on the visual examination of these phase diagrams. A program was written to take the data generated from CCSEM analysis, convert them into a phase diagram similar to those of Figures 8-2 and 8-3, and then plot those data as a cumulative percentage of particles existing in the melt phase as a function of temperature. Figure 8-4 presents such a plot for the two ashes shown in Figures 8-2 and 8-3 and includes ash from the Black Thunder subbituminous and Blacksville bituminous tests also performed on the EERC CFBC. As presented in Section 4.0, the Center lignite was the only coal that led to agglomeration problems in the EERC CFBC tests. Figure 8-4 indicates that for the Center lignite, over $35 \%$ of the alkali- based ash material would be present as a liquid phase for temperatures in the range of $1750^{\circ} \mathrm{F}$. The alkaline components of the Black Thunder and fluid coke baghouse ash did not exhibit significant amounts of liquid phase until temperatures reached approximately $2500^{\circ} \mathrm{F}$. The baghouse ash from the Blacksville coal, however, showed the highest percentage of the alkaline material melting at relatively low temperatures. This was unexpected since this coal showed no ash-related problems. In reviewing the data for this coal, it is apparent that the low melting temperatures are predicted based on a concentration of sodium in the baghouse ash. After a discussion of the assumptions used in the FBCSUL program and a reinterpretation of the data, it will become clear why the graphical presentation in Figure 8-4 seems to contradict test results.

\subsection{FBCSUL Model Assumptions}

At this point, it may be helpful to digress to the mechanics of the FBCSUL code that were used to generate these curves. The CCSEM analysis routine determines the composition of a large 


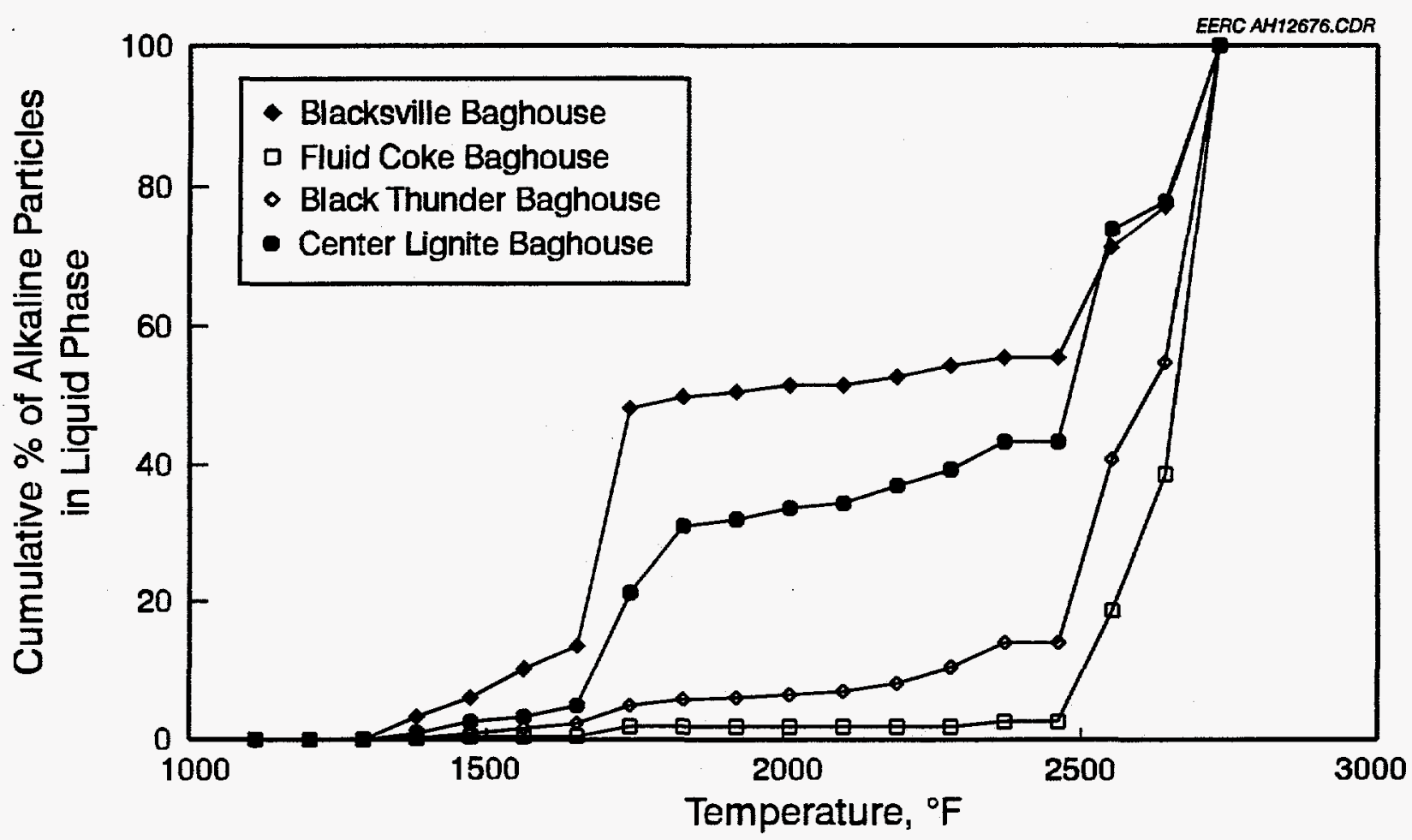

Figure 8-4. Comparison of FBCSUL output based on the alkaline components of the baghouse ash for four test coals fired on the EERC CFBC.

number (typically $>2000$ ) of random points within the ash sample. The FBCSUL program is based on the sulfate chemistry, since the silicates do not form eutectics that melt within the temperatures typical of the fluid bed. Therefore, the program looks at the analysis for each particle and determines whether the particle is alkali (calcium, sodium, or magnesium) or silicate based. Silicate-based particles are removed from further consideration. For those alkali-based particles, the program assumes that the alkalies will be fully sulfated and renormalizes the data based on $\mathrm{Na}_{2} \mathrm{SO}_{4}, \mathrm{MgSO}_{4}$, and $\mathrm{CaSO}_{4}$. The phase diagram given in Figure 8-1 has been coded into the program, so that the composition of each of the alkali sulfate points can be plotted on the ternary diagram and the temperature at which each point melts can be determined. The melting points for each point are used as the input for the cumulative percentage of material melting as a function of temperature.

FBCSUL makes several assumptions. First, it assumes that only the alkali sulfates are available to contribute to agglomeration. This is true for most systems and represents the database used for this study. High-iron systems may lead to agglomeration at higher operating temperatures and are not considered in this program. Silicate melts come into play only during process upset conditions. A more sophisticated model should include phase diagrams that represent the chemistry of all ash particles present. This would involve a much more complicated program, as it would require algorithms to determine which eutectic system was appropriate for all 2000 particles.

A second assumption made is that for those particles with small quantities of silica present, the calcium present will assimilate with the aluminosilicates before it is available to sulfate. This 
was done to take into account the mixed clays that exist in the system. The program assumes that the presence of these small amounts of silica is due to an analysis of a mixed particle, that is, the SEM beam stopped at a location where a clay was in close proximity to an alkali sulfate particle and gave a mixed analysis.

A third assumption is that all alkalies are assumed to be fully sulfated. Although the alkalies exist in the gas phase, primarily as hydroxides and chlorides with some sulfates, once they are deposited on the surface of another particle, they immediately sulfate. Also, those particles that exist as a liquid at the burning coal surface will sulfate quickly once the particle has left the localized reducing zone of the burning coal. This assumption also greatly simplifies the system, by reducing it to three well-defined components.

FBCSUL estimates the melting temperature of each sulfate particle in the system. The CCSEM analysis not only determines the chemical composition of individual particles, but also their size. Therefore, each data point contains both composition and size information, and FBCSUL adds a melting temperature to this data set. Therefore, the FBCSUL output can be plotted based on the accumulation of all alkaline particles analyzed, or curves similar to those in Figure 8-4 can be generated for each size fraction analyzed by CCSEM. This option can be a useful tool in studying mechanisms of ash-related problems.

\subsection{FBCSUL Applications}

As stated, FBCSUL only considers the alkali particles. Therefore, the cumulative distribution is based on only the alkali-based particles. The plot in Figure 8-4 represents the percentage of alkali sulfate particles that are liquid at the given temperature. It is not a plot of percentage of total particles that are liquid at a given temperature. It therefore gives a worst-case scenario, since the other points in the ash would not be expected to significantly contribute to agglomeration problem. This was done to magnify the impacts of the alkali chemistry. For example, for the data plotted in Figure 8-4, FBCSUL used only $8.8 \%$ of the points for the Blacksville ash, $36.4 \%$ for Black Thunder, $43.5 \%$ for the Center lignite, and $62.2 \%$ for the fluid coke. When interpreting the data, it is beneficial to generate plots based on the alkali chemistry alone, such as Figure 8-4, but plots based on the percentage of total points analyzed are required to provide the true ranking of agglomeration potential. Figure 8-5 plots the same data as Figure 8-4, but the cumulative percentage is based on all points analyzed. From this plot, it is evident that the Center lignite would be expected to present the most significant ash-related problems. It also points out that the Blacksville ash in reality has a low percentage of low melting points and, therefore, a low propensity to agglomerate. It should also be remembered, however, that for circulating fluidized-bed combustors, there is a very high mass flux, and even a very small percentage of particles represents a significant quantity of sticky particles.

As a comparison, a downcomer ash sample from the same four fuels displayed in Figures 8-2 through 8-5 was analyzed. Figure 8-6 presents the cumulative percentage of particles in the liquid phase, based on only the alkaline particles in the downcomer ash. The four fuels are ranked in the order that is expected. Similar trends are seen between the baghouse and downcomer samples with regard to the temperatures at which significant increases in liquid particles appear. When the data are presented based on all particles analyzed by CCSEM (Figure 8-7), the data appear similar to those generated from the baghouse ash, presented in Figure 8-5. 


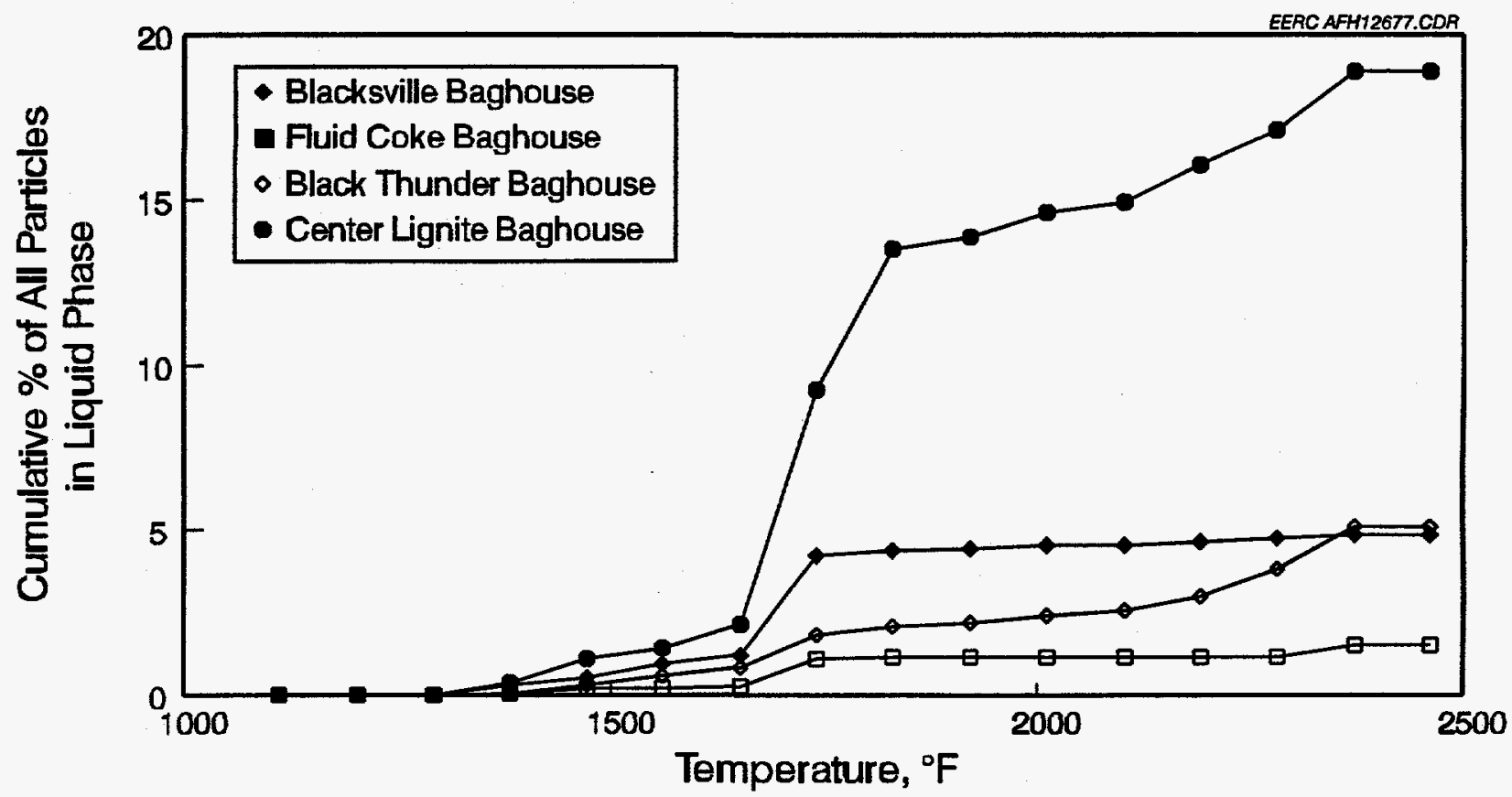

Figure 8-5. Comparison of FBCSUL output based on all components of the baghouse ash for four test coals fired on the EERC CFBC.

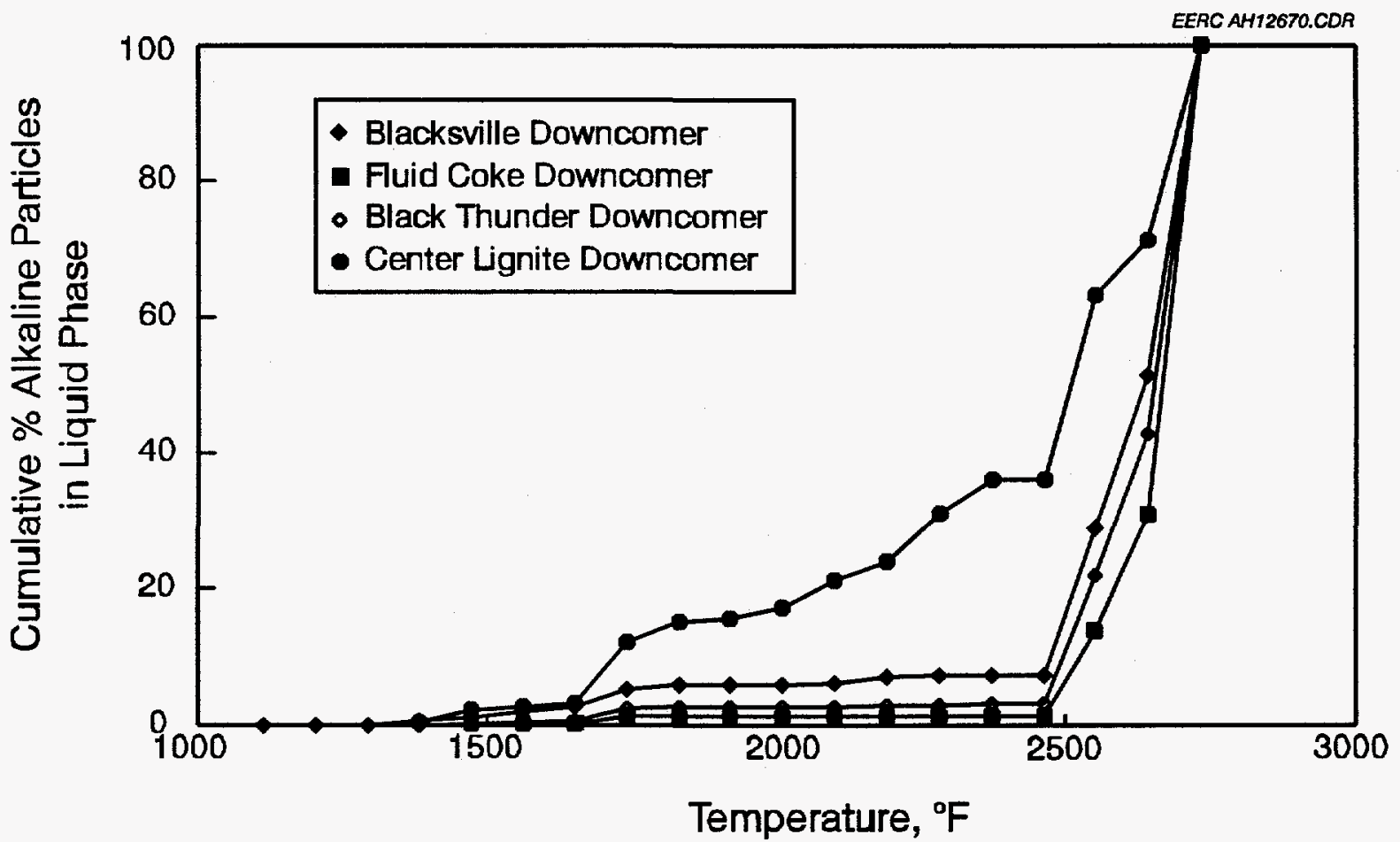

Figure 8-6. Comparison of FBCSUL output based on the alkaline components of the downcomer ash for the four test coals fired on the EERC CFBC. 


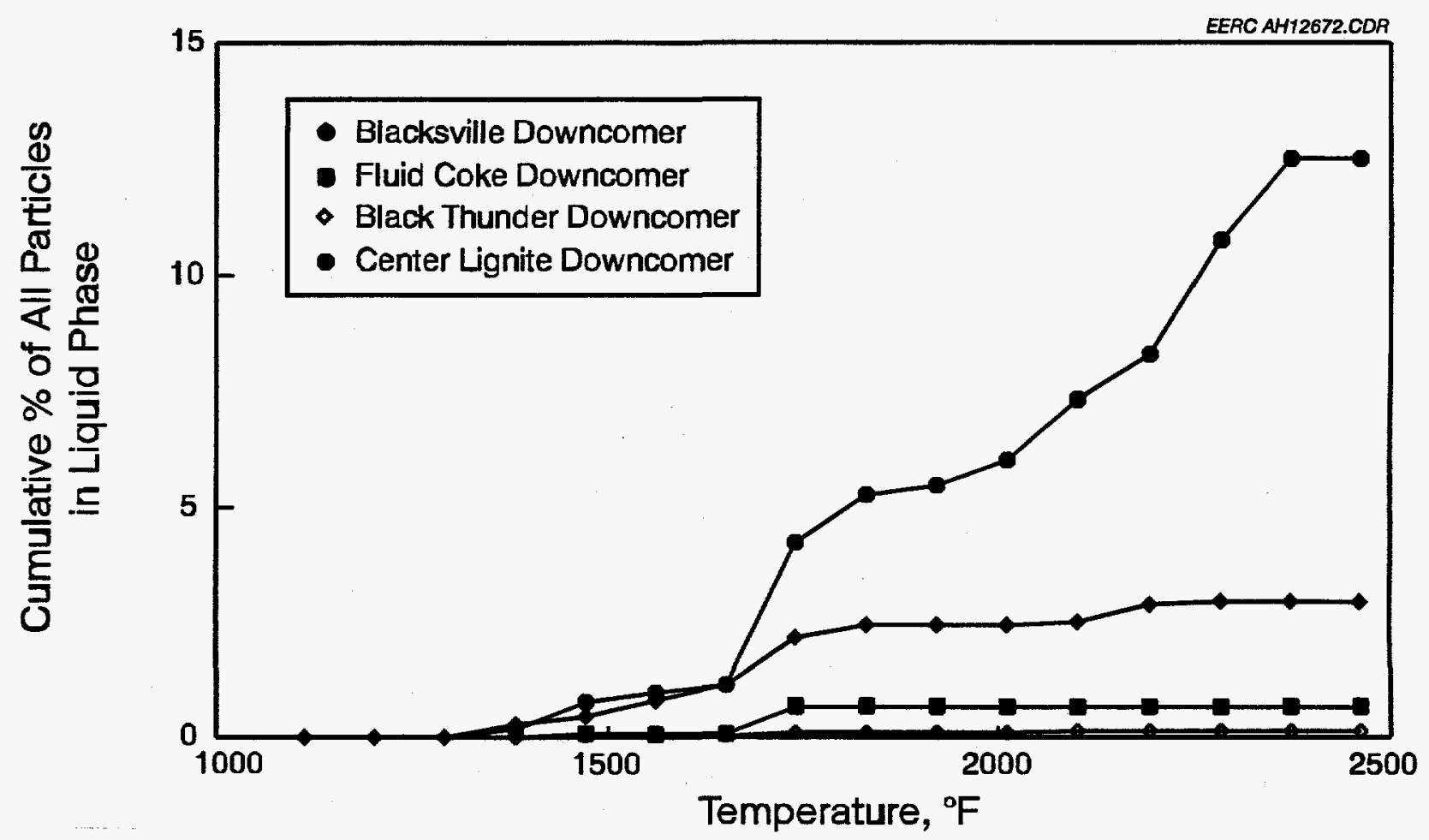

Figure 8-7. Comparison of FBCSUL output based on all components of the downcomer ash for four test coals fired on the EERC CFBC.

The plotting convention used in Figures 8-4 and 8-6, that is, using only the alkali-based points in determining the cumulative distribution, reveals information that can be used in selecting the design temperature for the FBC. For example, for Center lignite and Blacksville, there is a relatively low percentage of particles melting below about $1700^{\circ} \mathrm{F}$ and a very sharp rise over the next 100 degrees. The other two fuels showed only a gradual increase up to a very high temperature. Therefore, this type of data presentation will provide the user with temperature design data.

\subsection{Selection of Ash for FBCSUL Analysis}

FBCSUL was constructed assuming that the input data set would be generated using an ash sample created under FBC-like conditions. This could be from a pilot-scale FBC similar to the data used to generate Figures 8-2 through 8-7 or from a bench-scale reactor similar to that developed during this program. This specification was required since it is important that the interaction of the sorbent with the coal ash and similar temperatures to a real fluid bed be incorporated in the model. As a comparison, Figure 8-8 plots the melting behavior of lignite ash generated using a lowtemperature ashing (LTA) procedure, and fly ash from cyclone-firing of the coal and from the baghouse of the EERC CFBC. The LTA shows that virtually all of the alkaline particles will become liquid at approximately $1700^{\circ} \mathrm{F}$, while the fly ash shows only a low percentage of low melting points. The LTA also shows a sharp increase in low melting points at approximately $1350^{\circ} \mathrm{F}$. These differences imply that the inorganics in the coal undergo different transformations, depending upon the temperature and atmosphere under which they are created. A comparison of 
the baghouse ash with ASTM ash is presented as Table 8-1 to demonstrate that point. Significant differences exist between the two ashes for each coal. This impact is also seen in Table 8-2, which shows only the alkali sulfates for each case. Also shown in Table 8-2 is the melting point based on the bulk alkali chemistry. These high temperatures provide another indication of the importance of using a particle-by-particle analysis rather than bulk chemistry.

TABLE 8.1

Oxide Composition of Ashes Used for Test Cases

\begin{tabular}{lcrrrrrrr}
\hline & \multicolumn{2}{c}{ Blacksville } & \multicolumn{2}{c}{ Fluid Coke } & \multicolumn{2}{c}{ Black Thunder } & \multicolumn{2}{c}{ Center Lignite } \\
& \multicolumn{1}{c}{$\mathrm{BH}^{1}$} & \multicolumn{1}{c}{ ASTM } & \multicolumn{1}{c}{$\mathrm{BH}$} & ASTM & \multicolumn{1}{c}{$\mathrm{BH}$} & ASTM & \multicolumn{1}{c}{ BH } & ASTM \\
\hline $\mathrm{CaO}$ & 6.4 & 5.6 & 63.0 & 2.2 & 36.3 & 24.4 & 9.7 & 22.6 \\
$\mathrm{MgO}$ & 1.2 & 1.2 & 2.6 & 1.3 & 4.8 & 7.9 & 2.3 & 10.2 \\
$\mathrm{Na}_{2} \mathrm{O}$ & 1.1 & 0.7 & 0.4 & 0.2 & 0.3 & 0.5 & 1.1 & 3.7 \\
$\mathrm{SiO}_{2}$ & 47.7 & 43.6 & 2.7 & 42.2 & 24.7 & 28.5 & 72.8 & 14.5 \\
$\mathrm{Al}_{2} \mathrm{O}_{3}$ & 21.7 & 22.7 & 0.6 & 24.0 & 16.6 & 16.4 & 6.5 & 9.7 \\
$\mathrm{Fe}_{2} \mathrm{O}_{3}$ & 14.4 & 16.6 & 0.5 & 16.6 & 4.1 & 6.4 & 2.3 & 10.1 \\
$\mathrm{TiO}_{2}$ & 0.6 & 0.7 & 0.0 & 3.1 & 0.0 & 1.4 & 0.5 & 0.3 \\
$\mathrm{P}_{2} \mathrm{O}_{5}$ & 0.3 & 0.4 & 0.0 & 0.0 & 0.0 & 1.3 & 0.2 & 0.7 \\
$\mathrm{~K}_{2} \mathrm{O}$ & 1.5 & 1.7 & 0.2 & 1.8 & 0.53 & 0.9 & 0.5 & 0.4 \\
$\mathrm{SO}_{3}$ & 5.0 & 6.8 & 28.6 & 1.9 & 12.8 & 12.4 & 2.7 & 21.9 \\
\hline
\end{tabular}

BH - Ash taken from the baghouse from EERC CFBC pilot plant tests.

2 ASTM - Standard ASTM ash analysis of the coal.

TABLE 8.2

Composition of Ashes Used for Comparison Purposes Converted to a Sulfate System

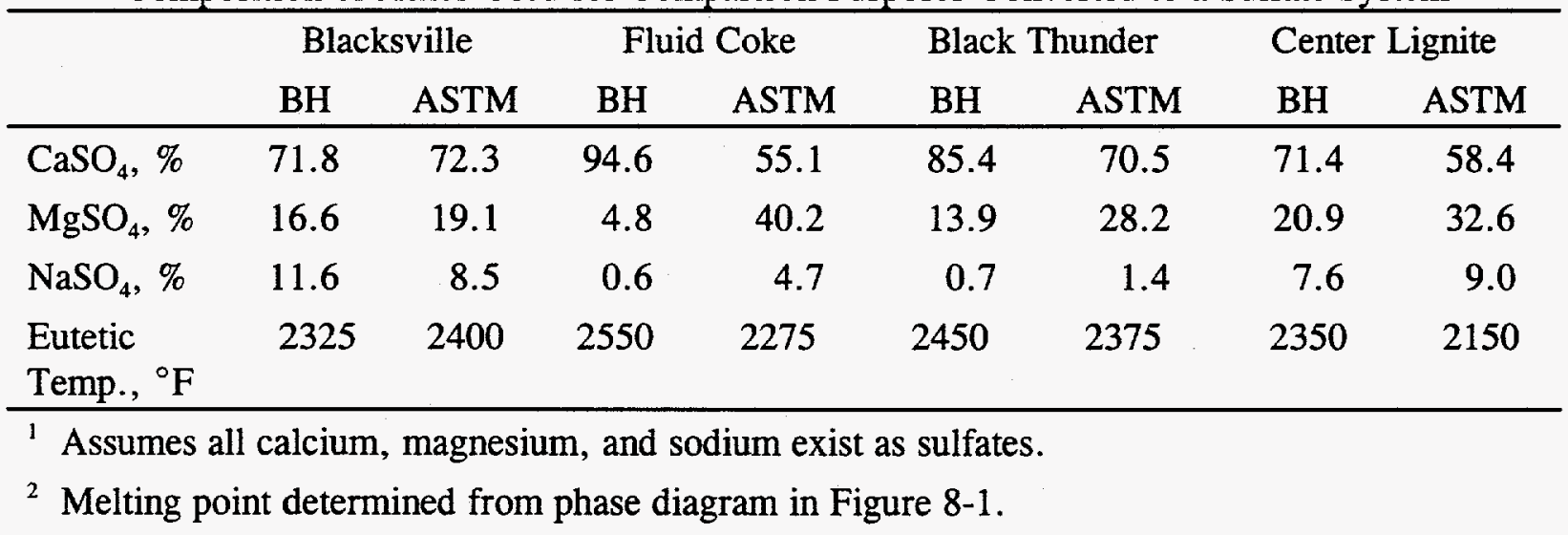


The data from Figure 8-8 are replotted as Figure 8-9, based on the cumulative percentage of all particles analyzed by the CCSEM routine. These data show a significantly different trend than Figure 8-8. Based on the percentage of all particles in the system, the analysis of the CFBCgenerated ash shows a much higher percentage of low melting particles and implies that more serious ash-related problems can be expected. It is unclear at this time why the CCSEM analysis of the LTA identified such a low percentage of alkaline-based points. Based on the data in Figure 88 , an argument could be made that the LTA is more sensitive to the contribution of the sodium to the eutectic system and is, therefore, a more conservative predictor of agglomeration than using the FBC-generated ash. However, the data presented in Figure 8-9 indicate that using LTA may underpredict the agglomeration propensity. A larger database is needed, however, to draw a firm conclusion.

\subsection{Summary}

A model was developed to predict the tendency for the ashes to agglomerate in the FBC. This model, called FBCSUL, is based on the chemistry of each individual ash particle. The model delivers several different levels of information. The melting characteristics of the alkaline components of the ash identify critical temperatures where ash-related problems may become severe. The percentage of total ash melting below a given temperature can be used to effectively rank the agglomerating potential of different fuels. This technique should prove valuable in determining the impact of additives on changing the overall bed chemistry by incorporating the alkalies, especially sodium, into higher melting phases. The model is the most accurate when ash generated from FBC-like conditions is used, but may also have some limited utility with ash from other sources, such as ASTM ashing.

Other predictive techniques were also examined. Indices based on bulk chemistry have little value in predicting agglomerating tendencies. An exception would be the convention of ranking agglomerating tendencies based on the water-soluble alkali content of the fuel ash. Sintering is another technique that can be used. This technique has been demonstrated by others to provide a reasonable approximation of sintering temperature, which can be used as an indicator of the potential for the agglomeration to occur. This technique is of the most value when performed on an ash generated in an FBC-like atmosphere and accounts for the interaction of the sorbent with the coal-derived ash. Bench- and pilot-scale tests are still found to be the most accurate predictors of agglomeration. 


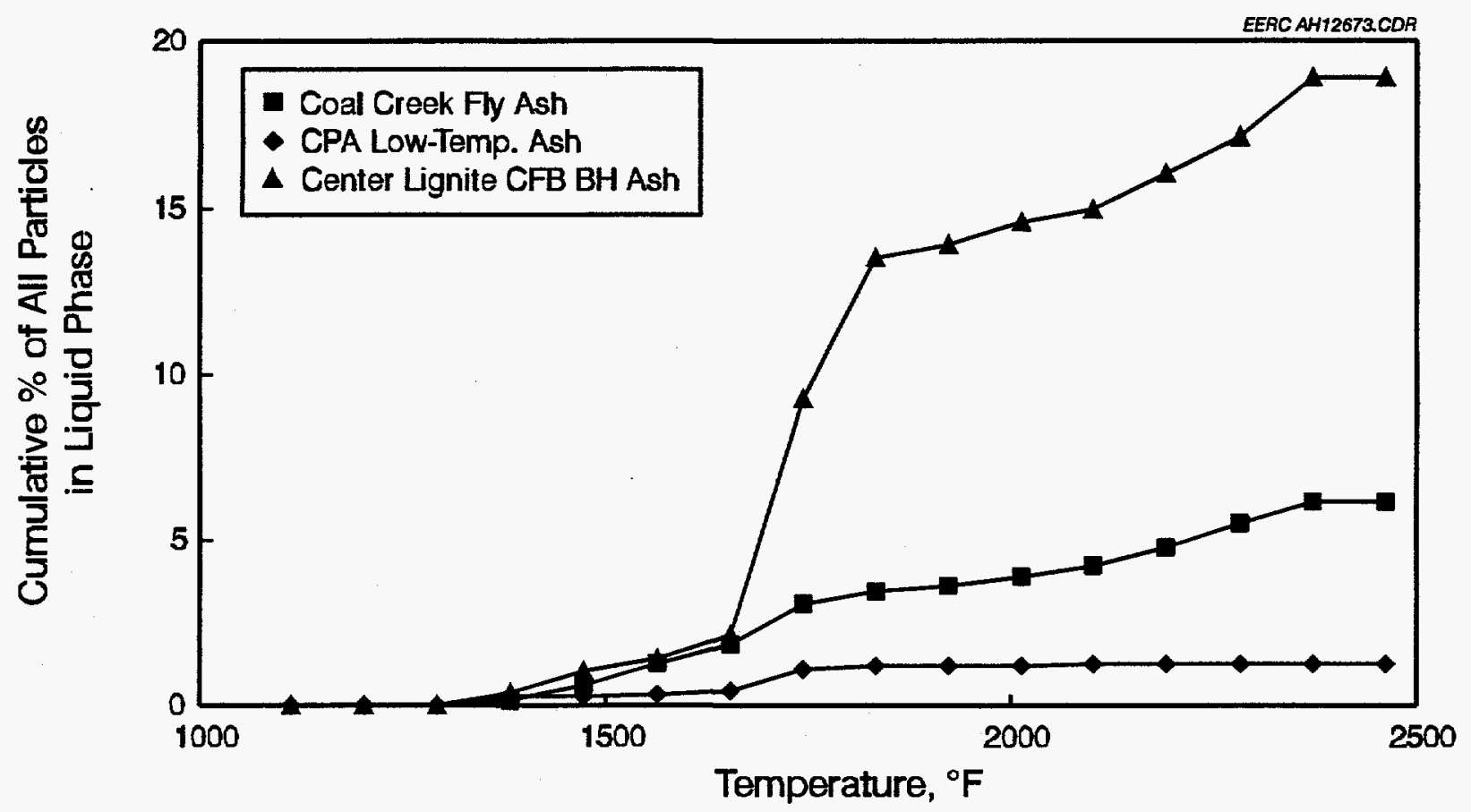

Figure 8-9. Impact of the ash origin on the FBCSUL output based on all the components. 


$$
9.0
$$

PREDICTING DEPOSITION IN FBCS 
VARIABLE DEFINITION LIST $\ldots \ldots \ldots \ldots \ldots \ldots \ldots \ldots \ldots \ldots \ldots \ldots \ldots$ 9-i

$9.0 \quad$ PREDICTING DEPOSITION IN FBCS $\ldots \ldots \ldots \ldots \ldots \ldots \ldots \ldots \ldots . \ldots \ldots$

9.1 Fluidized-Bed Combustion Deposition Model . . . . . . . . . . . . 9-1

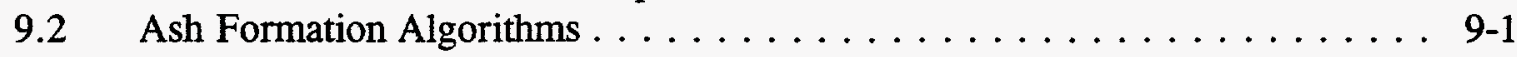

9.3 Ash Formation Results . . . . . . . . . . . . . . . . . 9-2

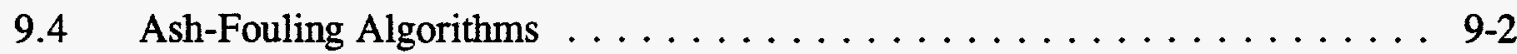

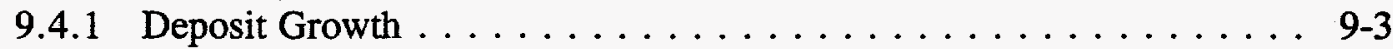

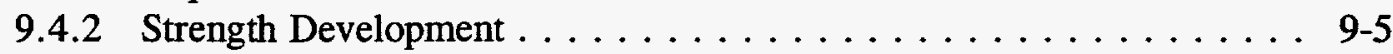

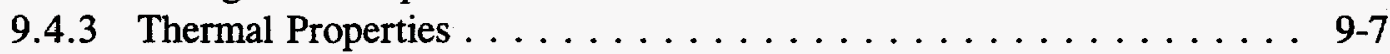

9.4.4 Deposit Removal . . . . . . . . . . . . . . . . 9-8

9.5 Fouling Algorithms Results $\ldots \ldots \ldots \ldots \ldots \ldots \ldots \ldots$ 9.9

\section{LIST OF FIGURES}

9-1 Comparison of measured, predicted, sorbent, and original coal components for ash collected in a cyclone $\ldots \ldots \ldots \ldots \ldots \ldots \ldots \ldots \ldots \ldots \ldots \ldots \ldots \ldots \ldots \ldots .2$

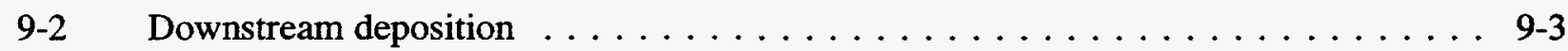

9-3 Components of the deposit growth model $\ldots \ldots \ldots \ldots \ldots \ldots \ldots \ldots$

9-4 Strength development curve $\ldots \ldots \ldots \ldots \ldots \ldots \ldots \ldots \ldots \ldots \ldots$ 9-7

9-5 Heat transfer through deposit $\ldots \ldots \ldots \ldots \ldots \ldots \ldots \ldots \ldots \ldots \ldots \ldots \ldots .9 \ldots \ldots$

9-6 Comparison of upstream and downstream deposit strengths of a Beulah lignite with limestone sorbent added and a Beulah lignite with no sorbent added $\ldots \ldots \ldots$. . $9-10$

9-7 Comparison of upstream and downstream deposit masses for a Beulah lignite fired with and without a limestone sorbent $\ldots \ldots \ldots \ldots \ldots \ldots \ldots \ldots . \ldots \ldots$ 9-11

9-8 Comparison of downstream deposit strength for three coals with a sorbent additive using the Heskett boiler configuration . . . . . . . . . . . . . . 9-12

9-9. Comparison of sootblower effectiveness for Beulah lignite using the Heskett boiler configuration 


\section{VARIABLE DEFINITION LIST}

$\mathrm{A}_{\mathrm{d}}=$ Total cross-sectional area available for ash deposition, $\mathrm{ft}^{2}$

$\mathrm{A}_{\mathrm{t}}=$ Cross-sectional area of the convective pass, $\mathrm{ft}^{2}$

$\mathrm{C}_{\text {sulf }}=$ Sulfate constant

$\mathrm{D}_{\mathrm{p}} \quad=$ Particle diameter, microns

$\mathrm{DP}=$ Deposit potential mass of ash that sticks to the tube, $\mathrm{lb}$

$\mathrm{DR}_{\mathrm{t}}=$ Low-temperature deposition rate, $\mathrm{lb} /\left(\mathrm{ft}^{2} \mathrm{hr}\right)$

$\mathrm{DR}_{\mathrm{u}}=$ Upstream deposition rate, $\mathrm{lb} /\left(\mathrm{ft}^{2} \mathrm{hr}\right)$

$\mathrm{h}_{\text {conv }}=$ Average convection coefficient, $\mathrm{Btu} /\left(\mathrm{ft}^{2} \mathrm{hr} \cdot{ }^{\circ} \mathrm{F}\right)$

$\mathrm{h}_{\mathrm{g}}=$ Heat-transfer coefficient of the gas, $\mathrm{Btu} /\left(\mathrm{ft}^{2} \mathrm{hr} \cdot{ }^{\circ} \mathrm{F}\right)$

$\mathrm{h}_{\mathrm{st}}=$ Heat-transfer coefficient of the steam, Btu/( $\left.\mathrm{ft}^{2} \mathrm{hr} \cdot{ }^{\circ} \mathrm{F}\right)$

IEF = Inertial impaction subfunction-fraction of ash that will strike the tube

$\mathrm{K}_{\text {down }}=$ Average downstream deposit thermal conductivity

$\mathrm{K}_{\mathrm{dn}}=$ Thermal conductivity of deposit layer, $\mathrm{Btu} /\left(\mathrm{ft}^{2} \mathrm{hr} \cdot{ }^{\circ} \mathrm{F}\right)$

$\mathrm{K}_{\mathrm{t}}=$ Thermal conductivity of tube, Btu $\left(\mathrm{ft}^{2} \mathrm{hr} \cdot{ }^{\circ} \mathrm{F}\right)$

$\mathrm{K}_{\mathrm{up}}=$ Average upstream deposit thermal conductivity

$\mathrm{L}=$ Unit length of $1 \mathrm{ft}$

$\mathrm{M}_{\text {ash }}=$ Total ash, $\mathrm{lb} / \mathrm{hr}$

$\mathrm{M}_{\text {dep }}=$ Total deposit mass

$\mathrm{M}_{\mathrm{L}} \quad=\quad$ Deposit layer mass

$\mathrm{M}_{\mathrm{p}} \quad=\quad$ Mass percent for a specific particle size

$\mathrm{PCF}_{1}=$ PC Sulfate Factor 1

$\mathrm{PCF}_{2}=$ PC Sulfate Factor 2

$\mathrm{q}=$ Heat-transfer rate, Btu/hr

$\mathrm{q}^{\prime \prime}$ cond $=$ Conductive heat-transfer rate

$\mathrm{q}_{\text {conv }}=$ Forced convection heat-transfer rate

$\operatorname{Rad}_{\mathrm{ds}}=$ Outer deposit radius

$\operatorname{Rad}_{\text {max }}=$ Maximum radius of ellipse, in.

$\operatorname{Rad}_{\text {min }}=$ Minimum radius of ellipse, in.

$\operatorname{Rad}_{\mathrm{t}}=$ Outside radius of tube, $\mathrm{ft}$

$\operatorname{Rad}_{t_{i}}^{0}=$ Inside radius of tube, $\mathrm{ft}$

$\mathrm{R}_{\mathrm{dn}}=$ Deposit layer radius $\mathrm{n}, \mathrm{ft}$

$\mathrm{R}_{\mathrm{dn}-1}=$ Next deposit layer radius $\mathrm{n}-1, \mathrm{ft}$

$\mathrm{R}_{\mathrm{dt}}=$ Total deposit radius

SF $=$ Cumulative sticking fraction, 0 to 1

Sil $\quad=$ Silicate variable

$\mathrm{S}_{\mathrm{rc}} \quad=$ Silicate reference constant

$\mathrm{Str}_{\text {depavg }}=$ Average deposit strength

$\mathrm{Str}_{\text {depL }}=$ Strength of individual deposit layer

$\mathrm{Str}_{\text {sil }}=$ Silicate strength

$\mathrm{Str}_{\text {sulf }}=$ Sulfate strength

$\mathrm{T}_{\mathrm{g}}=$ Gas temperature stream, $\mathrm{R}$

$\mathrm{T}_{\text {gas }}=$ Temperature of the gas stream, ${ }^{\circ} \mathrm{F}$

$\mathrm{T}_{\mathrm{dn}}=$ Deposit layer temperature, ${ }^{\circ} \mathrm{F}$

$\mathrm{T}_{\mathrm{dn}-1}=$ Next deposit layer temperature, ${ }^{\circ} \mathrm{F}$

$\mathrm{T}_{\text {douter }}=$ Temperature of outermost deposit layer 
$\mathrm{T}_{\text {steam }}=$ Temperature of the steam, ${ }^{\circ} \mathrm{F}$

$\mathrm{V}_{\mathrm{g}} \quad=$ Gas velocity, $\mathrm{ft} / \mathrm{s}$

$\alpha=$ Angle factor

$\delta=$ Potential deposition mass fraction

$\mu_{\mathrm{p}} \quad=\quad$ Particle viscosity, poise 


\subsection{PREDICTING DEPOSITION IN FBCS}

\subsection{Fluidized-Bed Combustion Deposition Model}

The Fluidized-Bed Combustion Deposition Model (FBCDEP) is a user-friendly FBC performance software package that uses information derived from advanced coal analysis methods combined with general boiler information to predict the combustion performance of a sorbent and coal. The FBCDEP program is made up of two major computer modules. The first module, ash formation algorithms, predicts the particle-size and composition distribution (PSCD) of the entrained ash reaching the convective pass of a FBC. The second module, ash fouling algorithms, predicts the ash deposition and strength development potentials of the ash, thermal resistance due to the deposition on the heat-exchange tubes, and the effectiveness of sootblowers to remove the deposits. Both models are based on theory and a combination of laboratory-, pilot-, and full-scale test data. All outputs from the FBCDEP model are on a relative basis and are intended to be used for comparative purposes only.

\subsection{Ash Formation Algorithms}

The entrained ash PSCD is predicted from the distribution of inorganics in the coal. CCSEM (Zygarlicke and others, 1990), XRF, and ultimate analysis are used to characterize the coal. The CCSEM analysis is also combined with a locked/liberated particle analysis (to determine if the individual mineral grains are located within a coal matrix or are free mineral grains) and ZAF data reduction of the compositions. The ZAF data reduction produces compositions free of the effects of atomic number (Z), x-ray absorption (A), and x-ray fluorescence (F). A mass balance is compiled on the coal by comparing the CCSEM and XRF data. The resultant balance provides the compositions of the minerals with their associations to the coal, organically associated constituents, and submicron particles. The minerals are divided into two data sets: those locked within a coal particle and those liberated from the coal matrix. The locked minerals are coalesced, on a frequency basis, in a random fashion with other mineral and submicron particles as well as those organically associated constituents that are expected to condense during the combustion of a coal particle. The coalescence produces intermediate, locked fly ash particles. The liberated minerals do not undergo a coalescence step. Both the intermediate, locked particles and liberated minerals are then reacted with those constituents which stay in the vapor phase during the early stages of combustion. During the coalescence and vapor nucleation steps, the formation of submicron fly ash is predicted. After these steps are completed, three different data sets are formed: locked fly ash, liberated fly ash, and submicron fly ash particles. The three data sets are characterized and combined on a mass basis, giving a distribution of the ash composition as a function of size.

The ash originating from the sorbent is assumed to have the same particle-size distribution as the ash originating from the coal. The amount of sorbent ash added to the coal ash is dependent upon the sorbent feed rate and coal feed rate. Using an XRF analysis of the sorbent, a mass balance is done on the sorbent ash and coal ash. 


\subsection{Ash Formation Results}

Figure 9-1 compares the initial inorganic components of Pittsburgh No. 8 coal, limestone, and the predicted results from the ash formation algorithms with the experimentally measured results. The cyclone data are from a test performed on the EERC CFB, using this fuel and limestone. The predicted results compare well with the experimentally measured results.

\subsection{Ash-Fouling Algorithms}

A series of ash deposition algorithms have been developed at the EERC over the last five years. These algorithms are in various forms and at various levels of sophistication. The codes have been combined into a single ash deposition algorithm for use in all aspects of ash fouling. The combined algorithm will utilize the ash formation algorithm discussed in Section 9.5. The overall structure of the algorithm is not new and will not be discussed in detail here. The general algorithm combines four fundamental principles of deposition: 1) deposit growth, 2) strength development, 3) thermal properties, and 4) deposit removal. Each of these principles is discussed below with respect to its implementation in the code.

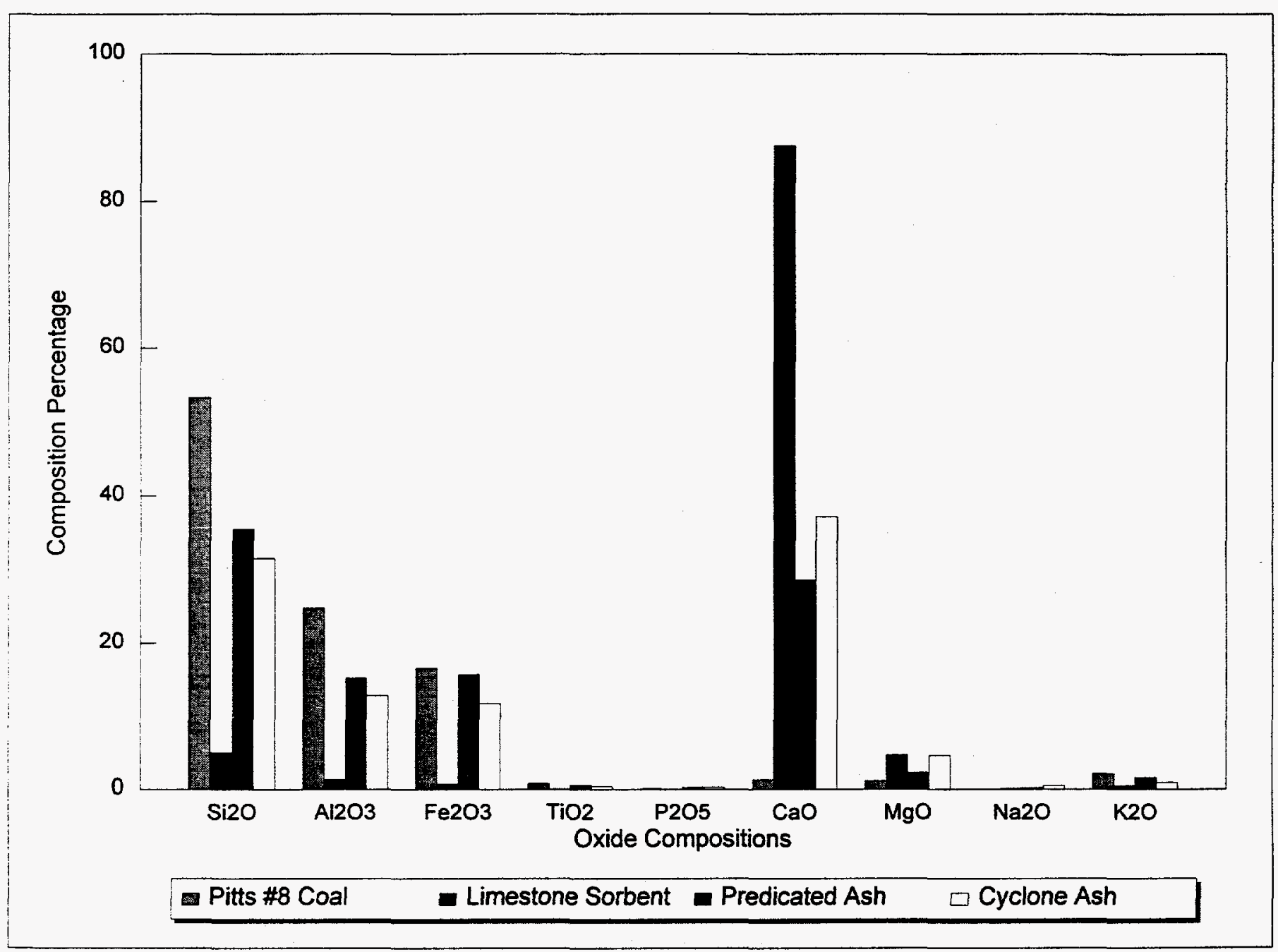

Figure 9-1. Comparison of measured, predicted, sorbent, and original coal components for ash collected in a cyclone. 


\subsubsection{Deposit Growth}

The first function of the deposit growth submodel is to organize the ash by size into three ash categories. The code will utilize the data produced from the ash formation algorithms as discussed later. The PSCD of the ash is divided into six size and seven composition bins, for a total of 42 bins of ash particles. The first ash category includes ash particles less than 5 microns in diameter, which makes up the initial layer. All ash particles less than 10 microns are included in the second category used in modeling the downstream deposit. Downstream deposits are formed by impaction from the recirculation eddies passing around the heatexchange tubes. As the gas stream passes around the tube, those particles that do not inertially impact (generally less than 10 microns) get caught in the recirculation eddies of the gas stream and are impacted into the downstream side of the tube surface, as shown in Figure 9-2. The last ash category forming the upstream deposit includes all the size and composition bins.

As discussed previously, the three primary modes of fouling deposit growth are inertial and eddy impaction; vapor-phase and small-particle diffusion; and thermophoresis/ electrophoresis. The inner layer, formed by small-particle diffusion and thermophoretic/electrophoretic forces, comprises primarily vapors and particles less than 5 microns that traverse through the boundary layer surrounding the tube and deposit. Which particles actually deposit depends upon the flow characteristics around the heat-exchange tubes. At higher temperatures and faster gas velocities, the inner layer is enriched in vapor-phase species and remains loosely bound, while at lower temperatures and lower velocities, the enrichment tends to shift to particles in the less-than-5-micron range. In both cases, the inner layer plays a role in the eventual formation of massive upstream deposits.

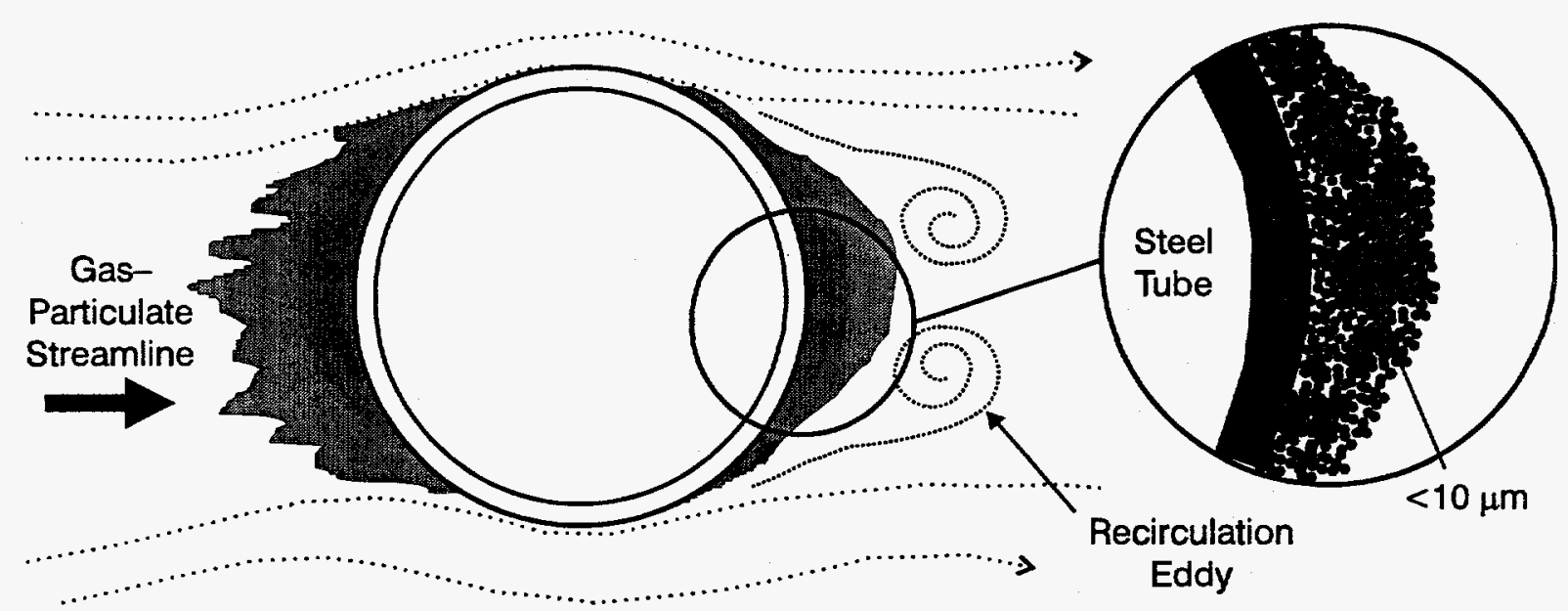

Figure 9-2. Downstream deposition. 
Both the downstream and inner layer deposition rates (DR), where $t$ is the type of deposit layer-downstream $\left(_{d}\right.$ ) or initial $(G)$, are calculated from the following equation:

$$
D R_{t}=\frac{V_{g}^{2}}{T_{g}} \times R_{r} \times M_{a s h} \times \frac{\delta}{A_{d}}
$$

Potential deposition mass is the fraction of total mass in the respective ash categories described previously for initial and downstream deposition. Total ash is the total mass of ash passing through the convective pass.

The massive upstream deposits form primarily by inertial impaction onto the surface of the deposit. The deposit surface can be captive or noncaptive. The larger particles become separated from the gas stream as it flows around the tubes. The particles impact the surface and either stick or deflect off, depending upon their sticking ability and the captive surface of the tube. As massive deposits grow, the surface temperature of the deposit increases, developing a highly captive surface that will capture most of the impacting particles. As the deposit grows, it commonly becomes more aerodynamic, thus minimizing the amount of ash that impacts the surface.

The upstream deposition function is separated into three subfunctions, as shown in Figure 9-3. The sticking fraction subfunction determines the deposit potential, which is the fraction of the total ash in the path of the heat-transfer surface that sticks. A cutoff particle viscosity is calculated by using the values from the inertial impaction subfunction (IEF). If the particle viscosity is less than the cutoff viscosity, Equation 2, that particle is added to the sticking fraction.

$$
\mathrm{DP}=\alpha \times \frac{\mathrm{M}_{\mathrm{p}}}{100} \times \mathrm{IEF}
$$

The impact efficiency value is a combination of two values: the impact efficiency strike (IES) and the impact efficiency velocity (IEV). The IES value $(0$ to 1$)$ is the fraction of ash that will strike the tube, and the IEV value $(0$ to 1$)$ is used to determine whether the particle has sufficient kinetic energy to rebound off or stick to the tube surface. The upstream deposition function goes through each ash particle-size fraction using the gas stream temperature and determines the impaction efficiency value for each size fraction and the cutoff particle viscosity. Summing all of the size bins, a cumulative sticking fraction (SF) value (0 to 1$)$ can be determined. The cumulative sticking fraction is then used in Equation 3 to determine the upstream deposition rate.

$$
\mathrm{DR}_{\mathrm{u}}=\frac{\mathrm{M}_{\text {ash }}}{\mathrm{A}_{\mathrm{b}}} \times \mathrm{SF} \times 2 \times \mathrm{Rad}_{\mathrm{t}_{\mathrm{o}}}
$$




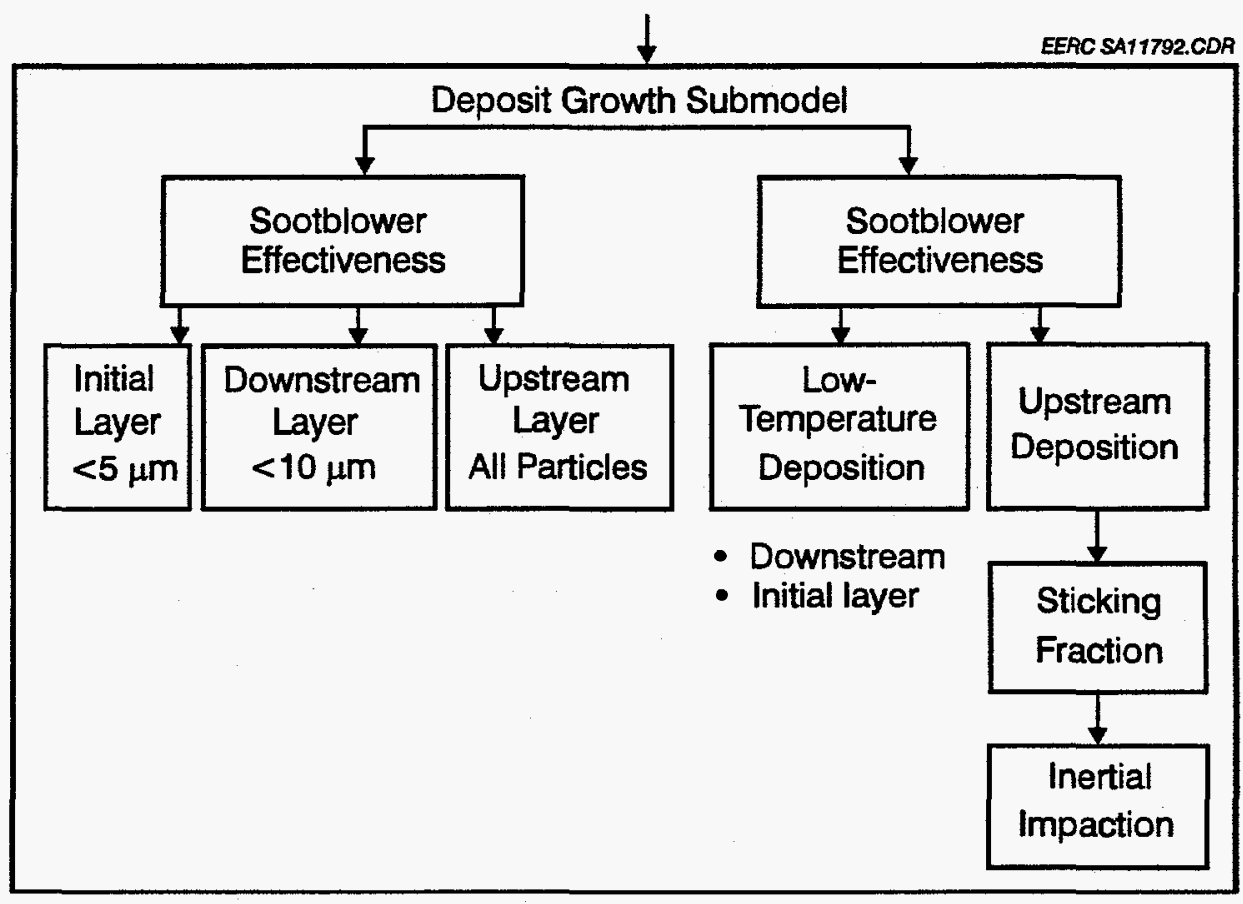

Figure 9-3. Components of the deposit growth model.

\subsubsection{Strength Development}

Strength development is generally the result of one of two sintering mechanisms: silicateor sulfate-based. The low viscosities necessary for silicate-based sintering are commonly attributed to higher temperatures and lower-melting-point phases such as sodium aluminosilicates. Some of the reduction in melting point happens after deposition, when interaction of the deposited material and gas-phase species forms low-melting-point phases. Sintering develops over time as low-viscosity material flows and fills the pores of a deposit. Decreasing the numbers or size of the pores in the deposit increases strength. The larger the quantity of the liquid phase, the higher the potential for sintering and generating hard deposits.

Sulfate-based sintering is attributed to the filling of deposit pores by sulfation of the alkaline and alkaline-earth components in the deposit. Sulfates are generally unstable and decompose above $1850^{\circ} \mathrm{F}\left(1000^{\circ} \mathrm{C}\right)$, but form very rapidly at temperatures slightly below this decomposition temperature. The crossover temperature range from rapid sulfation to decomposition is narrow and can be crossed in some areas of the boiler as a result of load swings.

Both silicate- and sulfate-based strengths are determined for each deposit. The silicate strengths are a function of the viscosity and particle size of the deposited materials and the time duration of deposition. Equation 4 determines a silicate variable that is a function of the deposit potential, particle diameter, and particle viscosity.

$$
\mathrm{Sil}_{\mathrm{v}}=\mathrm{DP} \times \mathrm{D}_{\mathrm{p}} \times \mu_{\mathrm{p}}
$$


The silicate variable is summed for all of the particle-size bins for that particular deposit type. For example, using Equation 5, the silicate variable for a downstream deposit strength would sum the ash size bins less than 10 microns.

$$
\overline{\operatorname{Sil}_{\mathrm{v}}}=\frac{\Sigma \mathrm{Sil}_{\mathrm{v}}}{\Sigma \mathrm{DP}}
$$

The cumulative silicate variable is divided by the total deposit potential, producing a weighted average silicate variable. The average silicate variable is the unitless time needed to achieve a completely sintered deposit. The silicate strength of the deposit at that time interval is determined using Equation 6.

$$
\operatorname{Str}_{\text {sil }}=1-\left(\frac{1}{(t+1)^{\overline{\text { sil }}_{v}}}\right)^{S_{r c}}
$$

The silicate strength is summed over all of the deposit layers present. The longer a deposit has time to sinter, the higher the silicate strength. The weighted average silicate strength ( $\left.\operatorname{Str}_{\text {sil }}\right)$, Equation 7, is the sum of each deposit layer strength multiplied by that deposit layer's respective mass, divided by the total deposit mass. The weighted average silicate strength is an index value, from 0 to 1 , with 1 being the maximum silicate strength.

$$
\overline{\mathrm{Str}_{\text {sil }}}=\frac{\Sigma\left(\mathrm{Str}_{\text {sil }} \times \mathrm{M}_{\mathrm{L}}\right)}{\mathrm{M}_{\mathrm{dep}}}
$$

The sulfate strength, Equation 8, is a function of composition and is assumed to reach maximum strength immediately. The PC factors 1 and 2 in the equation are calibration numbers the EERC has obtained from previous projects. Sulfation strengths are set to zero if the temperature is above the sulfate decomposition temperature.

$$
\mathrm{Str}_{\text {sulf }}=\frac{\frac{\mathrm{Na}_{2} \mathrm{O}+\mathrm{MgO}+\mathrm{K}_{2} \mathrm{O}+\mathrm{CaO}}{\mathrm{Si}_{2} \mathrm{O}} \times \mathrm{PCF}_{1}-\mathrm{PCF}_{2}}{\mathrm{C}_{\text {sulf }}}
$$

The sulfate strength is divided by a constant to produce a sulfate strength index number, from 0 to 1 . Both sulfate and silicate strength mechanisms can occur at the same location. Figure 9-4 shows how the sulfate and silicate strength curves may intersect. The greatest strength determined from the two functions is chosen as the strength for that deposit layer $\left(\mathrm{Str}_{\mathrm{depl}}\right)$ at that time interval. An average deposit strength $\left(\mathrm{Str}_{\text {depavg }}\right)$ can be determined by summing the strength multiplied by the deposit layer mass and divided by the total deposit mass. 


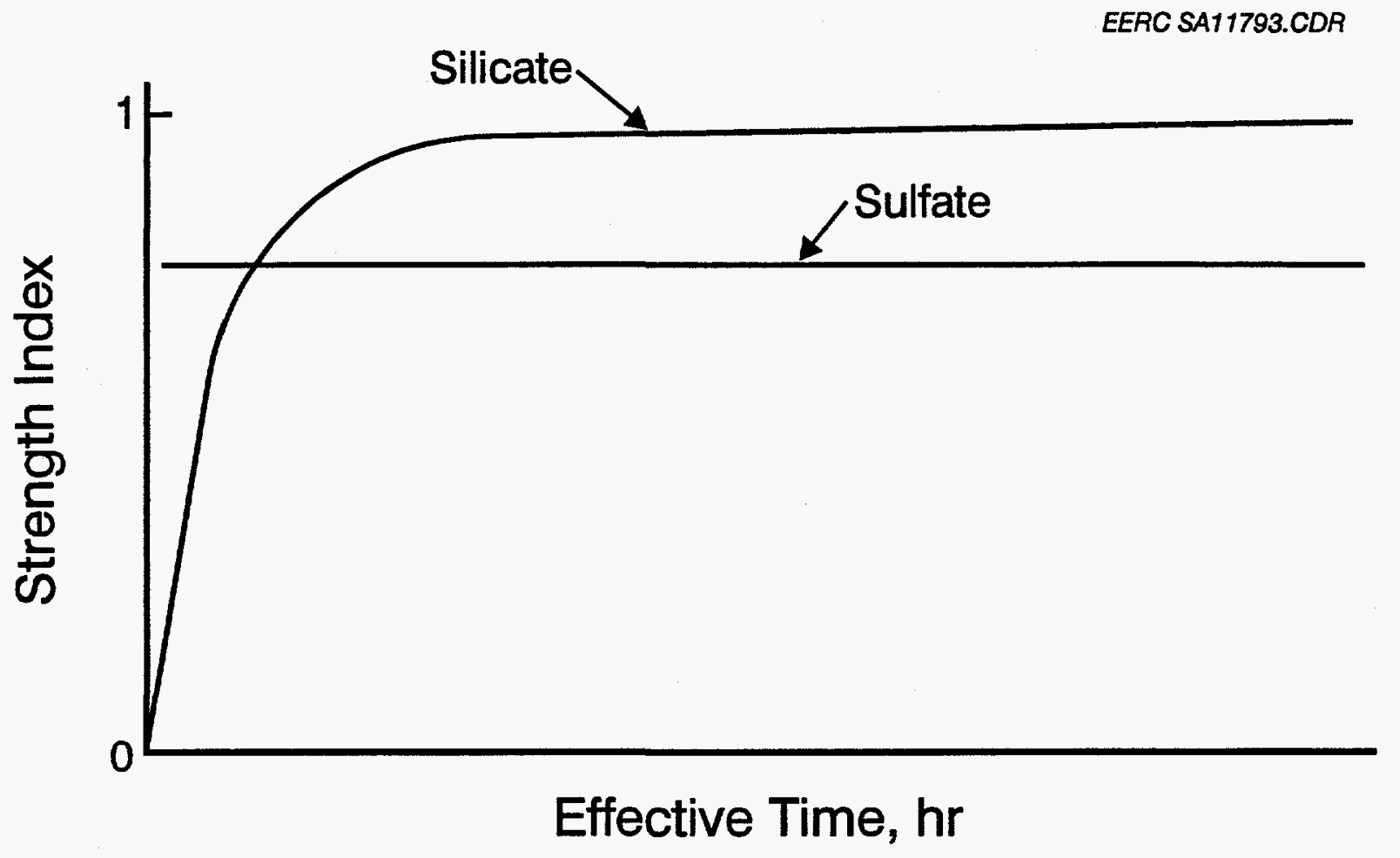

Figure 9-4. Strength development curve.

\subsubsection{Thermal Properties}

The thermal properties submodel is a collection of functions that support the other submodels. The thermal properties of the deposits depend upon the thickness, temperature, and physical sintered state of the deposit. Because of the changing temperature and sintered state throughout the thickness of a deposit, as well as its growth and removal, the thermal properties are not constant and require multiple iterations throughout the running of the FOULER model. Since the deposition rates and compositions of the upstream and downstream deposit are different, the thermal property calculations are considered separately for each half of the heatexchange tube.

The main thermal property submodel is the heat-transfer function, which is responsible for the determination of the heat-transfer value through the deposit. The change in heat transfer is due to the convection and conduction through the gas stream, deposit, tube, and steam. Figure 9-5 shows the components of the heat-transfer function, along with a relative temperature drop through an upstream deposit. The forced convection heat-transfer rate, $q$ " conv, occurs at the boundary layer between the gas stream and the deposit surface. The forced convection value is dependent upon surface geometry and flow conditions and several fluid properties, which include density, viscosity, thermal conductivity, and specific heat. The thermal property submodel contains several fluid property functions, which are documented in the FOULER code. Once the fluid parameters are determined, a subfunction determines 


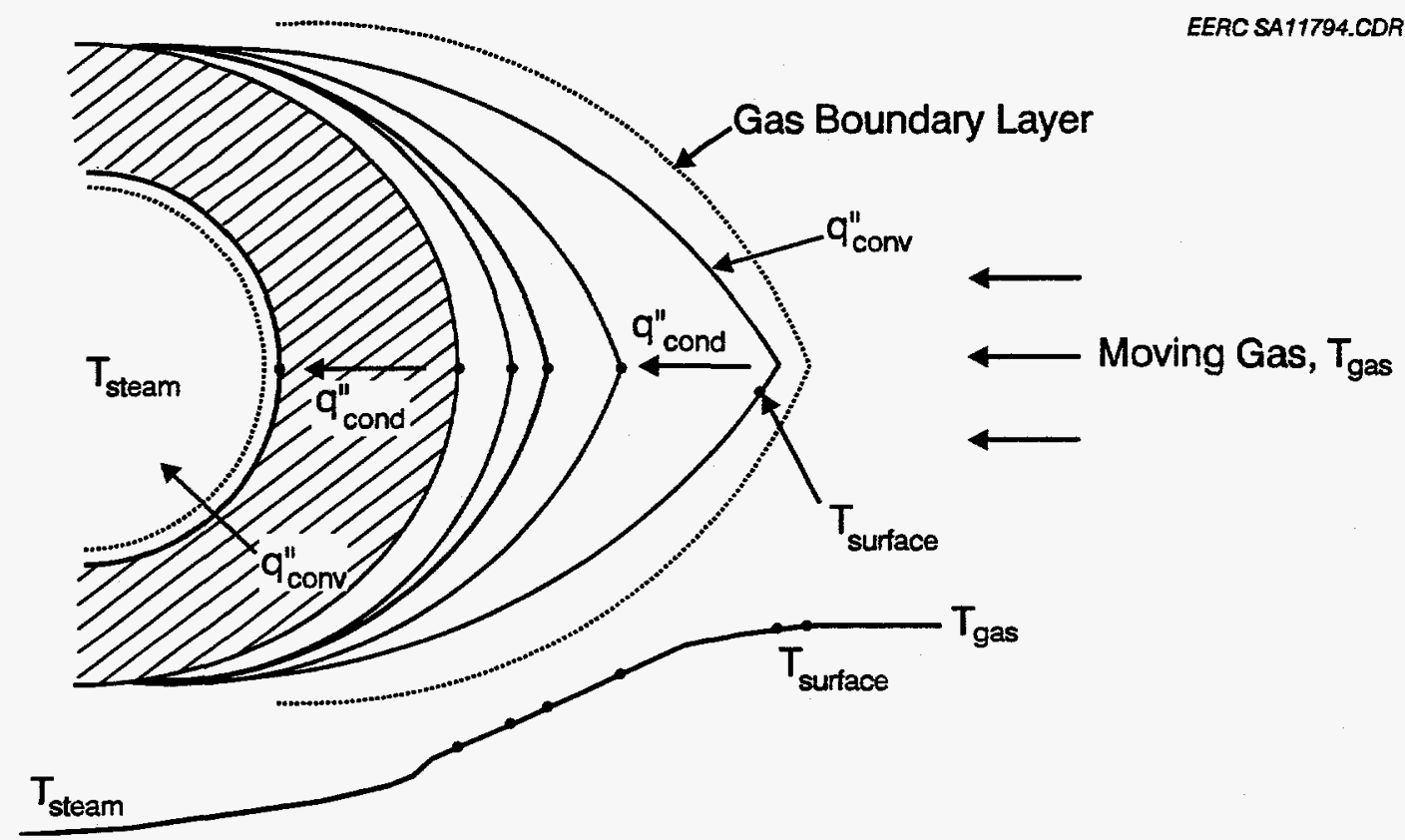

Figure 9-5. Heat transfer through deposit.

whether the flow at the boundary layer is turbulent or laminar. Depending upon the flow characteristics and average convection coefficient, $h_{\text {conv }}, q^{\prime \prime}$ conv is determined. The conductive heat-transfer rate, $\mathrm{q}^{\prime \prime}$ cond, through the deposit and tube is dependent upon thermal conductivity, temperature, and thickness of each layer. Determination at the convection heat-transfer rate through the steam is similar to solving the forced convection of the gas stream. The heat equation for the heat transfer through the deposit is given in Equation 9.

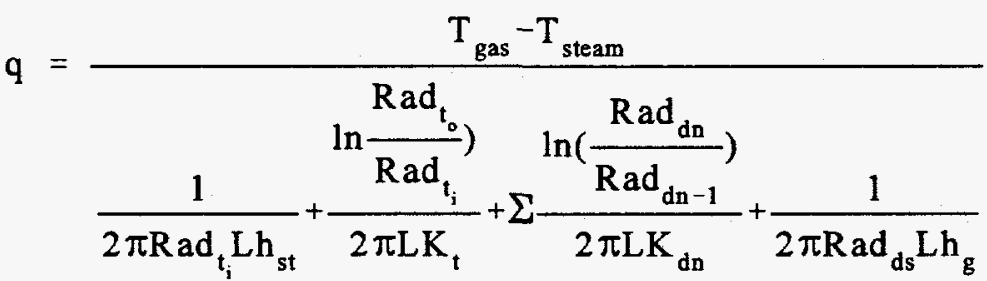

The deposit thermal conductivity is based on laboratory measurements of ash thermal conductivity. The conductivity of ash is nearly independent of the chemical composition, but is strongly dependent on the degree of sintering. Further, the ash conductivity exhibits hysteresis: once heated to a point where sintering occurs, the ash on cooling has a higher thermal conductivity than the original unsintered ash.

\subsubsection{Deposit Removal}

The deposit removal algorithm accounts for thermal shedding, sootblowing, and gravity shedding. The removal characteristics of the deposit are calculated based on the deposit growth 
and strength development. The removal indices have a value from 0 to 1 , with 1 being complete removal. The sootblowing and load drop models are applied only at the time intervals supplied by the input data. The largest removal index is selected for each time interval.

Thermal shedding occurs when a utility drops load, resulting in a temperature change in the boiler. Because of the different thermal expansion value of the ash deposit and the steam tube, the result is shear fracture in the deposit. The difference in thermal expansion can be correlated to the density of the deposit. The change in temperature and the strength of the deposit are the main variables in determining the thermal-shedding index.

Gravity shedding is common in the backpass regions of a utility boiler where strength development is low, but deposition is high. This form of deposit removal is correlated to the strength:mass ratio of the deposit. The gravity-shedding index is a function of the deposit strength and weight. Unlike load shedding and sootblowing, gravity shedding is possible at every time interval, since shedding occurs as the weight of the deposit becomes greater than the strength.

The amount of removal due to sootblowing is calculated by comparing the strength of the deposit with the shear stress applied to the deposit by a retractable sootblower as a function of the blowing medium, pressure, nozzle angle, and spacing between sootblowers.

\subsection{Fouling Algorithms Results}

The fouling algorithms have been tested in other projects for pc utility boilers. A great deal of experimentation, sampling, and analysis on full-scale and pilot-scale tests has been conducted. The predicted results have compare well with the experimentally measured and fullscale sampling results. The FBC project has not had the ability to allow the same extensive testing for a fluidized bed, but the same underlying deposition, strength, thermal, and deposit removal algorithms are expected to hold true.

Comparsions of upstream and downstream deposit strengths for a Beulah lignite, using the Heskett boiler configuration, with and without a limestone sorbent, are shown in Figure 9-6. As expected, the deposits with a sorbent added for sulfur capture show a higher deposit strength. The downstream deposits show a higher strength than the upstream deposits in both sorbent and no sorbent cases. These results match the stronger downstream deposits that were observed in the EERC's pilot-scale CFBC.

The sorbent increased the upstream and downstream deposit mass as shown in Figure 9-7, except for the upstream deposit in the economizer with no sorbent added. The limestone additive may have masked or diluted the sodium in the Beulah lignite, thus lowering the deposition rate, but once the sorbent was removed, the sodium may have had a greater effect in raising the upstream deposition rate. The fouling algorithms, using the same coal, have shown a lower deposition rate $(0.1-0.5)$ for the FBC configuration when compared to a pc-fired configuration (0.6-1.2).

The Beulah lignite coal has a higher deposit mass (Figure 9-8) compared to the two bituminous coals under the same operational conditions. A greater difference was expected 


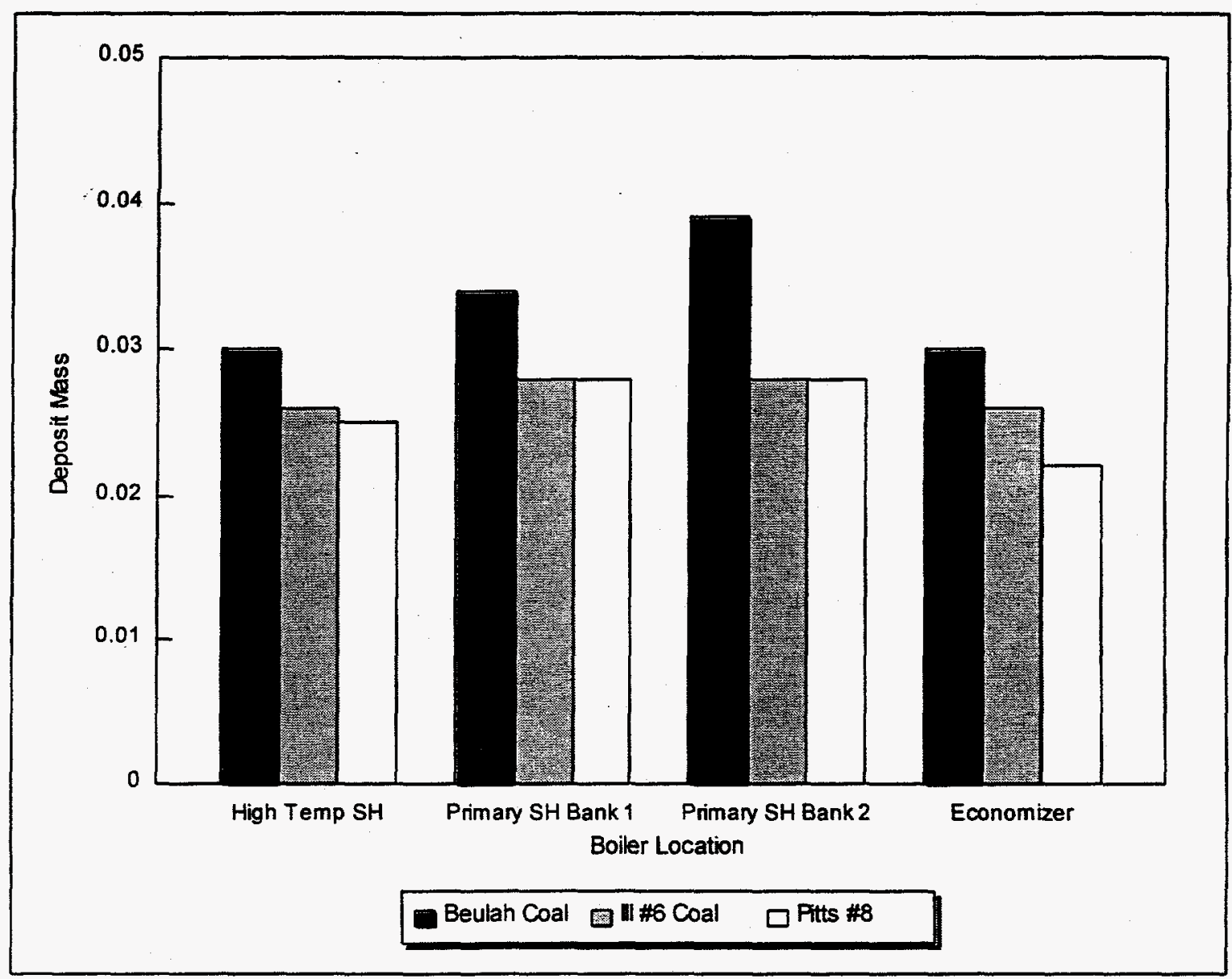

Figure 9-6. Comparison of upstream and downstream deposit strengths of a Beulah lignite with limestone sorbent added and a Beulah lignite with no sorbent added.

between the lignite and bituminous coals. It is anticipated that how the model accounts for the addition of sorbent may give higher-than-expected deposition rates for these coals. As stated earlier, the model predicts that the sorbent will have the same size distribution as the coal. The coal ash distribution probably has a greater percentage of fines than the limestone. The model also predicts that the finer particles will have a greater impact on deposit growth and strength formation. By predicting a fine distribution of limestone, the deposition rate may therefore be overpredicted. More work is recommended in the area of size and its impact on deposition rate.

The addition of a limestone sorbent to Beulah lignite has lowered the sootblower effectiveness using the Heskett boiler data file, as expected (Figure 9-9). This is due to the increased deposit strength and mass seen with the addition of the limestone. 


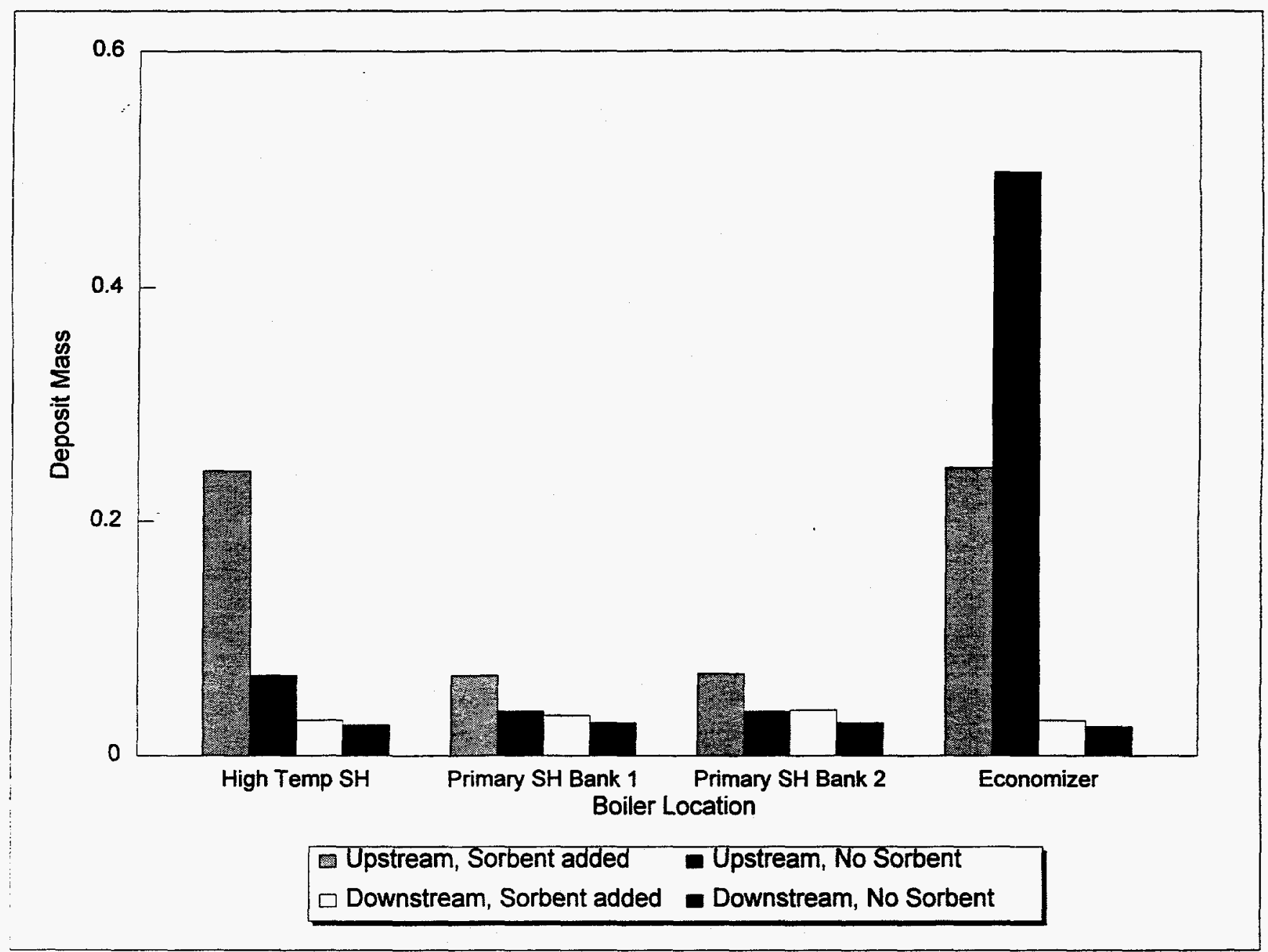

Figure 9-7. Comparison of upstream and downstream deposit masses for a Beulah lignite fired with and without a limestone sorbent. 


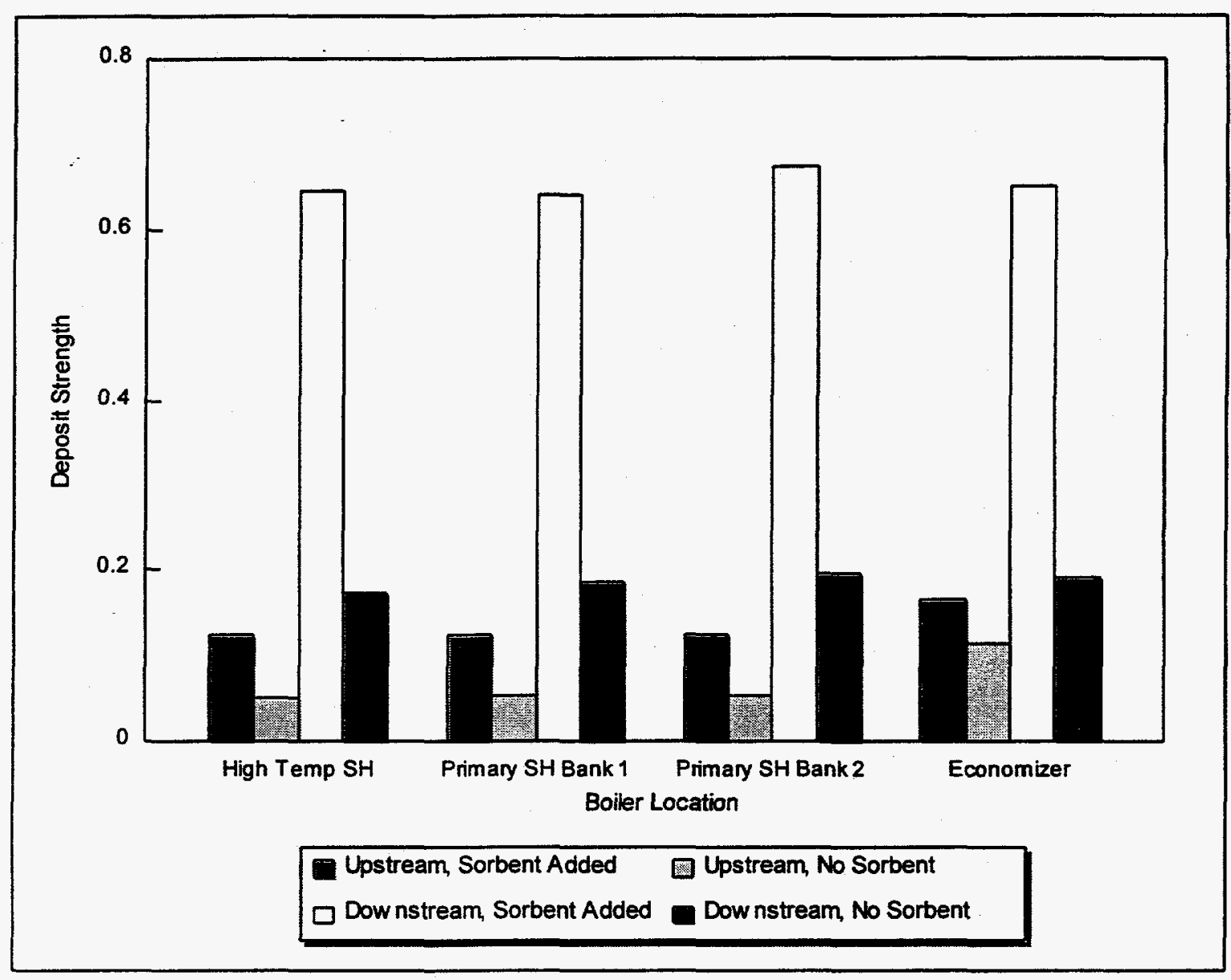

Figure 9-8. Comparison of downstream deposit strength for three coals with a sorbent additive using the Heskett boiler configuration. 


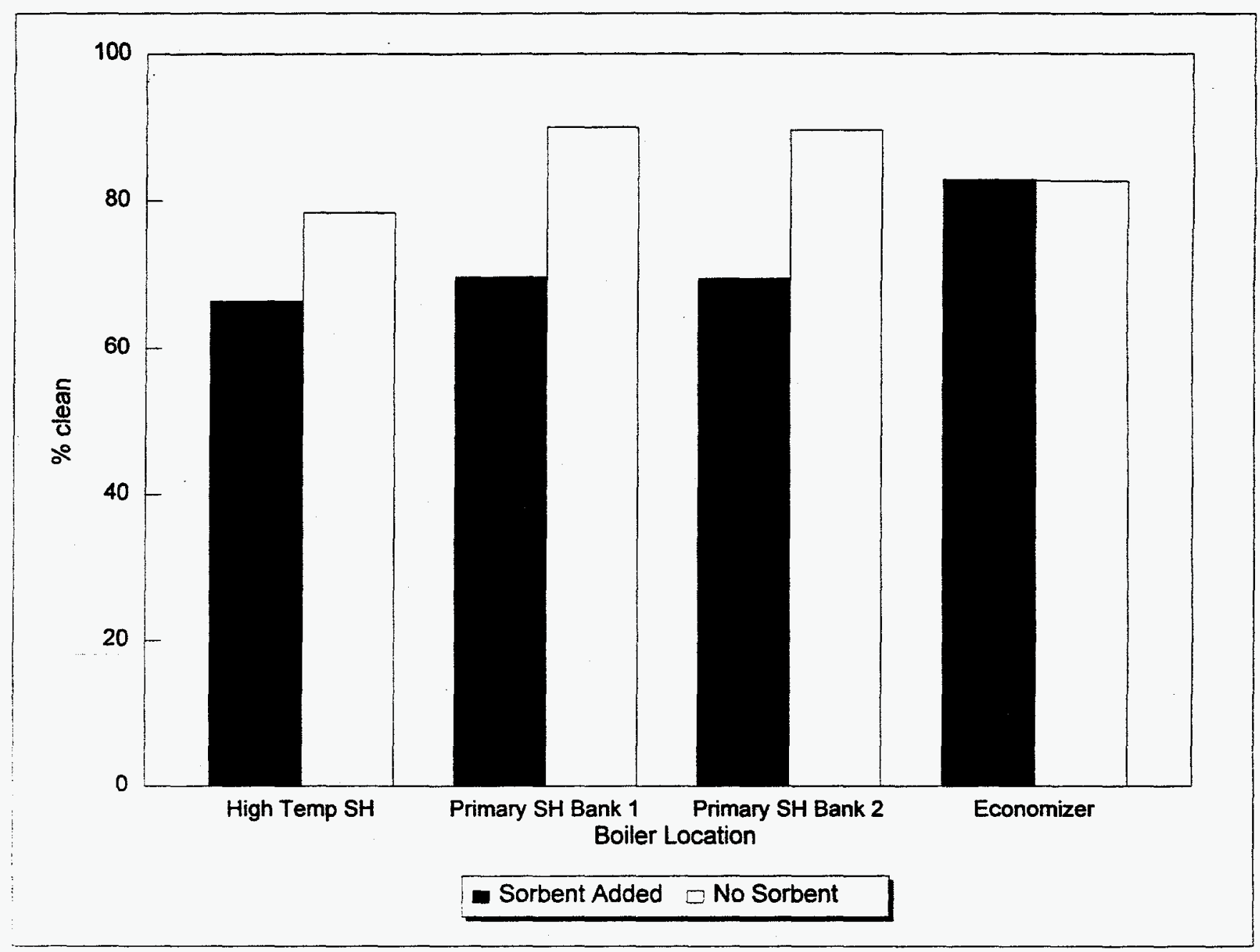

Figure 9-9. Comparison of sootblower effectiveness for Beulah lignite using the Heskett boiler configuration. 
10.0

CONCLUSIONS 


\subsection{CONCLUSIONS}

The successful design and operation of the FBC requires the ability to control and mitigate ash-related problems. The major ash-related problems in fluidized-bed combustion are agglomeration of bed material and ash deposition on heat-transfer surfaces, ash deposition on refractory and uncooled surfaces, corrosion, and erosion. The focus of this program was on the agglomeration and deposition problems in atmospheric bubbling and circulating beds. This three-year, multiclient program focused on the behavior of inorganic components in FBC using advanced methods of analysis of full-scale samples coupled with bench-scale experience. The major conclusions and recommendations are highlighted below.

\subsection{Agglomeration}

- Agglomerates can be classified into four distinct categories: bed particles "glued" together by coal ash, hollow eggs, sintered fly ash, and high-temperature agglomerates, each having different mechanisms of formation.

- For the glued agglomerates formed when burning high-alkali (sodium and potassium) fuels, the mechanisms of adherence and growth appear to be via a molten sulfate matrix through the fluxing action of sodium with the calcium sulfate matrix.

- For glued agglomerates, there is a definite interaction between bed material and ash, with materials high in available silica contributing more to agglomeration than others.

- Sintered agglomerates tend to form from fine-grained calcium particles. Other elements, such as sodium and potassium and, possibly, vanadium, act as a flux to increase the sinter rate and the propensity to form agglomerates. Sulfation and sintering of this material over time provide strength.

- Egg-type agglomerates form around large coal particles that go through a plastic deformation stage during combustion. Bed particles stick to the coal surface, and the coal burns out, leaving a hollow shell.

- High-temperature agglomerates form primarily during upset conditions and were not the focus of this study.

- Factors that enhance the formation of agglomerates include local reducing conditions in the bed; high temperature, particularly on the surface of the coal particles, which approach the melting temperatures of various mineral phases; increased pressure which speeds reaction rates as a result of increased partial pressures of oxygen; and the presence of a fluxing agent such as sodium or potassium.

- The bench-scale PFBR was found to mimic the chemistry of the full-scale units.

- The PFBR can effectively predict the tendency of fuel, bed material, and/or sorbent to form agglomerates. 
- A computer code called FBCSUL was developed to predict the tendency of a fuel to agglomerate as a function of temperature, using an SEMPC analysis of ash generated from burning the fuel and sorbent. ASTM ash of a mixture of fuel and sorbent can be used with some loss of accuracy.

- Although higher temperatures tend to favor the formation of agglomerates, there exists a temperature window between $1550^{\circ}$ and $1650^{\circ} \mathrm{F}$ where agglomeration is minimized.

- Injection of limestone into a silica bed does reduce the tendency of the bed material to agglomerate.

- Bed materials low in available silica are less likely to agglomerate. Examples of suitable bed materials include gabbro, olivine sand, and feldspars.

- Additives such as kaolin and other clays that react to tie up the alkali are effective in controlling agglomeration.

- Egg formation could be reduced or eliminated by finer sizing of the feed coal.

- Reduction and/or modification of the sodium in the coal by selective mining, blending, and/or ion exchange has been shown to be effective in reducing agglomeration.

\subsection{Deposition}

- Ash deposition on heat-transfer surfaces, refractory, and uncooled surfaces in the FBC is primarily caused by fine-grained calcium particles derived from either the coal or limestone.

- A mechanism for deposition has been presented, based on solid-state sintering of calcium sulfate. Sodium and potassium increase fouling rates and strength development.

- A computer code called FBCDEP was developed to provide relative indices of deposition rate, strength value, and deposit thermal resistance for upstream and downstream deposits and sootblower effectiveness. The impacts of both fuel properties and boiler design can be modeled.

- Load shedding and sootblowing appear to be effective methods of reducing fouling tendencies.

- Coals with high iron contents in the ash may cause some ash-related problems; however, these were not investigated as a part of this project. 
11.0

\section{CONCLUSIONS}




\subsection{REFERENCES}

Conn, R.E.; Austin, L.G. "Studies of Sintering of Coal Ash Relevant to Pulverized Coal Utility Boilers: 1. Examination of the Raask Shrinkage-Electrical resistance Method," Fuel 1984, 1664-1670.

Henderson, A.K.; Moe, T.A.; Hajicek, D.R. "Design and Operations of the EERC Pilot-Scale Circulating Fluidized-Bed Combustor," In Proceedings of the 16th Biennial Low-Rank Fuels Symposium; Billings, MT, 1991; pp 407-420.

Jones M.L.; Kalmanovitch, D.P; Steadman E.N.; Zygarlicke C.J.; Benson, S.A. "Applications of SEM Techniques to the Characterization of Coal and Coal Ash Products, " in Advances in Coal Spectroscopy; Meuzelarr, M.L.C., Ed.; Plenum Publishing Co.: New York; 1992.

Mann, M.D. "Fluidized Bed Combustion," Low-Rank Coal Combustion, Work Performed Under Cooperative Agreement No. DE-FC-83FE60181, DOE/UNDEERC/QRT-85/3-4, May 1986.

Moe, T.A.; Mann, M.D.; Henderson, A.K.; Hajicek, D.R. "Pilot-Scale CFBC Systems: A Valuable Tool for Design and Permitting," In Proceedings of the 4th International Conference on Circulating Fluid Beds; Somerset, PA, 1993.

Nagarajan, R.; Anderson, R.J. "Effect of Coal Constituents on the Liquid-Assisted Capture of Impacting Ash Particles in Direct Coal-Fired Gas Turbines," ASME Paper No. 88-GT-192, 1988.

Zygarlicke, C.J.; McCollor, D.P.; Galbreath, K.C. "Development of Fireside Performance Indices," final report; EERC publication, July 1995.

Zygarlicke C.J.; Steadman E.N. "Advanced SEM Techniques to Characterize Coal Minerals," Scanning Electron Microscopy 1990, 4 (3), 579-590. 